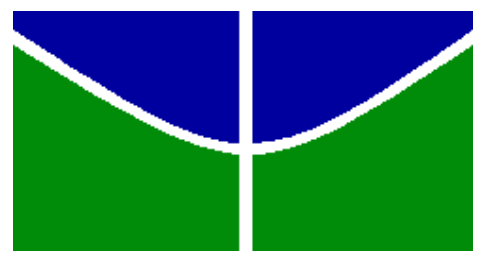

Universidade de Brasília

Instituto de Psicologia

Programa de Pós-Graduação em Psicologia Social, do Trabalho e das Organizações

A INFLUÊNCIA DOS VALORES HUMANOS INDIVIDUAIS E DA ATITUDE FRENTE À ARMA DE FOGO NO MEDO DO CRIME: ESTUDO COMPARATIVO DE UMA REGIÃO ADMINISTRATIVA DO DISTRITO FEDERAL

Francisco Guilherme Lima Macedo

Brasília, 2017 


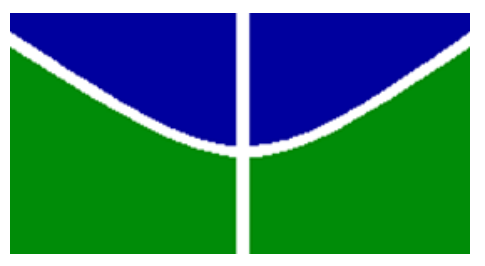

Universidade de Brasília

Instituto de Psicologia

Programa de Pós-Graduação em Psicologia Social, do Trabalho e das Organizações

\section{A INFLUÊNCIA DOS VALORES HUMANOS INDIVIDUAIS E DA ATITUDE FRENTE À ARMA DE FOGO NO MEDO DO CRIME: ESTUDO COMPARATIVO DE UMA REGIÃO ADMINISTRATIVA DO DISTRITO FEDERAL}

Francisco Guilherme Lima Macedo

Dissertação apresentada ao Instituto de Psicologia da Universidade de Brasília, como requisito parcial à obtenção do título de Mestre em Psicologia Social, do Trabalho e das Organizações.

Orientação: Prof. Dr. Cláudio Vaz Torres 
Universidade de Brasília

Instituto de Psicologia

Programa de Pós-Graduação em Psicologia Social, do Trabalho e das Organizações

DISSERTAÇÃO SUBMETIDA À SEGUINTE BANCA EXAMINADORA:

Prof. Dr. Cláudio Vaz Torres - Orientador

Programa de Pós-graduação em Psicologia Social, do Trabalho e das Organizações

Universidade de Brasília - UnB

Profa. Dra. Ana Lúcia Galinkin - Membro Interno

Programa de Pós-graduação em Psicologia Social, do Trabalho e das Organizações Universidade de Brasília - UnB

Prof. Dr. Thiago Gomes Nascimento - Membro Externo Programa de Pós-graduação em Gestão Estratégica de Organizações

Centro Universitário de Ensino Superior de Brasília - IESB

Profa. Dra. Elaine Rabelo Neiva - Suplente

Programa de Pós-graduação em Psicologia Social, do Trabalho e das Organizações Universidade de Brasília - UnB

Brasília, 2017 


\section{Agradecimentos}

Esta dissertação, como a maior parte dos trabalhos desenvolvidos em minha vida (senão todos) é antes de tudo um produto coletivo, com diversas mãos e colaborações que tornaram este resultado possível.

Primeiramente agradeço a Deus, Aquele que me permitiu chegar a este momento, enfrentando todas as dificuldades e pacientemente me conduzindo por seus caminhos sábios e de realização, além de encaminhar pessoas que pudessem me apoiar nessa caminhada, não só agora mas ao longo de toda a minha existência.

À Adriana Lira, minha amada esposa e mãe do meu amado filho Renato Miguel, que me apoio irrestritamente e sonhou comigo os sonhos mais altos, acreditando em meu desenvolvimento pessoal e profissional, e sem a qual eu certamente não teria chegado a esta sonhada conquista. Obrigado pelo amor, pelo exemplo, em resumo, obrigado por tudo. Te amo.

Ao meu filho, Renato Miguel, por iluminar meus dias e me fazer sentir um amor jamais experimentado antes. Obrigado meu filho.

Aos meus pais, Macedo e Francisca, pelos ensinamentos que desde a tenra idade conduziram-me pelo caminho dos valores que guiaram os meus passos ao longo de toda a minha caminhada. Obrigado pelo amor incondicional.

Agradeço ao meu orientador, Cláudio Torres, não só por ter sido fundamental em todo esse processo, com suas sábias palavras sobre o conteúdo desta dissertação, com seus conselhos pessoais e profissionais e pelo exemplo de profissionalismo, dedicação e humildade, demonstrando na prática os pilares de um verdadeiro professor e mestre. 
Aos membros de minha banca de dissertação: Prof. Dr. Cláudio Vaz Torres, Profa. Dra. Ana Lúcia Galinkin e Prof. Dr. Thiago Gomes Nascimento. Suas contribuições foram imprescindíveis para o resultado deste trabalho. Muito Obrigado!

Agradeço à minha família, representando pelo meu irmão Glauber, e à família da minha esposa, representada pelo Sr. Eugênio e pela D. Ailza, tanto pelo apoio, pelos conselhos e pelo estímulo nesse e em outros desafios Aos dois últimos, meu agradecimento especial pelo exemplo de proteção, cuidado e amor pela família.

Agradeço aos amigos que me apoiaram bastante ao longo do mestrado e que foram muito importantes antes mesmo dessa caminhada ser iniciada. À Sueli Menelau, que participou ativamente ao longo de todo o processo, sendo crucial com sugestões, colaborações, visão do processo e com conselhos pessoais e profissionais determinantes. Obrigado pela sua amizade de sempre. Ao Thiago Gomes, que também foi essencial em momentos importantes dessa dissertação, ao longo de todo o trabalho. Obrigado pelo apoio. Ao Breno Adaid-Castro, pela precisão nos ensinamentos e pela paciência de sempre.

À colaboração essencial de Andréia Lira, na fase de coleta de dados, e de Zaniscke, na tabulação destes, as quais facilitaram bastante uma parte essencial e complexa do trabalho de pesquisa. Não tenho como agradecê-las.

Por fim, agradeço a todos os amigos que eu trouxe de antes do mestrado e que fiz ao longo dessa caminhada, os quais prefiro não nomear para não correr o risco de ser minimamente injusto. Obrigado pela presença, mesmo na distância, e por realizarem este papel nobre de maneira tão completa. 


\section{Resumo}

Este estudo teve por finalidade definir como os Valores Humanos Individuais e a Atitude Frente à Arma de Fogo influenciam o Medo do Crime em uma Região Administrativa do Distrito Federal. O medo do crime constitui-se em um fenômeno multidimensional, constituído pelas muitas possibilidades de reação diante de situações definidas como perigosas, bem como da própria representação do que seria uma ameaça, situando-se em uma fase de maturação teórica e empírica, em que pese já ser estudado há algumas décadas em outros países, tornando a utilização de outras variáveis imprescindível para um entendimento mais completo deste objeto de estudo, destacando-se neste contexto os Valores Humanos Individuais e a Atitude Frente à Arma de Fogo. Para atender a esse propósito, 834 respondentes residentes na Região Administrativa de Ceilândia preencheram um questionário com 3 escalas, Medo do Crime (EMC), Portrait Values Questionnaire Revised (PVQ-R) (Schwartz et al., 2012) e a Escala de Atitude Frente à Arma de Fogo (Nascimento, Pimentel \& Adaid-Castro, 2016). Dos respondentes, 414 são representantes da população em geral média de 32,26 anos $(\mathrm{dp}=0,50)$, com $55,8 \%$ de mulheres, $51,0 \%$ de solteiros, $78,2 \%$ com ensino fundamental ou médio - e 420 são estudantes universitários - média de 26,03 anos $(\mathrm{dp}=7,09), 54 \%$ de mulheres, $67,6 \%$ solteiros, e $100 \%$ de graduandos ou graduados. Os resultados indicaram uma predição entre Valores Humanos Individuais e Medo do Crime, e entre aqueles e Atitude Frente à Arma de Fogo, não sendo constatada tal relação entre Atitude Frente à Arma de Fogo e Medo do Crime, o que descartou a possibilidade de mediação, por parte da Atitude Frente à Arma de Fogo, entre Valores Humanos Individuais e Medo do Crime. Foram observadas relações significativas entre Medo do Crime e os tipos motivacionais de $2^{\mathrm{a}}$ ordem dos Valores Humanos Individuais, com relações positivas entre aquele e os tipos de conservação e autotranscendência, e negativa entre aquele e o tipo de abertura à mudança. Com relação à Atitude Frente à Arma de Fogo e os Valores Humanos Individuais, foram encontradas relações significativas entre aquela e os tipos motivacionais de conservação e autopromoção, em sentidos inversos, demonstrando que existem restrições dos indivíduos à arma de fogo, sendo esta ligada a panoramas negativos de violência índices criminais, acidentes e incidentes com mortes, entre outros - e ao próprio cenário de limitação de acesso legal a estas (Silva \& Beato Filho, 2013). Na relação entre Medo do Crime e a Atitude Frente à Arma de Fogo, mesmo não encontrando resultados significativos em nenhuma das amostras entre as variáveis, foram verificadas na amostra 2 associações significativas entre medo do crime e os três fatores da atitude frente à arma de fogo, direitos, crime e proteção. Não foram encontradas diferenças significativas entre as amostras com relação ao medo do crime e, como resultado secundário, obteve-se predição entre sexo e medo do crime, com diferenças significativas entre os sexos e maiores níveis de medo para as mulheres. Como limitações da pesquisa foram verificados: a utilização do autorelato; a ausência de outras variáveis atitudinais, de normas sociais, e outras que possam auxiliar no aprimoramento da pesquisa. Como agenda de pesquisa sugere-se o aprimoramento da medida de medo do crime, com a construção qualitativa de novos itens para medo do crime; a coleta em outras regiões do DF e em outras unidades federativas; e, a inclusão de outras variáveis mediadoras e moderadores na relação entre Valores Humanos e Medo do Crime.

Palavras-chave: Medo do Crime; Valores Humanos; Atitude Frente à Arma de Fogo. 


\begin{abstract}
The mains purpose of this research was to define how Individual Human Values and Attitude toward Guns influence the Fear of Crime in an Administrative Region of the Distrito Federal. The fear of crime is a multidimensional phenomenon, constituted by the many possibilities of reaction to situations defined as dangerous, as well as the representation of what would be a threat, and is in a theoretical and empirical maturation phase, despite being studied a few decades ago in other countries, being essential use of other variables for a more complete understanding of this object of study, highlighting in this context Individual Human Values and Attitude toward Guns. To achieve this objective, 834 respondents residing in the Administrative Region of Ceilandia completed a questionnaire with 3 scales, Fear of Crime (FCS), Portrait Values Questionnaire Revised (PVQ-R) (Schwartz et al., 2012) and the Attitude Toward Guns (Nascimento, Pimentel \& Adaid-Castro, 2016). Of the respondents, 414 are representatives of the general population $-M=32.26$ years $(\mathrm{DP}=0.50), 55.8 \%$ of women, $51.0 \%$ of unmarried, $78.2 \%$ with elementary or middle school - and 420 are university students $-M=26.03$ years $(\mathrm{SD}=7.09), 54 \%$ of women, $67.6 \%$ singles, and $100 \%$ of graduating students or graduates. The results indicated a prediction between Individual Human Values and Fear of Crime, and between those and Attitude to the Firearm, not being found such a relationship between Attitude Against the Firearm and Fear of Crime, which ruled out the possibility of mediation, by the Attitude toward Guns, between Individual Human Values and Fear of Crime. Significant relationships between Fear of Crime and the second-order motivational types of Individual Human Values were observed, with positive relations between it and types of conservation and self-transcendence, and negative relationships between it and the type of openness to change. Regarding the Attitude toward Guns and the Individual Human Values, significant relationships were found between it and the motivational types of conservation and self-interest, in opposite directions, demonstrating that there are restrictions of the individuals to the guns, being this linked to panoramas criminal indices, accidents and incidents with deaths, among others - and to scenario of limiting legal access to these (Silva \& Beato Filho, 2013). In the relationship between Fear of Crime and Attitude toward Guns, even though no significant results were found in any of the samples among the variables, on the sample 2 were observed significant associations between fear of crime and the three factors of attitude toward guns, rights, crime and protection. No significant differences were found between the samples regarding fear of crime and, as a secondary result, prediction was obtained between sex and fear of crime, with significant differences between sexs and higher levels of fear for women. As limitations of the research were verified: the use of self report; the absence of other attitudinal variables, of social norms, and others constructs that may aid in the improvement of the research. As agenda it is suggested to improve the measure of fear of crime, with a qualitative construction of new items; the collection in other administration regions of the Distrito Federal and other Brazilian States; and the inclusion of other mediating and moderators variables in the relationship among Human Values and Fear of Crime.
\end{abstract}

Keywords: Fear of Crime; Human Values; Attitude Toward Guns. 


\section{Lista de Tabelas}

Tabela 1 Combinações C-A-M e estado atribuído

Tabela 2 Valores hipotetizados por Schwartz e Bislky, suportados pela teoria de Rokeach.71

Tabela 3 Relação dos Valores Humanos de Schwartz

Tabela 4 Os 19 Valores da Teoria Refinada, definidos em termos de Metas Motivacionais, e seus valores originários 77

Tabela 5 Homicídios por Arma de Fogo. UF e Região. 2004/2014* 99

Tabela 6 Taxas de homicídio (por 100 mil habitantes) por arma de fogo. UF e Região. $2000 / 2014 *$

Tabela 7 População das Regiões Administrativas do DF e Participação Percentual destas. $2011 / 2013 / 2016$ 108

Tabela 8 População das Regiões Administrativas vítima de violência. 2013 109

Tabela 9 Percentual de Habitantes com Curso Superior Completo 112

Tabela 10 Tipos motivacionais dos Valores Humanos no Brasil 114

Tabela 11 Distribuição dos dados sociodemográficos 126

Tabela 12 Autovalores empíricos e aleatórios da EMC (amostra 2)

Tabela 13 Matriz fatorial da EMC (amostra 1) 128

Tabela 14 Índices de estimação do modelo teórico da Escala de Medo do Crime 132

Tabela 15 Índices de estimação dos tipos motivacionais de $2^{\mathrm{a}}$ ordem da Teoria Refinada de Valores de Schwartz 134

Tabela 16 Índices de estimação da Escala de Atitude Frente à Arma de Fogo 137

Tabela 17 Descrição das siglas dos constructos e variáveis utilizadas. 138

Tabela 18 Correlações entre medo do crime, valores individuais (conservação) e atitude frente à arma de fogo (amostra 1).

Tabela 19 Correlações entre medo do crime, valores individuais (conservação) e atitude frente à arma de fogo (amostra 2). 141

Tabela 20 Correlações entre medo do crime, valores individuais (autotranscendência) e atitude frente à arma de fogo (amostra 1).....

Tabela 21 Correlações entre medo do crime, valores individuais (autotranscendência) e atitude frente à arma de fogo (amostra 2).

Tabela 22 Correlações entre medo do crime, valores individuais (autopromoção) e atitude frente à arma de fogo (amostra 1). 
Tabela 23 Correlações entre medo do crime, valores individuais (autopromoção) e atitude frente à arma de fogo (amostra 2).

Tabela 24 Correlações entre medo do crime, valores individuais (abertura à mudança) e atitude frente à arma de fogo (amostra 1). 146

Tabela 25 Correlações entre medo do crime, valores individuais (abertura à mudança) e atitude frente à arma de fogo (amostra 2) 147

Tabela 26 Correlações entre medo do crime, valores individuais e atitude frente à arma de fogo (fatores de $1^{\mathrm{a}}$ e $2^{\mathrm{a}}$ ordem, amostra 1). 148

Tabela 27 Correlações entre medo do crime, valores individuais e atitude frente à arma de fogo (fatores de $1^{\mathrm{a}}$ e $2^{\mathrm{a}}$ ordem, amostra 2 ) 148

Tabela 28 Regressões realizadas para a amostra 1 151

Tabela 29 Regressões realizadas para a amostra 2 153

Tabela 30 Regressões realizadas para variáveis sociodemográficas 155

Tabela 31 Testes-t para o Medo do Crime comparando amostras da população em geral e de estudantes universitários, todos residentes da Ceilândia 156

Tabela 32 Testes-t para o Medo do Crime comparando amostras de sexo 156 


\section{Lista de Figuras}

Figura 1 Representações alternativas das relações estruturais entre os domínios de valores

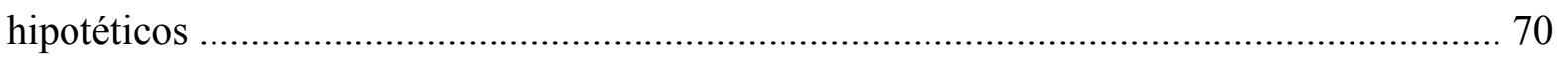

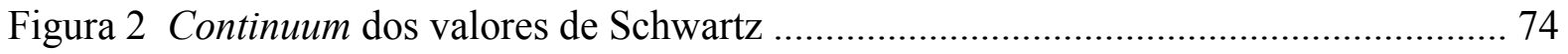

Figura 3 Continuum dos valores refinados de Schwartz ..................................................... 79

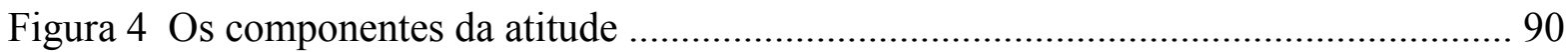

Figura 5 Vítimas de Homicídio por Arma de Fogo. Brasil (1980/2014*) .......................... 99

Figura 6 Estrutura fatorial da Escala do Medo do Crime (EMC) .................................... 133 


\section{Sumário}

1. Introdução 13

$\begin{array}{ll}1.1 \text { Pergunta de Pesquisa } & 16\end{array}$

$\begin{array}{ll}1.2 \text { Objetivo do Estudo } & 17\end{array}$

$\begin{array}{ll}\text { 1.2.1 Objetivo geral } & 17\end{array}$

$\begin{array}{ll}\text { 1.2.2. Objetivos específicos } & 17\end{array}$

2. Referencial Teórico 19

2.1 Medo do Crime: Análise do Construto 19

$\begin{array}{ll}2.1 .1 \text { Breve introdução ao tema } & 19\end{array}$

2.2 Definição do Construto 21

2.3 Histórico de Delineamento do Construto 25

$2.4 \mathrm{O}$ "Surgimento" do Construto 28

2.5 Segmentação Teórica 33

2.5.1. Vitimização direta 34

2.5.2. Vitimização imaginada e Psicologia do Risco 37

2.5.3. Percepção Ambiental 40

2.5.4. Mudanças estruturais e influências (de nível macro) no medo 43

2.5.5. Conexão de ansiedades relacionadas ao crime com outros tipos de ansiedade 46

2.5.6. Outras classificações $\quad 50$

2.6 Valores Humanos Individuais $\quad 64$

2.6.1 Panorama histórico e conceitual $\quad 64$

2.7 Modelo Teórico dos Valores Humanos de Schwartz 67

2.8 Aplicação da Teoria Refinada de Valores de Schwartz $\quad 78$

2.9 Atitudes $\quad 82$

2.9.1 Contextualização histórica e conceituação 83

2.10 Atitudes e Valores (e Comportamentos) 90

2.11 Atitude Frente à Arma de Fogo 94

$\begin{array}{ll}2.11 .1 \text { Contexto Nacional } & 94\end{array}$

2.11.2 Contexto do Distrito Federal 97

2.12 Aplicação empírica $\quad 102$ 


\section{Método}

3.1 Escolhas Metodológicas de Investigação

3.1.1 Lócus da pesquisa

$\begin{array}{ll}\text { 3.1.2 Participantes da pesquisa } & 105\end{array}$

3.2 Instrumentos de Pesquisa (Escalas de cada variável) 105

3.2.1 Escala de Valores Humanos Individuais Refinada (PVQ-R) 108

3.2.2 Escala de Atitude Frente à Arma de Fogo (EAFAF) 111

$\begin{array}{ll}\text { 3.2.3 Escala de Medo do Crime } & 111\end{array}$

3.3 Procedimento de Coleta de Dados 112

3.4 Análise dos Dados 114

$\begin{array}{ll}\text { 4. Resultados } & 117\end{array}$

4.1 Apresentação das Amostras e Análises Preliminares 119

$\begin{array}{ll}4.2 \text { Análise descritiva } & 121\end{array}$

4.3 Evidências de Validade da Escala de Medo do Crime 121

4.3.1 Análise fatorial exploratória com Software SPSS Statistics 122

4.3.2 Análise fatorial confirmatória com Software AMOS 124

4.3.3 Análise confirmatória dos Valores Humanos Individuais 124

4.3.4 Análise confirmatória da Atitude Frente à Arma de Fogo 127

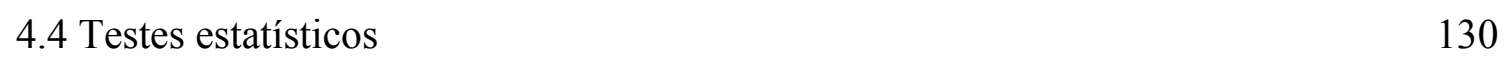

$\begin{array}{ll}\text { 4.4.1 Correlações } & 133\end{array}$

4.4.2 Regressões 134

$\begin{array}{ll}\text { 4.4.3 Teste de médias } & 135\end{array}$

$\begin{array}{ll}\text { 5. Discussão } & 147\end{array}$

Considerações Finais $\quad 152$

$\begin{array}{ll}\text { Referências } & 155\end{array}$

$\begin{array}{ll}\text { Anexo } & 163\end{array}$

166

191 


\section{Capítulo 1}

\section{Introdução}

Em anos recentes, a criminalidade e a violência urbanas têm se tornado objeto de debates e preocupação generalizada por parte dos mais diversos atores sociais (Silva \& Beato Filho, 2013). A questão tomou uma centralidade tal que não só lideranças e gestores públicos, mas os cidadãos como um todo preocupam-se cada vez mais aumento da incidência de criminalidade, aumento real de todas as modalidades de crimes e violências desde fins dos anos 1970, além de aparente falta de controle por parte do poder público (Frattari, 2013). Diante deste contexto, o sentimento de segurança pode ser visto como uma necessidade humana básica que precisa ser cumprida para permitir que os indivíduos realizem todo o seu potencial (Marmot, 2004).

Neste contexto, o medo na pesquisa das ciências sociais e aplicadas tornou-se uma área central de investigação, bem como um foco-chave da política criminal em todo o mundo (Brunton-Smith \& Sturgis, 2011). Reforça este posicionamento os investimentos cada vez maiores na área, no intuito primeiro de possibilitar que as ferramentas adequadas, tanto para prevenção quanto para a solução de crimes sejam alocadas e desenvolvidas (Langeani \& Pollachi, 2016). Apesar de sua relevância internacional e da evidência empírica descritiva de que os níveis médios de medo do crime variam de um país para outro (por exemplo, Semyonov, Gorodzeisky, \& Glikman, 2012; Ceobanu, 2010), e da existência de diversas pesquisas acerca do tema, estas se concentram em países de origem anglo-saxã (Hale, 1996; Jackson, 2009), concentram-se em ciências como a criminologia e a vitimologia (Ferraro, 1995), sendo considerado um constructo ainda em construção teórica e empírica (Farrall \& Gadd, 2004; Lee, 2011). 
Até o momento presente, essa investigação tem focado principalmente no exame de fatores que podem estar associados com o medo do crime de forma fragmentada, que se distinguem em relação aos diferentes níveis de análise que abordam - particularmente em termos individuais e coletivos - estando no cerne dos estudos individuais o exame de preditores e consequências do medo das pessoas contra o crime (Berenbaum, 2010) e os estudos coletivos, à forma de ocupação dos chamados "espaços sociais" (Bottoms, 2012, p. 455). Por outro lado, as hipóteses de vulnerabilidade lançam atenção à estipulação de fatores sociodemográficos como idade, gênero, etnia e deficiência física são preditores de medo do crime, uma vez que pessoas pertencentes a esses grupos sociais se sentem fisicamente ou socialmente vulneráveis (Rader, Cossman, \& Porter, 2012) e, portanto, com um maior risco de vitimização (ver, por exemplo, Pain, 2000). Outros enfatizaram o papel da experiência de vitimização (direta e indireta) como fator importante no desenvolvimento do medo do crime (ver Lane, Rader, Henson, Fischer, \& May, 2014).

O medo do crime entendido como um indicador das preocupações com a segurança, a violência e/ou a criminalidade, retratando o amálgama de medos, sentimentos, julgamentos cognitivos e aspectos comportamentais relacionais a crime, tem amplas consequências em relação aos efeitos físicos, psicológicos, comportamentais e sociais (ver Lane et al., 2014). Esse medo pode repercutir em comportamentos prejudiciais para a saúde física das pessoas e para o bem-estar mental e influencia o comportamento das pessoas, por exemplo, envolvendo-as em estratégias de prevenção ao crime, como travar as portas e não andar sozinho à noite. Embora isso possa aumentar temporariamente a sensação de segurança, também pode levar à retirada social e ao desengajamento de atividades na comunidade, que são importantes, relacionadas ao bem-estar subjetivo. Dado que o medo do crime é principalmente um fenômeno psicológico, suas consequências devem ser mais proeminentes no nível psicológico. Uma grande parte da pesquisa individual tem corroborado que o medo 
do crime é prejudicial ao bem-estar subjetivo das pessoas (e.g., Cohen, 2008; Hanslmaier, 2013; Michalos \& Zumbo, 2000; Moore, 2006).

O que se pode constatar é que existe uma variedade teórica abrangente para o constructo, com constantes tentativas de associá-lo a outros objetos sociais, mais talvez do que entender de maneira um pouco mais aprofundada e consensual os aspectos que envolvem o medo do crime. Não é de se estranhar que também os instrumentos de mensuração são os mais diversificados e de áreas distintas do conhecimento (psicologia, antropologia, sociologia, entre outras). Essa "insuficiência conceitual" e a exacerbação do subjetivismo no entendimento do objeto criam barreiras de difícil transposição em seu estudo, ao tempo em que criam oportunidades interessantes para o preenchimento de lacunas ainda existentes. Oportunidade, por exemplo, de solidificação conceitual de um constructo relevante não só no campo acadêmico mas para a vida das pessoas, visto que, independentemente do nível de entendimento que se tenha acerca do medo do crime, este afeta direta ou indiretamente as ações cotidianas das pessoas e das instituições.

Ao abordar instituições, é inevitável tratar dos órgãos policiais, visto que, em muitas jurisdições, reduzir o medo do crime tornou-se, em um momento ou outro, um indicadorchave de desempenho para policiais de alto escalão (a falta de redução do medo pode ter repercussões nas carreiras de policiamento) e, de fato, um objeto de policiamento mais generalizado. No estado de Nova Gales do Sul (Austrália), a título de exemplo, as atuais responsabilidades do comissário de polícia são "reduzir o crime e reduzir o medo do crime" (DETR, 1998, p. 12). Na frente desse profissional, este é certamente um jogo digno de objetivos. No entanto, há um par de grandes ressalvas. Primeiro, há o problema técnico simples como já discutido sobre os níveis de medição do medo. Se o medo do crime é elevado pelas tecnologias atuais de mensuração - ou seja, se as pesquisas superestimam o medo do crime - o que se está buscando de fato é reduzir algo inexistente. O segundo 
problema talvez seja o mais impactante na realidade das instituições que lidam com eventos criminais: a interferência política. De fato, o medo do crime tornou-se palanque eleitoral até em condomínios privados, o que dirá em cidades, estados, províncias e países (Jackson \& Gouseti, 2014, 2012; Lee, 2008).

Por um lado, esse de fato, não é um problema significativo, à medida que possibilita o incremento do número de pesquisas voltadas a este mecanismo. Em algo similar com a discussão que envolve fenômenos divergentes, é salutar que várias correntes pesquisem o medo do crime, assim como também se verifica necessário certo consenso acerca dos seus atributos e novos caminhos a percorrer para o desenvolvimento do constructo, no intuito de acelerar sua compreensão e clarificar o contexto que envolve sua utilização, além da própria utilização de outras variáveis, particularmente atitudinais e ligadas a fenômenos ou objetos que, de alguma forma, façam remissão ao crime (Hale, 1996; Skogan, 1993), como no caso da atitude frente à arma de fogo.

\subsection{Pergunta de Pesquisa}

O medo do crime é, portanto, um fenômeno multidimensional, constituído pelas muitas possibilidades de reação diante de situações definidas como perigosas, bem como da própria representação do que seria uma ameaça. Trata-se de um objeto fluido, constituído a partir de uma multiplicidade de acontecimentos, atores e contextos, sendo realmente difícil de ser delimitado empiricamente, ao tempo em que tais aplicações empíricas possibilitam novos horizontes para o desenvolvimento teórico e empírico deste constructo ainda incipiente nas pesquisas nacionais, apesar de seu impacto social relevante (Carvalho, 2014; Porto, 2014).

A atitude frente à arma de fogo pode constituir-se em um facilitador na construção desse melhor entendimento do medo do crime, de maneira talvez ainda mais relevante do que 
em outros países que já desenvolveram pesquisas utilizando o constructo, em vista da diferença entre a legislação brasileira restritiva e a legislação mais flexível de outros países, quanto à posse e o porte desse objeto, tornando a ligação entre arma - particularmente a de fogo - e crime consolidada (Lima, 2006).

Os Valores Humanos Individuais podem ser definidos de forma simplificada, segundo Schwartz (1992, p. 22), “como conceitos do desejável que guiam a vida de atores sociais (e.g., líderes organizacionais, criadores de leis, indivíduos), selecionam ações, avaliam pessoas e eventos e explicam suas ações e avaliações". Apesar de Valores Humanos possuírem várias definições e escalas de autores diversos, sua centralidade reconhecida reforça o desenvolvimento de outras variáveis e constructos, servindo de antecedente para atitudes e comportamentos, como se pretende no estudo atual, perguntando-se portanto:

Qual a influência dos valores humanos individuais e da atitude frente à arma de fogo sobre o medo do crime na população de uma Região Administrativa do Distrito Federal?

\subsection{Objetivo do Estudo}

\subsubsection{Objetivo geral}

Compreender e descrever como os Valores Individuais e a atitude frente à arma de fogo influenciam o medo do crime em uma Região Administrativa do Distrito Federal (DF).

\subsubsection{Objetivos específicos}

- Mensurar os Valores Humanos Individuais, conforme proposto por Schwartz et al. (2012) e Torres et al. (2016), em amostras diferentes da população de uma Região Administrativa do DF. 
- Medir a Atitude Frente à Arma de Fogo, conforme proposto por Nascimento, Pimentel e Adaid-Castro (2016), em amostras da população de uma Região Administrativa do DF.

- Identificar e comparar o Medo do Crime entre as citadas amostras.

- Verificar possíveis associações entre Valores, Atitudes Frente à Arma de Fogo e Medo do Crime nas amostras estabelecidas, no contexto de segurança pública existente no momento.

Para responder à pergunta de pesquisa, alcançando os objetivos geral e específicos propostos, esta dissertação foi dividida em cinco capítulos. Após a introdução, já apresentada, segue o Referencial Teórico, onde serão apresentados aspectos conceituais, históricos e o desenvolvimento empírico das variáveis integrantes deste estudo, possibilitando o entendimento mais aprofundado do tema e a base para a construção do modelo da pesquisa. No relato do medo do crime é apresentado o delineamento do constructo e a discussão teórica ampla acerca do entendimento deste a partir de panoramas de ciências sociais com focos distintos.

Em seguida será apresentado o Método, voltado às escolhas metodológicas da investigação, justificando-se a população escolhida, os procedimentos de coletas de dados, apontando também os procedimentos para a adaptação, o desenvolvimento e a validação de instrumentos de medida utilizados na pesquisa. No capítulo de Resultados, são apresentadas as amostras utilizadas e as análises preliminares de adequação dos dados para a realização das análises multivariadas, com a posterior apresentação de evidências de validade da escala de medida do medo do crime, e os testes dos efeitos diretos e indiretos entre as variáveis pesquisadas. 
No quinto capítulo os resultados da pesquisa são discutidos e interpretados, com foco na discussão dos resultados do modelo de medida, das relações existentes no modelo estrutural e das possíveis influências advindas da variáveis sociodemográficas. Por fim, nas considerações finais desta dissertação, são retomados os objetivos geral e os específicos e a questão da pesquisa, apresentando, igualmente, as limitações da pesquisa e uma agenda para futuras investigações. 


\section{Capítulo 2}

\section{Referencial Teórico}

\subsection{Medo do Crime: Análise do Constructo}

\subsubsection{Breve introdução ao tema}

Nas últimas cinco décadas, o medo do crime tornou-se preocupação de crescente relevância para cientistas sociais de áreas distintas (particularmente os da área da Criminologia), como também para gestores públicos, políticos, instituições policiais, destacando ainda a mídia e o público em geral nesse contexto (Hale, 1996; Ditton \& Farrall, 2000). Na verdade, o medo do crime foi apontado, por estudos diferentes, como responsável por um número cada vez maior de doenças ou mazelas sociais. Por exemplo, o medo do crime é apontado como uma das causas para:

(i) tornar alguns lugares públicos áreas de "não convivência" ou de ausência de frequência de pessoas (Garofalo, 1981; Maxfield, 1984; Maxfield, 1987; Williams, McShane, \& Akers, 2000; Wilson, 1975);

(ii) dirimir o senso de comunidade e vizinhança, além do surgimento da suspeita entre vizinhos (Box, Hale, \& Andrews, 1988; Conklin, 1975; Maxfield, 1984; Skogan, 1986; Taylor \& Hale, 1986), levando alguns moradores a mudarem-se dos bairros onde residiam (Dugan, 1999), gerando nos locais um fator de declínio da comunidade;

(iii) abastecer a indústria de segurança privada, possibilitando a adoção, por parte principalmente dos mais ricos, de medidas efetivas de autoproteção (O’Malley, 1992), somando-se à ascensão das vendas de armas de fogo, em particular nos Estados Unidos (Edmondson, 1994; Jones, MacLean, \& Young, 1986). Estudos sobre a economia do crime indicam que outros setores, como o imobiliário, também apresentam ganhos em virtude de áreas mais ou menos "seguras" (Chancer \& McLaughlin, 2007, p. 156); 
(iv) potencializar racismo e a xenofobia, transferindo tal "ameaça do crime" a grupos minoritários (Chiricos, Hogan, \& Gertz, 1997; Sibley, 1995; Skogan, 1995);

(v) criar ações de "endurecimento", resultando em mais e mais pesadas medidas de justiça penal punitiva (Cohen, 1996, p.12 ; Hogg \& Brown, 1998, p.37);

(vi) encaminhar os indivíduos a efeitos psicológicos negativos (Gordon \& Riger, 1989; Skogan, 1986);

(vii) induzir algumas pessoas à mudança de atividades e hábitos diários por causa do medo de vitimização (Hough \& Mayhew, 1985; Jones, MacLean, \& Young, 1986; Keane, 1995, Stanko, 1990);

(viii) aumentar, de fato, os níveis de criminalidade, como resultado direto ou indireto de muitos dos efeitos citados anteriormente (Maxfield, 1984; Skogan, 1986; Skogan, 1989);

(ix) evitar que muitas mulheres apresentem um papel mais ativo na vida pública (Gardner, 1990; Garofalo, 1981; Gordon \& Riger, 1989; Stanko, 1990; Walklate, 1995);

(x) restringir a liberdade dos idosos (Akers, LaGreca, Sellers, \& Cochrane, 1987; Golant, 1984; La Grange \& Ferraro, 1987); e

(xi) constranger o modo como as mulheres se vestem ou se expressam (Smith, 1986; Stanko, 1990).

Interessante constatar também que, de maneira similar aos estudos dos fenômenos da violência e da criminalidade, a problemática do medo do crime, particularmente dos agentes públicos e políticos, de todos os níveis e áreas (Reiner, Livingston, \& Allen, 2000), levou a uma proliferação de pesquisas e literatura, de pesquisadores oriundos de campos distintos do conhecimento, gerando comentários eivados de humor, como o presente no artigo de Ditton, Bannister, Gilchrist e Farrall (1999), em que os autores afirmam que o "medo do crime se tornou maior que a General Motors” (Ditton, Bannister, Gilchrist, \& Farrall, 1999, p. 92). 
Ainda que tenha havido uma inegável expansão do campo de pesquisa envolvendo o medo do crime, as posições ideológicas e teóricas que desenvolveram e desenvolvem o constructo são, em muitos momentos, conflitantes. Esse debate ganha corpo em alguns pontos relevantes, incluindo a busca por explicações mais exatas do que pode ser realmente o medo do crime (Ferraro, 1995; Ferraro \& La Grange, 1987; Maxfield, 1984; Taylor, 1988), como ele pode ser medido (Fattah \& Sacco, 1989; Hale, 1996; Weatherburn, Matka, \& Lind, 1996), quais as causas que conduzem ao medo do crime e como ele pode ser remediado.

\subsection{Definição do Constructo}

Existem algumas indagações ainda com relação ao medo do crime, as quais criam posicionamentos diferentes na doutrina. Perguntas relacionadas às explicações acerca da diferença entre o medo do crime e a realidade do crime, percepções sobre o controle e probabilidade de vivência de situações de vitimização, o quão importante é a experiência passada ou os conselhos dos amigos e família quando se trata do medo do crime. Estas são algumas das lacunas que ainda persistem na literatura da área, o que faz questionar a base teórica de grande parte da pesquisa relacionada ao medo do crime.

Tais proposições têm alcançado maior sucesso nos relatos dos respondentes (diferenças relacionadas à idade, gênero e outros aspectos) do que na produção mais detalhada de descrições de como se manifesta a preocupação no cotidiano das pessoas, ou na tentativa de entender o porquê de as pessoas se sentirem ansiosas (Farrall, Bannister, Ditton, \& Gilchrist, 1997; Farrall \& Gadd 2004; Girling, Loader, \& Sparks, 2000; Gray, Jackson, \& Farrall, 2008; Hale 1996; Jackson, Farrall, Gray, \& Kuha, 2008). Vanderveen (2006) reforça este entendimento ao afirmar que muitos estudos estão preocupados com o que poderia ser chamado de prevalência do medo do crime, pouco se sabendo ainda sobre a variedade na natureza, o significado, a importância e a experiência do constructo na vida das pessoas. 
A literatura dominada por pesquisa de opinião pode ser adequadamente descrita, nas palavras de C. Wright Mills, como o empirismo abstrato (Mills, 1964), situação em que a sofisticação dos instrumentos aplicados em larga escala e dos procedimentos estatísticos não são acompanhados por uma teoria empobrecida. Hale (1996), ao realizar uma revisão profunda sobre o tema, reforça que de maneira geral, a literatura sobre o medo do crime produz uma sensação de que o campo está preso dentro de uma estrutura metodológica e teórica excessivamente restritiva, sendo necessária uma estratégia que "desembale" o conceito de medo do crime, possibilitando assim a abertura de área, rica para o debate (p. 83).

Tratando da conceituação propriamente dita, Garofalo (1981) define medo do crime como uma reação emocional caracterizada por um sentimento de perigo de ser vítima de dano físico (abarcando crimes contra a integridade física ou contra a propriedade), devendo tal reação ser provocada por sugestões percebidas no ambiente que se relacionam com algum aspecto do crime para a pessoa. Skogan (1983), por seu turno, trata o medo do crime como uma preocupação abrangente relacionada ao crime, baseada em experiências diretas (experimentadas pelo próprio indivíduo) ou indiretas (experimentadas por outrem), incluindo desde uma ideia geral sobre índices de criminalidade (taxas criminais subindo ou descendo), passando por julgamentos gerais sobre a natureza do crime (quão violento é) e dos criminosos (causas que os levam a praticar ilícitos), incluindo até a agenda pública sobre o crime (e quanto dinheiro a sociedade deve gastar para lidar com este fenômeno).

Para Jackson e Gouseti (2014), as reações emocionais e as percepções de risco estão no cerne do medo do crime, e uma maneira de abordar a ligação entre elas é focalizar a “preocupação" e não o "medo" (p. 1597). Os autores explicam que o medo capta inadequadamente as emoções da maioria das pessoas sobre a ameaça de se tornar vítima de um crime (e. g. Gray, Jackson, \& Farrall, 2011; Warr, 2000), visto que normalmente se 
constitui de resposta física forte a uma ameaça imediata e próxima, enquanto a preocupação, em outro viés, capta a avaliação das pessoas da ameaça imediata e distal.

A preocupação, para Jackson e Gouseti (2014) é tanto uma avaliação de uma situação imediata (pode-se preocupar-se com a ameaça de vitimização indicada por sinais próximos no ambiente) e a ruminação sobre resultados futuros (uma preocupação com ansiedade sobre eventos distais e futuros ainda a acontecer). Por outro lado, as pessoas continuam a se preocupar, a menos que possam aceitar a possibilidade do incerto futuro de uma ameaça, e fazem todos os esforços que podem para evitar ou lidar com ele. Além disso, os autores entendem a relevância do aspecto cognitivo do comportamento, corroborando o entendimento de Loewenstein, Weber, Hsee e Welch (2001), particularmente, enquanto responsável pela análise do risco do indivíduo tornar-se vítima de crime, seja por fatores ambientais, seja pela experimentação direta do fenômeno, ou por outras razões. Prosseguem os autores Loewensteins et al. (2001) no entendimento de que a interação entre o aspecto afetivo e o cognitivo tornam imprescindível também o aparecimento do aspecto comportamental, que diz respeito à predisposição de adoção de determinado comportamento, a partir das informações disponíveis acerca dos dois outros aspectos.

Gabriel e Greve (2003) definem o termo medo do crime como o medo do indivíduo de se tornar pessoalmente uma vítima de crime (em contraste com a preocupação geral com o crime apresentada por Skogan, 1993). Ao examinar o constructo de maneira mais específica, os autores asseveram que o medo do crime pode ser concebido como um conceito multifacetado. $\mathrm{O}$ aspecto fenomenologicamente saliente - a experiência (consciente) de sentir-se temeroso - é um conglomerado dessas facetas, refletindo principalmente a faceta afetiva. No entanto, os autores reforçam que o componente afetivo do medo deve ser sempre acompanhado por uma faceta cognitiva, ou seja, a percepção cognitiva da situação como ameaçadora ou perigosa, independentemente de quão vaga seja essa percepção. O terceiro 
componente do medo é uma faceta expressiva: comportamento temeroso ou de medo (por exemplo, comportamento de evitação e autoproteção).

Outros autores colaboram com a definição do fenômeno ao estabelecerem que o medo do crime pode ser entendido como um indicador das preocupações com a segurança (Gorman-Smith, Tolan, \& Henry, 2000), ou ainda pode ser compreendido como medos, sentimentos, julgamentos cognitivos ou emocionais e aspectos comportamentais relacionados ao crime (McCrea, Shyy, Western, \& Stimson, 2005). Importante salientar que a definição apresentada por alguns estudiosos do medo do crime vai ao encontro da teoria tripartite da atitude (e. g. Gabriel \& Greve, 2003; Jackson, \& Gouseti, 2014), exatamente como previram Pimentel, Günther e Black (2012), ao afirmarem que comumente o medo do crime é tratado como uma resposta emocional perante o crime. Entretanto o constructo tem sido mais pesquisado a partir de atitudes e crenças.

Tal entendimento torna-se relevante para a associação proposta nesta pesquisa, entre valores e medo do crime, como também para a compreensão dos atributos pertinentes ao constructo em destaque, até porque existem alguns autores que entendem o medo do crime de maneira dessemelhante, através de uma perspectiva com dois componentes (afetiva e comportamental, e. g., Ferraro, 1995; Warr, 2000), ou a partir de outras classificações. Embora a maioria dos objetos naturais e materiais possam ser contados e descritos, mesmo que a taxonomia destes seja elaborada de forma arbitrária (Foucault, 1970), e muitos objetivos científicos sociais do conhecimento claramente categorizados e delineados - como contar um delito por meio da descrição dos agentes de segurança ou da vítima, ainda que exista uma margem razoável de imprecisão - o medo do crime é tanto uma construção conceitualmente pobre (Ditton \& Farrall, 2000; Farrall \& Lee, 2009; Hale, 1996), como subjetivamente diverso. Neste panorama, é também preocupação significativa desta dissertação estabelecer um posicionamento conceitual acerca do medo do crime respaldado 
na discussão teórica realizada e no entendimento da necessidade de enriquecimento teórico do constructo para a consequente potencialização da mensuração e análise empírica deste. Antes, portanto, de explorar mais estes aspectos, faz-se imprescindível uma verificação histórica do constructo, no intuito de estabelecer melhor suas idiossincrasias e detalhes que auxiliem a compreensão abrangente do constructo.

\subsection{Histórico de Delineamento do Constructo}

Lee (2011) assevera que muito embora a sensação de medo seja, de uma forma ou de outra, própria da condição humana, o conceito de medo do crime, por sua vez, é uma construção sociocultural bem mais recente. Embora o constructo não estivesse completamente formado (ou até conceituado) até os anos 1960, algumas mudanças que começaram na metade do século XVIII lançam as bases desta formação, na opinião do autor. Novos modos de vida social, novas formas de organização social (Giddens, 1990), bem como o surgimento de tradições seculares baseados em torno de racionalidades científicas e da filosofia do Iluminismo estavam transformando as cidades da Europa Ocidental e os Estados Nacionais, ao mesmo tempo em que minavam convenções e noções feudais tradicionais de direito divino. Um ponto histórico importante para a emergência do mundo moderno foi a Revolução Francesa de 1789.

A expansão do comércio, da indústria e da agricultura levaria ao crescimento maciço das cidades europeias de forma proporcional à condução da mão de obra do campo para as grandes cidades, possibilitando uma lógica laboral que deveria satisfazer as exigências da Revolução Industrial até o século XIX (Burke, 2005). Este nascer da atividade industrial, com toda a sua efervescência e celeridade, trouxe alguns efeitos colaterais nocivos, conhecidos também como subprodutos (Hayward, 2004), tanto humanos como materiais, sufocando a infraestrutura das cidades e criando novos riscos e ansiedades. Sem qualquer tipo 
de surpresa, tais condições aumentaram - e aumentos percebidos - os comportamentos criminosos e imorais (Burke, 2005). Relevante salientar que tais mudanças, na visão de historiadores como Clive Emsley (1987), trouxeram diversas repercussões para as vidas dos indivíduos, como o medo das mudanças sociais que aconteciam em uma velocidade cada vez maior, e não à toa, entre 1750 e 1900, muitos dos elementos que mais tarde iriam "formatar" o medo do crime, ou torná-lo um conceito digno de preocupação acadêmica, já apareciam (p. 48).

É possível então supor que havia medo do crime no final do século XVIII? Na visão de Lee (2011) não é totalmente possível responder a uma indagação dessa natureza, visto que a visão moderna de medo do crime não se encaixaria em contextos próprios do período. Entretanto, podem ser identificados claramente os contornos de algo que no momento atual da história é inegavelmente conhecido como medo do crime. Emsley (1987) argumenta que as preocupações sobre o nível de desordem podem ser detectados entre as classes proprietárias da Inglaterra após Gordon Riots, em 1780. Um trecho interessante é exposto no obra de Emsley, quando em 1785, na obra Reflexões na Execução da Justiça, um magistrado conservador, de nome Martin Madan, sugeriu o seguinte:

Nenhuma nação civilizada (...) tem que lamentar, como nós temos, a comissão diária dos crimes mais perigosos e atrozes, de tal monta que não podemos viajar pelas estradas, dormir em nossas casas, ou cuidar de nossos animais em nossos campos, sem o perigo mais iminente de ladrões e assaltantes (Emsley, 1987, p. 61).

No século XIX é possível verificar situações semelhantes na Inglaterra e na França, muito embora em níveis diferentes de aceleração industrial, tanto que Chevalier (1973) descreve que a Paris de 1840 era uma cidade "doente", na qual "classes perigosas" ameaçavam uma burguesia cada vez mais assustada (p. 95). Tal contexto propiciou 
preocupações relacionadas à governança do crime, com regulação das vidas dos indivíduos integrantes destas "classes perigosas". Estatísticos sociais surgem, como o belga Quetelet (1984, publicado originalmente em 1827), e com eles novas técnicas estatísticas focadas mais especificamente tanto na prevalência geral como na distribuição espacial do crime, ou seja, com que frequência e onde ocorrem os crimes.

Nas décadas finais do século XIX, tanto a Grã-Bretanha como outros países europeus testemunharam a introdução de uma série de atos que visavam a maiores liberdades e direitos, estabelecendo melhor as suas práticas. Exemplo inconteste disso foram as restrições impostas ao trabalho infantil, à construção de prisões regulamentadas e a casas para medidas educativas compulsórias. Transformações semelhantes também estavam em curso nos Estados Unidos, onde novas categorias de pessoas consideradas perigosas e delinquentes estavam sendo distinguidos (Rose, 1999). Pike (1968), ao tratar da evolução do crime na Inglaterra, chega a afirmar que a sensação de segurança é difusa em quase toda a parte, estabelecendo um contraste gritante entre o momento atual (final do século XIX) e a sensação de insegurança que prevalecia no início do citado século.

O início do século XX marcou, por sua vez, o interesse sociológico e criminológico entre a mídia e o aumento da criminalidade. A tese, entretanto, não era de que a mídia aumentasse a ansiedade ou o medo do crime, mas teorias retratavam o fato de que as ofensas delituosas retratadas nos jornais apresentavam um alto nível de imitação, atualmente chamado de "copy-cat" (Lombroso, 2004/1897). Essa tese foi retomada por vários autores, como Fenton (1911), que sugeriu que a publicação de histórias de crime incitariam novos crimes, baseando-se na análise de seis jornais de circulação em um período de nove dias. Holmes (1929), na mesma esteira e lembrando os escritores que abordavam o tema da hipnose, posicionou-se no sentido de que o hipnotizador não pode fazer com que o indivíduo aja em contradição aos seus padrões morais, ainda que, indubitavelmente, na narrativa do 
autor, consiga desenvolver tendências preexistentes no sujeito. Holmes acrescenta ainda que muitos indivíduos podem ser levados a matar por sugestão, usando como exemplo maior deste fator a propaganda maciça de guerra com a utilização da mídia, para convencer as pessoas da importância de servir ao seu país.

Voltando um pouco o olhar para o Brasil, no Rio de Janeiro do século XIX, as elites brancas lidavam, de maneira cotidiana, com o medo da insurreição negra e com os desdobramentos do fim da escravidão no seu cotidiano. Batista (2003) elucida tal contexto ao trazer à luz o posicionamento de Chalhoub (1988), que chegou a afirmar que em uma gravura em que uma negra abana uma branca, o sentimento predominante dos proprietários brasileiros, já em meados do século XX, seria "similar à indignação diante da iminência do fim da brisa" (p. 92). Neder (1997) ressalta que conviviam questões étnicas e sociais na cidade do Rio de Janeiro, na virada dos séculos XIX e XX, aparecendo este convívio no discurso jurídico e policial do período. Assim como aconteceu na Europa, lideranças intelectuais e pensadores jurídico-policiais tratavam, frequentemente, das "classes perigosas", com reflexões dirigidas à periculosidade e tendências à criminalidade dos brasileiros de origem africana. Como exemplo, utiliza-se a obra A Polícia Carioca e a Criminalidade Contemporânea, de Elysio de Carvalho (1910), que propõe no currículo para a Escola de Polícia um curso intitulado "História Natural dos Malfeitores", em que aparece a influência do determinismo biológico, dirigido particularmente aos afrodescendentes.

\subsection{O "Surgimento" do Constructo}

Nos EUA, em meados da década de 1960, várias organizações foram contratadas para realizar pesquisas e produzir relatórios para a Comissão Presidencial sobre Aplicação da Lei e Administração da Justiça. Tais organizações, como relata Lee (2011), começaram a entrevistar cidadãos individualmente sobre suas experiências de vitimização do crime com o 
objetivo de obter dados mais precisos sobre os níveis de crime não declarados, também conhecidos como cifras ocultas ou cifras negras (Aniyar de Castro, 1983), além de focar no estudo das percepções da população em geral acerca do crime.

O Serviço de Pesquisa em Ciências Sociais - BoSSR, em inglês - (Biderman, Johnson, McIntyre, \& Weir, 1967), localizado em Washington, o Centro Nacional de Opinião - NORC, em inglês - (Ennis, 1967) e a Universidade de Michigan - UoM, em inglês (Reiss, 1967), produziram relatórios sobre o fenômeno, em 1967, de trabalhos iniciados em 1965. Tais relatórios, respectivamente denominados de Relatório de Estudo Piloto no Distrito de Colúmbia sobre Vitimização e Atitudes diante da Aplicação da Lei - Levantamento de Campo I, Vitimização Criminal nos Estados Unidos: Um Relatório de Pesquisa NacionalLevantamento de Campo II, e Estudos sobre Crime e Aplicação da Lei em Grandes Áreas Metropolitanas - Levantamento de Campo III e seus relatórios subsequentes, levaram ao surgimento dos Levantamentos Nacionais sobre o Crime, posteriormente realizados regularmente com o censo estadunidense do Serviço de Estatísticas da Justiça (Gordon \& Riger, 1989; Hoyle \& Zedner, 2002).

Lee (2011) destaca que, muito embora nenhum desses instrumentos e outros que vieram na sequência voltavam-se ao medo do crime, todos apresentam uma discussão interessante sobre o tema e sobre as percepções dos sujeitos acerca do crime, propiciando aos respondentes discutirem os receios da comunidade. Outra observação relevante sobre os relatórios é que enquanto Reiss (1967) é bastante cauteloso em sua discussão sobre o medo do crime - raramente usando o próprio termo em seu relatório - e Ennis (1967) preocupou-se com a potencial politização do medo do crime, Biderman, Johnson, McIntyre e Weir (1967, p. 119) defenderam que “(...) os entrevistados acreditam que o problema do crime em Washington é sério, que está piorando e que é uma preocupação imediata para si mesmos. 
(...) $\mathrm{O}$ medo de um mal que pode vir a acontecer a eles, e a suas famílias, tem impacto considerável na vida cotidiana das pessoas que entrevistamos."

Na visão de Lee (2011) se houver um ponto zero, um epicentro relacionado ao medo do crime, essas pesquisas o constituíram, pois embora elas não tenham inventado o discurso do medo do crime, ajudaram e muito a darem forma ao constructo como objeto de pesquisa. Este entendimento é reforçado pela observação dos itens integrantes da pesquisa, visto que no Relatório NORC (Ennis, 1967), por exemplo, estão contidas pela primeira vez, perguntas diretas de pesquisas sobre medo do crime, sobre a preocupação com o estilo do ambiente em que vivem ou que frequentam os respondentes, entre outras questões. A introdução dessa seção no relatório demonstra esta preocupação reforçando que "as pessoas foram indagadas sobre como se sentiam ao sair sozinhos à noite em sua vizinhança, sobre como estavam preocupados em ter suas casas invadidas, e assuntos relacionados” (Ennis, 1967, p. 72).

Em seguida, Harris (1969) lançou a primeira obra com o medo do crime estampado no título, que demonstra simbolicamente a genealogia do constructo, além de externar os receios da população no contexto das manobras políticas. Assim, segundo o autor, a verificação da existência e da relevância para a população do medo do crime, e como este constructo era independente de outras variáveis como o próprio crime, a percepção de risco e outras similares, tornou-se discurso das autoridades americanas, incluindo o Presidente - Lyndon B. Johnson - e o Congresso, o que possibilitou, inclusive, a aprovação de leis que davam poderes menos restritos aos órgãos policiais em prender suspeitos, aproveitando as redes de comunicações dos bairros, por exemplo.

No início da década de 1970, as pesquisas de vitimização americanas já eram aplicadas em larga escala e marcavam um novo regime sobre os níveis de vitimização e do medo do crime em si. E no embalo do movimento surgido nos EUA, foram criadas pesquisas em outras democracias ocidentais, como no caso australiano, que criou o Serviço NSW de 
Estatísticas e Pesquisas Criminais em 1969 e o Instituto Australiano de Criminologia (AIC, em inglês), uma autoridade estatutária do Commonwealth, foi estabelecido em 1973 (Lee, 2011). Já no Reino Unido, essa tarefa foi direcionada para o UK Home Office, embora as pesquisas criminais estivessem, normalmente, ligados a outros institutos de investigação, como o Instituto de Criminologia da Universidade de Cambridge (Radzinowicz, 1999).

Na verdade, como apresentam Brake e Hale (1992), as sementes para as grandes pesquisas nacionais sobre dados criminais no Reino Unido surgiram na obra Questões Chave em Criminologia (Hood \& Sparks, 1970), em que os autores discutiram, entre outros aspectos, as novas formas de levantamento de vitimização realizadas nos EUA, que na visão deles oferecia um olhar novo sobre a "figura escura" do crime (p. 14). Ato contínuo, Sparks, Genn, e Dodd (1977) realizaram uma pesquisa de vitimização em Londres, com influências das pesquisas americanas, que serviu de estudo piloto para a aplicação da Pesquisa Britânica sobre o Crime (BCS, em inglês), que teve sua primeira aplicação realizada em 1982 (Brake \& Hale, 1992), preocupando-se em buscar o medo do crime, vindo o constructo a tornar-se um dos pilares desta pesquisa.

Talvez o BCS seja um dos instrumentos mais interessantes para se tratar a respeito do medo do crime, pois os criminologistas representantes do governo e envolvidos na aplicação do BCS original possuíam convicções semelhantes às de autores críticos, como Cohen - que escreveu a obra Demônios do Povo e Pânicos Morais: a Criação de Mudanças e Oscilações, em 1972 - ou seja, tentavam mostrar como os receios eram exagerados, amplificados, pairando certa noção de irracionalidade com relação a tais sensações dos indivíduos, ainda que implícitas (Maxfield, 1984). Ao invés disso, aconteceu exatamente o fenômeno contrário: os dados obtidos no BCS começaram a ser usados para sugerir maneiras pelas quais os hábitos das pessoas poderiam contribuir para sua própria vitimização, oferecendo uma 
política pública de nível micro, podendo ser utilizada na redução de riscos de alguns grupos sociais.

Já que os pesquisadores verificaram que constructo medo do crime existia de fato, em concomitância ao seu "surgimento", foram realizadas várias pesquisas e novos posicionamentos teóricos e empíricos foram sendo verificados. Estudos empíricos descobriram, de maneira consistente e repetida, que as mulheres possuem mais medo do crime em comparação aos homens, ainda que estejam menos propensas a se tornarem vítimas da maioria dos crimes, particularmente os considerados mais graves - à exceção da agressão ou violência sexual e violência doméstica (Goodey, 1994; Lee, 2011;Walklate, 1995). Uma exceção interessante a esta tendência é o trabalho de Sutton e Farrall (2005), no qual os autores sugerem a inclusão de uma "escala de mentira" (p. 219), voltada a demonstrar que os homens são menos sinceros a respeito dos seus níveis de medo do crime, em comparação às mulheres, em razão da desejabilidade social.

Ademais, como os governos se posicionaram acerca do medo do crime também é um tópico que ganhou força, particularmente nas pesquisas americanas e britânicas, com posicionamentos dos pesquisadores no sentido de que as ações e estratégias governamentais, no lugar de aliviar a ansiedade sobre o crime, acabaram por alimentar o medo nos cidadãos (Egger, 1997; Young, 1996). Tal posicionamento foi corroborado pelos achados de Simmons e Dodd (2003), ao sugerirem que os níveis de medo de crime se mantiveram constantes (e altos), apesar de quedas relativamente drásticas em algumas categorias de infrações penais em diversos países ocidentais. Lee (2011) acredita que o sucesso da propagação do medo do crime por parte dos governantes, como estratégia política inclusive, possibilitou a omissão de falhas de agências governamentais voltadas ao controle da ordem pública, como também propiciou o consumo de serviços de segurança do setor privado para autodefesa dos indivíduos e de suas famílias (Dear, 2000). 
A representação da mídia acerca do medo do crime também foi objeto de estudo em diversas pesquisas, as quais por vezes demonstravam como crimes violentos podem ser utilizados por diversas semanas e gerarem novas pautas acerca de assuntos coligados, como a necessidade de endurecimento das penas aos condenados, a erosão do tecido moral do sociedade, a necessidade de maior número de policiais nas ruas, entre outros (Madriz, 1997). Hogg e Brown (1998), acerca do tema, exploraram leituras parciais das taxas e estatísticas criminais por meio da imprensa, no sentido de que, ainda que ocorresse redução de índices, as razões apontadas seriam que as pessoas estariam com medo de denunciar o crime, ou os serviços públicos de atendimento da população são falhos, ou ainda outros fatores.

De tudo exposto, verifica-se que o "surgimento" e o fortalecimento do medo do crime levou o constructo a ser objeto de estudos, posicionamentos governamentais, discussões teóricas e empíricas, o que aumentou o interesse por seu estudo, tornando-o independente do estudo do crime em si. Em acréscimo, esse movimento revelou alguns avanços que deveriam ocorrer na área, em vista da falta de consenso acerca de determinados aspectos relevantes do constructo, como também pela concentração notória destes em países anglo-saxões, tornando indispensável a realização de pesquisas transculturais para um entendimento mais aprofundado do tema.

\subsection{Segmentação Teórica}

Farrall, Gray, e Jackson (2007), em uma revisão teórica acerca do assunto, estruturam seu estudo em cinco segmentos teóricos distintos: (i) vitimização direta, (ii) vitimização indireta e psicologia do risco, (iii) desordem, coesão e eficácia coletiva - percepção ambiental, (iv) mudanças estruturais e influências de nível macro no medo, e (v) conexão de ansiedades relacionadas ao crime com outros tipos de ansiedade. Ambas as divisões apresentam proximidades e similaridade em praticamente todos os parâmetros de divisão e, 
como diferença única, Farrall et al. (2007) segmentam o campo de pesquisas propostos por Hale (1996), com ênfase no papel dos fatores psicológicos na produção de ansiedade, em dois, reforçando as mudanças estruturais e influência de nível macro e a conexão de ansiedades relacionadas ao crime com outros tipos de ansiedade. Utilizando esta segmentação teórica, propõe-se a verificação mais detalhada dos segmentos estabelecidos.

\subsubsection{Vitimização direta}

Aprofundando um pouco as dimensões teóricas apresentadas pelos autores, reforça-se que uma das primeiras abordagens para explicar o medo do crime postulou que o risco do crime e da experiência pessoal direta de vitimização foram de significativa relevância para entender por que algumas pessoas afirmam estar preocupados com o crime, enquanto outros não (Lewis \& Salem, 1980). Neste sentido, o medo do crime é definido como parte do produto de vitimização, estabelecido em uma relação direta com experiências reais de vitimização (vitimização direta) ou com a probabilidade maior de vitimização futura (e. g. Balkin, 1979; Liska, Sanchirico, \& Reed, 1988; Skogan, 1987). Significa dizer que os autores vislumbram o medo do crime dentro do universo de possibilidades de vitimização (vitimização direta, indireta, futura, influência de aspectos ambientes, sociais, econômicos, entre diversos outros aspectos), ou seja, as pessoas apenas ativam esse medo a partir do momento em que aspectos ligados à vitimização são ativados no indivíduo.

Este modelo é de longe, na visão dos autores, o modelo mais simplificado de medo: níveis de medo do crime dentro de uma comunidade são causadas pelo nível de atividade criminosa dentro dessa comunidade. Essa posição teórica ligada à vitimização, no entanto, só foi parcialmente apoiada pelos resultados empíricos até então existentes (Hale, 1996), havendo alguma evidência de que a experiência de vitimização direta está relacionada com certos tipos de crime (e.g. Covington \& Taylor, 1991; Rountree, 1998; Garofalo, 1979; Liska et al., 1988; Skogan, 1981, 1987; Stafford \& Galle, 1984;). 
Entretanto, essa experiência de vitimização parece apenas uma pequena parcela de qualquer explicação mais completa acerca do medo do crime, pois foram encontradas fracas correlações tanto entre o medo e as taxas de criminalidade, quanto entre aquele e as taxas de experiências individuais de vitimização, dando origem inclusive ao que vários autores denominaram paradoxo do risco-medo: mais pessoas se preocupam com o crime do que a quantidade de pessoas realmente suscetíveis de serem vítimas, além das pessoas "erradas" estarem preocupadas (Conklin, 1975; Dubow, McCabe, \& Kaplan, 1979; Hale, 1996). Neste sentido, as pessoas que mais se preocupam com o crime estão, em muitos resultados empíricos, menos sujeitas a se tornarem vítimas de crimes, tornando inócua, ou pelo menos inadequada, a explicação de que o "crime provoca medo".

Este paradoxo do risco-medo também se apresenta em grupos sociais, pelo fato de que alguns dos grupos em maior risco de vitimização se posicionaram relativamente sem medo (por exemplo, jovens do sexo masculino) e alguns dos grupos sociais menos prováveis de serem vitimados são relativamente temerosos (por exemplo, as mulheres mais velhas, embora a preocupação com o crime no Reino Unido diminua à medida que aumenta a idade, segundo Jackson et al. (2008).

Wang (2013) cita os estudos de Xie (2005), que encontrou uma relação inversa ao apresentado nos estudos estadunidenses e europeus (e.g. Acierno, Rheingold, Resnick, \& Kilpatrick, 2004; Burke, 2005), demonstrando que em Taiwan, quanto maior a idade, menor o medo do crime. Mesmo com a inclusão da variável gênero, a relação inversa permanece verdadeira, em geral, para as mulheres (novamente contrariando os achados estadunidenses e europeus, que elencam mulheres e idosos como grupos com maiores percepções de medo), não acontecendo o mesmo com os homens. Os adultos (35-54 anos) e jovens adultos (19-34 anos) taiwaneses apresentam mais medo de se tornarem vítimas de roubo de carros/scooters, quando comparados a grupos de jovens (10-18 anos) e idosos (55-84 anos), enquanto os 
últimos apresentam maior temor de utilizar táxis sozinhos à noite. Em que pese haver uma explicação lógica para este contexto - os adultos possuem veículos particulares e os jovens e idosos precisam mais de transportes públicos e táxis - Xie (2005) salienta que quase todas as faixas etárias de ambos os gêneros (à exceção de mulheres e homens jovens e de jovens adultos homens) possuem muito medo de serem vítimas de sequestro.

Alguns estudiosos das ciências sociais têm respondido que a natureza da vitimização experimentada por esses grupos com maiores níveis de medo (mulheres e idosos), foi refratária aos procedimentos de pesquisa quantitativa (Stanko, 1985 e 1988). Outros têm argumentado que a vitimização vai realmente reduzir o medo do crime desmistificando o desconhecido, e outro grupo tem sugerido que é a quantidade de vitimização que é importante (Agnew, 1985). Por outro lado, Smith e Hill (1991) descobriram que, depois de ponderação da gravidade da vitimização, a vitimização relacionada a crimes contra a propriedade (furto e roubo contra o indivíduo ou em desfavor de sua residência) foi significativamente relacionada ao níveis de medo do crime, o que não ocorreu com a vitimização dos crimes contra a pessoa (lesão corporal, sequestro, homicídio).

Uma série de questões metodológicas, no entanto, têm dificultado a busca pelo impacto da vitimização no medo. Em primeiro lugar, Sutton e Farrall (2005), como já relatado, descobriram que os homens parecem suprimir os níveis de medo e que, quando este era admitido, homens (em vez de mulheres) apresentaram maiores níveis de medo. Isto sugere que, como os homens são mais propensos a ser vítimas do que as mulheres, pode muito bem haver uma ligação entre vitimização e medo, mas esta tem sido escondida pela desejabilidade social do sexo masculino em situações de entrevista. Em segundo lugar, os entrevistados são perguntados, normalmente, apenas sobre as experiências de vitimização que tenham ocorrido durante os últimos 12 meses, sendo que uma experiência pode ter um impacto por um período maior (Jackson, 2008). 
Em terceiro lugar, como Bowling (1993) argumenta, pesquisas de vitimização reduzem ou focam o olhar da vítima para um único evento, no lugar de tentar estabelecer e entender um processo mais complexo e fluido que envolve o tema, demonstrando a incipiência dos métodos de pesquisa empregados na temática. Em quarto lugar, a investigação nas últimas décadas do século XX têm utilizado medidas inconsistentes do medo do crime, o que poderia explicar a inconsistência verificada na relação entre o crime e o medo (LaGrange, Ferraro, \& Supancic, 1992).

Finalmente, definições legais de crime e, consequentemente, de vitimização, tendem a excluir experiências desagradáveis que possam ser relevantes para o mal-estar público, como a intimidação, os telefonemas obscenos e o assédio sexual. Phillips (2000) e Vanderveen (2006) discutem as complexidades do comportamento indesejado e do assédio diário contra as mulheres, as quais relatam que a atenção do sexo masculino pode ser sentida como agressiva e contraditória, em muitas oportunidades. Tal "continuum de violência" (Kelly, 1987, p. 47) tem atos relativamente menores de abuso, em uma extremidade ('piscando' e por formas menores de abuso sexual), e na outra, atos como estupro (e.g. Gardner, 1990; Hollander, 2002; Madriz, 1997; Pain, 1997; Stanko, 1985, 1987, 1990, 1997). Neste sentido, até mesmo os atos relativamente menores fazem com que as mulheres lembrem da possibilidade de serem vítimas de formas mais graves de violência, provocando assim o medo.

Como se posicionam Farrall et al. (2007), qualquer que seja a explicação para os resultados gerados por esta via de investigação teórica, a alegação de que o medo do crime é simplesmente (ou exclusivamente) o resultado de vitimização parece simplista e injustificada pelos dados disponíveis, que ora ratificam esta relação, mas na maior parte dos estudos publicados demonstra dados contraditórios e não conclusivos acerca desta relação (Liebnitzky, \& Montero, 2013). 


\subsubsection{Vitimização imaginada e Psicologia do Risco}

O segundo modelo teórico apresentado por Farrall et al. (2007) afirma que as pessoas se preocupam com o crime quando elas podem imaginar-se como vítima efetivas deste. Esta sensação pode ser experimentada ao saber sobre o acontecimento de eventos criminosos ou mesmo conhecendo outras pessoas que já foram vítimas - estes são pensados para aumentar a percepção dos riscos de vitimização (Covington \& Taylor, 1991; Ferraro, 1995; Hough e Mayhew, 1995; LaGrange et al., 1992; Skogan \& Maxfield, 1981; Tyler, 1980, 1984).

Taylor e Hale (1986, p. 152) descrevem esse contexto como um "um crime 'multiplicador': processo que opera no ambiente próximo ao do indivíduo e que 'espalha' os impactos de eventos criminais". Skogan (1986, p. 203) refere-se aos termos vitimização direta e indireta como "conhecimento primário e secundário das taxas de crime da vizinhança ou do bairro". Hale (1996) conclui que as experiências indiretas de crime podem desempenhar um papel mais forte na ansiedades sobre a vitimização direta. Box, Hale, e Andrews (1988) encontraram evidências que sugerem que a vitimização indireta aumentou o medo, enquanto a vitimização direta não o fez, como relatou Arnold (1991). Ainda que a vitimização indireta pareça explicar, em parte, níveis globais maiores de medo, muitos indivíduos só tomam conhecimento de crimes de maneira indireta, por meio de canais que podem exagerar, utilizar eufemismos, ou mesmo deturpar a realidade dos fatos (Skogan, 1986; Liebnitzky \& Montero, 2013).

Ouvir sobre acontecimentos desagradáveis pode estimular percepções pessoais de risco que são, em essência, complexas e multifacetadas (Jackson, 2006). Esboçando um esquema para vulnerabilidade no medo do crime, Killias (1990) identifica três dimensões: a exposição ao risco, a antecipação de consequências graves e a perda de controle (falta de defesa eficaz, medidas de proteção e/ou possibilidades de fuga). Todos estes são necessários 
para produzir o medo e cada dimensão de ameaça também está associada a aspectos físicos, sociais e situacionais de vulnerabilidade. Killias \& Clerici (2000) afirmaram que se espera a incidência de consequências mais gravosas entre as mulheres, os idosos e as pessoas em condições debilitantes de saúde (fatores físicos), entre as vítimas sem redes de apoio social (fatores sociais) e em áreas desertas onde não há ajuda disponível (fatores situacionais).

Um desenvolvimento do modelo de sensibilidade de risco (ou psicologia do risco) ligado à probabilidade de que algo vai acontecer, ao controle que se tem do fato e de que consequências este fato trará - realizado por Jackson (2009) constatou que as probabilidades subjetivas previram fortemente a frequência de preocupação, mas também que capacidade de controle e consequência dos fatos estabeleceu dois papéis fundamentais: (a) eles (controle e consequência) moldaram o juízo de probabilidade, e (b) moderaram o impacto da probabilidade no medo (Jackson, 2011).

Em suma, olhando para os resultados desses estudos, uma dinâmica fundamental para o medo do crime surge, envolvendo tanto a sensibilidade ao impacto da vitimização (Ferraro, 1995; Warr, 1984, 1985) quanto o controle sobre sua ocorrência (Tulloch, 2003; Jackson 2004, 2009, 2011). Aqueles com menos recursos (reputa-se esta condição às pessoas do sexo feminino, idosos e aqueles em grupos socioeconômicos mais desfavorecidos) podem ser menos capazes de se proteger e de lidar com as consequências e, portanto, mais propensos a relatar ansiedade sobre vitimização.

Ainda sobre relatos de vitimização de outrem ou vitimização indireta, a mídia é, naturalmente, uma grande fonte de informações sobre o mundo, mas de acordo com Hale (1996) posições conflitantes surgem em estudos sobre o impacto dos meios de comunicação em geral, sobre o medo. Ouvir sobre o crime por meio da mídia pode repercutir em vitimização "imaginada" - especialmente em situações em que os indivíduos visualizam 
semelhanças com as vítimas relatas pela mídia, ou ainda, quando o evento ocorre em circunstâncias familiares (Winkel \& Vrij, 1990, p. 253).

Smith $(1985$, 1986) rememora que os relatórios da mídia dramatizam, trazem sensacionalismo e comunicam apenas os crimes mais graves - ainda que a incidência destes seja percentualmente bem menor em relação aos outros crimes, em muitos países -, pautando a definição da agenda da opinião pública e revelando um mundo arriscado e perigoso (Hanslmaier, 2013; Reuband, 2009). Outro achado interessante de Tyler $(1980,1984)$ e de Tyler e Cook (1984) sobre as diferenças entre os relatos da mídia de massa sobre o crime e os pertinentes aos amigos da família tiveram impactos diferentes sobre os níveis de risco sociais e pessoais percebidos. Segundo estes estudos, qualquer pessoa pode ser influenciada pelos meios de comunicação para sentir que o risco para a sociedade é maior do que se pensava, mas esse julgamento de risco elevado não irá afetar, ao menos não significativamente, o julgamento de risco pessoal.

O crime pode entrar em um emaranhado simbólico com questões de coesão social, porque o ato de crime comunica hostilidade dirigido à ordem social de uma comunidade e danos à sua estrutura moral (Jackson, Allum, \& Gaskell, 2006). A prevalência de crime pode, assim, demonstrar que a comunidade esteja sofrendo de deterioração dos padrões de comportamento, diminuindo o poder de controle social informal, aumentando a diversificação de normas e valores, além de diminuir os níveis de confiança, reciprocidade e respeito. Nota-se, em acréscimo, que a explicação sobre a vitimização "imaginada" é consistente com uma influente trajetória da política de controle de crime ao longo das últimas décadas, particularmente nos EUA e Reino Unido, fazendo com que o crime transpassasse de um problema restrito a determinadas "classes sociais" (leia-se pobres), para uma visão diária para uma gama significativa de sujeitos (Garland, 2001). 


\subsubsection{Percepção ambiental}

A ideia de que os sinais de desagregação dos bairros e a deterioração dos controles sociais influenciam a prevenção pública do risco criminal é consistente com diversos estudos (e.g. Ferraro, 1995; Garland, 2001; Lewis \& Maxfield, 1980; Lewis \& Salem, 1980, 1981). Uma revisão da literatura sobre o medo do crime revela que a localização geográfica tem recebido bastante atenção da pesquisa (Ferguson \& Mindel, 2007; Rountree, 1998).

Um consenso entre os estudiosos prevalece que o medo é em grande parte induzido por elementos discerníveis do ambiente externo, e a localização geográfica tem sido demonstrado ser um importante fator de mediação (Wyant, 2008; Zhao, Lawton, \& Longmire, 2010). Na verdade, os níveis de medo do crime variam substancialmente ao longo do tempo, do dia e espaço; locais como shoppings, o centro da cidade e a residência dos indivíduos diferem exatamente como diferem os níveis de medo do crime durante o dia e à noite (Doran \& Burgess, 2012).

Uma medida do medo do crime/segurança pessoal frequentemente empregada por pesquisadores implica a utilização de duas perguntas incluídas na Pesquisa Nacional de Vitimização do Crime (NCVS, em inglês): pergunta-se às pessoas o quão seguro elas se sentem quando estão fora de seus bairros e sozinhas à noite e quão seguras elas se sentem durante o dia (Luo, Ren, \& Zhao, 2016). Estudos utilizando esta medida particular tendem a destacar a importância da localização geográfica, em particular os bairros residenciais, na formação de avaliação cognitiva dos cidadãos da sua segurança pessoal (Gibson, Zhao, Lovrich, \& Gaffney, 2002; Hinkle \& Yang, 2014; Rountree, 1998).

Também consistente com Garland (2001) é a ideia de que os sinais de desagregação bairro e a deterioração dos controles sociais influenciam a percepção pública da criminalidade risco (ver também Lewis \& Maxfield, 1980; Lewis \& Salem, 1980, 1981; Ferraro, 1995) . "Desordem" é qualquer aspecto do ambiente social e físico que indica ao 
observador: (a) a falta de controle e preocupação, e (b) os valores e intenções de todos que compartilham o espaço (Covington \& Taylor, 1991; Ferraro, 1995; Innes, 2004; Jackson, 2004; Jackson \& Sunshine, 2007; LaGrange et al., 1992; Lewis \& Salem, 1986; Perkins \& Taylor, 1996; Skogan e Maxfield, 1981; Smith, 1986; Taylor, 1999; Taylor \& Hale, 1986; Skogan, 1990; Wilson \& Kelling, 1982).

De acordo com Ferraro (1995), as incivilidades são pequenas violações de normas comunitárias que sinalizam uma erosão das regras e valores convencionalmente aceitos. Analisando dados de uma pesquisa nacionalmente representativa de cidadãos norteestadunidenses, ele descobriu que as incivilidades forneciam informação ecológica que moldou as percepções das chances de vitimização dos cidadãos, incluindo a percepção de risco por eles vivenciada, repercutindo em expansão do medo do crime expressado pela população. Shaw e McKay (1942) foram os primeiros a apontar os efeitos degradantes causados por sinais de transtorno para as comunidades. Vários estudos descobriram que indicadores de incivilidade têm uma relação direta e positiva com o crime e o medo (Brief, Dietz, Cohen, Pugh, \& Vaslow, 2000; Perkins, Wandersman, Rich, \& Taylor, 1993; Raudenbush \& Sampson, 1999; Robinson, Lawton, Taylor, \& Perkins, 2003; Taylor \& Hale, 1986).

A pesquisa voltada às taxas de criminalidade da comunidade também refletem a influência da Teoria das Janelas Quebradas de Wilson e Kelling (1982). Em sua obra clássica, os autores postularam que as incivilidades físicas e sociais são positivamente correlacionadas e contribuem para o aumento da criminalidade e do medo. Os residentes que vivem em zonas desfavorecidas podem perceber seus arredores imediatos em termos negativos, causando um ciclo de agravamento do medo e da retirada da comunidade (Skogan, 1990). Em um outro polo do contexto, altos níveis de eficácia da comunidade, coesão social, e uma estrutura social próxima (com baixos níveis de anonimato e de desconfiança) podem 
inibir o medo do crime. Ross \& Jang (2000) descobriram que laços sociais informais amortecem o impacto da desordem no medo e na desconfiança. Esta observação é consistente com uma pesquisa posterior que encontrou um medo do crime inferior para os indivíduos que percebem menos incivilidades e um maior sentido de coesão e controle (Brown, Perkins, \& Brown, 2003).

A análise efetivada por Abdullah, Marzbali1, Bahauddin, e Tilaki (2015), com 235 residentes da cidade de Penang, Malásia, forneceu suporte empírico, tanto para a Teoria das Janelas Quebradas quanto para os resultados de estudos anteriores que não eram idiossincrática para os anos 1980 e os anos 1990, como articulado por Wilson e Kelling (1982) e Sampson, Raudenbush, e Earls (1997), entre outros. As conclusões do trabalho de Abdullah et al. (2015) foram consistentes com as de pesquisas relacionadas à Teoria das Janelas Quebradas, eficácia coletiva e percepção de incivilidades (Pitner, Yu, \& Brown, 2012), nas quais se demonstrou que a presença de incivilidade e o sentido de coesão podem afetar as preocupações dos residentes sobre a segurança no bairro ou da vizinhança. Tais achados são relevantes à medida que corroboram com as conclusões do estudo clássico inicial, demonstrando que estas não foram artificiais, mas iluminadas por um padrão empírico subjacente, que tem persistido ao longo do tempo (Gibson, Zhao, Lovrich, \& Gaffney, 2002).

Outro paradigma teórico bastante influente em termos de percepção ambiental é a Prevenção do Crime Através do Design Ambiental (CPTED, em inglês) (Lorenc et al., 2012). CPTED enfatiza três conceitos-chave como mediadores entre $\mathrm{o}$ ambiente físico $\mathrm{e}$ criminalidade e outros resultados negativos: (a) a propriedade ou territorialidade, (b) vigilância, e (c) controle de acesso (Cozens, Hillier, \& Prescott, 2001; Robinson, 1999). Os teóricos do CPTED recomendam práticas de design específicas para aumentar esses mediadores, por exemplo, demarcando e diferenciando, claramente, espaços públicos e privados e removendo sinais visíveis de negligência (lixo, pichações, entre outros), para 
promover a territorialidade (Taylor, 2002); melhorando a visibilidade para aumentar a vigilância; e limitando os pontos de entrada para controlar o acesso.

\subsubsection{Mudanças estruturais e influências (de nível macro) no medo}

Influências de nível macro sobre o medo incluem mudanças no nível de bairro/vizinhança e as alterações no nível da sociedade. Tratando das alterações do bairro/vizinhança nos EUA, Skogan (1986) afirma que o medo do crime nos bairros em declínio nem sempre refletem com precisão os níveis de criminalidade reais, sendo derivado de outros fatores como o conhecimento primário e secundário das taxas criminais do local, evidências observáveis de desordem física e social, além de preconceitos decorrentes de variações na composição étnica do bairro/vizinhança.

Greenberg (1986) esboça um modelo de viabilidade econômica do medo do crime, que se move para a confiança pública na trajetória de bem-estar econômico na sua vizinhança. Sua hipótese era que a preocupação com o futuro econômico do bairro poderia aumentar a sensação de vulnerabilidade dos indivíduos no que concerne a eventos que estão além de seu controle, uma das quais é o crime. Ela descobriu que a percepção de desordem e a confiança no bem-estar econômico mediam o impacto nos níveis de medo do crime do bairro/vizinhança.

Taylor e Jamieson (1998) apresentaram uma perspectiva um pouco diferente, mas em uma mesma linha, ao argumentarem que os altos índices de medo do crime vivenciados no Reino Unido, em meados dos anos 1990, eram sintomáticos da queda do Reino Unido de um nível de potência econômica líder no mundo a um importador líquido de produtos e serviços. A sensação de declínio econômico, no entendimento de Taylor e Jamieson (1998), levou a um sentimento de insegurança generalizada, especialmente no que se relaciona com o emprego. Estes medos de quedas (sociais) são causadas, na visão de ambos, pelas mudanças 
bruscas na economia naquela época, mas são condensados e mais facilmente expressados por meio do medo do crime e dos indivíduos que representam este "discurso moral" (p. 161) da criminalidade (arruaceiros, pessoas sem-teto, “jovens", minorias étnicas, "estrangeiros" - no sentimento de imigrantes - e assim por diante).

Segundo ainda esta visão mais econômica do cenário envolvendo o medo do crime, Semmens (2007), tratou do custo intangível do medo do crime, entendendo ser necessária a separação de dois elementos diferentes (mas relacionados) do custo do medo e como lidar com ele. É importante reconhecer, segundo a autora, que tanto para a vitimização direta quanto para a vitimização indireta, existem duas "manifestações" que em uma visão mais avançada podem ser traduzidas como "custos" (p. 231): respostas emocionais (que podem resultar em danos para a saúde física ou mental) e respostas comportamentais (que podem resultar em estratégias de evitação ou métodos de autoproteção). Semmens (2007) rememora que as respostas emocionais são relativamente bem exploradas na literatura, enquanto as respostas comportamentais estão menos avançadas. As pessoas podem ser forçadas a mudar a maneira como vivem suas vidas diárias, a fim de lidar com o medo do crime. As alterações no estilo de vida podem, então, resultar em flutuações na qualidade de vida (Hale, 1996).

Ainda na verificação destas influências no nível macro, Dowds e Ahrendt (1995) forneceram evidências de que a percepção de que o mundo estava mudando de maneira indesejada e de que as mudanças sociais experimentadas não eram bem vindas, relacionando tais mudanças ao medo do crime. Em que pese o trabalho destes pesquisadores estar aprofundado em um contexto mais amplo de autoritarismo, Dowds e Ahrendt (1995) argumentam que o medo do crime pode ser entendido como o medo da mudança social e da desintegração da sociedade. Tais crenças, assim como outros entendimentos similares (e.g. Taylor e Jamieson, 1998), voltam a atenção para o uso político do medo do crime. 
Jackson (2004) encontrou em um amostra do nordeste da Inglaterra, primeiramente, um conjunto de atitudes sociais e políticas que influenciaram a identificação da desordem respondentes que tinham opiniões mais autoritárias sobre a lei e a ordem e a sua aplicação, e que estavam preocupados com a deterioração a longo prazo da comunidade, foram mais propensos a perceber desordem no seu ambiente, pois eles também eram mais propensos a associar esses sinais físicos com problemas de coesão e consenso social, do declínio da qualidade dos laços sociais e de controle social informal - e, em segundo lugar, que as preocupações sobre tal desordem influenciaram fortemente o medo do crime.

Alguns estudiosos procuraram explicar por que o medo do crime se tornou tão incrustado na cultura vivida e prática das pessoas e das organizações (Hope \& Sparks, 2000), embora tenha havido discordância acerca dessa posição, como no caso de McConville e Shepard (1992) que verificaram não ser o medo do crime uma característica tão proeminente na vida da maioria das pessoas, acrescentando que "se ele está presente em tudo, é uma consideração de fundo" (p. 59). A posição mais presente, entretanto, é a de que o medo tornou-se uma preocupação cada vez mais forte na vida das pessoas, tanto que Garland (2001, p. 198) esclarece que existem "estratégias de responsabilização" que fazem com que o crime permaneça em posição de destaque na mente das pessoas, em vista desta transferência de responsabilidade do controle do crime de instituições formais para os indivíduos, para outras organizações e para o uso de produtos e serviços de segurança comerciais, este último estabelecido como a "mercantilização da segurança", nos dizeres de Loader (1999, p. 388).

\subsubsection{Conexão de ansiedades relacionadas ao crime com outros tipos de ansiedade}

O entendimento de que o medo do crime é capaz de expressar outros tipos de ansiedade não é novo. Garofalo e Laub (1978) já afirmavam que o medo do crime, ou que o foi medido e conceituado deste modo, tem suas raízes em algo mais abstrato, bem menos 
concreto do que a ameaça de algum perigo específico no ambiente imediato (ver também Bursik \& Grasmick, 1993; Merry, 1981; Smith, 1986). Parcialmente tomando esta noção com seriedade, e em parte respondendo a um largo corpo derivado e não teórico de determinadas pesquisas, uma série de estudos qualitativos foi conduzida por criminologistas e sociólogos na década de 1990 (Farrall et al., 2007).

Loader, Girling, e Sparks (2000) argumentaram que o sentimento público voltado ao crime está embebido pelo ambiente em que as pessoas vivem e convivem cotidianamente. Os autores chegam a afirmar que a conversa cotidiana das pessoas sobre crime e a ordem pública (sua intensidade, os vocabulários mobilizados, as associações que são feitas) ajudam na construção do sentido de lugar dos indivíduos, ou seja, a percepção e construção social acerca do seu local de moradia passa, naturalmente, pela construção social acerca de tópicos relacionados ao crime e à (des)ordem pública. Tanto o é, que este entendimento assume a forma de histórias e anedotas que constroem, em conjunto com outros elementos, a biografia, o desenvolvimento da comunidade, a percepção de mudança local/nacional e de declínio. Tais histórias servem para as pessoas construírem e adquirirem um sentido, não apenas voltado ao crime, mas do próprio lugar em que vivem (Girling, Loader, \& Sparks, 2000).

Outros estudos qualitativos analisaram como os indivíduos consolidam "mapas mentais" das localidades que são usadas tanto para representar quanto para evitar determinadas áreas (e.g. Ditton, Khan, \& Chadee, 2005; Lupton \& Tulloch, 1999; Taylor, 1996; Taylor \& Jamieson, 1998), quanto para desenhar as representações sociais acerca dos habitantes e passantes de determinados espaços públicos. Taylor, Evans e Fraser (1996) sugerem que as precauções referentes à localidade e representações dos potenciais criminosos, incluídas nos "mapas mentais" (p. 39) dos indivíduos, são construídos e compartilhados por moradores de um mesmo bairro ou vizinhança. O trabalho de Smith 
(1986) chega a conclusões semelhantes, sugerindo que a informação relacionada com o crime flui mais facilmente entre pessoas mais próximas, social e espacialmente falando.

Assim como os estudos examinaram os significados culturais de crime, especialmente com respeito ao modo como os sujeitos percebem suas próprias e as vizinhanças de outros bairros, a pesquisa qualitativa também investigou a relevância e a forma com que acontecem as relações sociais e percepções a respeito de outrem. Young (1999) observa que se vive em uma época de grande mobilidade, por isso há cada vez menos conhecimento direto sobre aqueles que rodeiam de maneira próxima os indivíduos (como no caso dos vizinhos) e, em uma sociedade mais social e culturalmente diversa, isso pode levar a uma menor previsibilidade do comportamento.

Lupton e Tulloch (1999, p. 509) defendem a importância da figura do "estranho imprevisível" e de como ele pode trazer repercussões no cotidiano individual e coletivo. Cohen (1972) trabalha figura extremamente similar, nomeando-o de "demônio popular". De maneira próxima, os autores remetam ao ente que simboliza a incerteza: como as pessoas não conhecem o estranho, não podem avaliar como este pode responder ou agir (ele, porque a figura deste estranho nas pesquisas é sempre ligada a um homem). Este estranho potencializa o medo nas pessoas quando passam por espaços públicos, pois os indivíduos sentem que possuem menos controle sobre este objeto social quando estão em público do que em suas próprias casas. De maneira mais clara, é mais fácil encontrar um estranho na rua do que em sua própria casa.

Evans, Fraser, e Walklate (1996), aproximaram-se do medo do crime por meio da apreciação de manifestações de confiança em uma determinada comunidade. Os moradores argumentam que suas rotinas são gerenciadas a partir do entendimento mais claro de em quem, quando e em que circunstâncias se pode confiar, o que estabelece que ser visualizado como integrante de uma determinada vizinhança, ser visto como "local", cria uma sensação 
de segurança voltada à vitimização. Ademais, estar familiarizado com a vizinhança indica quem são os indivíduos que representam segurança para uma cooperação. Por outro lado, o medo do crime pode resultar na mudança de atitudes em relação à incerteza e ambiguidade do comportamento humano, o que pode acontecer com um movimento que possibilite ver os outros como ameaças e representações do crime (Furedi, 1998).

Complementam ainda o desenvolvimento do trabalho sobre o medo do crime discussões de trabalhos que tomam como ponto de partida as ideias que emanam da psicanálise. Em poucas palavras, os trabalhos voltados a esta área do conhecimento argumentam que todos os indivíduos sofrem de ansiedade, e que essa ansiedade vem de uma variedade de fontes. Os indivíduos precisam defender-se contra estas ansiedades e isso, muitas vezes, significa que os indivíduos são atraídos para os discursos que oferecem maneiras de controlar estes sentimentos (Lupton, 1999).

No entanto, as maneiras pelas quais as pessoas são atraídas para diferentes discursos e as razões para serem atraídas para um discurso em vez de outro são, em parte, dependentes de experiências que tiveram e de suas próprias biografias pessoais (Hollway \& Jefferson, 1997). Como tal, argumentam Hollway e Jefferson, o medo do crime é "um deslocamento inconsciente de outros medos que são muito mais intratáveis" (1997, p. 263). Dessa forma, as ansiedades que talvez não possam ser devidamente identificadas ou totalmente compreendidas pelo indivíduo em questão são projetadas em alguma ansiedade conhecida ou de nomenclatura existente - neste caso, o medo do crime.

Hirtenlehner e Farrall (2013) tratam do que vem sendo escrito sobre a ligação de ansiedades sociais e medo do crime, afirmando que os trabalhos que se baseiam no pressuposto de que os medos e ansiedades gerados por processos de transformação social podem ser traduzidos em medo do crime, o qual, em essência, torna-se um meta-símbolo para os problemas sociais e patologias da vida na modernidade tardia. Mudanças sociais, 
econômicas e políticas profundas proporcionam o terreno fértil no qual os sentimentos relacionados com o crime de insegurança podem florescer. No entanto, que os medos são ligados ao crime, e através de que tipo de mecanismos, é uma questão controversa.

Uma abordagem de insegurança generalizada, que é favorecida especialmente - mas não somente - nos países que falam alemão, criam uma ligação para o diagnóstico de um insegurança endêmica em uma modernidade tardia (Ewald, 2000; Hirtenlehner, 2008, 2011; Sessar, 2008; Walklate \& Mythen, 2008). Seguindo a linha de argumentação desenvolvida por Bauman (2006), Beck (1992), e Giddens (1991), supõe-se que a perda perceptível de títulos e certezas tradicionais, em todas as áreas da vida, encoraja uma sensação difusa de mal-estar, em que os vários riscos e inseguranças perdem sua singularidade e distinção, misturando-se em uma ameaça generalizada.

\subsubsection{Outras classificações}

Alguns autores, no intuito de aprofundar a discussão teórica referente ao constructo, buscam classificá-lo e entendê-lo a partir de diferentes aspectos e contextos, o que torna mais assimilável a leitura e aplicação da variável medo do crime. A seguir, são expostas algumas destas classificações.

\section{1) Tipo e Tema de Vitimização}

Rountree e Land (1996) afirmaram que os investigadores têm geralmente ignorado as distinções potencialmente importantes entre os tipos e as dimensões do medo do crime. Neste caso, duas dimensões relacionadas ao constructo são identificadas: uma relativa ao tipo de vitimização (crimes dirigidos contra a pessoa ou contra a propriedade) e a segunda sobre o tema da vitimização (pessoal ou altruísta). O medo do crime pessoal foi distinguido com medo de crimes contra a propriedade por Ferraro e LaGrange (1992). Níveis de medo e 
reações ao medo irão variar consoante a ameaça de dano físico da vitimização, direcionada à pessoa ou a uma propriedade (Garofalo, 1981). Por isso, é essencial que o tipo de vitimização (pessoal ou propriedade) ser especificado em estudos medo do crime.

Warr (1984) usou um conjunto alternativo de indicadores que avaliaram o medo por 16 tipos específicos de vitimização entre os moradores de Seattle e descobriu que havia diferenças de idade significativas em apenas cinco casos. Não havia, segundo Ferraro e Lagrange (1992), nenhum estudo que diferenciava entre os tipos de crime e estabelecia os idosos como o grupo de maior medo em todos os tipos de crime. Em seus achados, Ferraro e Lagrange (1992) constataram que dada a variedade de métodos e estratégias utilizadas para detectar os efeitos da idade, uma conclusão é inevitável: as pessoas mais velhas não são mais propensas a ter medo do crime do que os outros grupos etários. $\mathrm{Na}$ verdade, para crimes contra a propriedade, por exemplo, os adultos mais velhos foram os que apresentaram os menores níveis de medo de todas as faixas etárias.

A maioria dos pesquisadores que estudam o medo do crime focam medo pessoal, ou medo voltado a si mesmo e encontram que o medo não é universalmente distribuído em resposta à probabilidade de ocorrência de crimes (Ferraro, 1995; Garofalo, 1981; Lewis \& Salem, 1986; Skogan \& Maxfield , 1981; Stafford \& Galle, 1984; Warr \& Stafford, 1983). Snedker (2006) rememora que, no entanto, o medo pela segurança e bem-estar dos outros é um componente frequentemente negligenciado do medo do crime: a maioria das pesquisas não faz uma pergunta separada sobre o medo voltado aos outros, visto que apenas alguns estudiosos realizaram a distinção entre o medo pessoal do crime e o medo altruísta do crime (Hollander, 2001; Madriz, 1997; Merry, 1981), e um número menor ainda utiliza este último como objeto distintivo de análise (Warr, 1992; Warr, \& Ellison, 2000) .

Warr (2000) foi um forte defensor do estudo sobre o medo altruísta do crime que, segundo ele, é predominante na sociedade. O autor afirma que os indivíduos podem não só 
temer por sua segurança pessoal, quando em um ambiente perigoso, mas também pela segurança de outros indivíduos que eles valorizam (normalmente pertencentes aos grupos mais próximos do indivíduo). Medo altruísta é definido, por Beck, Travis, e Lawrence (2004), como uma reação emocional ao perigo percebido de que um membro da família poderia ser vítima de um crime.

No entanto, também é provável que o medo altruísta se estenda para aqueles de fora da casa, estendendo-se às pessoas mais próximas da família e aos amigos, ou até mesmo ao público em geral, a depender do tipo de crime que está sendo analisado (Doran \& Burgess, 2012). Por tais motivos, torna-se indispensável que os pesquisadores distingam o medo pessoal (medo próprio, dirigido ao medo do próprio indivíduo ser vítima) do medo altruísta (medo voltados aos outros, de que pessoas próximas sejam vítimas) em suas investigações (Warr, 2000). Como estabeleceram Lewis e Salem (1986), refinamento dos vários tipos de vitimização (ou tipos de crime), neste sentido, é capaz de estabelecer melhorias abrangentes na clareza e resultados a serem alcançados.

Essa literatura estabelece que o medo altruísta do crime é um fator motivador importante no comportamento e no sentimento de segurança das pessoas, ainda que não tenha sido totalmente explorado ainda se, e como, o medo altruísta pode ser diferenciado, por exemplo, por gênero dos entrevistados. Essa ausência é estranha, porque um dos achados mais consistentes em pesquisa sobre medo pessoal do crime é o maior nível de medo relatado por mulheres, em comparação com homens (Ferraro, 1995, 1996; Fisher \& Sloan, 2003; LaGrange \& Ferraro, 1989; Skogan \& Maxfield, 1981; Stafford \& Galle, 1984; Warr, 1984; Young, 1992). Na verdade, devido ao seus maiores níveis de medo do crime e ao percebido nível de risco elevado com relação à agressão sexual, muitos estudos focam especificamente na tentativa de melhor compreender o medo das mulheres de crime (Madriz, 1997; Wesely \& Gaarder, 2004). Entretanto, tais diferenças níveis maiores de medo encontrado nas mulheres, 
por exemplo, também pode ser explicado pelas diferenças de gênero existentes quando se trata de medo altruísta do crime (Snedker, 2006).

2) Medo do Crime Disposicional e Situacional

A inclusão de características de disposição em qualquer estudo de vitimização foi considerada necessária (Schreck, Wright, \& Miller, 2002) desde que a pesquisa indicou que a probabilidade de vitimização varia drasticamente a partir das características pessoais das vítimas (Gottfredson, 1984; Schafer, 1968; Wolfgang \& Singer, 1978). Assim, alguns autores posicionaram-se no sentido de que seria essencial investigar a extensão em que as diferenças individuais aumentam ou diminuem a vulnerabilidade das pessoas à violência, juntamente com a sua exposição aos lugares, horários e pessoas consideradas de alto risco (Garofalo, 1987; Gottfredson, 1984).

A ideia de que variáveis psicológicas podem ser relevantes para a sequência de eventos que levam à vitimização de certas pessoas é tão antiga quanto os estudos vitimológicos em si (Mendelsohn, 1956; Schafer, 1968; Von Hentig, 1940; Wolfgang, 1958). Garofalo (1987), no entanto, foi um dos primeiros a incorporar as diferenças individuais em um modelo abrangente de vitimização pessoal. Quanto à introdução de modificações ao modelo original de estilo de vida/exposição pessoal, ele acrescentou "diferenças individuais" como um efeito direto sobre probabilidades de vitimização, independente dos efeitos das variáveis de estilo de vida. Como o autor afirmou, as pessoas diferem em suas propensões psicológicas em direção à assunção de riscos e nas imagens de vulnerabilidade física que projetam dirigidas aos potenciais infratores (Garofalo, 1987, p. 24).

Kodellas, Fisher, e Wilcox (2015) relatam que estudos indicam que, em ambientes profissionais, depois de manter constantes as atividades rotineiras dos funcionários, a probabilidade de vitimização deve ser maior para aqueles mais inclinados a assumir riscos, 
para aqueles que se apresentam como alvos "vulneráveis" para a exploração ou maus-tratos (p. 333) e, finalmente, para aqueles que têm uma disposição generalizada a experimentar altos níveis de emoções perturbadoras, como a raiva, hostilidade e medo (Aquino, 2000; Aquino \& Bradfield, 2000; Douglas \& Martinko, 2001).

Por outro lado, Lynch (1987) foi o primeiro a construir medidas de atividades rotineiras específicas para demonstrar sua importância na explicação do risco diferencial de vitimização no local de trabalho. Sua liderança foi logo seguida por outros pesquisadores, como Collins, Cox, e Langan (1987), que mostraram que certas atividades de trabalho, tais como viajar para fora da cidade e lidar face a face com os clientes, estão associadas ao risco de vitimização violenta e roubo no trabalho. Alguns anos mais tarde, Wooldredge, Cullen, e Latessa (1992) estenderam o trabalho anterior por meio da recolha de dados de funcionários, mais especificamente de professores universitários. Sua pesquisa mostrou que os conceitos de atividades rotineiras, como estar no campus depois de horas e aos sábados, foi responsável por maiores índices de vitimização violenta e de propriedade no local de trabalho. Além disso, Mustaine e Tewksbury (1997) usaram medidas de atividade de rotina, tais como a forma como uma pessoa viaja para o trabalho ou quantas vezes o trabalho envolve viagens durante a noite, para mostrar que as fontes de risco de vitimização no local de trabalho pode ser diferentes para trabalhadores masculinos e femininos.

De Coster, Estes, e Mueller (1999) refinaram e expandiram outras medidas de atividade de rotina, levando em consideração não apenas os padrões dos trabalhadores em atividade, mas também certas características da organização, como as normas de gestão e a proporção de homens para mulheres no local físico de trabalho (como uma medida de proximidade para infratores). Seus resultados mostraram que a proximidade, a atração e componentes de tutela da teoria da atividade de rotina são capazes de prever o assédio sexual dirigido às mulheres, no local de trabalho. Landau e Bendalak (2008) analisaram a violência 
contra o pessoal nas unidades de emergência de 25 hospitais gerais em Israel e mostraram que medidas de atividade de rotina, como ter acesso a um botão de emergência ou o número de pessoas autorizadas a acompanhar os pacientes, são capazes de explicar tanto a vitimização violenta como a de propriedade.

Gabriel e Greve (2003), ao destacarem a psicologia do medo do crime, notaram que seria importante distinguir conceitualmente entre os traços pessoais e o medo real como um estado afetivo momentâneo que varia dentro de uma pessoa de acordo com a situação a ela apresentada. Esta distinção foi introduzida por Catell e Scheier (1961) e elaborada mais profundamente por Spielberger $(1966,1972)$. Apesar de algumas dificuldades empíricas ), o raciocínio conceitual por trás dessa distinções parece claro, podendo ser aplicado para o medo do crime.

Os indivíduos podem ter medo de se tornar vítima de crime em situações como caminhar em um parque com luz baixa, falar com um estranho, e/ou ouvir um barulho estranho atrás deles. Neste sentido, o medo do crime é um estado transitório que geralmente passa rapidamente. No longo prazo, no entanto, essas ocorrências emocionais (Frijda, 1993) podem contribuir - especialmente se as experiências se repetem - à disposição geral dos indivíduos de temerem tornarem-se vítima de crime.

Em contraste, o medo do crime como uma disposição (traço) descreve tendência individual a experimentar o medo do crime em determinadas situações; é relativamente estável numa visão intrassujeitos, mas varia entre os indivíduos. Esta disposição individual é caracterizada pela experimentação de mais situações relevantes para o medo, sendo mais provável sentir medo em uma dada situação e, possivelmente, experimentar o medo de forma mais intensa. Portanto, pessoas com a citada disposição são mais propensas a experimentar o estado de medo (Spielberger, 1972). 
O medo do crime disposicional é um dos parâmetros que regula, influencia e determina a sua ocorrência real, isto é, o medo situacional do crime (como estado). Em princípio, o medo do crime disposicional também pode mudar dentro do sujeito. Entretanto, esta variabilidade não implica que o medo disposicional seja evocado ou dissipado por mudanças agudas no contexto situacional (Gabriel \& Greve, 2003). Estas mudanças, na visão dos autores, estão preferencialmente relacionadas com o medo situacional do crime, isto é, um processo dinâmico que tem um começo e um fim e que tem a duração de um comprimento de tempo específico. Em contraste, a mutabilidade do medo disposicional do crime reflete mudanças de desenvolvimento dentro da pessoa, como crescimento em coragem ou timidez. O medo disposicional do crime é o resultado de um processo de longo prazo, processo de desenvolvimento que é influenciado por condições pessoais e atributos (tais como ansiedade, tendências perceptivas e recursos de enfrentamento), por um lado, e pelas experiências individuais de relevantes situação de medo, por outro, bem como pela interação destes dois fatores.

A relação entre o medo disposicional do crime e o medo situacional do crime é conceitual: o medo disposicional é conceituada como a tendência do indivíduo de reagir "com medo". Como o medo (disposicional) do crime aumenta, o mesmo acontece, com constância similar, com a probabilidade de que determinadas situações que evoquem o medo do crime (como um estado). Em um determinado número de situações (suficientemente elevado), um indivíduo com um medo disposicional mais elevado vai experimentar o medo situacional da criminalidade com mais frequência. Se esse padrão de resultados não surge na pesquisa empírica, ou a disposição foi diagnosticada incorretamente ou situações consideradas não evocam suficientemente o medo de crime (Gabriel \& Greve, 2003).

Em se tratando de pesquisa empírica, um dos obstáculos mais significativos a serem ultrapassados - na visão de Hale (1996), Jackson $(2004,2009,2011)$, entre outros - é a 
realização de um enquadramento teórico mais preciso, que possibilite a mensuração mais adequada do fenômeno destacado. Possivelmente a discussão acerca dos fatores seja o ponto crucial do entendimento dos fatores, visto que estes servirão para definir o medo do crime, no que Pasquali (2010) ensina ser a "definição constitutiva" da pesquisa de extrema importância na construção de instrumentos de medida, por posicionarem o constructo exata e precisamente dentro de sua teoria (p. 173), e boas definições constitutivas possibilitam avaliar a qualidade do instrumento de medida e sua extensão semântica.

3) Medo do Crime: Variável bi ou tridimensional (a discussão do afeto e da cognição)

3.1) Variável bidimensional com foco no afeto

Na obra Colocando o Medo do Crime no Mapa, Doran e Burgess (2012), ao definirem medo do crime trabalham-no a partir de uma dimensão afetiva, afastando-o de qualquer influência cognitiva. De maneira mais específica os autores rememoram que grande parte do debate e da confusão em torno do conceito de medo do crime surge de uma falha em distinguir entre emoção (isto é, o que nós sentimos) e cognição (isto é, o que nós pensamos) (Ferraro, 1995; Warr, 2000). Definir o medo como uma emoção, é importante na visão de Doran e Burgess (2012), pois as respostas emotivas e cognitivas para o crime são conceitualmente diferentes, embora estejam relacionadas.

Assim, estudos confundindo os dois estados poderiam apresentar resultados marcadamente dissonantes e que não poderiam ser validamente comparados (Ferraro \& LaGrange, 2000; Rountree \& Land, 1996). De acordo com a definição de Ferraro e LaGrange (1987), o medo do crime consiste em "reações emocionais negativas" (p. 77). A emoção é um estado mental diferente, um estado de sentimento, que inclui respostas físicas capazes de incitar ou restringir os comportamentos dos indivíduos (Carlson \& Hatfield, 1992). 
Em contraste, alguns pesquisadores visualizam o medo do crime como uma avaliação cognitiva, abrangendo esta o julgamento das pessoas sobre o crime - sua avaliação de risco pessoal (ou seja, risco percebido) e sua preocupação geral sobre o crime (Skogan, 1999). Essa diferenciação foi primeiramente descrita por Ferraro e LaGrange (1987) ao argumentar que o medo do crime é estritamente uma resposta emocional. Eles projetaram uma taxonomia para diferenciar o medo do crime do risco percebido, com uma percepção do crime que formam um contínuo que abarca ambas as dimensões, visto que as percepções cognitivas dizem respeito a julgamentos de risco e as percepções afetivos relacionam-se a reações de temor. Os autores definem o conceito de medo do crime como sendo limitado à reação emocional decorrente do crime, ou os símbolos que uma pessoa se associa com o crime (Ferraro e LaGrange, 1987).

Uma construção frequentemente discutida na literatura do medo do crime envolve a adoção de ações comportamentais individuais para proteger-se do crime. Comportamentos restritos incluem comportamentos de esquiva (por exemplo, ficar em casa à noite) e comportamentos defensivos ou de proteção (por exemplo, possuir uma arma, a instalação de um alarme) (Ferraro \& LaGrange, 1987). Inúmeros pesquisadores examinaram o lugar de comportamentos restritos na formulação de medo do crime (Chan \& Rigakos, 2002; Ferraro, 1995; Hale, 1996; Keane, 1998; Liska et al., 1988; Mesch, 2000; Pain, 2001).

Essa inclusão do comportamento é relevante visto que, em uma primeira análise, poderia imaginar-se que o medo do crime foi pensado como uma variável unidimensional, voltada apenas para a emoção. Ainda que conscientemente muitos autores tenham imaginado esta possibilidade, as próprias perguntas existentes nas pesquisas de vitimização (ponto inicial da solidificação do medo do crime) demonstram o fator comportamental sempre presente - quando, por exemplo, perguntam se as pessoas evitam sair de casa à noite no bairro em que residem (Ferraro, 1995). Neste sentido, não há como visualizar 
unidimensionalidade no medo do crime (em tratando dos fatores emoção, cognição e comportamento), pois ao menos dois deles (emoção e comportamento) sempre foram considerados e estiveram presentes na literatura do assunto. Por isso, a discussão neste momento trata-se de uma divisão teórica acerca da existência de dois ou três fatores do medo do crime.

\section{2) Variável tridimensional}

Outros autores, por seu turno, percebem a presença das três dimensões - afetiva, cognitiva e comportamental - no medo do crime, estabelecendo a variável em uma visão mais completa. Jackson e Gouseti (2014), ao focarem a faceta comportamental, esclarecem que parece haver quatro categorias principais de respostas comportamentais à percepção do risco de vitimização e medo do crime: o comportamento de evitação, comportamento protetor, ajustes comportamentais e de estilo de vida, e participação em atividades coletivas relevantes (Miethe, 1995). Estratégias de prevenção incluem a minimização de seu contato com "locais de conflito" - bairros desfavorecidos, locais de entretenimento, parques, especialmente em determinados momentos - e com determinados tipos de pessoas - como estranhos, grupos de jovens, mendigos, entre outros -, bem como evitar atividades de rotina - viajar no transporte público, compras em lojas específicas, só para ilustrar.

Farrall, Jackson, e Gray (2009) constataram que uma boa proporção de indivíduos que disseram que estavam "muito" ou "bastante" preocupados também informou que eles não tinham "se preocupado sequer uma vez" nos últimos doze meses (p. 113). Momentos reais de medo ou preocupação eram raros, demonstrados pelo fato de que uma boa parte dos indivíduos que relataram alguma intensidade geral de preocupação não eram capazes de recordar uma única instância em que suas emoções tenham vindo à tona. Nestas circunstâncias, a ansiedade orientada para o futuro novamente parece ser a melhor descritora. 
Comportamento protetor, por sua vez, consiste basicamente em realizaçao de atividades que visem impedir ou resistir à criminalidade, como as medidas de prevenção situacional do crime (por exemplo, a instalação de alarmes, portas de bloqueio, aumentando a iluminação, possuir armas) e as atividades mais amplas de autoproteção (por exemplo, formação, autodefesa, viagem em grupos). Mudanças comportamentais e de estilo de vida incluem a retirada de atividades comuns que são considerados perigosas, tais como o uso de metrô à noite, frequentar determinados bares e outras atividades noturnas (Miethe, 1995). Finalmente, as respostas coletivas para o risco de crime abrangem a participação em grupos comunitários relevantes, como programas de vigilância de bairro e de auto-ajuda ou grupos de apoio, para a promoção dos programas de vítimas e testemunhas, e as iniciativas legislativas relacionadas.

Como nos estudos sobre as emoções das pessoas sobre o risco de crime, os estudos sobre estratégias comportamentais têm enfrentado desafios metodológicos (Regnifo e Bolton, 2012). Os autores inclusive perguntam se o comportamento representaria não apenas uma consequência, mas também uma causa das respostas emocionais ao risco de crime. Por exemplo, a restrição do comportamento social (devido aos baixos níveis de segurança percebida) pode criar o chamado ciclo de feedback ("feedback loop"), pelo qual mais medo leva a uma maior marginalização e, posteriormente, os maiores índices crimianis levam a níveis de medo ainda mais elevados (Liska et al., 1988).

O tipo de comportamento pode também importar para esse assunto. Ao diferenciarem os padrões gerais de comportamento ao longo dos domínios voluntário e obrigatório, Regnifo e Bolton (2012) constataram que as atividades de rotina foram correlacionadas com a variação nas avaliações cognitivas de risco de vitimização e desordem, e que estas duas construções previram padrões de comportamento em diferentes direções, ou seja, atividades 
voluntárias mais frequentes estavam ligadas ao aumento da sensação de risco de criminalidade e menores níveis de desordem percebida.

O fator cognitivo do medo do crime refere-se a avaliações cognitivas das pessoas de ameaça e de risco pessoais (Jackson \& Gouseti, 2014). O trabalho criminológico mostrou que a percepção do risco de vitimização é fortemente correlacionada com os níveis expressos de medo sobre o evento ocorrido (Ferraro, 1995; Farrall et al., 2009). Mas uma série de estudos também têm demonstrado a importância do nível de gravidade das consequências para as pessoas "se elas eram vítimas" e o senso de controle "sobre a ocorrência" dos crimes para os indivíduos (Jackson, 2009, p. 372). O medo pode, desta maneira, ser gerado e sustentado por um sentido de risco, ameaça e vulnerabilidade que é composto por probabilidade percebida, consequência percebida e controle percebido (Farrall et al., 2009; Gabriel \& Greve, 2003; Hale, 1996; Jackson, 2009, 2011; Killias, 1990).

Warr (1987) examinou as relações entre probabilidade percebida, seriedade percebida do crime e níveis expressos de medo do crime, concluindo que a percepção da gravidade de um determinado crime combinado com probabilidades subjetivas de sua ocorrência, ou seja, “sensibilidade para o risco", é capaz de prever fortemente o medo (p. 34). Além disso, Jackson (2011) descobriu que, quando os indivíduos perceberam ser o crime grave no seu impacto pessoal, e que eles têm pouco controle pessoal sobre o evento criminal que ocorre, um menor nível de risco percebido era necessário para estimular a preocupação sobre o crime.

O modelo teórico proposto por Gabriel e Greve (2003) expõe claramente a divisão tripartite presente na teoria atitudinal, salientando que as três dimensões fazem parte do constructo, e lembrando que o risco percebido ou a percepção de risco se relaciona, de maneira indubitável, à dimensão cognitiva do medo do crime. Jackson e Gouseti (2014) reforçam que o medo do crime é expansivo, porque a distinção ABC (affect, behavior e 
cognition) entre afeto, cognição e comportamento captura múltiplas dimensões do medo do crime, visto ser este um constructo multifacetado. De maneira sucinta, Gabriel e Greve (2003) consideram o afeto, a cognição e o motivo como condições necessárias para que um estado seja rotulado como medo. Se este estado for diagnosticado corretamente, todos os três componentes terão que ser dados, isto é, terão excedido um patamar limiar. O medo, nesta construção, seria então composto de:

- percepção cognitiva do indivíduo em relação à ameaça $(\mathrm{C})$;

- uma experiência afetiva correspondente (A); e

- uma motivação ou tendência de ação adequada (M).

Assim, os autores sugerem uma investigação a fim de constatar se esses três componentes $(\mathrm{C}, \mathrm{A}, \mathrm{M})$ podem ocorrer de forma independente e, em caso afirmativo, se outras combinações também podem ser rotuladas de medo. A Tabela 1 apresenta todas as combinações das três facetas, cada uma com uma descrição do estado atribuído, e somente a oitava e última combinação -+++- encarna um exemplo típico ou paradigmático de medo do crime.

Tabela 1

Combinações $C-A-M$ e estado atribuído $\mathrm{C}$ : percepção cognitiva do indivíduo em relação à A: sensação M: tendência de medo de ação Estado atribuído ameaça

(1)

(2)

$-$

(1)

$+$

)

$-$

$+$

$-$

\section{$=$ Sem medo}

Apatia: esta situação deve realmente me ameaçar porque é perigosa; é estranho, mas eu não me importo e não tenho nenhuma inclinação para realizar qualquer ação

Ansiedade de livre flutuação 
(4)

(5)

(7)

(8)

\begin{tabular}{|c|c|c|c|}
\hline- & - & + & $\begin{array}{l}\text { Comportamento cauteloso que não é } \\
\text { motivado por avaliações reais ou } \\
\text { emoções } \\
\text { (por } \\
\text { comportamento que se tornou } \\
\text { rotineiro ou comportamento de } \\
\text { reflexo) }\end{array}$ \\
\hline+ & + & - & $\begin{array}{l}\text { Esta combinação pode ser melhor } \\
\text { ilustrada por alguns 'casos ímpares', a } \\
\text { saber: 1) paralisado com susto, 2) } \\
\text { bravura, 3) impotência, 4) pesadelo }\end{array}$ \\
\hline+ & - & + & $\begin{array}{l}\text { Alguém se comporta 'com medo' em } \\
\text { vista de uma ameaça percebida, mas } \\
\text { 'mantém-se frio' (por exemplo, um } \\
\text { guarda-costas bem treinado e } \\
\text { experiente) }\end{array}$ \\
\hline
\end{tabular}

Ataques de pânico, fobia

$=$ Medo do crime

Fonte: Adaptado de Gabriel e Greve (2003)

Analisando a tabela, torna-se possível deduzir que, se o pressuposto teórico adotado é que $(\mathrm{C}+\mathrm{A}+\mathrm{M}$ é uma condição necessária para o estado de medo $)$ e se o estado em questão é o medo (deixando aberta a questão de como isso seria medido), então combinações diferentes de '+++' são impossíveis. Assim, se o estado é medo, a 'ocorrência incompleta' (no sentido de que um dos componentes está faltando) meramente indica problemas de avaliação.

Gabriel e Greve (2003) enfatizam que um indivíduo sentirá o medo momentâneo do crime sem refletir sobre estas 'dinâmicas cognitivo-avaliativas' complicadas, que são cobertas ainda por situações capazes de provocar o medo. Uma situação ameaçadora combina expectativas (anteriores), uma consciência real, avaliação, atribuições, avaliações, bem como o afeto e tipicamente - como um indicador e sinal externo do estado de medo do crime comportamento visível. 
Ressalta-se que nesta dissertação o medo do crime é entendido como uma avaliação psicológica do indivíduo em relação ao crime, uma organização de crenças em torno deste objeto (o crime), predispondo o indivíduo a estabelecer algum tipo de resposta, sendo estabelecido pelos aspectos afetivo, cognitivo e comportamental integrantes da teoria tripartite.

Em busca do já ressaltado entendimento mais completo do atributo para estabelecer critérios adequados de emprego empírico deste (Pasquali, 2010), torna-se relevante verificar além de sua dimensionalidade (estrutura interna) as relações que são estabelecidas com outras variáveis (preditoras e dependentes), complementando o conhecimento acerca das fronteiras que não podem ser ultrapassadas e daquelas que devem ser atingidas. Neste sentido, os valores humanos individuais estabelecem-se como fonte importante no desenvolvimento da pesquisa, em vista de seu poder preditivo sobre significativa diversidade de variáveis, de caráter comportamental, atitudinal, que é o caso desta pesquisa, e várias outras.

\subsection{Valores Humanos Individuais}

\subsubsection{Panorama histórico e conceitual}

O tema Valores aparece ao longo da história já nos idos da Grécia Antiga, quando Aristóteles os define como aquilo que todos desejam em contraponto ao que deveriam desejar. Neste sentido, o foco apontava para a realização de uma natureza, em vista da necessidade do ser humano desenvolver-se, de maneira virtuosa, na sua razão, o modo pelo qual a pessoa consegue encontrar-se, ser ela mesma (Aristóles, 350 a. C./2001).

Interessante a colocação encontrada em Paulino (2006) sobre o desacordo na definição de valores ao comparar Sócrates, Platão e os sofistas, visto que o primeiro determina a validade universal do valor, por este sofrer apreciação de um juízo de verdade. Os sofistas, por sua vez, trazem subjetividade e relatividade aos valores, determinando que 
estes são imprescindíveis para o ser humano, influenciados pelas "coisas que são e as que não são". Finalmente, Platão - mestre de Aristóteles - demonstra sua preocupação da busca pela verdade através de princípios da racionalidade, em vista da limitação em captar a realidade de todo o ser humano, permitindo esta racionalidade a aproximação com valores supremos, sendo eles: o eterno, o imutável, as essências e as ideias.

No panorama contemporâneo, por seu turno, Kant (1788/2002) agrega valores e normas ao afirmar que valor é o dever ser de uma norma, a qual não poderia expressar apenas sentido prático, devendo estar eivada de verdade, bondade e beleza às coisas julgáveis. Esta posição que, segundo Goergen (2005), foi seguida por muitos filósofos, admite o valor como uno, universal e eterno, estando presente no homem e em suas atividades e demonstrando indiferença, inclusive, ao mundo real.

Conforme destaca Ros (2006), a obra O campesino polonês, de Thomas e Znaniecki (1918), pode ser considerada um marco por diversos aspectos, entre os quais cabe ser destacado, para a psicologia social, a introdução dos conceitos de atitudes e valores, no intuito de diferenciá-los, como também a relação existente entre ambos. As atitudes, segundo os autores, podem ser entendidas como o significado dos objetos ou coisas para as pessoas, individualmente, apresentando, portanto, natureza intrassubjetiva; valores, de outra feita, precisam ter seu significado partilhado pelos demais membros de um determinado grupo social, demonstrando-se intersubjetivos.

A teoria da ação social, traçada por Parsons e Shils (1951), é outro ponto relevante no desenvolvimento da concepção que atualmente prevalece acerca de valores na psicologia social. A ação motivada de Parsons (1937) guarda ligação direta com o enquadramento de valores como princípios motivacionais, visto que naquela a ação encontra lugar no momento em que o indivíduo busca o alcance de metas, enquanto nestes, a realização de um valor procura representar uma meta motivacional subjacente (Schwartz \& Bilsky, 1987; Schwartz, 
1992). Parsons (1959) preocupa-se em definir valor, delimitando-o como elemento simbólico compartilhado, servindo de critério determinante na escolha de alternativas, abertas de um contexto ou situação, que orientam o indivíduo.

A antropologia encontra representação na temática em Kluckhohn (1951), que define valor como princípio desejável: “concepção, explícita ou implícita, própria de um indivíduo ou característica de um grupo, acerca do desejável, o que influencia a seleção dos modos, meios e fins de ações acessíveis" (Kluckhohn, 1951, p. 473). Este conceito é bastante relevante, particularmente quando o autor complementa a arguição com a orientação de valor, sendo esta uma concepção influente na conduta, nas relações humanas e na dicotomia desejável-não desejável, verificadas as relações intersujeitos e entre estes e o ambiente circundante. Esta orientação para os valores de princípios do desejável encontram terreno fértil e longevo, como pode ser verificado na definição atribuída por Schwartz (1992), que assevera serem os valores acepções ou crenças, pertinentes a estados ou comportamentos desejáveis e responsáveis por guiar escolhas ou seleções de comportamentos.

Ao retornar o olhar para o campo da psicologia, constata-se a colaboração de Lewin (1942) para a consolidação da definição do constructo, ao observar a ligação entre valores e comportamento, em específico a influência daqueles neste, determinando grau de relevância (e de prioridade) nas ações, com aplicação de indicação positiva ou negativa, num determinado contexto. Allport (1961), além de sugerir que os valores exercem um domínio significativo na vida das pessoas, direcionando a atividade do ser humano às suas realizações, também critica a falha dos psicólogos em constatar que as prioridades impostas pelos valores humanos influenciam a percepção da realidade (Allport, 1955), em consonância com o posicionamento de Lewin (1942).

É cabível citar neste mesmo panorama o psicólogo Abraham Maslow, que voltou sua teoria às necessidades humanas, não deixando, entretanto, de abordar em sua teoria a estreita 
relação entre tais necessidades e os valores, hipotetizando inclusive acerca da possibilidade de identificar valores basilares ou essenciais do ser humano ao perguntar para indivíduos com vivência de experiências positivas sobre seus valores (Maslow, 1971). O autor chegou a definir os valores a partir do distanciamento entre estes e estados "puramente emocionais" (p. 134), em vista de sua natureza também cognitiva, adicionando também como seus pacientes relatam os valores como características verdadeiras e autênticas, capazes de "iluminar" o estado de cegueira prévia da realidade.

Rokeach (1973) tornou-se pedra fundamental para os modelos de valores que viriam anos ou décadas mais tarde (como os de Inglehart, 1997 e de Schwartz, 1992), além de proporcionar contribuições teóricas referentes: (i) à classificação dos valores como instrumentais e terminais, com seus subtipos correspondentes; (ii) ao desenvolvimento do método de autoconfrontação, no intuito de possibilitar mudança dos valores; e (iii) à propositura de ideologia política com combinação de pontuação para determinados valores. Para Rokeach (1973), o número total de valores de uma pessoa é relativamente pequeno, todas as pessoas apresentam valores idênticos - variando tão somente na intensidade - e são organizados de maneira sistêmica. Também, segrega os valores em terminais, nomeados assim por caracterizarem estados finais de existência (pessoais e sociais), e em instrumentais, que determinam modos de conduta (de competência e morais, com características intra e interpessoais, respectivamente).

Tais teorias e outras (e.g., Feather, 1995; Morris, 1956) foram fundamentais para o desenvolvimento do modelo teórico que seria adotado posteriormente por Schwartz e Bilsky (1987, 1990), e consolidado pelo próprio Schwartz (1992, 2006), o qual foi sendo desenvolvido e utilizado em diversos estudos transculturais que são desenvolvidos até a atualidade. 


\subsection{Modelo Teórico dos Valores Humanos de Schwartz}

Schwartz e Bilsky (1987) definem valores, em que pese o grande número de definições já existentes à época, a partir de cinco características comuns à maioria dos conceitos de valores, a saber:

(i) são crenças, o que significa dizer que se ligam à emoção, com a ativação de sentimentos positivos ou negativos, a depender da situação em que se encontra o indivíduo. Um valor ao ser ameaçado, por exemplo, move a pessoa a um estado de alerta de maneira inconsciente;

(ii) agem sobre os estados finais ou comportamentos desejáveis, consolidando-os como um constructo motivacional, encaminhando os sujeitos aos objetivos ou metas que buscam alcançar (e.g. felicidade, realização, justiça, saúde);

(iii) transcendem situações específicas, diferenciando-os de constructos importantes como normas e atitudes, possibilitando um posicionamento dos indivíduos em diversos momentos e enredos de suas vidas, como nos relacionamentos, no trabalho, entre outros;

(iv) servem como guias na seleção ou avaliação do comportamento e eventos, complementa o item anterior, visto que apesar de transcender situações específicas, servem como guias para tais, pois qualificam posicionamentos e comportamentos como bons ou maus, justos ou injustos, legítimos ou ilegítimos, aceitáveis ou inaceitáveis, na medida em que a situação, ação, pessoa ou contexto se desenvolva a favor ou contrariamente aos valores relevantes para o ser humano destacado; e

(v) são ordenados pela importância relativa, o que determina a ordenação de prioridades dos valores dos indivíduos, sendo alguns extremamente importantes, enquanto outros não tanto.

Em complemento à definição estabelecida, os autores elaboraram uma tipologia abrangente dos domínios de conteúdo de valores, com o pressuposto teórico de que os valores 
são representações cognitivas de três tipos de necessidades humanas universais: biológica do organismo, exigências sociais interacionais para a coordenação interpessoal e demandas institucionais sociais para o bem-estar e a sobrevivência do grupo.

Diante deste contexto, Schwartz e Bilsky (1987) apresentam sete domínios motivacionais, sendo eles prazer, realização, autodireção, maturidade, segurança, pró-social, conformidade restritiva, (e poder social - que não foi relatado no domínio teórico inicial, tendo sido encontradas evidências posteriores de sua existência), em que os valores são posicionados bidimensionalmente em um arranjo circular, com regiões que emanam de um centro comum. Esta forma de organização, também chamada de faceta polar, permite a polarização de valores que são opostos, conceitualmente falando e a dirimição do distanciamento entre valores que conservem características próximas, consoante a Figura 1.
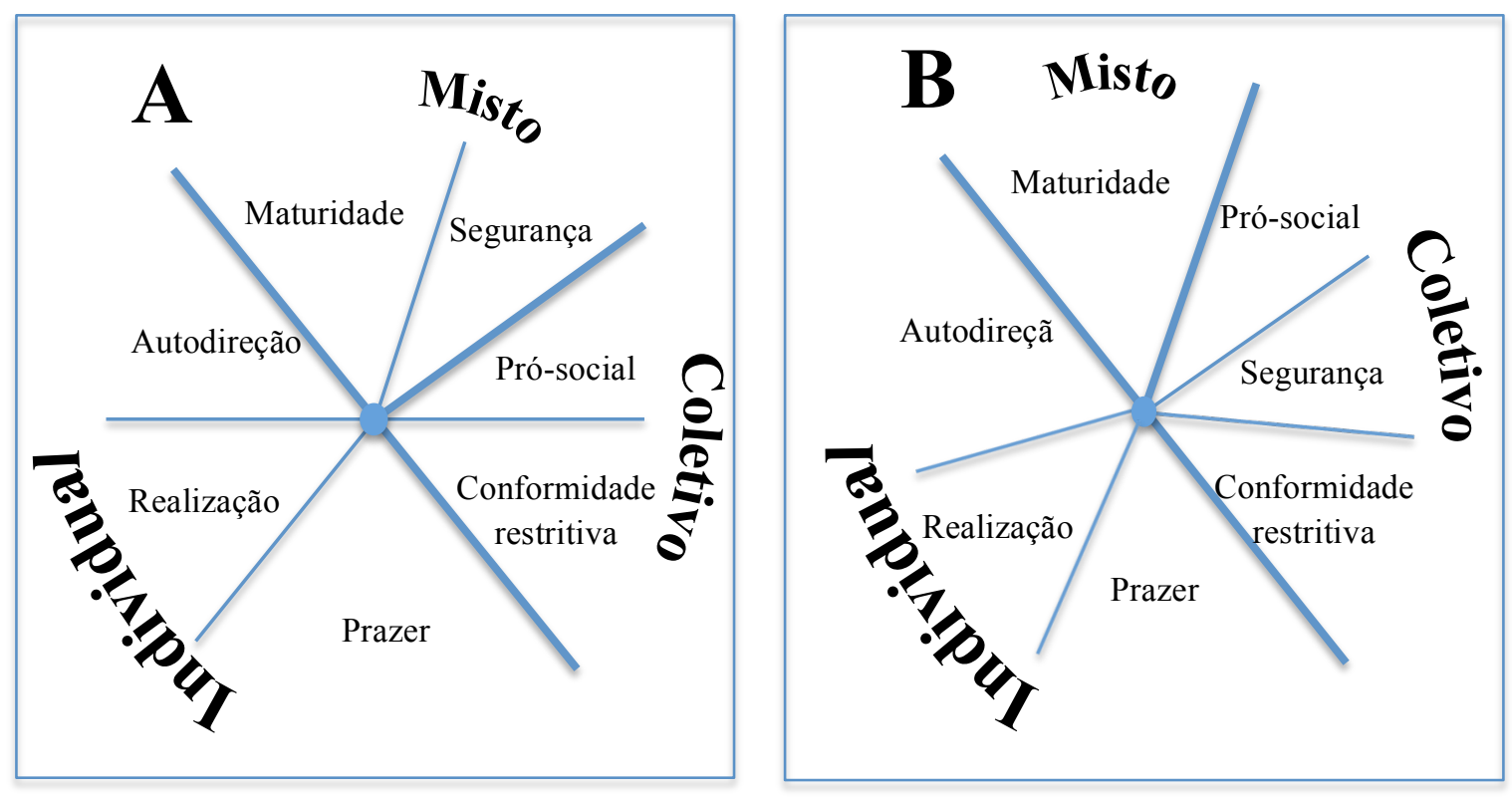

Figura 1. Representações alternativas das relações estruturais entre os domínios de valores hipotéticos.

Fonte: Adaptado de Schwartz e Bilsky (1987) 
Oportuno também demonstrar, através da Tabela 2, os sete tipos motivacionais contemplados por Schwartz e Bislky (1987), apoiados em Rokeach (1973), suas metas e como são compostos em termos de valores:

Tabela 2

Valores hipotetizados por Schwartz e Bislky, suportados pela teoria de Rokeach

\begin{tabular}{|c|c|c|}
\hline $\begin{array}{c}\text { Valores } \\
\text { Hipotéticos }\end{array}$ & Metas / Objetivos que definem os valores & Pertinente a interesses \\
\hline Prazer & Vida confortável, felicidade, alegria e prazer & Individuais \\
\hline Segurança & $\begin{array}{l}\text { Harmonia interior, segurança familiar, segurança } \\
\text { nacional e paz no mundo }\end{array}$ & Coletivos/Mistos \\
\hline Realização & Capacidade, ambição e reconhecimento social. & Individuais \\
\hline Autodireção & $\begin{array}{l}\text { Criatividade, ousadia, imaginação, independência, } \\
\text { capacidade intelectual e raciocínio lógico. }\end{array}$ & Individuais \\
\hline $\begin{array}{l}\text { Conformidade } \\
\text { restritiva }\end{array}$ & Obediência, educação, asseio e autocontrole & Coletivos \\
\hline Pró-social & $\begin{array}{l}\text { Utilidade e auxílio ao próximo, perdão, amor ao } \\
\text { próximo e igualdade }\end{array}$ & Coletivos \\
\hline Maturidade & $\begin{array}{l}\text { Sabedoria, tolerância, abertura a ideias, amor } \\
\text { maduro, contemplação da beleza, coragem (de } \\
\text { acordo com suas crenças) }\end{array}$ & Mistos \\
\hline
\end{tabular}

Fonte: Schwartz e Bislky (1987)

Mais tarde, Schwartz (1992) modificou a versão anterior da teoria de diversas maneiras. Primeiramente, foram obtidos três tipos motivacionais potencialmente universais de valores que foram mencionados apenas brevemente por Schwartz e Bilsky (1990), especificando-se os métodos para a sua medição. Em segundo lugar, desenvolveu-se a possibilidade de que a espiritualidade pode constituir outro tipo universal com características incomuns. Em terceiro lugar, com base em conclusões empíricas e em considerações conceituais, sugerimos modificações das definições e conteúdo de quatro dos tipos anteriores (prazer, maturidade, pró-social, segurança). Estas modificações visam clarificar os significados dos tipos, clarificando assim as suas origens em requisitos universais e suas relações com outros tipos de valores. 
A Tabela 3 descreve os dez tipos motivacionais contemplados na Teoria de Valores apresentada por Schwartz (1992), seus objetivos ou metas e como são compostos em termos de valores:

\section{Tabela 3}

Relação dos Valores Humanos de Schwartz

\begin{tabular}{lll}
\hline $\begin{array}{c}\text { Tipo } \\
\text { Motivacional }\end{array}$ & \multicolumn{1}{c}{ Objetivo ou Meta } & \multicolumn{1}{c}{ Exemplo de Valores } \\
\hline Autodeterminação & $\begin{array}{l}\text { Pensamento e ação independente, } \\
\text { escolher, criar, explorar. }\end{array}$ & $\begin{array}{l}\text { Criatividade, liberdade, escolha do } \\
\text { próprio destino, curiosidade, } \\
\text { independência, } \\
\text { privacidade. }\end{array}$ \\
\hline Estimulação & $\begin{array}{l}\text { Excitação, novidade, desafio na } \\
\text { vida. }\end{array}$ & $\begin{array}{l}\text { Uma vida diversificada, uma vida } \\
\text { excitante, ousadia. }\end{array}$ \\
\hline
\end{tabular}

Prazer ou gratificação sexual.

$\begin{array}{ll}\text { Hedonismo } & \begin{array}{l}\text { Valores de hedonismo são } \\ \text { derivados de necessidades }\end{array} \\ & \text { orgânicas e do prazer associado à } \\ & \text { sua satisfação. }\end{array}$

Prazer, vida prazerosa, autoindulgência.

Sucesso pessoal por meio de

Realização demonstração de competência de

Ambição, sucesso, capacidade de acordo com padrões sociais. influência, reconhecimento social.

\begin{tabular}{llcl}
\hline Poder & $\begin{array}{l}\text { Status social e prestígio, controle } \\
\text { ou domínio sobre pessoas e } \\
\text { recursos. }\end{array}$ & $\begin{array}{l}\text { Autoridade, saúde, poder social, } \\
\text { preservação da imagem pública, } \\
\text { reconhecimento social. }\end{array}$ \\
\hline Segurança & $\begin{array}{l}\text { Segurança, harmonia da e e } \\
\text { estabilidade da sociedade, dos } \\
\text { relacionamentos e de si mesmo. }\end{array}$ & $\begin{array}{l}\text { Ordem social, segurança familiar, } \\
\text { segurança nacional, reciprocidade de } \\
\text { favores, limpeza, saúde e senso de } \\
\text { pertencimento. }\end{array}$ \\
\hline
\end{tabular}

Restrição de ações, inclinações e
impulsos que tendem a chatear ou

Conformidade prejudicar outros e que violam expectativas ou normas sociais.
Obediência, autodisciplina, educação, respeito aos parentes e mais velhos.

\begin{tabular}{llll}
\hline \multirow{2}{*}{ Tradição } & $\begin{array}{l}\text { Respeito, compromisso e e } \\
\text { aceitação dos costumes e ideias } \\
\text { que a cultura ou a religião do } \\
\text { indivíduo fornecem. }\end{array}$ & $\begin{array}{l}\text { Respeito a tradições, humildade, } \\
\text { devoção, aceitação da vida que } \\
\text { possui, moderação. }\end{array}$ \\
\hline \multirow{3}{*}{ Benevolência } & $\begin{array}{l}\text { Preservar e fortalecer o bem-estar } \\
\text { daqueles com quem o contato } \\
\text { pessoal do indivíduo é mais } \\
\text { frequente (endogrupo). }\end{array}$ & $\begin{array}{l}\text { Lealdade, colaboração, perdão, } \\
\text { honestidade, responsabilidade, } \\
\text { amizade verdadeira, amor maduro. }\end{array}$ \\
\hline
\end{tabular}




\begin{tabular}{lll}
\hline & & $\begin{array}{l}\text { Tolerância e abertura a outras ideias, } \\
\text { justiça social, igualdade, mundo em }\end{array}$ \\
Universalismo & $\begin{array}{l}\text { Compreensão, agradecimento, } \\
\text { tolerância e proteção do bem estar } \\
\text { de todas as pessoas e da natureza. admiração pela beleza do }\end{array}$ & $\begin{array}{l}\text { paz, ando, unidade com a natureza, } \\
\text { sabedoria, proteção a meio me } \\
\text { ambiente. }\end{array}$ \\
\hline
\end{tabular}

Fonte: Schwartz (1992)

Ressalta-se que Schwartz (1992) teorizou um $11^{\circ}$ tipo motivacional, constituído pela espiritualidade, cujos objetivos seriam significado e harmonia interior através da transcendência da realidade cotidiana. A ideia de que os valores espirituais são um tipo universal, entretanto, suscita dois problemas. Em primeiro lugar, a busca de significado e coerência, como descrito por teólogos e filósofos, pode trazer um nível de sofisticação que supera o nível de envolvimento comumente estabelecido pelas pessoas. Em vez disso, a maioria das pessoas pode satisfazer necessidades de coerência por meio de valores como tradição, segurança e conformidade. Assim, a espiritualidade não pode servir de princípio orientador para todas as pessoas. Como segundo ponto, existem os significados diferentes e são manifestados de maneiras diversificadas - contato com o sobrenatural, unidade com a natureza, desapego de questões materiais e busca do eu, entre outros.

A organização dos tipos motivacionais continuou sendo uma preocupação no modelo desenvolvido por Schwartz (1992), com a organização polar proposta pelo modelo anterior (Schwartz \& Bilsky, 1987), ou seja, diferentes sistemas psicológicos predispostos por semelhanças e oposições, em formato de um continuum hierarquizado por motivações subjacentes. Essa estrutura decorre do fato de as ações, na busca de qualquer valor, produzirem consequências que poderiam conflitar ou ser congruentes com a busca de outros valores; assim, alguns pares de tipos motivacionais concorreriam entre si, enquanto outros seriam complementares (Schwartz, 2005).

A explicação do que são valores congruentes ou conflitantes foi trazida por Bardi e Schwartz (2003). Para esses autores, dois valores expressariam congruência quando as ações 
normalmente utilizadas para expressá-los fossem compatíveis com as metas motivacionais que representam. Por exemplo, benevolência e universalismo são valores congruentes, porque ambos promulgam ações relacionadas à promoção do bem-estar de terceiros. Desse resultado entre proximidade e distanciamento, determinados indivíduos apresentam alta aderência a tipos motivacionais compatíveis e baixa prioridade para tipos motivacionais incompatíveis. Ainda que não se possa refutar que as pessoas possam buscar valores diametralmente opostos, dificilmente o fariam para um única ação, pois caso este fato ocorresse, certamente surgiria o conflito (Schwartz \& Bilsky, 1990).

A estrutura circular proposta por Schwartz (1994, 2005), representada na Figura 2, refere-se ao parâmetro completo de conflito e de congruência entre os tipos motivacionais, apresentando ainda os tipos motivacionais de segunda ordem. A proximidade entre tipos motivacionais, independentemente da localização no círculo, reflete compatibilização de motivações subjacentes, enquanto o distanciamento no círculo reflete antagonismo ou incompatibilidade de tais motivações.

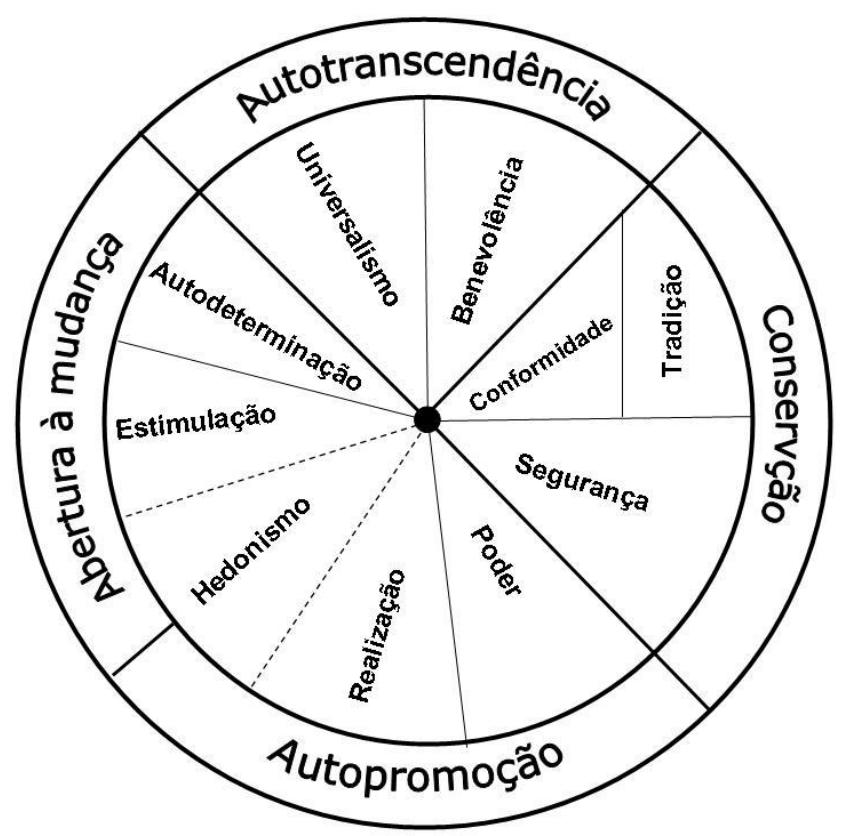

Figura 2. Continuum dos valores de Schwartz Fonte: Schwartz (2005) 
O potencial da teoria de Schwartz, e seu diferencial às demais proposituras ao estudo de valores, é a possibilidade de trabalhar de maneira dinâmica e integrada entre os tipos motivacionais (sejam eles compatíveis ou antagônicos), ao contrário do exame das relações entre valores isolados e atitudes ou comportamentos verificado em outras teorias. Este modelo torna mais plausível, inclusive, o entendimento de que dois ou mais valores podem atuar, conjuntamente, em uma determinada ação do indivíduo (Schwartz, 2005).

O modelo possibilita ainda, como explica Schwartz (1996), uma associação lógica entre os tipos motivacionais e uma determinada variável, possibilitando uma melhor predição e explicação dos resultados esperados e obtidos. Nesse sentido, espera-se que determinada variável que apresente alta correlação com um determinado tipo motivacional, decresça neste mesmo parâmetro à medida que ocorra uma verificação com os demais tipos motivacionais, no sentido horário ou anti-horário. Ademais, espera-se que o tipo motivacional oposto apresente uma correlação negativa, de acordo com a arguição já estabelecida. Entretanto, como externado pelo próprio autor (Schwartz, 1992), a divisão de espaço entre os tipos motivacionais é arbitrária, o que possibilita - e no posicionamento do autor era o que se esperava - uma outra divisão futura, uma teoria revista, "que indique valores discretos com maior heurística universal e poder preditivo" (p. 45).

Avançando ainda mais na teoria, Schwartz et al. (2012), propõem um refinamento na teoria dos Valores Humanos, objetivando um contínuo mais significativo, com maior confiabilidade entre os itens e menor multicolinearidade entre valores adjacentes. Acrescentam os autores que as pesquisas desenvolvidas ao longo dos 20 anos após a adoção do modelo anterior possibilitaram uma delimitação e divisão mais nítidas dos tipos motivacionais para um número maior de tipos, um total de 19, com maior qualidade de descrição. Partindo de exemplos como autodireção e segurança, que eram integrados por dimensões complementares na teoria dos 10 valores, Schwartz et al. (2012) verificaram que 
determinadas associações que haviam sido encontradas anteriormente eram explicadas mais fortemente (ou melhor, totalmente) por uma das facetas - pensamento e ação, no caso da autodireção; pessoal e social, no caso da segurança -, o que ratificou o entendimento da necessidade de refinamento da teoria.

Os autores estruturam a análise dos subtipos potenciais de cada um dos 10 em quatro etapas: (i) exame da definição conceitual do valor e verificação de existência de razões teóricas para desmembrar o valor em outros mais refinados; (ii) observação de itens no Instrumento de Valores de Schwartz (Schwartz Value Survey, SVS) e na Escala de Valores Humanos (Portrait Values Questionnaire, PVQ); (iii) avaliação de evidência visual para os valores refinados em mapas de escalonamento multidimensional (MDS); e (iv) verificação da evidência estatística para o desenvolvimento dos valores refinados em estudos de Análise Fatorial Confirmatória.

Análises de escalonamento multidimensional e confirmatórias dos 57 itens componentes do instrumento elaborado para mensurar esses valores resultaram em subsídios suficientes para a propositura de distinção e ordenamento entre os 19 tipos propostos na revisão. A Tabela 4, além de apresentar os 19 valores da teoria refinada e definir cada um em relação à meta motivacional expressa, demonstra os valores originários (pertencentes à teoria dos valores de Schwartz, 1992) dos valores refinados, dos quais cinco foram segmentados para o surgimento de 8 novos valores ( 2 facetas de autodireção, 2 de poder, 2 de segurança, 2 de conformidade, 2 de benevolência e 3 de universalismo), e dois foram criados (face e humildade). 
Tabela 4

Os 19 Valores da Teoria Refinada, definidos em termos de Metas Motivacionais, e seus valores originários

\begin{tabular}{|c|c|c|}
\hline Valor originário ${ }^{a}$ & Valor & Componentes da definição \\
\hline \multirow{2}{*}{ Autodireção } & $\begin{array}{l}\text { Autodireção de } \\
\text { Pensamento }\end{array}$ & $\begin{array}{l}\text { Liberdade para cultivar suas próprias ideias e } \\
\text { habilidades. }\end{array}$ \\
\hline & Autodireção de Ação & $\begin{array}{l}\text { Liberdade para determinar suas próprias } \\
\text { ações. }\end{array}$ \\
\hline Estimulação & $\begin{array}{l}\text { Autodireção de } \\
\text { Estimulação }\end{array}$ & Excitação, novidade e mudança. \\
\hline Hedonismo & Hedonismo & Prazer e gratificação sensual para si mesmo. \\
\hline Realização & Poder de realização & Sucesso de acordo com os padrões sociais. \\
\hline \multirow{2}{*}{ Poder } & Poder de domínio & $\begin{array}{l}\text { Poder pelo exercício de controle sobre outras } \\
\text { pessoas. }\end{array}$ \\
\hline & Poder sobre Recursos & $\begin{array}{l}\text { Poder pelo controle sobre materiais e } \\
\text { recursos sociais. }\end{array}$ \\
\hline$-----{ }^{b}$ & Face & $\begin{array}{l}\text { Manutenção da imagem pública e evitação de } \\
\text { humilhações. }\end{array}$ \\
\hline \multirow{2}{*}{ Segurança } & Segurança Pessoal & Segurança em seu ambiente imediato. \\
\hline & Segurança Social & $\begin{array}{l}\text { Segurança e estabilidade da sociedade (mais } \\
\text { ampla). }\end{array}$ \\
\hline Tradição & Tradição & $\begin{array}{l}\text { Manutenção e preservação da cultura, família } \\
\text { ou religião. }\end{array}$ \\
\hline \multirow{2}{*}{ Conformidade } & $\begin{array}{l}\text { Conformidade com } \\
\text { Regras }\end{array}$ & $\begin{array}{l}\text { Conformar-se com regras, leis e obrigações } \\
\text { formais. }\end{array}$ \\
\hline & $\begin{array}{l}\text { Conformidade } \\
\text { Interpessoal }\end{array}$ & Evitar chatear ou machucar outras pessoas. \\
\hline$------{ }^{b}$ & Humildade & $\begin{array}{l}\text { Reconhecimento da própria insignificância } \\
\text { em um contexto amplo. }\end{array}$ \\
\hline \multirow{2}{*}{ Benevolência } & $\begin{array}{l}\text { Benevolência } \\
\text { Dependência }\end{array}$ & $\begin{array}{l}\text { Ser um membro confiável e fidedigno do } \\
\text { endogrupo. }\end{array}$ \\
\hline & Benevolência Cuidado & $\begin{array}{l}\text { Devoção ao bem-estar dos membros do } \\
\text { endogrupo. }\end{array}$ \\
\hline \multirow{3}{*}{ Universalismo } & $\begin{array}{l}\text { Universalismo } \\
\text { Compromisso }\end{array}$ & $\begin{array}{l}\text { Comprometimento com igualdade, justiça e } \\
\text { proteção de todas as pessoas. }\end{array}$ \\
\hline & Universalismo Natureza & Preservação do ambiente natural. \\
\hline & $\begin{array}{l}\text { Universalismo } \\
\text { Tolerância }\end{array}$ & $\begin{array}{l}\text { Aceitação e compreensão daqueles que são } \\
\text { diferentes de si mesmo. }\end{array}$ \\
\hline
\end{tabular}

Fonte: Adaptado de Schwartz et al. (2012)

Nota ${ }^{a}$ Valor constante da teoria dos 10 valores (Schwartz, 1992).

${ }^{\mathrm{b}}$ Sem valor correspondente anterior. 
Consoante argumentação já realizada, a ordem circular do contínuo, proposta pela teoria original, baseia-se em proximidades ou distanciamentos motivacionais entre os tipos motivacionais (Schwartz, 1987, 1992). Lógica idêntica foi utilizada na teoria refinada, modelo que determina a proximidade ou compatibilidade entre pares de valores quando, por exemplo, um determinado comportamento expressa metas destes. Esta compatibilidade é refletida em uma proximidade no contínuo. O pensamento contrário, ou seja, quando um comportamento implica resultados opostos para pares de valores, resultando no enfoque da meta de um deles em detrimento da presente no outro, existe conflito e, por consequência, um distanciamento no círculo teórico. A Figura 3 ilustra este posicionamento dos 19 valores na estrutura circular da teoria refinada:

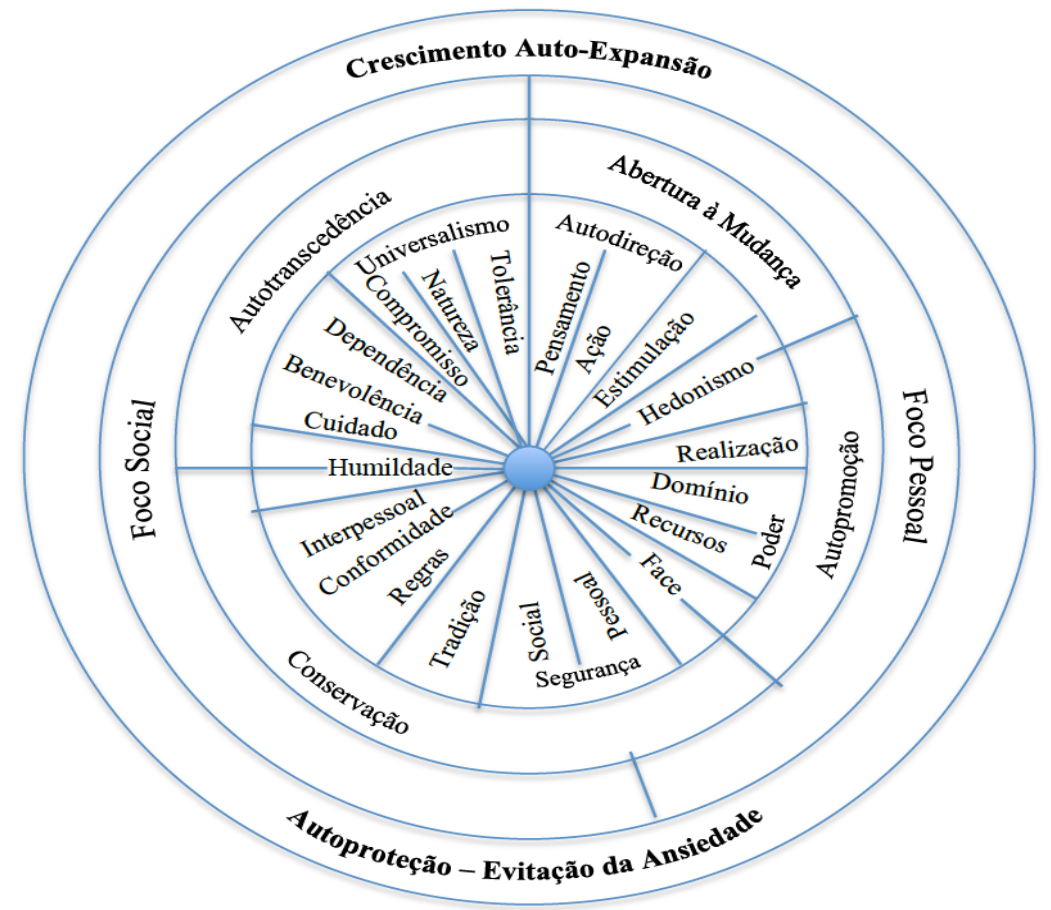

Figura 3. Continuum dos valores refinados de Schwartz Fonte: Adaptado de Schwartz et al. (2012)

Neste palmilhar, observa-se que a teoria refinada não invalidou a estrutura dos 10 tipos motivacionais elencados por Schwartz (1992), como esta última não o fez com o modelo de Schwartz e Bilsky (1987). O fato é que a estrutura proposta pela teoria refinada 
oportunizou um novo rearranjo, mantendo, entretanto, similaridade com o modelo proposto imediatamente antes desta.

\subsection{Aplicação da Teoria Refinada de Valores de Schwartz}

O aumento da segmentação do contínuo de valores proposta na teoria refinada de Schwartz et al. (2012) possibilita, segundo os autores, o avanço tanto da compreensão do domínio de valores, como da utilização de valores para estudar outros fenômenos. Simultaneamente, demonstra compatibilidade com as construções originais de 10 valores, visto que os 19 valores baseiam-se no mesmo contínuo motivacional circular presente na teoria original.

Tanto que os autores reforçam que a combinação de valores adjacentes no círculo da teoria refinada, deve possibilitar a recuperação dos 10 valores originais, ou ainda formar outros agrupamentos de valores úteis para o estudo de tópicos específicos. Tal flexibilidade possibilita também a adoção de combinações distintas de valores, a depender do contexto do estudo proposto, além de perpetuar as condições originais referentes ao quatro valores de ordem superior (Schwartz, 1992) - autotranscendência, abertura à mudança, autopromoção e conservação -, ou mesmo dois subconjuntos ainda mais abrangentes e propostos na teoria refinada (Schwartz et al., 2012) - valores de crescimento versus valores de proteção.

Para mensuração da teoria refinada Schwartz et al. (2012) discriminaram os 19 valores através de dados de 10 países - Finlândia, Alemanha, Israel, Itália, Nova Zelândia, Polônia, Portugal, Suíça, Turquia e Estados Unidos -, contemplando amostras de adultos e estudantes universitários, examinando as associações preditivas com um conjunto de atitudes e crenças. Os respondentes apresentaram diferentes ocupações e níveis de escolaridade, entretanto a maioria apresentava escolaridade e nível socioeconômico relativamente altos. Os autores incluíram como limitação da pesquisa a avaliação da teoria com amostras de menor 
nível socioeconômico, em países com menor perfil socioeconômico e em regiões do mundo ainda não estudadas (e.g., África Subsaariana, extremo Oriente e América Latina).

Nesse contexto, Schwartz e Butenko (2014) propuseram a aplicação da teoria refinada em amostra russa, composta por estudantes universitários, conhecidos e familiares daqueles. De maneira dessemelhante de Schwartz et al. (2012), propõem a utilização de comportamentos na mensuração de valores, esclarecendo pesquisas atuais, como indicado por Bardi e Schwartz (2003), investigando as relações entre valores e o comportamento cotidiano. Muitos fatores, além dos valores das pessoas, influenciam seu comportamento cotidiano, mas aqueles autores reforçam que as teorias de valores postulam que estes são uma influência significativa. Argumentam que as pessoas procuram expressar os valores que lhes são caros no comportamento por duas razões principais: a fim de alcançar os objetivos que são importantes para eles e para afirmar os valores que são centrais para a sua autoidentidade (Rokeach, 1973; Schwartz, 2006).

O estudo em destaque aplicou a teoria do valor refinado em um país que apresenta tendências culturais voltadas à ênfase da hierarquia, além do desestímulo à autonomia e ao igualitarismo (Schwartz, 2013), ambiente este que induz os indivíduos a confiarem mais em expectativas sociais para decisões e comportamentos, em comparação aos valores (Bardi \& Schwartz, 2003). Esse contexto possibilita a generalização das relações de valorcomportamento para outras culturas, nas quais os indivíduos tendem a confiar mais nos valores para adoção de novas ações.

A validade discriminante e preditiva da teoria refinada foi alcançada para a amostra russa, além da constatação da ordenação estabelecida pelo contínuo dos valores para quase todos os achados, como também a constatação do gênero como moderador das relações comportamento-valor em cinco dos 19 domínios, determinando a possibilidade de investigações mais aprofundadas neste quesito (Schwartz \& Butenko, 2014). Uma das 
limitações do estudo, apontada pelos próprios autores, foi o uso exclusivo de autoavaliações para medir o comportamento, visto que algumas das associações de valor-comportamento relatadas podem ter ocorrido devido à recordação de experiências pretéritas relevantes.

Ainda na lacuna apontada por Schwartz et al. (2012), acerca da necessidade de aplicação da teoria refinada dos valores em outras culturas não abrangidas pelo estudo, Torres, Schwartz e Nascimento (2016) buscaram examinar se os 19 valores propostos são discriminados por amostras brasileiras e se estes mantêm a configuração estabelecida no contínuo. Ademais, reforçando o fato de que Schwartz et al. (2012) examinaram o poder preditivo dos valores com relação a atitudes e crenças, propuseram a verificação da associação dos valores às variáveis comportamentais.

Os resultados de ambos os estudos realizados na pesquisa de Torres et al. (2016) foram capazes de discriminar os 19 valores em amostras brasileiras, amplificando a validade da teoria de valores refinados e demonstrando sua resistência às mudanças no instrumento de medida. Além disso, o posicionamento no contínuo foi correspondente ao obtido na teoria, em termos gerais, com exceção dos valores de universalismo e benevolência, de maneira semelhante aos achados de Schwartz et al. (2012) e de Schwartz e Butenko (2014), com amostras de diferentes nacionalidades.

Ainda que apontem como limitação da pesquisa o uso exclusivo de auto e heterorrelatos de comportamentos, por conta da possiblidade de utilização de frequência de comportamentos específicos, Torres et al. (2016) avançaram também na observação da relação valor-comportamento, visto que possíveis exageros na mensuração dos efeitos da citada associação provavelmente foram reduzidos ao se utilizarem métodos complementares de relatos próprios e de outrem, em vista de diferentes possibilidades apresentadas por cada um destes. 
Nestes estudos - Schwartz et al. (2012), Schwartz e Butenko (2014), e Torres et al. (2016) - dois tipos de análises, basicamente, fornecem evidência acerca da capacidade de distinção dos 19 valores por parte dos respondentes, e se os instrumentos de mensuração são capazes de captar, de maneira adequada, as distinções que as pessoas fazem: a análise fatorial confirmatória (AFC) e o escalonamento multidimensional (MDS). Outros estudos apresentaram o mesmo formato em culturas diversas (e.g. Mcquilkin, Garðarsdóttir, Thorsteinsson, \& Schwartz, 2016; Schwartz et al., 2016 apud Schwartz, no prelo), como Islândia, Estados Unidos, Itália, Polônia e Rússia, com a constatação do suporte dos fatores latentes distintos para os 19 valores.

Tamir et al. (2016) desenvolveram um estudo focado no alcance de abrangente testagem transcultural de valores baseada em emoções desejadas. Para tanto, participantes de oito países - Estados Unidos, Brasil, China, Alemanha, Gana, Israel, Polônia e Cingapura participaram do estudo, representando sete das diferentes regiões culturais mundiais (Anglo, América Latina, Confúcio, Europa Ocidental, África Subsaariana, Europa Centro-Oriental e Ásia Meridional). Os autores esperavam que quanto mais pessoas endossassem certos valores, mais desejariam emoções que fossem consistentes com eles.

Os autores acreditam também que tais padrões de associações apresentem consistência entre culturas, apesar do fato de que as culturas diferem nos valores que seus membros priorizam (Schwartz, 2006) e nas emoções que desejam (por exemplo, Tsai et al., 2006). Esta expectativa, entretanto, evidencia razões claras, visto que se baseia na consistência da estrutura de valores entre culturas (e.g., Schwartz, 1992; Schwartz et al., 2012) e na suposição de que há provavelmente uma tendência universal para que os indivíduos desejem emoções que promovam a perseguição de seus objetivos pessoais.

Outras pesquisas utilizam a teoria refinada dos valores para predição ou associação com outras variáveis, como benefícios esperados na escolha de um banco principal por 
prefeitos de cidades brasileiras (Martino, 2016), na influência da intenção do indivíduo em sair da organização em que trabalha (Santos, 2016), na hierarquia dos valores de estudantes de ciências contábeis da USP (Bortolatto Júnior, 2014), na análise das motivações para o voluntariado em um hospital público da cidade de São Paulo (Siqueira, 2016), na avaliação dos imigrantes como representando ameaças ou benefícios à sociedade de acolhimento (Tartakovsky \& Walsh, 2016), e satisfação com a vida em grupos sociodemográficos construídos a partir da população russa (Khaptsova \& Schwartz, 2016), ou também na verificação da consistência das emoções desejadas dos indivíduos com seus valores centrais (Tamir et al., 2016).

Desta maneira, a teoria refinada dos valores demonstra-se significativamente útil na compreensão empírica de diversos fenômenos, tanto por seus atributos de adequação teórica e capacidade de ordenação do contínuo em amostras de culturas diversas, quanto pela centralidade dos valores para os indivíduos, com interferências e associações claras com as emoções, atitudes e os comportamentos das pessoas, em suas relações cotidianas com os grupos dos quais faz parte, com os grupos que interage, nas organizações, no trabalho, auxiliando o indivíduo na construção de sua identidade pessoal e social.

Uma vez visitada a literatura sobre valores e, conforme indicado, sua interconexão com as atitudes, segue-se a discussão sobre o conceito de atitudes, com uma breve contextualização histórica e conceituação. $\mathrm{O}$ entendimento mais aprofundado do tema é relevante em vista do posicionamento acerca do medo do crime, como variável tripartite, como a atitude, e podendo ser visualizado como atitude voltada ao crime.

\subsection{Atitudes}

As atitudes constituem um posicionamento valorativo do indivíduo acerca do mundo, de diversificados objetos e situações, enfim, de "qualquer componente do ambiente, 
psicologicamente representado" (Torres \& Carneiro, 2015, p. 95). Referem-se, assim, a um estado interno que pode ser aferido com base em observações de respostas avaliativas positivas ou negativas, favoráveis ou desfavoráveis, aprováveis ou desaprováveis, desejáveis ou indesejáveis, em relação ao objeto atitudinal, voltadas a uma coisa, um lugar, um grupo, um comportamento, objetos tangíveis ou intangíveis (Maio \& Haddock, 2015; Fonseca, Porto, \& Barroso, 2012; Neiva \& Mauro, 2011).

Ao avaliar os objetos - de maneira positiva ou negativa - verifica-se influência na maneira como as pessoas enxergam o mundo, em seus pensamentos e ações, o que potencializa a importância das atitudes. Por conta dessa centralidade na compreensão do pensamento e do próprio comportamento humano, os psicólogos sociais dedicaram, e ainda dedicam, muita atenção ao entendimento de como as atitudes são formadas, de como estas influenciam a rotina dos indivíduos e como mudam ao longo do tempo (Maio \& Haddock, 2015).

\subsubsection{Contextualização histórica e conceituação}

Originária do latim, a palavra atitude une actius (ação) e aptitudo (aptidão), sendo primeiramente utilizada no campo da arte, como termo técnico, servindo para descrever a disposição de uma figura em estátua ou desenho (Neiva \& Mauro, 2011). A história da pesquisa em atitudes remonta aos estudos sobre "atitudes motrizes" de Fere (1888), Langen (1889) e de Munstergerg (1890 apud Solozabal, 1981).

O estudo das atitudes tem uma história extensa dentro da psicologia social, com ambas emergindo na virada do século XX. De fato, Gordon Allport (1935, p. 198), um renomado pesquisador que ajudou a inspirar pesquisas sobre atitudes, observou que "o conceito de atitude é provavelmente o conceito mais distintivo e indispensável na psicologia social americana contemporânea”. Essa opinião também foi compartilhada por especialistas 
fora da psicologia social, como sociólogos e psicólogos comportamentais (e. g. McGuire, 1986). Na década de 1920, um número de indivíduos se interessou em medir propriedades mentais subjetivas como atitudes. Naquela época, tamanha era a importância do trabalho sobre a medição de atitudes que a psicologia social era muitas vezes definida como o estudo das atitudes (McGuire, 1985; Neiva \& Mauro, 2011; Torres \& Carneiro, 2015).

Dois importantes pesquisadores dessa época foram Louis Thurstone e Rensis Likert. Thurstone e Likert desenvolveram várias maneiras de medir as atitudes, principalmente o Método do Intervalo de Aparição Igual (Thurstone, 1928; Thurstone \& Chave, 1929) e a escala de Likert (1932). A pesquisa de Thurstone e Likert foi significativamente influente porque demonstrou que as atitudes podem ser mensuradas de forma quantificável pavimentando o caminho para o desenvolvimento da disciplina. De fato, a capacidade dos cientistas de medir as atitudes foi vista como um enorme avanço, e ainda na atualidade, as escalas de Likert continuam a ser uma ferramenta importante para pesquisadores interessados em avaliar atitudes e opiniões. Além de desenvolver estratégias destinadas a medir as atitudes, a pesquisa inicial também considerou o grau em que as atitudes dos indivíduos influenciam seu comportamento (LaPiere, 1934).

Não é possível negar que o foco da pesquisa em psicologia social é muitas vezes influenciado por eventos do mundo real. Os acontecimentos da Segunda Guerra Mundial levaram psicólogos sociais, como Kurt Lewin, que escapou da Alemanha nazista na década de 1930, e muitos dos progenitores da psicologia social, como Solomon Asch, Leon Festinger e Muzafer Sherif, a estudarem processos como conformidade, poder e dinâmica de grupo (Maio \& Haddock, 2015). Tais pesquisas demonstram relevância direta para o estudo das atitudes e os tipos de questões que as pessoas começaram a abordar, passando o estudo das atitudes a ganhar ímpeto na tentativa de abordar preocupações sociais maiores. 
Nesse sentido, Theodore Adorno e colaboradores (Adorno, Frenkel-Brunswick, Levinson \& Sanford, 1950) buscaram entender os processos que levam os indivíduos a desenvolverem atitudes autoritárias, em particular, as bases psicológicas e sociais das atitudes antissemitas. Para tanto, desenvolveram a escala $\mathrm{F}$ (de fascismo) e sua pesquisa sobre o autoritarismo desempenhou um papel importante na compreensão do desenvolvimento do preconceito contra grupos étnicos minoritários. Várias décadas depois, a pesquisa de Bob Altemeyer (1996) desenvolveu essa linha de investigação, provocando um ressurgimento do interesse pelo conceito de autoritarismo.

A Segunda Guerra Mundial foi relevante também em outros aspectos do desenvolvimento da psicologia social, cabendo destacar a dinâmica da persuasão, evidenciada pelo sucesso das campanhas de propaganda nazista, o que chamou a atenção dos países aliados para a relevância de entender como mobilizar e modificar a opinião pública (McGuire, 1986). Após a guerra, o interesse pela persuasão permaneceu consistente devido ao surgimento da Guerra Fria e à evolução das telecomunicações (como a ampla disponibilidade de televisão). Em consequência, os pesquisadores continuaram a estudar como os indivíduos respondem a mensagens persuasivas.

Esses pesquisadores instigaram a pesquisa científica sobre a mudança de atitude examinando quando e como as atitudes são mais propensas a mudar (Hovland, Janis, \& Kelley, 1953). Como observado por McGuire (1986), a abordagem da escola de Yale (formada por Hovland, Janis e outros) era convergente porque começou com um fenômeno particular - mudança de atitude - que precisava de explicação. Os pesquisadores avaliaram então uma ampla gama de variáveis, a fim de determinar quais são importantes para explicar o fenômeno e, ainda mais relevante, estes estudos abordaram como fatores relacionados às características da fonte da mensagem, ao destinatário da mensagem e à própria mensagem persuasiva determinam a probabilidade de mudança de atitude. Suas descobertas foram 
significativamente influentes em ajudar psicólogos sociais a entender como e quando a persuasão é mais provável de ocorrer (McGuire, 1986).

Neste mesmo período, Leon Festinger e outros colaboradores abordaram outras questões relevantes para a mudança de atitude. Como observado por McGuire (1986), a abordagem de Festinger foi divergente: começou com uma teoria particular e aplicou-a a uma ampla gama de fenômenos atitudinais. Uma teoria que Festinger aplicou foi a Teoria da Dissonância Cognitiva (Festinger, 1957), que se refere a um estado de desequilíbrio entre as crenças, incluindo as crenças que suportam as atitudes de uma pessoa, sugerindo que a realização de crenças inconsistentes produz um sentimento negativo que os indivíduos estão motivados a reduzir. Aplicada às atitudes, a teoria da dissonância cognitiva sugere que uma pessoa com duas atitudes inconsistentes seria motivada a mudar uma dessas atitudes para recuperar um estado de consonância.

Um último desenvolvimento importante durante este período pós-guerra recente foi a verificação das razões pelas quais as pessoas detêm atitudes - o estudo das funções de atitude - abrangendo as necessidades psicológicas servidas por atitudes. Dois grupos de pesquisadores desenvolveram taxonomias de funções de atitude: Smith, Bruner e White (1956) e Katz e outros colaboradores (Katz, 1960; Katz \& Stotland, 1959) postulam que as atitudes podem servir a uma série de funções ou necessidades de um indivíduo. Uma das funções mais relevantes e marcantes é a de avaliação de objetos - a capacidade de atitudes para servir como dispositivos de poupança de energia que tornam os julgamentos mais fáceis e rápidos de executar. As atitudes também podem ajudar as pessoas a expressar seus valores, a identificarem-se com as pessoas de que gostam e a protegerem-nas do feedback negativo.

Os pesquisadores de atitude têm frequentemente notado que as atitudes são baseadas em informações cognitivas, afetivas e comportamentais (Allport, 1935; Bandura, 1977; Oslon \& Maio, 2003). Fishbein (1966) apontava que as atitudes podem ser agrupadas nestas três 
grandes partes; entretanto foi na década de 1980 que a pesquisa sobre esse conteúdo começou a crescer. Esta pesquisa abordou questões como a forma como as pessoas organizam seus pensamentos, sentimentos e experiências passadas sobre um objeto de atitude particular (Haddock \& Maio, 2015).

Nas duas últimas décadas, um dos principais temas sobre atitude tem sido o estudo de sua resistência, sendo que as atitudes fortes foram encontradas para diferir de atitudes fracas em um número de maneiras. Atitudes fortes são mais: (i) persistentes ao longo do tempo, (ii) resistentes à mudança, (iii) susceptíveis de influenciar o processamento da informação, e (iv) susceptíveis de prever o comportamento (Krosnick \& Petty, 1995). A pesquisa sobre a força da atitude também tem desempenhado um papel importante na resposta às questões relacionadas ao grau em que as atitudes são estáveis versus temporárias (Wilson, Lindsey, \& Schooler, 2000).

Como vislumbrado na retrospectiva apresentada, um dos primeiros a definir o conceito de atitude foi Thurstone (1928), para quem esta constitui um afeto pró ou contrário a um determinado objeto psicológico. Allport (1935), por sua vez, visualiza a atitude como um estado mental e neural de prontidão, organizado por meio da experiência, e capaz de exercer uma influência que direciona a resposta dos indivíduos a todas as situações e objetos com os quais se relaciona. $\mathrm{O}$ modelo de três componentes foi sugerido pelo autor, nos seguintes termos:

(i) um componente afetivo (ou avaliativo) que reflete o gostar ou não gostar de um determinado objeto (psicológico) ou situação. Para Thurstone (1928), o conceito de atitude já estava plenamente estabelecido com este componente;

(ii) um componente cognitivo, estabelecido em crenças que as pessoas possuem sobre determinado objeto (psicológico) ou situação; 
(iii) um componente comportamental, capaz de refletir as tendências comportamentais sobre determinado objeto (psicológico) ou situação.

\section{Estímulo}

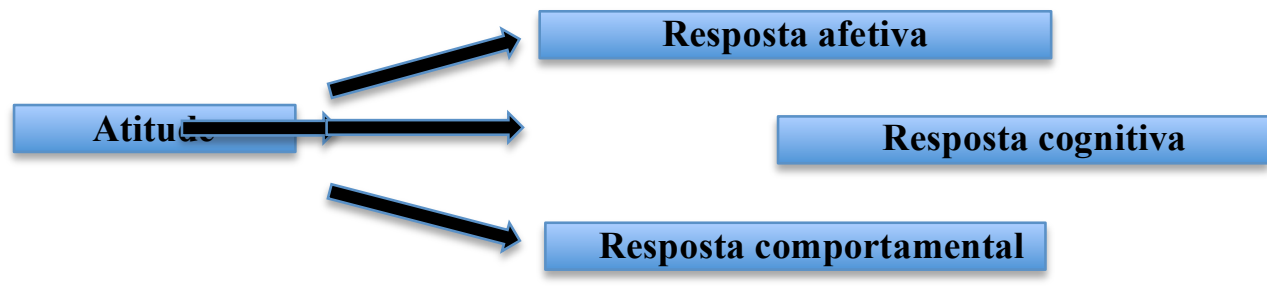

Figura 4. Os componentes da atitude

Fonte: Neiva e Mauro (2011)

Doob (1947) estabelece a atitude como uma resposta implícita e motriz que é considerada socialmente significativa na sociedade do indivíduo. Esta definição afirma, de fato, que do ponto de vista psicológico a atitude é uma resposta implícita com força motriz, de natureza interna, sendo estabelecida como reação a padrões de estímulo, e com a capacidade de modificar o comportamento subsequente do indivíduo. Smith, Bruner e White (1956), por sua vez, visualizavam a atitude com predisposição para experimentar uma classe de objetos de determinadas maneiras, com afeto característico, sendo, consequentemente, motivados a agir de maneira específica.

Fishbein e Ajzen (1975), por conta das inconsistências que podem ocorrer entre os três componentes sugeridos por Allport (1935), sugeriram que estes fossem tratados separadamente, e a atitude seria relacionada apenas ao afeto. Para os autores, a atitude é uma organização duradoura de crenças e cognições em geral, dotada de carga afetiva favorável ou desfavorável e dirigido a um objeto social, predispondo uma ação coerente com as cognições e afetos relativos a esse objeto. Fishbein e Ajzen (1975) entendiam a atitude como afeto, crença como cognição e intenção comportamental como comportamento, trazendo proximidade com o entendimento apresentado décadas antes por Thurstone (1928). 
Segundo alguns autores, existe certo consenso geral de que a atitude representa uma avalição sumária de um objeto psicológico, visualizado em seus atributos como bom ou ruim, nocivo ou positivo, prazeroso ou desagradável, gostável ou não (Eagly \& Chaiken, 1993; Petty, Wegener, \& Fabrigar, 1997; Ajzen \& Fishbein, 2000). É sempre importante salientar, entretanto, que pesquisas recentes sugerem que alguns objetos induzem reações avaliativas, outros sugerem a necessidade dos indivíduos em se engajar em respostas avaliativas, de modo que alguns indivíduos apresentam maior necessidade de avaliar que outros, o que repercute em uma "produção maior de atitudes".

Torres e Carneiro (2015) tratam ainda da Teoria da Expectância, na qual o indivíduo julga, racionalmente, os atributos de determinado objeto. Medidas de atitudes baseadas nesse modelo teórico possibilitam a atribuição de valor numérico ao grau de aprovação do indivíduo a cada atributo do objeto, para posterior multiplicação entre importância e grau de aprovação de cada atributo, decidindo-se em seguida os predominantes.

Como asseveram Pimentel, Torres, e Günther (2011), o modelo tripartido (ou teoria tripartite) e o modelo de valor-expectativa (teoria da ação racional, com foco nas crenças avaliativas) têm conduzido a pesquisa sobre o conteúdo das atitudes. As atitudes podem então ser mensuradas de acordo com esses conceitos, após a definição clara de que tipo de teoria está sendo utilizada e quantos componentes - unicomponente (afeto), bicomponente (afeto e cognição) e tricomponente (afeto, cognição e comportamento) - serão atribuídos ao constructo.

Como já ressaltado em outros pontos do trabalho, a teoria adotada nessa dissertação acerca do medo do crime é a tricomponente ou tripartite, sendo importante, além de estabelecer a revisão teórica acerca dos valores e das atitudes, apresentar também as relações entre atitudes e valores (e comportamentos), corroborando com o papel preditivo dos valores 
humanos individuais sobre as atitudes, particularmente o medo do crime e a atitude frente à arma de fogo, no caso desta dissertação.

\subsection{Atitudes e Valores (e Comportamentos)}

Rokeach (1973), no intuito de clarificar a natureza da relação entre valores e atitudes, utilizou, entre outros mecanismos, as funções das atitudes, que já haviam sido estabelecidas por alguns autores, entre os quais pode-se destacar Katz (1960), o qual apresentou quatro funções atitudinais:

(i) utilitária - maneira para maximizar uma ação, seja ela para maximizar benefícios, seja para minimizar prejuízos;

(ii) defesa do ego - proteger um indivíduo de alguma verdade a seu respeito;

(iii) conhecimento - compreender os fenômenos, integrando-os de forma coerente;

(iv) expressão de valor - expressar de forma positiva seus valores ou autoconceito para a sociedade.

Para Rokeach (1981), atitudes e valores encontram interligação dentro do sistema cognitivo do indivíduo, visto que a atitude é uma "organização de crenças, relativamente duradoura, em torno de um objeto ou situação que predispõe que se responda de alguma forma preferencial” (p. 91). Já o valor é um traço disposicional da pessoa, de maneira idêntica à atitude, mas com características ainda mais basilares e fundamentais, quando comparado à atitude, localizando-se em subjacência a esta, comumente. Rokeach (1981) vislumbra o valor como crença também duradoura, com centralidade ainda maior que a atitude, no que diz respeito aos modos de conduta e estados finais de existência.

De maneira ainda mais didática, o valor enquadra-se como uma entidade abstrata, sem ligação direta a nenhum objeto ou situação específicos, possibilitando que uma pessoa possua milhares de atitudes (visto serem estas dirigidas a cada objeto ou situação), com um número 
de valores mais exíguo, por serem estes transituacionais. Rokeach (1981) salienta que os dois constructos estão interligados dentro do sistema de atitudes e valores de cada indivíduo, sendo uma das funções das atitudes a expressão dos valores deste mesmo indivíduo. Consequência direta do entendimento do autor é o caráter determinante do valor ante a atitude e o comportamento, pois, uma vez internalizado, ele se torna "consciente ou inconscientemente, um padrão ou critério para guiar a ação, para desenvolver e manter as atitudes em relação a objetos e situações relevantes, para julgar moralmente a si e aos outros e para se comparar com os outros" (Rokeach, 1981, p. 132). Segundo Reigh e Adcock (1976), há uma coerência intrapessoal entre valores e atitudes, e as orientações de valor podem ser boas indicadoras de atitudes específicas.

Os valores são crenças hierarquizadas sobre estilos de vida e formas de existência que orientam as atitudes e comportamentos dos indivíduos, consubstanciando-se como elemento central da personalidade, enquanto as atitudes e comportamentos seriam mais periféricos, fazendo com que os valores se estabeleçam como núcleo central do autoconceito e da autoestima (Rokeach, 1973). Enquanto Rokeach enfatiza a relação entre valores, atitudes e comportamento, Williams Jr. (1979) admite a influência causal dos valores no comportamento, eliminando, por outro lado, as atitudes.

Homer e Kahle (1988), ao sugerirem um instrumento com nove valores, extraídos do modelo teórico de Rokeach, tentam resolver a discrepância ao analisarem a relação entre valores, atitudes e comportamento. Seus resultados demonstram que os valores analisados se estruturam em duas dimensões, interna e externa, pertencendo à primeira o autorrespeito, a autorrealização, a diversão e a alegria na vida, a emoção, sentido de realização e relações afetuosas com os outros; já a segunda engloba o sentido de pertencimento, ser respeitado e a segurança. Enquanto os valores internos apresentavam relação com atitudes favoráveis e com comportamento de consumo de comida natural, os externos estavam relacionados com 
atitudes e comportamentos contrários. Os autores posicionam-se, neste desenvolvimento, pela mediação da atitude entre valores e comportamentos (Homer e Kahle, 1988).

Snyder e DeBono (1989) contribuíram, em parte, com evidências acerca da relação entre valores, atitudes e comportamento, ao desenvolverem o traço de personalidade da autovigilância do eu como medida indireta da função das atitudes. Segundo o entendimento dos autores, pessoas com pontuação baixa neste traço, ou seja, aquelas que não se preocupam muito com a impressão que os outros possuem dela, costuma orientar o comportamento baseando-se em seus valores, sentimentos e atitudes, enquanto a pontuação alta em vigilância do eu - pessoas que se preocupam com a aceitação dos outros - costumam adaptar seu comportamento, padronizando-o ao comportamentos dos indivíduos que se encontram nas adjacências. É mais plausível, no entendimento dos autores, que as atitudes dos que apresentam pontuação baixa em autovigilância sejam expressivas de seus valores, enquanto as atitudes das que pontuam alto cumpram uma função de adaptação social, ou mesmo uma função utilitária.

A consistência entre valores e atitudes, particularmente aquela pertinente à existência de moderação das atitudes refletidas pelo traço de personalidade de autovigilância, foi testada por autores como Kristiansen e Zanna (1988) e Mellena e Bassili (1995). No caso destes últimos, foram estudadas as atitudes, favoráveis ou desfavoráveis, voltadas às políticas de cotas de emprego em favor da mulher e de proibição de filmes pornográficos. Os valores de igualdade, mérito, liberdade, religiosidade e respeito pela autoridade foram escolhidos por sua relação direta com essas atitudes. Pessoas que valorizavam mais a igualdade, por exemplo, costumavam ter atitudes de maior tolerância em relação às cotas de empregos favoráveis à mulher e aos filmes pornográficos, enquanto as que valorizavam a autoridade e a religiosidade, tinham atitudes mais favoráveis à proibição de tais filmes. 
Diante das teorias estabelecidas, tanto acerca das atitudes, como acerca das relações entre valores e atitudes, e entre estes e o comportamento dos indivíduos, dois posicionamentos claros podem ser estabelecidos no contexto desta pesquisa: a relação entre valores e atitudes, com predição daqueles em relação a estas, incluindo ainda uma associação clara entre ambos e comportamentos das pessoas (ainda que algumas teorias se preocupem em reforçar a "associação direta" entre valores e comportamento); e o predomínio da utilização da teoria tripartite das atitudes, englobando os componentes afetivo, cognitivo e comportamental, e o interesse constantemente significativo da psicologia social em identificar e entender as associações entre indivíduos e os objetos sociais disponíveis para eles.

Tratando ainda de atitudes, e tendo o medo do crime como plano de fundo, verifica-se relevante trazer à discussão alguns objetos psicológicos importantes para o bem-estar e harmonia social, entre os quais podem ser destacados a mensuração de atitudes frente às drogas pesadas (Gouveia, Pimentel, Medeiros, Gouveia, \& Palmeira, 2007), ao álcool (Gouveia, Pimentel, Leite, Albuquerque, \& Costa, 2009), à maconha (Gouveia, Pimentel, Queiroga, Meira, \& Jesus, 2005), à violência (Anderson, Benjamin, Wood, \& Bonacci, 2006), à polícia (Nascimento, Torres, \& Pimentel, 2011), às armas (Branscombe, Weir, \& Crosby, 1991), entre outros constructos.

Estes constructos fazem parte de questões relacionadas ao crime e, em consequência, ao medo dirigido a ele, tornando-se interessante entender se na relação entre valores e a atitude frente ao crime (trabalhado neste estudo como medo do crime), podem ser aplicadas outra(s) variável(is) atitudinais de objetos específicos que fazem parte do contexto da violência e criminalidade. Este incremento pode trazer benefícios ao entendimento mais apurado das variáveis utilizadas no estudo, como também auxiliar na concepção mais aguçada dos aspectos relacionados às amostras estudadas. 
Uma delas, a atitude frente à arma de fogo, é interessante para o contexto brasileiro em vista de algumas circunstâncias, entre as quais podem ser destacados os altos índices de criminalidade nas cidades brasileiras, com incidência de arma de fogo em diversos delitos (homicídio, latrocínio, roubo, sequestro, entre outros), em que pese a existência de uma legislação restritiva com relação ao acesso - porte e posse - da arma de fogo, sendo este permitido a determinadas pessoas após o cumprimento de diversos requisitos, em dissonância com o verificado em alguns outros países.

\subsection{Atitude Frente à Arma de Fogo}

\subsubsection{Contexto nacional}

A questão das armas de fogo, sua origem, comercialização, circulação, uso e posse vêm recebendo crescente atenção na mídia e na produção intelectual no Brasil, o que faz com que atualmente exista certo número de estudos que tentam quantificar ou qualificar esse fenômeno, mas, ainda assim, as carências na área são enormes. As estatísticas existentes sobre o tema são consideradas incompletas e pouco confiáveis por especialistas das áreas de criminologia, vitimologia e segurança pública. Não há sequer um balanço formal do número de armas existentes no País, temos apenas estimativas extraoficiais (Waiselfisz, 2016).

Os grandes produtores de armas, amparando-se em princípios que são questionados por diversos atores sociais que lidam com a temática, fornecem escassas informações sobre suas transações nacionais ou internacionais. A Pesquisa de Armas Portáteis de $2015^{1}$, em seu anexo 4.1, que detalha a movimentação dos países exportadores de armas leves, indica nas observações que o Brasil não relatou as exportações de foguetes e lançadores de granadas,

\footnotetext{
${ }^{1}$ O Small Arms Survey é um centro pertencente ao Instituto Superior de Estudos Internacionais com sede na Suíça, apoiado por grande número de governos, principalmente da Europa, destinado a gerar informação para subsidiar políticas em matéria de armas leves e violência armada. Resultados disponíveis em: http://www.smallarmssurvey.org/publications/by-type/yearbook/small-arms-survey-2015.html.
} 
armas de fogo militares, revólveres e pistolas, peças e acessórios de revólveres e pistolas ou armas pequenas e munição para 2012.

Waiselfisz (2016) explana que apesar da incipiência do controle na comercialização das armas (em quantidade), a situação da mortalidade que as armas de fogo originam são bem mais confiáveis, por possuir um elevado grau de sistematização e cobertura. Trata-se do Subsistema de Informação sobre Mortalidade do Ministério da Saúde (SIM/MS), atualmente na Secretaria de Vigilância em Saúde (SVS), cujos dados são divulgados anualmente desde 1979. O SIM constitui a fonte básica dos dados trabalhados no levantamento Mapa da Violência 2015: Mortes Matadas por Armas de Fogo.

Por não existiram informações atualizadas sobre as armas de fogo no Brasil, o estudo de Dreyfus e Nascimento (2005) guarda ainda relevância, menos por conta da quantidade de armas que aponta, e mais pela proporção de armas de fogo em mãos da população. Segundo estimativa dos autores, à época existiam um total de mais de 17 milhões de armas no Brasil 17.010.941, para ser mais exato -, e destas (pp. 120-121):

- mais de 15,2 milhões em mãos privadas (15.257.808);

- quase 6,8 milhões legalizadas (6.764.951);

- quase 8,5 milhões irregulares (8.492.857);

- dentre estas, mais de 3,8 milhões em mãos criminosas (3.857.799).

Como as armas irregulares podem facilmente ser repassadas às mãos criminosas, exatamente pela ausência de controle estatal, alguns autores, como Nascimento et al. (2016) estimam essa quantidade em mais de 5,26 milhões de armas nas mãos de criminosos (p. 239). A magnitude do arsenal guarda estreita correspondência com a mortalidade que essas armas originam. Os registros do SIM/MS permitem verificar que, entre 1980 e 2014, morreram perto de 1 milhão de pessoas (967.851), vítimas de disparo de algum tipo de arma de fogo. Nesse período, as vítimas passam de 8.710, no ano de 1980, para 44.861, em 2014, o 
que representa um crescimento de $415,1 \%$. Levando em consideração que a população do país cresceu em torno de $65 \%$, apresenta-se um saldo líquido do crescimento da mortalidade por armas de fogo, já descontado o aumento populacional, que impressiona pela magnitude.

Essa eclosão das mortes foi alavancada, de forma quase exclusiva, pelos homicídios por arma de fogo, que cresceram 592,8\%, setuplicando em 2014, o volume de 1980; enquanto os suicídios com armas de fogo aumentaram 44,8\%, menor que o crescimento populacional, e as mortes acidentais caíram 3,6\%. Por último, as mortes por arma de fogo de causalidade indeterminada, isto é, sem especificação (não se sabe se foi suicídio, homicídio ou acidente), tiveram uma queda moderada de 20,4\%. Como vemos pelos números, os homicídios representaram, ao longo do período analisado, $85,8 \%$ do total de mortes por armas de fogo. Mas uma grande parte da massa de mortes por armas de fogo de causalidade indeterminada deveria ser creditada na fileira dos homicídios. Por esse motivo, é possível afirmar que praticamente $95 \%$ da utilização letal das armas de fogo no Brasil tem como finalidade o extermínio intencional do próximo (Waiselfisz, 2016).

Centrando o foco nos homicídios, observa-se que a evolução da letalidade das armas de fogo não foi homogênea ao longo do tempo. Entre 1980 e 2003, o crescimento deste tipo de homicídio foi sistemático e constante, com um ritmo significativamente acelerado: $8,1 \%$ ao ano. A partir do pico de 36,1 mil mortes, alcançado em 2003, os números, num primeiro momento, caíram para aproximadamente 34 mil e, depois de 2008, ficaram oscilando em torno das 36 mil mortes anuais, para acelerar novamente a partir de 2012. Assim, no último ano com dados disponíveis, apresenta-se um volume de 42,3 mil homicídios por arma de fogo. O Estatuto e a Campanha do Desarmamento, iniciados em 2004, constituem-se em um dos fatores determinantes na explicação dessa quebra de ritmo. 


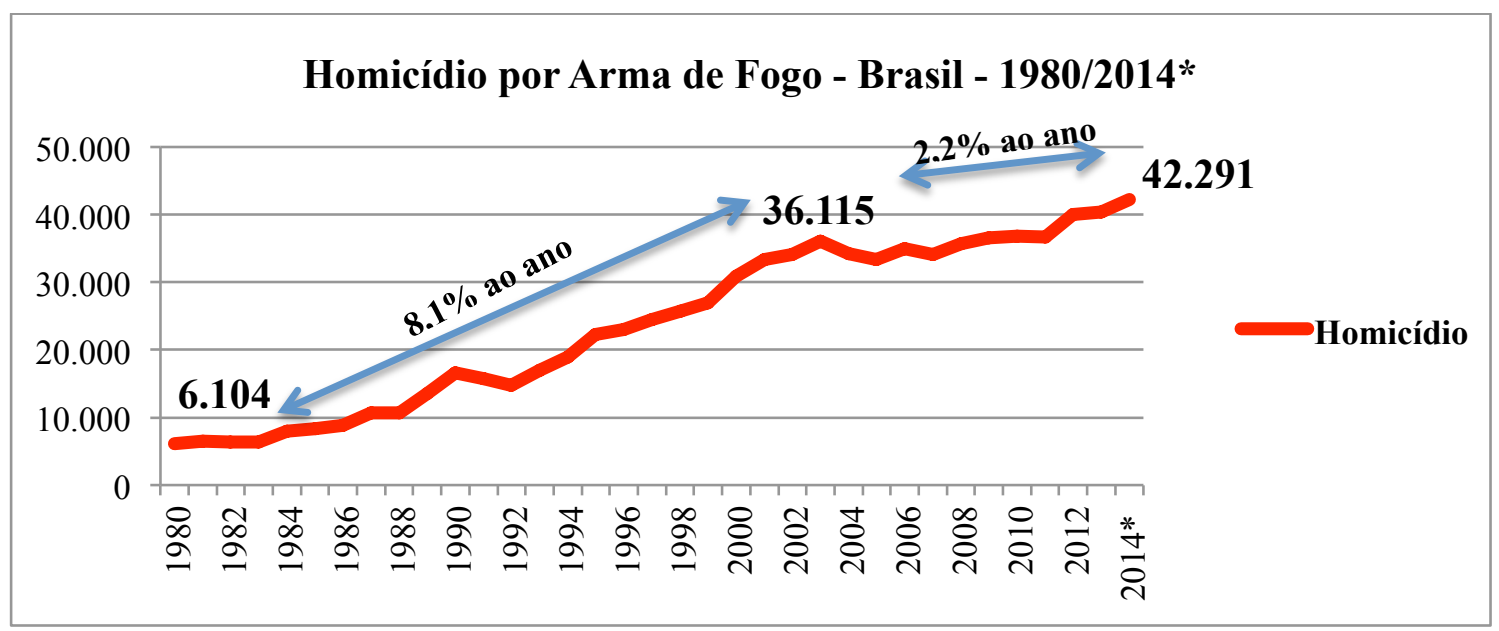

Figura 5. Vítimas de Homicídio por Arma de Fogo. Brasil (1980/2014*)

Fonte: Waiselfisz (2016)

*: dados preliminares

Esses dados indicam que as políticas de desarmamento, se conseguiram sofrear a tendência do crescimento acelerado da mortalidade por armas de fogo imperante no país, não foram constantes ao longo do tempo - sofreram interrupções, abandonos e retomadas nem foram complementadas com outras estratégias e reformas necessárias para reverter o processo e fazer os números regredirem. Mas resultado evidente, pelos dados, que o ímpeto anterior da escalada homicida foi drasticamente enfraquecido. Apesar de ser frequentemente utilizada, tanto a favor quanto contra o Estatuto do Desarmamento, a leitura que utiliza o número de vítimas de homicídios por arma de fogo para sopesar as políticas de controle de armas de fogo, instauradas em 2004, não é totalmente correta, já que desconsidera que nesse período a população do país também cresceu (Waiselfisz, 2016).

\subsubsection{Contexto do Distrito Federal}

Analisar os dados do Mapa da Violência 2016 (Homicídios por Arma de Fogo no Brasil), por Unidade Federativa, proporciona a observação da existência de grande diversidade de situações que caracterizam a evolução dos homicídios por armas de fogo no país. Efetivamente, o crescimento médio de $23,7 \%$ no número vítimas de homicídios desta 
natureza na década 2004-2014, que equivale a um aumento de 11,1\% nas taxas de homicídio, é resultante de um conjunto de realidades locais e regionais fortemente diferenciadas. Numa breve observação da Tabela 5, é possível analisar o desenvolvimento dos números de homicídio ao longo dos anos.

Tabela 5

Homicídios por Arma de Fogo. UF e Região. 2004/2014*

\begin{tabular}{|c|c|c|c|c|c|c|c|}
\hline UF/REGIÃO & 2004 & 2007 & 2010 & 2013 & 2014* & $\Delta \% 1$ & $\Delta \% 2$ \\
\hline Acre & 49 & 51 & 63 & 97 & 116 & 136,7 & 19,6 \\
\hline Amapá & 74 & 60 & 103 & 99 & 142 & 91,9 & 43,4 \\
\hline Amazonas & 227 & 415 & 635 & 692 & 756 & 233,0 & 9,2 \\
\hline Pará & 969 & 1.385 & 2.502 & 2.254 & 2.319 & 139,3 & 2,9 \\
\hline Rondônia & 334 & 321 & 351 & 300 & 388 & 16,2 & 29,3 \\
\hline Roraima & 31 & 28 & 29 & 69 & 47 & 51,6 & $-31,9$ \\
\hline Tocantins & 100 & 88 & 131 & 140 & 164 & 64,0 & 17,1 \\
\hline Norte & 1.784 & 2.348 & 3.814 & 3.651 & 3.932 & 120,4 & 7,7 \\
\hline Alagoas & 754 & 1.552 & 1.721 & 1.872 & 1.818 & 141,1 & $-2,9$ \\
\hline Bahia & 1.590 & 2.700 & 4.439 & 4.289 & 4.441 & 179,3 & 3,5 \\
\hline Ceará & 916 & 1.224 & 2.057 & 3.652 & 3.792 & 314,0 & 3,8 \\
\hline Maranhão & 355 & 602 & 827 & 1.382 & 1.658 & 367,0 & 20,0 \\
\hline Paraíba & 472 & 656 & 1.208 & 1.251 & 1.246 & 164 & $-0,4$ \\
\hline Pernambuco & 3.344 & 3.706 & 2.649 & 2.301 & 2.522 & $-24,6$ & 9,6 \\
\hline Piauí & 131 & 184 & 207 & 373 & 454 & 246,6 & 21,7 \\
\hline Rio Grande do Norte & 237 & 438 & 611 & 1.153 & 1.292 & 445,1 & 12,1 \\
\hline Sergipe & 301 & 348 & 452 & 723 & 896 & 197,7 & 23,9 \\
\hline Nordeste & 8.100 & 11.410 & 14.171 & 16.996 & 18.119 & 123,7 & 6,6 \\
\hline Espírito Santo & 1.188 & 1.363 & 1.359 & 1.289 & 1.290 & 8,6 & 0,1 \\
\hline Minas Gerais & 3.255 & 2.983 & 2.456 & 3.455 & 3.338 & 2,5 & $-3,4$ \\
\hline Rio de Janeiro & 6.193 & 5.102 & 4.111 & 3.562 & 3.582 & $-42,2$ & 0,6 \\
\hline São Paulo & 7.611 & 4.150 & 3.469 & 3.408 & 3.524 & $-53,7$ & 3,4 \\
\hline Sudeste & 18.247 & 13.598 & 11.395 & 11.714 & 11.734 & $-35,7$ & 0,2 \\
\hline Paraná & 1.912 & 2.285 & 2.630 & 2.042 & 2.073 & 8,4 & 1,5 \\
\hline Rio Grande do Sul & 1.432 & 1.661 & 1.496 & 1.711 & 2.052 & 43,3 & 19,9 \\
\hline Santa Catarina & 377 & 377 & 483 & 439 & 493 & 30,8 & 12,3 \\
\hline Sul & 3.721 & 4.323 & 4.609 & 4.192 & 4.618 & 24,1 & 10,2 \\
\hline Distrito Federal & 506 & 516 & 576 & 656 & 705 & 39,3 & 7,5 \\
\hline Goiás & 988 & 1.009 & 1.317 & 2.096 & 1.985 & 100,9 & $-5,3$ \\
\hline Mato Grosso & 454 & 542 & 566 & 750 & 845 & 86,1 & 12,7 \\
\hline Mato Grosso do Sul & 387 & 401 & 344 & 314 & 353 & $-8,8$ & 12,4 \\
\hline Centro-Oeste & 2.335 & 2.468 & 2.803 & 3.816 & 3.888 & 66,5 & 1,9 \\
\hline Brasil & 34.187 & 34.147 & 36.792 & 40.369 & 42.291 & 23,7 & 4,8 \\
\hline
\end{tabular}

Fonte: Adaptado de Waiselfisz (2016)

Notas: $\Delta \% 1=$ Crescimento $\%$ 2004/2014; $* \Delta \% 2=$ Crescimento $\%$ 2013/2014; $* 2014$-Dados Preliminares. 
Como verificado, o Distrito Federal (DF) vem demonstrando um crescimento percentual significativo ao longo período compreendido entre os anos de 2004 a 2014, com $39,3 \%$ de aumento no número de homicídios por arma de fogo. Olhando por um outro panorama, que estabelece comparação com as demais unidades da federação, o DF ocupa a $18^{a}$ posição entre os 27 entes federados, quanto ao crescimento percentual dos homicídios desta natureza ( $\Delta \% 1$ da Tabela 5$)$, o que pode, em uma primeira visão, estabelecer um contexto favorável para os números relacionados ao homicídio. Ademais, se comparado ao crescimento dos estados integrantes da região centro-oeste, o aumento percentual do DF foi menor (39,3\% contra 66,5\%), visto que os estados de Goiás e Mato Grosso apresentaram crescimentos significativamente maiores no mesmo período.

De outro modo, numa análise um pouco mais profunda, observa-se que os números do DF estão, em verdade, num contexto desfavorável quanto ao tópico em destaque. De maneira mais clara, se comparado aos demais entes federados, o Distrito Federal ocupa a $15^{\text {a }}$ posição entre as unidades que mais apresentaram crescimento percentual do número de homicídios por arma de fogo entre os anos de 2013 e 2014 ( $\Delta \% 2$ da Tabela 5), com 7,5\% de aumento. A comparação deste percentual com o índice da Região Centro-Oeste é negativa $(1,9 \%$ de crescimento para a região), sendo também desfavorável quando comparado ao percentual nacional $(4,8 \%)$. Tratando do percentual nacional, ainda que o DF tenha se estabelecido em uma colocação que aparenta resultados positivos com relação ao crescimento de homicídios entre 2004 e 2014, reforça-se que o DF apresentou crescimento percentual superior ao nacional $(39,3 \%$ contra $23,7 \%)$, o que significa que outros estados obtiveram resultados muito melhores - casos de São Paulo, Rio de Janeiro, Pernambuco e Mato Grosso do Sul -, com decréscimo percentual na quantidade do objeto relatado.

$\mathrm{Na}$ busca pelo entendimento acurado dos homicídios por arma de fogo, é interessante utilizar outro parâmetro de mensuração além das quantidades de incidência do evento. A taxa 
de homicídios por número de habitantes (100 mil é o parâmetro adotado pela Organização das Nações Unidas, como reforça Young, 1996) é um parâmetro de exploração vantajoso, na medida em que compara o crescimento do número de homicídios por arma de fogo em determinada localidade com o avanço populacional. A Tabela 6 apresenta os dados relativos a estas taxas de homicídio por habitantes, por unidade federativa e região, contemplando os anos de 2000 a 2014.

Tabela 6

Taxas de homicídio (por 100 mil habitantes) por arma de fogo. UF e Região. 2000/2014*

\begin{tabular}{|c|c|c|c|c|c|c|c|c|c|c|c|c|}
\hline \multirow{2}{*}{ UF } & \multicolumn{2}{|c|}{2000} & \multicolumn{2}{|c|}{2005} & \multicolumn{2}{|c|}{2009} & \multicolumn{2}{|c|}{2013} & \multicolumn{2}{|c|}{$2014 *$} & \multirow{2}{*}{$\Delta \% 1$} & \multirow{2}{*}{$\Delta \% 2$} \\
\hline & Taxa & Pos. & Taxa & Pos. & Taxa & Pos. & Taxa & Pos. & Taxa & Pos. & & \\
\hline Rio de Janeiro & 47,0 & $1^{\mathrm{o}}$ & 38,9 & $2^{o}$ & 25,0 & $8^{\circ}$ & 21,7 & $13^{\circ}$ & 21,5 & $15^{\circ}$ & $-54,3 \%$ & $-0,9 \%$ \\
\hline Pernambuco & 46,6 & $2^{\circ}$ & 41,7 & $1^{o}$ & 35,4 & $3^{\circ}$ & 24,9 & $10^{\circ}$ & 27,5 & $10^{\circ}$ & $-41,0 \%$ & $10,4 \%$ \\
\hline Espírito Santo & 33,3 & $3^{\circ}$ & 34,9 & $3^{\circ}$ & 44,4 & $2^{o}$ & 33,5 & $4^{\circ}$ & 35,1 & $5^{\circ}$ & $5,4 \%$ & $4,8 \%$ \\
\hline Mato Grosso & 29,8 & $4^{\circ}$ & 17,4 & $8^{\circ}$ & 19,1 & $14^{\circ}$ & 23,5 & $11^{\circ}$ & 26,2 & $11^{\circ}$ & $-12,1 \%$ & $11,5 \%$ \\
\hline $\begin{array}{l}\text { Distrito } \\
\text { Federal }\end{array}$ & 28,8 & $5^{\circ}$ & 19,4 & $7^{\circ}$ & 25,5 & $7^{\circ}$ & 23,4 & $12^{\circ}$ & 25,6 & $12^{\circ}$ & $-11,1 \%$ & $9,4 \%$ \\
\hline São Paulo & 28,7 & $6^{\mathrm{o}}$ & 14,3 & $16^{\circ}$ & 9,3 & $23^{\circ}$ & 7,8 & $26^{\circ}$ & 8,2 & $26^{\circ}$ & $-71,4 \%$ & $5,1 \%$ \\
\hline $\begin{array}{l}\text { Mato Grosso } \\
\text { do Sul }\end{array}$ & 23,9 & $7^{\circ}$ & 15,2 & $13^{\circ}$ & 18,2 & $15^{\circ}$ & 12,1 & $23^{\circ}$ & 13,6 & $23^{\circ}$ & $-43,1 \%$ & $12,4 \%$ \\
\hline Rondônia & 22,0 & $8^{\circ}$ & 23,9 & $5^{\circ}$ & 23,5 & $10^{\circ}$ & 17,3 & $17^{\circ}$ & 23,7 & $14^{\circ}$ & $7,7 \%$ & $37,0 \%$ \\
\hline Alagoas & 17,5 & $9^{\circ}$ & 30,1 & $4^{o}$ & 49,4 & $1^{\mathrm{o}}$ & 56,6 & $1^{\mathrm{o}}$ & 56,1 & $1^{\mathrm{o}}$ & $220,6 \%$ & $-0,9 \%$ \\
\hline Sergipe & 17,2 & $10^{\circ}$ & 16,2 & $11^{\circ}$ & 22,3 & $11^{\circ}$ & 32,8 & $5^{\circ}$ & 41,2 & $3^{\circ}$ & $139,5 \%$ & $25,6 \%$ \\
\hline $\begin{array}{l}\text { Rio Grande do } \\
\text { Sul }\end{array}$ & 16,3 & $11^{\circ}$ & 13,6 & $17^{\circ}$ & 15,1 & $18^{\circ}$ & 15,3 & $19^{\circ}$ & 18,7 & $19^{\circ}$ & $14,7 \%$ & $22,2 \%$ \\
\hline Roraima & 16,0 & $12^{\circ}$ & 7,2 & $23^{\circ}$ & 6,4 & $26^{\circ}$ & 14,0 & $20^{\circ}$ & 9,5 & $25^{\circ}$ & $-40,6 \%$ & $-32,1 \%$ \\
\hline Goiás & 15,6 & $13^{\circ}$ & 16,7 & $10^{\circ}$ & 21,3 & $12^{\circ}$ & 32,5 & $6^{\mathrm{o}}$ & 31,2 & $7^{\circ}$ & $100,0 \%$ & $-4,0 \%$ \\
\hline Paraná & 13,6 & $14^{\circ}$ & 19,8 & $6^{\mathrm{o}}$ & 25,0 & $9^{\circ}$ & 18,5 & $15^{\circ}$ & 19,2 & $18^{\circ}$ & $41,2 \%$ & $3,8 \%$ \\
\hline Bahia & 11,7 & $15^{\circ}$ & 14,6 & $15^{\circ}$ & 29,8 & $4^{\circ}$ & 28,5 & $8^{\circ}$ & 30,7 & $8^{\circ}$ & $162,4 \%$ & $7,7 \%$ \\
\hline Paraíba & 11,5 & $16^{\circ}$ & 15,1 & $14^{\circ}$ & 27,0 & $6^{\circ}$ & 31,9 & $7^{\circ}$ & 31,9 & $6^{\circ}$ & $177,4 \%$ & $0,0 \%$ \\
\hline Tocantins & 10,6 & $17^{\circ}$ & 6,0 & $25^{\circ}$ & 9,9 & $22^{\circ}$ & 9,4 & $25^{\circ}$ & 11,2 & $24^{\circ}$ & $5,7 \%$ & $19,1 \%$ \\
\hline $\begin{array}{l}\text { Rio Grande do } \\
\text { Norte }\end{array}$ & 9,8 & $18^{\circ}$ & 8,9 & $20^{\circ}$ & 19,8 & $13^{\circ}$ & 34,1 & $3^{\circ}$ & 38,9 & $4^{\circ}$ & $296,9 \%$ & $14,1 \%$ \\
\hline Ceará & 9,4 & $19^{\circ}$ & 12,5 & $18^{\circ}$ & 17,7 & $16^{\circ}$ & 41,5 & $2^{\circ}$ & 42,9 & $2^{\circ}$ & $356,4 \%$ & $3,4 \%$ \\
\hline Amazonas & 9,4 & $20^{\circ}$ & 8,2 & $21^{\circ}$ & 16,9 & $17^{\circ}$ & 18,1 & $16^{\circ}$ & 20,2 & $16^{\circ}$ & $114,9 \%$ & $11,6 \%$ \\
\hline Minas Gerais & 8,9 & $21^{\mathrm{o}}$ & 16,1 & $12^{\circ}$ & 13,0 & $19^{\circ}$ & 16,7 & $18^{\circ}$ & 16,4 & $20^{\circ}$ & $84,3 \%$ & $-1,8 \%$ \\
\hline Acre & 8,8 & $22^{\circ}$ & 5,4 & $26^{\circ}$ & 8,8 & $24^{\circ}$ & 12,4 & $22^{\circ}$ & 14,6 & $21^{\mathrm{o}}$ & $65,9 \%$ & $17,7 \%$ \\
\hline Amapá & 8,6 & $23^{\circ}$ & 9,3 & $19^{\circ}$ & 11,0 & $21^{\circ}$ & 13,4 & $21^{\circ}$ & 19,3 & $17^{\circ}$ & $124,4 \%$ & $44,0 \%$ \\
\hline Pará & 8,5 & $24^{\circ}$ & 17,1 & $9^{\circ}$ & 27,4 & $5^{\circ}$ & 28,2 & $9^{\circ}$ & 28,5 & $9^{\circ}$ & $235,3 \%$ & $1,1 \%$ \\
\hline Santa Catarina & 5,9 & $25^{\circ}$ & 6,7 & $24^{\circ}$ & 8,4 & $25^{\circ}$ & 6,6 & $27^{\circ}$ & 7,5 & $27^{\circ}$ & $27,1 \%$ & $13,6 \%$ \\
\hline Piauí & 4,7 & $26^{\circ}$ & 5,0 & $27^{\circ}$ & 5,9 & $27^{\circ}$ & 11,7 & $24^{\circ}$ & 14,0 & $22^{\circ}$ & $197,9 \%$ & $19,7 \%$ \\
\hline Maranhão & 3,6 & $27^{\circ}$ & 8,0 & $22^{\circ}$ & 12,3 & $20^{\circ}$ & 20,3 & $14^{\circ}$ & 23,9 & $13^{\circ}$ & $563,9 \%$ & $17,7 \%$ \\
\hline
\end{tabular}




\begin{tabular}{|c|c|c|c|c|c|c|c|}
\hline BRASIL & 20,7 & 18,1 & 19,3 & 20 & 21,2 & $2,4 \%$ & $6,0 \%$ \\
\hline
\end{tabular}

Notas: $\Delta \% 1=$ Crescimento\% 2004/2014; $* \Delta \% 2$ = Crescimento\% 2013/2014; *2014-Dados Preliminares

A exemplo da Tabela 5, a Tabela 6 preliminarmente oferece um diagnóstico benigno para o DF, em comparação com os demais entes da federação, visto que ocorreu uma melhora em sua ordenação ao longo do tempo: de $5^{\circ}$ em 2000, para $7^{\circ}$ em 2005 e 2009, estabelecendose em $12^{\circ}$ em 2013 e 2014. Salienta-se que aumentar a colocação neste ranking em números absolutos - ou seja de $1^{\circ}$ para $3^{\circ}$, de $2^{\circ}$ para $5^{\circ}$, por exemplo - é desejável, visto que as primeiras colocações são ocupados pelos entes com maiores taxas. Além disso, o percentual de progresso da taxa de homicídios foi negativo para o DF no período de 2000 a 2014 ($11,1 \%$ no $\Delta \% 1$ ), o que demonstra que a população cresceu mais no cotejo com a quantidade de homicídios por arma de fogo, tanto que neste índice o DF atingiu a $21^{\text {a }}$ posição.

Como afirmado anteriormente, faz-se necessário verificar com maior minudência as informações prestadas por Waiselfisz (2016). Em específico, a evolução da taxa de homicídios por habitantes no DF entre os anos de 2013 e 2014 o enquadra na $15^{\text {a }}$ posição (com $9,4 \%$ ), maior que a média nacional para o período $(6,0 \%)$ e pior que alguns estados que mantiveram idêntico valor no período ou alcançaram índices negativos, exemplo de Roraima, Goiás, Minas Gerais, Rio de Janeiro, Alagoas e Paraíba. Além disso, a taxa alcançada pelo DF no ano de 2014 (25,6 homicídios por arma de fogo para cada 100 mil habitantes) é substancialmente desfavorável em referência a Santa Catarina (7,5 homicídios/100 mil), São Paulo (8,2 homicídios/100 mil) e Roraima (9,5 homicídios/100 mil), apenas a título de modelo.

Depois de uma considerável série temporal em que a proporção de homicídios cometidos com armas de fogo mantém-se ao redor de 70\% (Langeani \& Pollachi, 2016) já é consenso entre pesquisadores e gestores o impacto da circulação de armas na dinâmica da violência no Brasil. Ainda assim, há muitos estados em que o controle e a retirada de armas 
ilegais de circulação não são objetos de uma política focalizada, ou seja, acontece circunstancialmente em abordagens policiais ou atendimentos de ocorrências policiais. Em recente pesquisa sobre as armas apreendidas no Sudeste, foi corroborada a informação de que a maioria das armas apreendidas relacionadas a crimes são de fabricação nacional, com algo em torno de $61 \%$ (Langeani \& Pollachi, 2016).

Em manifesto recentemente publicado por pesquisadores de instituições públicas e privadas de ensino e pesquisa no Brasil e no exterior ${ }^{2}$, e assinado por 57 destes, expôs-se um posicionamento contrário à revogação do Estatuto do Desarmamento brasileiro, por conta das "evidências científicas disponíveis acerca da efetividade do Estatuto do Desarmamento como um instrumento para salvar vidas” (p. 1). Tais circunstâncias demonstram evidências de que, ao menos para o contexto brasileiro, as armas de fogo apontam ligação direta com o crime, e consequentemente com o medo do crime, fazendo com que a mensuração da atitude frente à arma de fogo seja verificada como relevante para o desenvolvimento do presente estudo.

\subsection{Aplicação Empírica}

Por já ter ocorrido a oportunidade de detalhamento de atitudes neste trabalho, parte-se para a relevância do entendimento de objetos psicológicos intrínsecos ao bem-estar e à harmonia social, como a mensuração de atitudes frente às drogas pesadas (Gouveia, Pimentel, Medeiros, Gouveia, \& Palmeira, 2007), ao álcool (Gouveia, Pimentel, Leite, Albuquerque, \& Costa, 2009), à maconha (Gouveia, Pimentel, Queiroga, Meira, \& Jesus, 2005), à violência (Anderson, Benjamin, Wood, \& Bonacci, 2006), à polícia (Nascimento et al., 2011), às armas (Branscombe et al., 1991), entre outros constructos.

As atitudes frente à arma de fogo expõem uma lacuna científica severa, como explicam Nascimento et al. (2016). Segundo os autores, após a realização de buscas em bases

\footnotetext{
${ }^{2}$ Manifesto de especialistas disponível em: http://migre.me/v2PAg. Acesso em: 28 out. 2016.
} 
de dados, como a Apa PsycNET da American Psychological Association (APA), tanto para atitudes frente às armas de fogo como para atitudes frente às armas, não foram encontrados resultados relevantes, com exceção da Escala de Atitudes Frente à Arma de Fogo de Branscombe et al. (1991). Os autores investigaram também informações junto ao Scielo Brazil a ao PePSIC, sem achados de interesse.

Na contramão deste panorama, Shapiro, Dorman, Burkey, Welker, e Clough (1997) elaboraram uma medida de atitudes de jovens frente às armas e à violência, encontrando quatro fatores principais, quais sejam: Resposta Agressiva à Vergonha, Conforto com Agressão, Entusiasmo e Poder/Segurança. Em um estudo posterior, Shapiro, Dorman, Welker e Clough (1998) observaram que os meninos apresentaram maiores níveis de atitudes frente à arma de fogo e violência comparados às meninas. Além disso, afroamericanos também alcançaram médias mais altas que os caucasianos, demonstrando que há exposição à arma de fogo relacionada a maiores índices atitudinais dirigidos à arma de fogo e violência.

Pesquisas estadunidenses anteriores sobre armas, com certa similitude, enfocaram as consequências da exposição a armas no comportamento subsequente, com resultados ligados particularmente ao comportamento mais agressivo dos indivíduos. Berkowitz e LePage (1967) argumentaram que, como as armas são uma sugestão agressiva, sua presença encoraja o comportamento agressivo em pessoas que já estão com raiva. Em sua pesquisa, os sujeitos que foram provocados administraram mais e mais fortes choques ao seu atormentador quando as armas estavam presentes do que quando estavam ausentes. Leyens e Parke (1975), correlatamente, também relataram que indivíduos insultados que foram expostos a imagens contendo armas selecionaram níveis de choque mais intensos do que aqueles expostos a imagens mais neutras. $\mathrm{O}$ aumento da agressividade após a exposição a imagens de armas de fogo tem sido observado em ambos os indivíduos que estavam anteriormente irritados, bem 
como aqueles que não tinham experimentado provocação anterior (Caprara, Renzi, Amolini, D’Imperio, \& Travaglia, 1984).

Outros autores buscaram verificar associações entre atitudes frentes às armas e outros constructos e/ou comportamentos, como o consumo de álcool e impulsividade. Encontrou-se relação entre atitudes positivas frente às armas e o uso de álcool entre os homens, como também entre as atitudes e a impulsividade e o comportamento agressivo, tanto em homens quanto em mulheres. Dowler (2002), por seu turno, identificou que as notícias da TV são a principal fonte para notícias sobre crime. Por meio de regressão logística, o autor verificou que os telespectadores regulares do crime são mais prováveis de apresentarem atitudes negativas ao controle de armas e acreditam que as armas podem prevenir o crime.

Branscombe et al. (1991) enxergaram necessidade para criar uma medida voltada às atitudes frente às armas de fogo, principalmente porque as crenças e os sentimentos integrantes destas atitudes podem ser considerados moderadores de comportamentos sociais diversos. Em sua teoria, Branscombe et al. (1991) propõem três dimensões para o constructo: (i) Direitos, que consubstancia a posse de armas como um direito fundamental americano; (ii) Proteção, em que a posse de arma volta-se à defesa dos indivíduos em relação à vitimização criminal; e (iii) Crime, que trabalha com a ligação entre armas de fogo e crime, particularmente no sentido de que o acesso a aquelas possibilita um aumento das taxas deste.

Os achados de Branscombe et al. (1991) externaram efeitos de gênero nos três fatores e na pontuação total, com um posicionamento mais consolidado dos homens de que a arma é um direito, em comparação com as mulheres. Além disso, os homens enxergam de maneira mais preponderante a arma como fator de proteção e vão de encontro ao entendimento de que as armas podem causar ou potencializar o crime. Os autores constataram também correlações positivas dos três fatores da escala com o orgulho americano, percepção como fãs de esportes, falta de confiança nos outros, autoestima e otimismo. Por outro lado, verificaram 
correlações negativas com orientação política, percepção de que os outros são altruístas, independência de grupos, feminismo, medo, depressão e independência pessoal. O instrumento de mensuração do constructo foi aplicado no Brasil, por Nascimento et al. (2016), assunto que será tratado no capítulo seguinte. 


\section{Capítulo 3}

\section{Método}

Este capítulo propõe-se a descrever os procedimentos metodológicos empregados para alcançar os objetivos propostos pelo estudo. Conforme observam Demo (1983) e Giroux e Tremblay (2004), o método explicita o modo de operacionalização, o locus e o focus da pesquisa, descrevendo, neste sentido, como as variáveis foram definidas, mensuradas, a forma de seleção da amostra e os procedimentos empregados para a análise dos dados (Seltizz, Wrightsman \& Cook, 1987).

\subsection{Escolhas Metodológicas de Investigação}

A pesquisa científica baseia-se em escolhas metodológicas relacionadas ao campo e às variáveis relacionadas. Neste palmilhar, este tópico apresentará a escolha dos atores, qual seja, duas amostras de residentes da Região Administrativa IX do Distrito Federal Ceilândia - escolhida para o desenvolvimento do presente estudo, como também os procedimentos de coleta de dados.

\subsubsection{Lócus da pesquisa}

A Companhia de Planejamento do DF - Codeplan - por meio da Pesquisa Distrital por Amostra de Domicílios do Distrito Federal (PDAD/DF) estimou a população urbana do Distrito Federal, em julho de 2013, em 2.786.684 habitantes, enquanto em 2011 era de 2.556.149, e a projeção populacional para o ano de 2016 é de 2.947 .787 , conforme a Tabela 7. Ademais, na Tabela 7 também constam as populações das Regiões Administrativas do DF (RAs) e o percentual da participação de cada uma delas no total da população do DF para os anos de 2011, 2013 e 2016. 
Tabela 7

População das Regiões Administrativas do DF e Participação Percentual destas. 2011/2013/2016

\begin{tabular}{|c|c|c|c|c|c|c|c|}
\hline $\begin{array}{c}\mathrm{Nr} \text { da } \\
\mathrm{RA}\end{array}$ & $\begin{array}{l}\text { Distrito Federal e } \\
\text { Regiões } \\
\text { Administrativas }\end{array}$ & $\begin{array}{c}\text { Populaçã } \\
\text { o Total } \\
2011 \\
\end{array}$ & $\begin{array}{c}\text { Participaçã } \\
\text { o no Total } \\
\text { do DF }\end{array}$ & $\begin{array}{c}\text { Populaçã } \\
\text { o Total } \\
2013 \\
\end{array}$ & $\begin{array}{c}\text { Participaçã } \\
\text { o no Total } \\
\text { do DF }\end{array}$ & $\begin{array}{c}\text { Populaçã } \\
\text { o Total } \\
2016 \\
\end{array}$ & $\begin{array}{c}\text { Participaçã } \\
\text { o no Total } \\
\text { do DF } \\
\end{array}$ \\
\hline 1 & Plano Piloto & 209.926 & $8,21 \%$ & 216.489 & $7,77 \%$ & 220.393 & $7,41 \%$ \\
\hline 2 & Gama & 127.475 & $4,99 \%$ & 134.958 & $4,84 \%$ & 141.911 & $4,77 \%$ \\
\hline 3 & Taguatinga & 197.783 & $7,74 \%$ & 212.863 & $7,64 \%$ & 222.598 & $7,48 \%$ \\
\hline 4 & Brazlândia & 49.418 & $1,93 \%$ & 51.121 & $1,83 \%$ & 52.287 & $1,76 \%$ \\
\hline 5 & Sobradinho & 59.024 & $2,31 \%$ & 63.715 & $2,29 \%$ & 68.551 & $2,30 \%$ \\
\hline 6 & Planaltina & 161.812 & $6,33 \%$ & 185.375 & $6,65 \%$ & 189.412 & $6,37 \%$ \\
\hline 7 & Paranoá & 42.427 & $1,66 \%$ & 46.233 & $1,66 \%$ & 48.020 & $1,61 \%$ \\
\hline 8 & $\begin{array}{l}\text { Núcleo } \\
\text { Bandeirante }\end{array}$ & 22.569 & $0,88 \%$ & 23.714 & $0,85 \%$ & 25.072 & $0,84 \%$ \\
\hline 9 & Ceilândia & 404.287 & $15,82 \%$ & 451.872 & $16,22 \%$ & 489.351 & $16,45 \%$ \\
\hline 10 & Guará & 107.817 & $4,22 \%$ & 119.923 & $4,30 \%$ & 132.685 & $4,46 \%$ \\
\hline 11 & Cruzeiro & 31.230 & $1,22 \%$ & 32.182 & $1,15 \%$ & 33.539 & $1,13 \%$ \\
\hline 12 & Samambaia & 201.871 & $7,90 \%$ & 228.356 & $8,19 \%$ & 254.439 & $8,55 \%$ \\
\hline 13 & Santa Maria & 119.444 & $4,67 \%$ & 122.721 & $4,40 \%$ & 125.123 & $4,21 \%$ \\
\hline 14 & São Sebastião & 77.793 & $3,04 \%$ & 98.908 & $3,55 \%$ & 100.161 & $3,37 \%$ \\
\hline 15 & Recanto das Emas & 124.755 & $4,88 \%$ & 138.997 & $4,99 \%$ & 145.304 & $4,88 \%$ \\
\hline 16 & Lago Sul & 29.677 & $1,16 \%$ & 30.629 & $1,10 \%$ & 29.346 & $0,99 \%$ \\
\hline 17 & Riacho Fundo & 35.268 & $1,38 \%$ & 37.606 & $1,35 \%$ & 40.098 & $1,35 \%$ \\
\hline 18 & Lago Norte & 33.526 & $1,31 \%$ & 34.182 & $1,23 \%$ & 37.455 & $1,26 \%$ \\
\hline 19 & Candangolândia & 15.953 & $0,62 \%$ & 16.886 & $0,61 \%$ & 16.848 & $0,57 \%$ \\
\hline 20 & Águas Claras & 109.935 & $4,30 \%$ & 118.864 & $4,27 \%$ & 148.940 & $5,01 \%$ \\
\hline 21 & Riacho Fundo II & 37.051 & $1,45 \%$ & 39.424 & $1,41 \%$ & 51.709 & $1,74 \%$ \\
\hline 22 & $\begin{array}{l}\text { Sudoeste/Octogona } \\
1\end{array}$ & 51.565 & $2,02 \%$ & 52.273 & $1,88 \%$ & 53.262 & $1,79 \%$ \\
\hline 23 & Varjão & 9.021 & $0,35 \%$ & 9.292 & $0,33 \%$ & 9.215 & $0,31 \%$ \\
\hline 24 & Park Way & 19.648 & $0,77 \%$ & 19.727 & $0,71 \%$ & 19.824 & $0,67 \%$ \\
\hline 25 & SCIA - Estrutural & 32.148 & $1,26 \%$ & 35.094 & $1,26 \%$ & 39.015 & $1,31 \%$ \\
\hline 26 & Sobradinho II & 94.279 & $3,69 \%$ & 97.466 & $3,50 \%$ & 100.755 & $3,39 \%$ \\
\hline 27 & Jardim Botânico & 23.856 & $0,93 \%$ & 25.302 & $0,91 \%$ & 27.364 & $0,92 \%$ \\
\hline 28 & Itapoã & 56.360 & $2,20 \%$ & 59.694 & $2,14 \%$ & 68.587 & $2,31 \%$ \\
\hline 29 & SIA & 2.448 & $0,10 \%$ & 1.997 & $0,07 \%$ & 1.988 & $0,07 \%$ \\
\hline 30 & Vicente Pires & 67.783 & $2,65 \%$ & 72.415 & $2,60 \%$ & 72.789 & $2,45 \%$ \\
\hline \multirow[t]{2}{*}{31} & Fercal & $\ldots$ & & 8.408 & $0,30 \%$ & 8.746 & $0,29 \%$ \\
\hline & Distrito Federal & 2.556 .149 & & 2.786 .684 & & 2.974.787 & \\
\hline
\end{tabular}

Fonte: Adaptado de Codeplan (2015)

Consoante observação da Tabela 7, chama a atenção a participação da RA IX, Ceilândia, no percentual total do DF. Assim, verifica-se que de 2011 a 2016 a população da localidade passou de 404.287 habitantes para 489.351 habitantes, mantendo um percentual significativo de participação no total da população do DF, passando de $15,82 \%$ do total da 
população em 2011 para 16,22\%, sendo a RA com maior participação populacional, bem à frente das demais. Tal contexto, por si só, já seria suficiente para a escolha da Ceilândia como locus da pesquisa que se apresenta, em vista dos seus números. Para uma ideia mais apurada deste panorama, a segunda RA com maior participação - Samambaia, com 254.439 habitantes - possui apenas 52\% da população da Ceilândia, segundo dados da Codeplan (2015).

Adiciona-se a isto alguns outros dados de interesse, apresentados na Tabela 8, que complementam o entendimento da escolha da população da citada RA para desenvolvimento da pesquisa.

Tabela 8

População das Regiões Administrativas vitima de violência. 2013.

\begin{tabular}{|c|c|c|c|c|c|}
\hline $\begin{array}{c}\text { Regiões } \\
\text { Administrativas }\end{array}$ & $\begin{array}{c}\text { População Total } \\
2013\end{array}$ & $\begin{array}{c}\text { Já sofreram } \\
\text { violência }\end{array}$ & $\begin{array}{c}\text { Violência / } \\
\text { população }(\%)^{\mathrm{a}}\end{array}$ & $\begin{array}{l}\text { Sofreram violência } \\
\text { na cidade em que } \\
\text { residem }\end{array}$ & $\begin{array}{c}\text { Violência } \\
\text { onde reside } \\
\text { população } \\
(\%)^{\mathrm{b}}\end{array}$ \\
\hline Recanto das Emas & 138.997 & 18.427 & $13,26 \%$ & 12.624 & $9,08 \%$ \\
\hline Ceilândia & 451.872 & $\mathbf{5 7 . 0 4 7}$ & $12,62 \%$ & 40.962 & $9,06 \%$ \\
\hline Samambaia & 228.356 & 25.149 & $11,01 \%$ & 15.373 & $6,73 \%$ \\
\hline Santa Maria & 122.721 & 11.457 & $9,34 \%$ & 6.785 & $5,53 \%$ \\
\hline Paranoá & 46.233 & 4.170 & $9,02 \%$ & 2.407 & $5,21 \%$ \\
\hline Riacho Fundo II & 39.424 & 3.326 & $8,44 \%$ & 2.047 & $5,19 \%$ \\
\hline Candangolândia & 16.886 & 1.154 & $6,83 \%$ & 875 & $5,18 \%$ \\
\hline Núcleo Bandeirante & 23.714 & 1.799 & $7,59 \%$ & 1.141 & $4,81 \%$ \\
\hline Taguatinga & 212.863 & 14.917 & $7,01 \%$ & 10.128 & $4,76 \%$ \\
\hline Gama & 134.958 & 8.798 & $6,52 \%$ & 5.650 & $4,19 \%$ \\
\hline Planaltina & 185.375 & 13.646 & $7,36 \%$ & 6.998 & $3,78 \%$ \\
\hline São Sebastião & 98.908 & 4.712 & $4,76 \%$ & 3.216 & $3,25 \%$ \\
\hline Itapoã & 59.694 & 3.070 & $5,14 \%$ & 1.412 & $2,37 \%$ \\
\hline Plano Piloto & 216.489 & 7.610 & $3,52 \%$ & 4.884 & $2,26 \%$ \\
\hline Cruzeiro & 32.182 & 976 & $3,03 \%$ & 616 & $1,91 \%$ \\
\hline Guará & 119.923 & 4.273 & $3,56 \%$ & 2.227 & $1,86 \%$ \\
\hline Riacho Fundo & 37.606 & 1.804 & $4,80 \%$ & 690 & $1,83 \%$ \\
\hline Vicente Pires & 72.415 & 2.576 & $3,56 \%$ & 1.299 & $1,79 \%$ \\
\hline Lago Norte & 34.182 & 1.336 & $3,91 \%$ & 558 & $1,63 \%$ \\
\hline Lago Sul & 30.629 & 1.231 & $4,02 \%$ & 498 & $1,63 \%$ \\
\hline SCIA - Estrutural & 35.094 & 1.226 & $3,49 \%$ & 534 & $1,52 \%$ \\
\hline Sobradinho & 63.715 & 1.617 & $2,54 \%$ & 960 & $1,51 \%$ \\
\hline Águas Claras & 118.864 & 2.988 & $2,51 \%$ & 1.752 & $1,47 \%$ \\
\hline Park Way & 19.727 & 944 & $4,79 \%$ & 254 & $1,29 \%$ \\
\hline Brazlândia & 51.121 & 1.838 & $3,60 \%$ & 635 & $1,24 \%$ \\
\hline Sudoeste/Octogonal & 52.273 & 835 & $1,60 \%$ & 638 & $1,22 \%$ \\
\hline SIA & 1.997 & 32 & $1,60 \%$ & 10 & $0,50 \%$ \\
\hline Jardim Botânico & 25.302 & 674 & $2,66 \%$ & 120 & $0,47 \%$ \\
\hline
\end{tabular}




\begin{tabular}{lccccc} 
Varjão & 9.292 & 421 & $4,53 \%$ & 39 & $0,42 \%$ \\
Sobradinho II & 97.466 & 1.481 & $1,52 \%$ & 326 & $0,33 \%$ \\
Fercal & 8.408 & 119 & $1,42 \%$ & 26 & $0,31 \%$ \\
\hline Distrito Federal & $\mathbf{2 . 7 8 6 . 6 8 4}$ & $\mathbf{1 9 9 . 6 4 9}$ & $\mathbf{7 , 1 6 \%}$ & $\mathbf{1 2 5 . 6 8 3}$ & $\mathbf{4 , 5 1 \%}$ \\
\hline
\end{tabular}

(Tabela 8)

Fonte: Adaptado de Codeplan (2013)

Notas: ${ }^{\text {a } V i o l e ̂ n c i a / P o p u l a c ̧ a ̃ o ~(\%) ~ r e f e r e-s e ~ a o ~ p e r c e n t u a l ~ r e s u l t a n t e ~ d a ~ d i v i s a ̃ o ~ d a s ~ c o l u n a s ~ " s o f r e r a m ~}$ violência" e população.

b Violência onde reside/População (\%) refere-se ao percentual resultante da divisão das colunas "sofreram violência na cidade em que residem" e população.

A pesquisa distrital, realizada pela Codeplan (2013), dispôs números acerca da violência sofrida pelos habitantes das regiões administrativas, momento em que se nota a preponderância da Ceilândia, ocupante da $2^{\mathrm{a}}$ posição acerca da taxa de pessoas que relataram casos de violência em comparação à população da localidade. A violência trazida à discussão neste tópico diz respeito a diversos crimes, desde o roubo, o furto, a agressão física, o abuso sexual, o sequestro relâmpago, até a residência roubada e a tentativa de homicídio. Esta posição de destaque - negativa, diga-se de passagem - solidifica-se ainda mais ao verificar-se o percentual de pessoas que sofreram violência na cidade em que residem, visto que a Ceilândia enquadra-se novamente na $2^{\mathrm{a}}$ posição.

Neste panorama, a Região Administrativa de Ceilândia mostra-se um lócus de pesquisa adequado, em razão tanto do tamanho de sua população como das características relacionadas à vitimização e violência demonstrada pelos seus residentes, em estudos realizados pelas instituições oficiais de estatísticas lidadoras do tema.

\subsubsection{Participantes da pesquisa}

Tais argumentos possibilitam a arguição requerida para o estabelecimento da população a ser pesquisada. Entretanto, torna-se fundamental aproveitar a oportunidade para praticar alguns posicionamentos interessantes trazidos por Henrich, Heine e Norenzayan (2010) acerca das limitações que as pesquisas em psicologia social vêm apresentando, particularmente nas amostras utilizadas. A preocupação destes enquadra-se no que eles 
alcunharam de WEIRD (em referência aos países ocidentais, com altos níveis de escolaridade na população, industrializados, ricos e democráticos, em especial, os Estados Unidos da América).

Reforça este posicionamento a análise realizada nas principais revistas e em seis subdisciplinas de psicologia de 2003 a 2007, a qual revelou que 68\% dos indivíduos vinham dos Estados Unidos e 96\% dos sujeitos eram de países industrializados ocidentais, especificamente da América do Norte e da Europa, como Austrália e Israel (Arnett, 2008). A composição dessas amostras parece refletir em grande parte o país de residência dos autores, pois $73 \%$ dos primeiros autores estavam em universidades americanas e $99 \%$ eram universidades de países ocidentais. Isto significa que $96 \%$ das amostras psicológicas provêm de países com apenas $12 \%$ da população mundial.

Mesmo no Ocidente, no entanto, o método de amostragem típico para estudos experimentais está longe de ser representativo. No Journal of Personality and Social Psychology da American Psychological Association (APA), o primeiro periódico em psicologia social - a subdisciplina da psicologia que deveria (indiscutivelmente) ser a mais atenta às questões sobre os antecedentes dos sujeitos $-67 \%$ das amostras americanas (e $80 \%$ das amostras de outros países) eram compostas apenas por alunos de graduação em cursos de psicologia (Arnett, 2008). Em outras palavras, um estudante de graduação americano, selecionado aleatoriamente, é mais de 4000 vezes mais propenso a ser um participante de pesquisa do que uma pessoa selecionada aleatoriamente de fora do Ocidente. Além disso, esta tendência para se basear em amostras de graduação não diminuiu com o tempo (Peterson, 2001; Wintre, North, \& Sugar, 2001). Tais estudos são, portanto, amostragem de uma subpopulação bastante limitada dentro de cada país (ver Rozin, 2001). Henrich et al. (2010) complementam que os americanos com alto nível de educação escolar (tiveram a 
oportunidade de estudar muitos anos) diferem de outros americanos em muitos aspectos importantes.

Isto posto, sugere-se a dissecação dos dados obtidos acerca da formação superior completa (que abarca inclusive a formação posterior à superior, como especialização, mestrado e doutorado), a partir do percentual de habitantes com curso superior completo em cada região administrativa, apresentado na Tabela 9.

Tabela 9

Percentual de Habitantes com Curso Superior Completo

\begin{tabular}{|c|c|c|c|c|c|c|}
\hline Região Administrativa & $\begin{array}{l}\text { Superior } \\
\text { Completo }\end{array}$ & Pos. & $\begin{array}{c}\text { Superior } \\
\text { Completo }\end{array}$ & Pos. & $\begin{array}{l}\text { Superior } \\
\text { Completo }\end{array}$ & Pos. \\
\hline Lago Sul & $59,71 \%$ & $2^{\circ}$ & $63,35 \%$ & $2^{\circ}$ & $68,59 \%$ & $1^{\circ}$ \\
\hline Sudoeste/Octogonal & $59,60 \%$ & $3^{\circ}$ & $66,10 \%$ & $1^{\mathrm{o}}$ & $64,50 \%$ & $2^{o}$ \\
\hline Plano Piloto & $49,71 \%$ & $4^{\circ}$ & $53,34 \%$ & $5^{\circ}$ & $56,55 \%$ & $3^{\circ}$ \\
\hline Lago Norte & $63,23 \%$ & $1^{\mathrm{o}}$ & $57,96 \%$ & $3^{\circ}$ & $55,99 \%$ & $4^{\mathrm{o}}$ \\
\hline Park Way & $42,25 \%$ & $6^{\circ}$ & $54,05 \%$ & $4^{\circ}$ & $50,18 \%$ & $5^{\circ}$ \\
\hline Jardim Botânico & $47,27 \%$ & $5^{\circ}$ & $49,14 \%$ & $6^{\circ}$ & $49,14 \%$ & $6^{\mathrm{o}}$ \\
\hline Águas Claras & $30,50 \%$ & $7^{\circ}$ & $37,86 \%$ & $7^{\circ}$ & $40,99 \%$ & $7^{\circ}$ \\
\hline Cruzeiro & $28,80 \%$ & $8^{\circ}$ & $31,66 \%$ & $8^{\circ}$ & $32,72 \%$ & $8^{\circ}$ \\
\hline Guará & $23,69 \%$ & $9^{\circ}$ & $28,79 \%$ & $9^{\circ}$ & $30,39 \%$ & $9^{\circ}$ \\
\hline Vicente Pires & $18,89 \%$ & $11^{\circ}$ & $23,54 \%$ & $10^{\circ}$ & $29,25 \%$ & $10^{\mathrm{o}}$ \\
\hline SIA & $10,95 \%$ & $15^{\circ}$ & $17,02 \%$ & $14^{\mathrm{o}}$ & $23,73 \%$ & $11^{\mathrm{o}}$ \\
\hline Taguatinga & $17,11 \%$ & $13^{\circ}$ & $18,24 \%$ & $12^{\mathrm{o}}$ & $22,11 \%$ & $12^{\circ}$ \\
\hline Núcleo Bandeirante & $18,91 \%$ & $10^{\circ}$ & $18,01 \%$ & $13^{\circ}$ & $20,60 \%$ & $13^{\circ}$ \\
\hline Sobradinho II & $15,50 \%$ & $14^{\circ}$ & $15,90 \%$ & $15^{\circ}$ & $18,66 \%$ & $14^{\mathrm{o}}$ \\
\hline Sobradinho & $18,70 \%$ & $12^{\circ}$ & $18,87 \%$ & $11^{\circ}$ & $18,31 \%$ & $15^{\circ}$ \\
\hline Riacho Fundo & $9,09 \%$ & $17^{\circ}$ & $13,62 \%$ & $16^{\circ}$ & $16,00 \%$ & $16^{\mathrm{o}}$ \\
\hline Candangolândia & $9,08 \%$ & $18^{\circ}$ & $10,88 \%$ & $17^{\circ}$ & $15,90 \%$ & $17^{\circ}$ \\
\hline Gama & $10,31 \%$ & $16^{\circ}$ & $9,84 \%$ & $18^{\circ}$ & $12,66 \%$ & $18^{\circ}$ \\
\hline São Sebastião & $2,44 \%$ & $26^{\circ}$ & $6,00 \%$ & $20^{\circ}$ & $8,00 \%$ & $19^{\circ}$ \\
\hline Brazlândia & $4,74 \%$ & $19^{\circ}$ & $6,54 \%$ & $19^{\circ}$ & $7,27 \%$ & $20^{\circ}$ \\
\hline Samambaia & $3,99 \%$ & $23^{\circ}$ & $5,65 \%$ & $21^{\circ}$ & $6,67 \%$ & $21^{\mathrm{o}}$ \\
\hline Riacho Fundo II & $3,94 \%$ & $24^{\circ}$ & $5,24 \%$ & $23^{\circ}$ & $6,45 \%$ & $22^{\circ}$ \\
\hline Planaltina & $4,39 \%$ & $22^{\circ}$ & $5,11 \%$ & $24^{\mathrm{o}}$ & $6,41 \%$ & $23^{\circ}$ \\
\hline Ceilândia & $4,56 \%$ & $20^{\circ}$ & $4,70 \%$ & $26^{\circ}$ & $6,02 \%$ & $24^{\circ}$ \\
\hline Recanto das Emas & $2,15 \%$ & $27^{\circ}$ & $3,06 \%$ & $28^{\circ}$ & $5,52 \%$ & $25^{\circ}$ \\
\hline Santa Maria & $4,45 \%$ & $21^{\circ}$ & $5,37 \%$ & $22^{\circ}$ & $5,11 \%$ & $26^{\circ}$ \\
\hline Paranoá & $3,28 \%$ & $25^{\circ}$ & $3,93 \%$ & $27^{\circ}$ & $4,87 \%$ & $27^{\circ}$ \\
\hline Itapoã & $0,52 \%$ & $30^{\circ}$ & $4,72 \%$ & $25^{\circ}$ & $4,71 \%$ & $28^{\circ}$ \\
\hline Varjão & $1,78 \%$ & $28^{\circ}$ & $1,48 \%$ & $29^{\circ}$ & $2,56 \%$ & $29^{\circ}$ \\
\hline
\end{tabular}




\begin{tabular}{lcccccc} 
Fercal & - & - & $1,10 \%$ & $30^{\circ}$ & $2,03 \%$ & $30^{\circ}$ \\
SCIA - Estrutural & $0,55 \%$ & $29^{\circ}$ & $0,51 \%$ & $31^{\circ}$ & $1,53 \%$ & $31^{\circ}$ \\
\hline Distrito Federal & $15,87 \%$ & - & $17,27 \%$ & - & $19,00 \%$ & - \\
\hline
\end{tabular}

Fonte: Adaptado de Codeplan (2015)

Como se pode verificar, a Ceilândia apresenta um dos piores índices quanto à formação superior dos seus habitantes, no âmbito do DF. A ordenação da região possibilita constatar, inclusive, que a situação vem piorando nos últimos anos em comparação com as outras RAs, o que demonstra claramente o que o Henrich et al. (2010) defenderam em seus achados: a utilização exclusiva da população universitária desta localidade seria um limitador de difícil transposição, com relação aos resultados e abrangência da pesquisa.

Diante disso, propõe-se o estabelecimento de duas amostras nesta pesquisa, ambas necessariamente residentes na região administrativa de Ceilândia serão formadas da seguinte maneira: uma delas, da população em geral, com a aplicação de questionário impresso em toda a extensão da localidade; a outra amostra, de estudantes universitários, em instituição de ensino particular sediada na Ceilândia, e que possui mais de $85 \%$ dos seus estudantes - de cursos diversos, como administração, direito, gestão pública, gestão de recursos humanos, psicologia, gastronomia, engenharias, entre outros - como residentes da região enfocada.

Será realizado um estudo comparativo entre as amostras na tentativa de aprofundar o reconhecimento de semelhanças e diferenças entre estas, como também de verificar aspectos intrínsecos próprios desta localidade. Hair, Black, Babin, Anderson e Tathan (2009) argumentam que é necessário balizar a amostra pela quantidade de variáveis independentes presentes no modelo da regressão multiplicado por 10. Assim, devido ao fato de a escala de medo do crime possuir 19 constructos, 190 respondentes para cada uma das populações estudadas satisfaria a amostra mínima para o estudo.

\subsection{Instrumentos de Pesquisa (Escalas de cada variável)}




\subsubsection{Escala de Valores Humanos Individuais Refinada (PVQ-R)}

No intuito de verificar a associação entre os valores e o medo do crime - capacidade de predição - foi utilizada a escala de Valores Humanos PVQ-R (Portrait Values Questionnaire Revised) estabelecida por Schwartz et al. (2012) e validada para amostras brasileiras por Torres et al., (2016). Schwartz et al., (2012) utilizam a escala tipo Likert em sua amplitude original, variando em 6 pontos, que questiona o respondente sobre quanto aquela pessoa se parece com ele desde "Não se parece nada comigo" até "Se parece muito comigo".

Schwartz et al. (2012) listam os 19 tipos motivacionais de sua escala, com evidências de validade nos Estados Unidos da América, conforme descritos na tabela a seguir com suas siglas no modelo; a escala foi validada por Torres et al. (2016), no Brasil, com seus respectivos alfas de Cronbach descritos na Tabela 10.

Tabela 10

Tipos motivacionais dos Valores Humanos no Brasil

\begin{tabular}{|c|c|c|c|}
\hline Sigla & Tipo motivacional & Valor Humano & Alfa de Cronbach \\
\hline SDT & Autodireção de Pensamento & \multirow{4}{*}{ Abertura à Mudança } & \multirow{4}{*}{0,89} \\
\hline DAS & Autodireção de Ação & & \\
\hline ST & Estimulação & & \\
\hline $\mathrm{HE}$ & Hedonismo & & \\
\hline $\mathrm{AC}$ & Realização & \multirow{4}{*}{ Autopromoção } & \multirow{4}{*}{0,88} \\
\hline POD & Poder de Domínio & & \\
\hline POR & Poder sobre Recursos & & \\
\hline FAC & Face & & \\
\hline SES & Segurança Social & \multirow{6}{*}{ Conservação } & \multirow{6}{*}{0,85} \\
\hline SEP & Segurança Pessoal & & \\
\hline TR & Tradição & & \\
\hline COR & Conformidade com Regras & & \\
\hline $\mathrm{COI}$ & Conformidade Interpessoal & & \\
\hline HUM & Humildade & & \\
\hline $\mathrm{BEC}$ & Conformidade com Regras & \multirow{3}{*}{ Autotranscendência } & \multirow{3}{*}{0,83} \\
\hline BED & Benevolência Cuidado & & \\
\hline UNC & Universalismo Compromisso & & \\
\hline
\end{tabular}




\begin{tabular}{ll|l|}
\hline UNN & Universalismo Natureza & \\
\hline UNT & Universalismo Tolerância &
\end{tabular}

Fonte: Schwartz et al. (2012) e Torres et al. (2016)

\subsubsection{Escala de Atitude Frente à Arma de Fogo (EAFAF)}

Elaborada por Branscombe et al. (1991), a escala foi testada inicialmente com 59 itens e três dimensões - Direito, Proteção e Crime - e após análise dos componentes principais, com rotação varimax, os autores chegaram a 17 itens (com cargas fatoriais superiores a 0,50 ), obtendo a escala coeficientes de precisão satisfatórios, sendo $\alpha=0,89$ para o total da escala (com o fator Crime invertido), $\alpha=0,89$ para o fator Direitos, $\alpha=0,78$ para o fator Proteção e $\alpha=0,83$ para o fator Crime. Para adequação do estudo ao contexto brasileiro, foram realizados dois estudos por Nascimento et al. (2016) para conhecer evidências da validade fatorial e consistência interna do instrumento, realizando análises exploratórias para checar o número e adequação dos fatores a serem extraídos. Para tanto, foi realizado um estudo com 200 policiais militares do DF, escolhidos não-aleatoriamente, sendo a maioria de homens, solteiros e ocupantes do cargo de soldado.

Após a Análise Fatorial Exploratória realizada e em similaridade ao modelo de Brancombe et al. (1991), foi estabelecida uma estrutura trifatorial, sendo o primeiro fator formado pelos itens concernentes ao fator Direito focado na avaliação se a posse de armas deve ser considerado um direito básico do brasileiro; o segundo pelos itens do fator Crime, uma justificação prática para a proibição de armas entre os membros do público em geral, já que as armas estimulam ou causam crimes que não ocorreria de outra forma, e o terceiro pelos itens do fator Proteção, focando uma justificação para a posse de armas como uma proteção da vitimização criminal. Juntos os fatores foram responsáveis por explicar $48,21 \%$ da variância explicada.

Foram calculadas estatísticas descritivas (medidas de tendência central e dispersão), além da realização do teste do poder discriminativo dos itens. Foi realizada análise de 
componentes principais (PCA), com a utilização prévia do KMO - que precisa ser ao menos de 0,60 - e do Teste de Esfericidade de Bartlett. Para definição do número de fatores, foram empregadas técnicas mais robustas, optando-se pela análise paralela (PA) de Horn (1965) e pelo método Hull, adaptado para o uso na Análise Fatorial Exploratória, em lugar de empregar apenas o critério de Kaiser, que superestima o valor dos fatores. Avaliou-se a adequação de ser realizada uma análise fatorial, tendo sido os resultados favoráveis: $\mathrm{KMO}=$ 0,81 e Teste de Esfericidade de Bartlett, $\chi^{2}(136)=992,22, p<0,000$. A correlação entre os itens dos três fatores obtidos foi positiva entre os itens dos três fatores.

No segundo estudo, foi aplicado o mesmo instrumento para estudantes universitários (220, no total), com 17 itens, mesmo um dos itens não obtendo os parâmetros necessários, e na visão de Nascimento et al. (2016) justifica-se a utilização destes itens na AFC, por conta da possibilidade de não confirmação da estrutura fatorial obtida pela AFE. Os indicadores de ajuste do modelo, apesar de não terem sido extraordinários, foram bastante promissores: $\chi^{2}$ $(116)=237,08, \mathrm{p}<0,000 ; \chi^{2} / \mathrm{g} .1 .=2,04 ; \mathrm{GFI}=0,88 ; \mathrm{CFI}=0,91 ; \mathrm{RMSEA}=0,069 \quad(\mathrm{IC} 90 \%=0,56-$ $0,82)$ e SRMR $=0,062$. No que se refere aos indicadores de consistência interna, os alfa de Cronbach observados foram superiores ao valor recomendado na literatura $(0,70$; Pasquali, 2003). Entretanto, ao se analisarem os índices de consistência interna, nos dois estudos, é possível verificar que quando considerada a amostra de policiais o valor de $\alpha(0,65)$ para o fator "Crime" foi menor do que o recomendado na literatura - para direito foi 0,81 e proteção 0,76 .

\subsubsection{Escala de Medo do Crime}

Para a confecção prévia dos itens pertencentes à Escala de Medo do Crime (EMC) realizou-se uma verificação pormenorizada em instrumentos válidos (Baumer, 1985; Clarke \& Lewis, 1982; Lee, 1982; Norris \& Kaniasty, 1994; Warr \& Stafford, 1983), revisões sobre 
o tema (Hale, 1996; Farrall et al., 1997), além de literatura voltada a constructos correlatos (tais como incivilidades, percepção de risco e vulnerabilidade), tudo no intuito de possibilitar a definição operacional do constructo e sua representação em instrumento a ser validado.

Foram elaborados, inicialmente, 20 itens com base em documentos válidos, revisões sobre o tema, além de literatura voltada a constructos correlatos (Hirtenlehner \& Farrall, 2013; Rader, Cossman \& Porter, 2012). Tais itens foram submetidos à avaliação de juízes (de conteúdo e semântica), estando estruturados antes da avaliação destes: 6 itens para o atributo comportamental, 7 itens para o atributo cognitivo e 7 itens para o atributo afetivo. Segundo Pasquali (2010) é mais apropriada que a análise dos juízes seja referenciada como análise de constructo, visto que estes julgam a adequação da representação dos atributos latentes deste constructo. Entretanto, o próprio autor destaca que é muito comum denominar esta fase de análise de conteúdo, expressão utilizada nesta pesquisa.

Os atributos integrantes do constructo serviram para possibilitar sua mensuração, e no caso do objeto em estudo, serve também para classificá-lo como atitude voltada ao crime. Assim, pretende-se estudar o medo do crime a partir de uma verificação atitudinal, o que possibilita o surgimento de três atributos principais:

(i) Afetivo (Emocional): volta-se à expressão de emoções em face de determinados contextos ou eventos criminais;

(ii) Cognitivo (Julgamento): diz respeito à capacidade dos indivíduos de avaliarem a segurança em relação à possibilidade de serem vítimas de determinado crime em determinados contextos; e

(iii) Comportamental: trata de informações acerca de evitação e de como os indivíduos previnem a si mesmos de tornarem-se vítimas de crimes.

Em consequência, a definição operacional para o medo do crime volta-se aos componentes que são realizados ou deixados de realizar pela percepção de que algo 
(relacionado ao crime) pode vir a acontecer consigo ou com alguém próximo à pessoa. $\mathrm{O}$ instrumento utiliza escala do tipo Likert com cinco opções de resposta distintas a depender da indagação aplicada, indo de (1) nunca/definitivamente esse fato não vai acontecer/totalmente incapaz/nada/totalmente improvável/totalmente inseguro a (5) sempre/todos os dias/certamente esse fato vai acontecer/totalmente capaz/totalmente/totalmente provável/totalmente seguro, existindo também itens que apresentam nove possibilidades de resposta (1) nada até (9) totalmente. Ademais, foram estabelecidos itens de múltipla escolha, com 10 a 13 letras cada, com opções de respostas distintas (sim ou não; pouco importante, muito importante ou não se aplica) para cada letra, disponibilizando ainda resposta aberta, caso o respondente julgasse necessário. A aplicação deve ser feita individualmente e a duração média para a realização é de 20 minutos, embora não haja limite de tempo para resposta.

A análise de conteúdo e semântica do instrumento foi realizada com estudantes de pós-graduação e egressos de diferentes áreas e departamentos da Universidade de Brasília, alguns deles integrantes da Polícia Militar do Distrito Federal (PMDF). Esta análise objetivou verificar a compreensão dos itens por membros da população-alvo, tendo os juízes realizado avaliação individual ou em grupos de no máximo três componentes. Para tanto, elaborou-se um formulário próprio com a definição operacional do constructo e dos seus atributos, além da exposição dos itens propostos e as instruções para a análise de cada um dos itens, com remessa por meio eletrônico (e-mail) e obtenção da resposta com o mesmo mecanismo. Todos os juízes consultados remeteram o instrumento avaliado.

A avaliação dos itens incluiu os seguintes quesitos: (1) análise de conteúdo, com a verificação da dimensão mais adequada ao fator, e (2) análise semântica, com a verificação da compreensibilidade/incompreensibilidade dos itens. Ademais, em espaço próprio foi ofertada a possibilidade de apresentação de sugestões por parte dos especialistas. Oito 
especialistas - 6 policiais militares, estudantes ou egressos de programas de pós-graduação de diferentes áreas e departamentos da Universidade de Brasília (UnB), 1 professora da Universidade Federal de Pernambuco (UFPE) e 1 estudante do programa de pós-graduação da UnB -, foram convidados a participar do estudo, tendo recebido o formulário de avaliação dos itens propostos juntamente com um termo de participação livre e consentida. Os dados foram analisados considerando cada uma das dimensões avaliadas, como também sugestões apresentadas para reformulação dos itens.

Utilizando a proposição de Pasquali (1999), o item foi considerado adequado para o instrumento em caso de concordância de pelo menos $80 \%$ dos juízes, em cada um dos quesitos. Por outro lado, para a eliminação do item, bastava que dois dos juízes o qualificassem como incompreensível ou quando o item se encaixava em mais de um fator, em percentual superior a $20 \%$ dos juízes. Tendo por base os critérios já elencados para integração ou eliminação de itens do instrumento, praticamente todos os itens inicialmente propostos foram mantidos - apenas um dos itens foi retirado após a análise - devido à sua pertinência e relevância, sendo que do total, 12 não sofreram quaisquer alterações (63\% da quantidade inicial), 5 (26\% dos itens iniciais) foram reformulados em palavras que melhorassem o entendimento do entrevistado e 2 (11\% da quantidade inicial) foram reformulados e segmentados pela indicação dos avaliadores, resultando em 7 novos itens. A versão inicial da escala resultou em 19 itens: 6 itens para o atributo comportamental, 7 itens para o atributo afetivo e 6 itens para o atributo cognitivo ( ver Anexo).

\subsection{Procedimento de Coleta de Dados}

Este estudo é de natureza quantitativa e acredita-se que com métodos quantitativos mais avançados, como a estatística paramétrica multivariada, pode-se mostrar e mapear com mais rigor (exatidão) a influência dos valores individuais e da atitude frente à arma de fogo 
no posicionamento atitudinal dirigido ao crime. Laville e Dionne (1999) afirmam que, ao lidar com números, busca-se a objetividade e a validade do conhecimento construído. Essa estratégia foi implantada pelo método survey ou levantamento, baseado em questionários estruturados e padronizados. Os questionários foram coletados, para ambas as amostras, pessoalmente por meio de formulários de resposta impressos em papel (tipo lápis-papel).

No intuito de realizar a aplicação da pesquisa, dois auxiliares foram treinados para repassar as instruções básicas aos respondentes, como também de verificar as melhores oportunidades de preenchimento dos questionários. Com a amostra da população em geral, foram realizadas as coletas em locais de grande circulação previamente escolhidos (centro da Ceilândia, "Feira do Rolo", área comercial limítrofe ao Condomínio Sol Nascente), igrejas, lojas comerciais, além das residências de algumas pessoas. No total, foram coletados dados em 23 localidades diferentes da Ceilândia, englobando o Setor O, Condomínio Pôr-do-Sol, além do já citado Sol Nascente, setores P Sul e P Norte, dentre outros locais. Para tanto, os respondentes preenchiam o questionário na hora, durando este preenchimento cerca de 25 a 35 minutos.

Para a coleta dos dados de estudantes universitários, foi solicitada autorização à Instituição de Ensino Superior para a realização da coleta com os alunos residentes, tendo sido disponibilizado horário durante as aulas dos turnos matutino e noturno. Participaram da pesquisa estudantes universitários dos cursos de administração, gestão pública, engenharia, direito, psicologia, ciência da computação, serviço social e pedagogia. O tempo médio de aplicação do questionário foi de 20 a 30 minutos, dentro da própria sala de aula.

Foi aplicada a escala tipo likert e, respeitando suas métricas originais, aos respondentes disponibilizou-se um tempo médio de já demonstrado para responder a todo o questionário. Os dados foram analisados utilizando o AMOS (versão 18) e o SPSS 22 (Statistical Package for Social Sciences), com análise fatorial exploratória e confirmatória, e 
no intuito de aplicar as técnicas de estatística multivariada como testes-t, regressões lineares múltiplas e modelagem por equações estruturais foi seguida a recomendação de Hair et al. (2009) e Field (2009), no sentido de efetuar análise prévia dos dados para verificar a existência de discrepâncias nas médias e nos desvios padrões. A distribuição de normalidade das variáveis também foram checadas, nos moldes das recomendações de Tabachnick e Fidell (2007).

A correlação entre as variáveis do estudo é indispensável, por se tratar de um estudo exploratório, o que demonstra sua orientação à busca de entendimento mais aprofundado das variáveis do estudo e suas relações. Com relação à comparação entre as amostras, Field (2009) aponta o teste-t de Student como o mais indicado, em vista da verificação de diferença ou similaridade entre as médias dos grupos. Foram também aplicadas regressões lineares múltiplas, no intuito de investigar o poder de predição dos valores individuais frente ao medo do crime, além de análises fatoriais confirmatórias para valores e atitude frente à arma de fogo.

\subsection{Análise dos Dados}

No intuito de aplicar as técnicas de estatística multivariada como testes-t, regressões lineares e múltiplas e análise fatorial exploratória e confirmatória Tabachnick e Fidell (2007), Hair et al. (2009) e Field (2009) recomendam que seja realizada uma análise prévia dos dados para verificar a existência de discrepâncias nas médias e nos desvios padrão. Seguindo as recomendações de Tabachnick e Fidell (2007), as variáveis foram checadas quanto à sua distribuição de normalidade.

Foram seguidas três etapas para avaliação desta normalidade: (i) verificação da curva de Gauss de normalidade para cada variável estudada, cujos resultados apresentaram certa normalidade para a maioria das variáveis estabelecidas; (ii) foram utilizados os testes de Kolmogorov-Smirnov e Shapiro-Wilk, que são mais robustos (Marôco, 2011; Neiva et al., 
2007, Tabachnick \& Fidell, 2007). Os resultados rejeitaram a hipótese de normalidade, entretanto, estudos de simulação (e.g., Refinetti, 1996) vêm demonstrando que os métodos paramétricos são robustos à violação do pressuposto de normalidade, desde que as distribuições não sejam muito enviesadas e achatadas e as amostras não sejam extremamente pequenas $(\mathrm{n}<100)$.

Foi realizado uma análise fatorial exploratória da Escala do Medo do Crime, para posterior confirmação fatorial, através do AMOS (versão 18). Considerou-se a matriz de covariâncias como entrada, tendo sido adotado o parâmetro Maximum Likelihook para o teste Qui-quadrado, responsável por averiguar a probabilidade de ajuste do modelo teórico aos dados. Foi considerado, em virtude de sua sensibilidade ao tamanho da amostra, a razão em relação aos graus de liberdade $\left(\chi^{2} /\right.$ g.1.), cujos valores considerados no intervalo entre 1 e 3 são considerados satisfatórios; para o Goodness-of-Fit Index (GFI), que trata da proporção de variância-covariância nos dados, o que o torna semelhante ao $\mathrm{R}^{2}$ em regressão múltipla. Os valores variam de 0 a 1 , em torno de 0,90 ou superiores indicando um ajustamento adequado (Byrne, 2010; Marôco, 2010; Tabachnick \& Fidell, 2007). Foi utilizado para a verificação de um índice comparativo e adicional de ajuste ao modelo, o Comparative Fit Index (CFI), em que valores mais próximos de 1 indicavam melhor ajuste; recomendam-se valores de 0,90 ou superiores; assim como, a Root-Mean-Square Error of Approximation (RMSEA), com seu intervalo de confiança de 90\% (IC90\%); analisado para valores inferiores a 0,08, mesmo aceitando-se valores próximos de 0,10 (Byrne, 2010; Marôco, 2010; Tabachnick \& Fidell, 2007). Por fim, foi analisado o Standardized Root Mean Square Residual (SRMR), como uma medida absoluta de ajuste, definida como a diferença normalizada entre a correlação observada e a correlação previsível. Um valor inferior a 0,08 é considerado geralmente um bom ajuste (Hu \& Bentler, 1999). 
Para averiguar a predição do Medo do Crime e da Atitude Frente à Arma de Fogo pelos Valores Humanos, foram seguidos os passos de Allen (2000) e Torres e Allen (2009), que utilizaram regressões lineares múltiplas com método de entrada de variáveis do tipo enter, para ambas as amostras. Field (2009) aponta que essa regressão é adotada quando se quer verificar o poder explicativo das variáveis independentes em grupo frente à variável independente. Assim, foi investigado o poder de predição dos Valores Humanos frente ao medo do crime e a atitude frente à arma de fogo, bem como de dados sociodemográficos o poder de predição de dados sociodemográficos. Ademais, foi realizada a comparação de médias para verificar se há diferença entre as amostras estabelecidas e o medo do crime.

A seguir, serão externados os resultados alcançados neste trabalho. 


\section{Capítulo 4}

\section{Resultados}

\subsection{Apresentação das Amostras e Análises Preliminares}

O objetivo principal da pesquisa é compreender como os valores humanos individuais e a atitude frente à arma de fogo influenciam o medo do crime na Região Administrativa de Ceilândia, no Distrito Federal. Para tanto, foram coletados 1.076 questionários, entre os quais trinta e cinco foram preenchidos pela metade, decidindo-se pela desconsideração destes questionários parcialmente respondidos, em razão de sua incompletude, além de não trazerem impacto sobre a amostra realizada, restando ao final 1.041 questionários.

Como não é recomendável que a análise exploratória e confirmatória sejam realizadas com o mesmo conjunto de dados, foi escolhida aleatoriamente uma das amostras, utilizando o programa Microsoft Excel Office 2016. Foi mantido o preceito de contar com pelo menos 10 respondentes por item, tanto na fase exploratória quanto na confirmatória (Pasquali, 2006; Hair et al., 2009). Assim, o banco foi partilhado em duas amostras, uma correspondente à população residente da Ceilândia (amostra $1, n=522$ ) e a outra correspondente a estudantes universitários residentes na Ceilândia (amostra 2, n=519), que passaram por adequações para a realização das análises multivariadas.

Para a realização da análise dos dados coletados é imprescindível verificar a adequação dos dados para a análise multivariada, que consiste em examinar os valores ausentes e extremos (outliers), a normalidade dos dados e a ausência de multicolinearidade (Kline, 2010). Neiva, Abbad e Tróccoli (2007), reforçam a importância da análise do valor ausente no intuito de eliminar problemas, em casos específicos, com a substituição dos dados ausentes que podem afetar a normalidade e a homocedasticidade. A análise de frequências e de valores ausentes constatou um percentual menor que 3\% e aleatoriamente distribuídos, 
possibilitando sua substituição pela média, conforme indicações de Tabachnick e Fidell (2007).

Os valores extremos - ou outliers -, por sua vez foram investigados, em cada uma das amostras, com base nos critérios da distância de Mahalanobis e na distância de Cook (Hair et al., 2009; Neiva et al., 2007), estabelecendo-se a exclusão de 108 observações na amostra 1 (população em geral) e 99 na amostra 2 (estudantes universitários). A amostra final foi composta por 834 respondentes, suficiente para atender aos critérios empregados sobre o tamanho das amostras.

Para avaliar o pressuposto de normalidade dos dados foram utilizados os testes de Kolmogorov-Smirnov e Shapiro-Wilk, que são mais poderosos (Marôco, 2011; Neiva et al., 2007, Tabachnick \& Fidell, 2007). Os resultados rejeitam a normalidade dos dados (para o conjunto das variáveis $0,104<\mathrm{D}(834)<0,476 ; \mathrm{p}<0,000)$.

\subsection{Análise Descritiva}

A amostra da população geral da Ceilândia apresentou média de 32,26 anos $(\mathrm{dp}=0,50)$, com 55,8\% de mulheres, $51,0 \%$ solteiros, $25,2 \%$ razoavelmente religiosos, $43 \%$ se consideram numa classe econômica média-baixa. Já a amostra dos estudantes universitários apresentou média de 26,03 anos ( $d p=7,09)$, com $54 \%$ de mulheres, $67,6 \%$ solteiros, $51,2 \%$ muito ou totalmente religiosos, $45 \%$ se consideram numa condição econômica bastante baixa.

Em uma exposição acerca da escolaridade, 78,2\% dos respondentes da população em geral não são graduandos ou graduados (ensino fundamental e médio), enquanto $100 \%$ dos estudantes universitários estão realizando ou já concluíram a graduação. Os dados sociodemográficos coletados são estabelecidos na Tabela 11. 
Tabela 11

Distribuição dos dados sociodemográficos

\begin{tabular}{|c|c|c|c|c|c|c|c|}
\hline \multirow[b]{2}{*}{ Variáveis } & \multirow[b]{2}{*}{ Níveis } & \multicolumn{2}{|c|}{$\begin{array}{c}\text { Amostra } 1 \\
(n=414)\end{array}$} & \multicolumn{2}{|c|}{$\begin{array}{c}\text { Amostra } 2 \\
(n=420)\end{array}$} & \multicolumn{2}{|c|}{$\begin{array}{c}\text { População } \\
(\mathrm{N}=489.351)\end{array}$} \\
\hline & & Frequências & $\%$ & Frequências & $\%$ & Frequências & $\%$ \\
\hline \multirow[t]{3}{*}{ Sexo } & Masculino & 183 & $44,2 \%$ & 193 & $46,00 \%$ & 235.782 & $48,2 \%$ \\
\hline & Feminino & 231 & $55,8 \%$ & 227 & $54,00 \%$ & 253.569 & $51,8 \%$ \\
\hline & Solteiro(a) & 211 & $51,0 \%$ & 284 & $67,60 \%$ & 131.820 & $26,9 \%$ \\
\hline \multirow[t]{5}{*}{ Estado Civil } & Casado(a) & 161 & $38,9 \%$ & 115 & $27,40 \%$ & 107.422 & $22,0 \%$ \\
\hline & $\begin{array}{c}\text { Divorciado(a) / } \\
\text { Separado(a) }\end{array}$ & 23 & $5,6 \%$ & 17 & $4,00 \%$ & 15.123 & $3,1 \%$ \\
\hline & Outro & 19 & $4,6 \%$ & 4 & $1,00 \%$ & 72.966 & $14,9 \%$ \\
\hline & $\begin{array}{c}\text { Não sabem ler ou } \\
\text { escrever }\end{array}$ & - & - & - & - & 17.510 & $3,6 \%$ \\
\hline & Ensino Fundamental & 116 & $28,0 \%$ & - & - & 203.307 & $41,5 \%$ \\
\hline \multirow[t]{7}{*}{ Escolaridade } & Ensino Médio & 208 & $50,2 \%$ & - & - & 156.728 & $32,0 \%$ \\
\hline & Graduação & 70 & $16,9 \%$ & 412 & $98,10 \%$ & 54.056 & $11,0 \%$ \\
\hline & Especialização & 18 & $4,3 \%$ & 5 & $1,20 \%$ & 1.962 & $0,4 \%$ \\
\hline & Mestrado & 2 & $0,5 \%$ & 3 & $0,70 \%$ & 234 & $0,0 \%$ \\
\hline & Doutorado & - & - & - & - & 234 & $0,0 \%$ \\
\hline & Nada Religioso & 48 & $11,6 \%$ & 47 & $11,20 \%$ & 25.582 & $5,2 \%$ \\
\hline & Pouco Religioso & 57 & $13,8 \%$ & 36 & $8,60 \%$ & - & - \\
\hline \multirow[t]{4}{*}{ Religiosidade } & $\begin{array}{c}\text { Razoavelmente } \\
\text { Religioso }\end{array}$ & 105 & $25,4 \%$ & 122 & $29,00 \%$ & 50.027 & $10,2 \%$ \\
\hline & Muito Religioso & 92 & $22,2 \%$ & 103 & $24,50 \%$ & 412758 & $84,3 \%$ \\
\hline & $\begin{array}{l}\text { Totalmente } \\
\text { Religioso }\end{array}$ & 112 & $27,1 \%$ & 112 & $26,70 \%$ & - & - \\
\hline & Baixa & 53 & $12,8 \%$ & 26 & $6,20 \%$ & & \\
\hline \multirow{5}{*}{$\begin{array}{c}\text { Classe } \\
\text { Econômica } \\
\text { Comparada }\end{array}$} & Média-Baixa & 178 & $43,0 \%$ & 163 & $38,80 \%$ & & \\
\hline & Média & 173 & $41,8 \%$ & 196 & $46,70 \%$ & & \\
\hline & $\begin{array}{c}\text { Média-Alta } \\
\text { Alta }\end{array}$ & 10 & $2,4 \%$ & 35 & $8,30 \%$ & & \\
\hline & 18 anos ou menos & 66 & $15,9 \%$ & 19 & $4,50 \%$ & 137.561 & $28,1 \%$ \\
\hline & $19-24$ anos & 84 & $20,3 \%$ & 205 & $48,80 \%$ & 43.152 & $8,8 \%$ \\
\hline \multirow[t]{4}{*}{ Faixa Etária } & $25-39$ anos & 144 & $34,8 \%$ & 176 & $41,90 \%$ & 11.291 & $2,3 \%$ \\
\hline & $40-59$ anos & 109 & $26,3 \%$ & 20 & $4,80 \%$ & 114.660 & $23,4 \%$ \\
\hline & $60-64$ anos & 8 & $1,9 \%$ & & & 24.644 & $5,0 \%$ \\
\hline & 65 anos ou mais & 3 & $0,7 \%$ & & & 58.043 & $11,9 \%$ \\
\hline
\end{tabular}

Fonte: Dados da Pesquisa. 


\subsection{Evidências de Validade da Escala de Medo do Crime}

A Escala de Medo do Crime (EMC), estabelecida com base nos estudos de Jackson (2008), seguiu os procedimentos de elaboração elencados por Pasquali (2010), foram atendidos no que se refere aos procedimentos teóricos e empíricos, restando o polo analítico voltado neste trabalho à validação psicométrica da medida. Para tanto, foi elaborada a análise fatorial exploratória, para ambas as amostras, e confirmatória, para uma das amostras, deste instrumento de medida.

\subsubsection{Análise fatorial exploratória com Software SPSS Statistics}

Em análise preliminar dos Componentes Principais (PC), a matriz de intercorrelações para a amostra da população em geral (amostra 1, n=414) mostrou-se fatorizável, isto é, apresentou suficiente covariância que permitisse a procura de fatores. O teste de esfericidade de Bartlett $(\mathrm{p}<0,000)$ e o coeficiente KMO, que indicam tal evento, foi de 0,86 que pode ser considerado meritório, quase maravilhoso (Pasquali, 2010; Kaiser, 1974).

Em seguida, foi analisada a dimensionalidade da escala com base em diferentes métodos. O critério de Kaiser identificou até cinco fatores que explicam $51,60 \%$ da variância total. Por fim, realizou-se a Análise Paralela de Horn, que identificou até três fatores. Esses critérios estão descritos na Tabela 12.

\section{Tabela 12}

Autovalores empíricos e aleatórios da EMC (amostra 2)

\begin{tabular}{cccc}
\hline \multirow{2}{*}{ Componente } & \multicolumn{2}{c}{ Autovalores iniciais } & \multirow{2}{*}{ Autovalores aleatórios } \\
\cline { 2 - 3 } & Total & \% de variância & 1,3958 \\
2 & 4,716 & 24,82 & 1,3206 \\
3 & 1,693 & 8,91 & 1,2648 \\
4 & 1,297 & 6,82 & 1,2171 \\
5 & 1,056 & 5,56 & 1,1724 \\
\hline
\end{tabular}

Fonte: Dados da pesquisa. 
De posse dessas informações, procedeu-se à análise fatorial pelo método dos eixos principais $(P A F)$, com rotação promax, para a extração de três fatores, que se mostrou mais adequada à teoria. Foi excluído o item que saturou em mais de um fator (MC18) com diferença inferior a 0,1 (Neiva et al., 2007). O item MC19 apresentou carga fatorial abaixo do limite de 0,30 , por isso foi excluído. Foram mantidos os itens que apresentaram baixas comunalidades $(<0,3)$ com carga fatorial acima de 0,30 , com respaldo no modelo teórico utilizado.

A nova análise melhorou a representatividade dos itens que passaram a explicar 46,99\% da variância total. A análise de precisão foi obtida pelos coeficientes alfa de Cronbach e lambda-2 de Guttman, sendo excluído o item MC03 pelo critério da parcimônia (Pasquali, 2006), com vistas a aumentar a confiabilidade do fator. A estrutura final da EMC, para a amostra $1(\mathrm{n}=414)$, portanto, reteve os itens que apresentaram compatibilidades teóricas e parcimônia. A Tabela 13 disponibiliza uma síntese dos resultados finais retidos da análise fatorial exploratória.

Tabela 13

Matriz fatorial da EMC (amostra 1)

\begin{tabular}{|c|c|c|c|c|}
\hline Itens & Fator 1 & Fator 2 & Fator 3 & Comunalidades $\left(\mathrm{R}^{2}\right)$ \\
\hline $\mathrm{MC04}$ & 0,82 & & & 0,47 \\
\hline MC02 & 0,71 & & & 0,45 \\
\hline MC05 & 0,57 & & & 0,36 \\
\hline MC07 & 0,57 & & & 0,30 \\
\hline MC08 & 0,52 & & & 0,32 \\
\hline MC09 & 0,51 & & & 0,34 \\
\hline MC15 & & 0,57 & & 0,31 \\
\hline MC16 & & 0,55 & & 0,27 \\
\hline MC13 & & 0,54 & & 0,15 \\
\hline MC17 & & 0,47 & & 0,36 \\
\hline MC12 & & & 0,53 & 0,16 \\
\hline $\mathrm{MC} 01$ & & & 0,46 & 0,13 \\
\hline $\mathrm{MC} 06$ & & & 0,40 & 0,15 \\
\hline Autovalor & 3,72 & 1,59 & 1,27 & \\
\hline Número de itens & 6 & 4 & 3 & \\
\hline $\begin{array}{l}\text { \% da Var. } \\
\text { Explicada }\end{array}$ & 26,57 & 11,35 & 9,07 & \\
\hline
\end{tabular}




\begin{tabular}{cccc} 
Alfa & 0,78 & 0,65 & 0,44 \\
Lambda 2 & 0,79 & 0,66 & 0,49 \\
\hline
\end{tabular}

Fonte: Dados da pesquisa.

Os três fatores da EMC estão suficientemente estruturados, com ressalva ao Fator 3, que necessita de maior consistência interna, estando abaixo dos parâmetros utilizados (Pasquali, 2006). A AFE dos dados redistribuiu os itens em três fatores, que foram renomeados, buscando-se a adequação com a teoria de base.. Os novos fatores renomeados, passaram a ser designados da forma seguinte:

- Fator 1: denominado Afeto, referindo-se ao aspecto do medo do crime que envolve emoções diferentes em relação à possibilidade de vitimização, que incluem respostas físicas à ameaça imediata - o que Jackson (2015) chama de "medo específico", um padrão mais geral de pensamentos repetitivos sobre o futuro dano incerto ("preocupação") e uma emoção de nível mais difuso que se afasta dos sentimentos concretos de perigo iminente (algo que se aproxima de "ansiedade").

- Fator 2: chamado de Cognição, volta-se à percepção da probabilidade de vitimização, é o medo do crime acionado a partir de cognições efetuadas pelo indivíduo, através de uma sensação real de risco, de ameaça e constatação de vulnerabilidade, composta pela percepção de consequência e controle. Integram este fator a probabilidade percebida de vitimização, percepção de gravidade de determinados crimes e a percepção subjetiva de sua ocorrência (consigo e com outros indivíduos).

- Fator 3: denominado Comportamento, é um posicionamento ou resposta ao risco percebido de vitimização e medo do crime ligado à evitação, proteção, ajustes de estilo de vida e participação (ou ausência) de participação em atividades coletivas relevantes. É relevante na pesquisa sobre o medo do crime pelo potencial de desenvolvimento do efeito bumerangue: um maior medo pode resultar em níveis maiores de isolamento que, por sua vez, níveis estes que repercutem patamares maiores de medo. 
Apresenta-se, em seguida, a análise fatorial confirmatória voltada à comprovação da estruturada alcançada com a AFE.

\subsubsection{Análise fatorial confirmatória com Software AMOS}

Para elaborar essa estimação, foram seguidas as recomendações de Marôco (2010) que aponta que o modelo mais tradicional e mais utilizado para análise fatorial confirmatória é o de Máxima Verossimilhança (ML) ou Maximum Likelihood. Brown (2006) reforça que os pressupostos fundamentais da ML são o tamanho grande da amostra, a distribuição multivariadas dos dados e o fato das variáveis serem contínuas.

Quanto ao tamanho da amostra, 420 estudantes universitários residentes da Ceilândia (amostra 2) atendem o pressuposto de tamanho da amostra, uma vez que Hair et al. (2009) recomendam que o tamanho ideal para realizar modelagem por equações estruturais é de pelo menos 200. Os dados foram coletados aplicando escalas tipo likert, atendendo ao pressuposto de variáveis contínuas. A escala de medo do crime, composta por 19 itens, apresentou distribuição fatorial após a AFE para 13 itens, sendo os fatores afeto, cognição e comportamento compostos por 6,4 e 3 itens, respectivamente.

Marôco (2010) recomenda que se observe o CFI (Comparative Fit Index), pois compara o ajustamento do modelo em estudo $\left(\mathrm{X}^{2}\right)$ com graus de liberdade com modelo basal $\left(\mathrm{X}^{2} \mathrm{~b}\right)$ e com graus de liberdade G.Lb, o que significa uma comparação entre o modelo completamente independente e o correlacionado. Um CFI maior ou igual a 0,90 indica bom ajustamento do modelo. Outro índice recomendado por Marôco (2010) é o RMSEA (Root Mean Square Error of Approximation), pois, de maneira geral, afirma que a adição de variáveis em um modelo melhora a estimação dos índices e o RMSEA apresenta um índice que penaliza a adição de graus de liberdade para compensar a melhoria obtida pela simples adição destes. 
Marôco (2010) sugere que o RMSEA é bom para valores abaixo de 0,08 e muito bom quando abaixo de 0,05. Marôco (2010) aponta que é interessante observar o SRMR (Standardized Root Mean Square Residual), a raiz quadrada da matriz dos erros divida pelos graus de liberdade, assumindo que o modelo ajustado é o correto; um SRMR equivalente a 0 indica ajuste perfeito do modelo, SRMR abaixo ou igual a 0,05 indica excelente ajuste, valores entre 0,05 e 0,08 indicam bons ajustes e valores superiores a 0,1 indicam ajustes inadequados. Por fim, outro indicador de ajuste refere-se ao $\mathrm{X}^{2} / \mathrm{G}$.L (Qui-quadrado dividido por graus de liberdade), e Marôco 2010 aponta que valores entre 2 e 5 são aceitáveis, inferiores a 2 bons e acima de 5 inaceitáveis.

A análise confirmatória para a Escala do Medo do Crime utilizou a amostra dos estudantes universitários (amostra 2) e resultou em $X^{2} / G . L$ acima de 2,0 - $X^{2} / G . L=3,35$, $\mathrm{p}<0,000$ - o que indica ajuste aceitável da estrutura. Os índices de ajuste foram considerados bons, com $\mathrm{CFI}=0,92, \mathrm{RMSEA}=0,075(\mathrm{IC} 90 \%=0,061-0,089), \mathrm{SRMR}=0,054$, que indicaram a estrutura confirmatória dos fatores. A Figura 6 apresenta a estrutura confirmatória da Escala de Medo do Crime, com os pesos fatoriais não padronizados e as correlações múltiplas ao quadrado. 


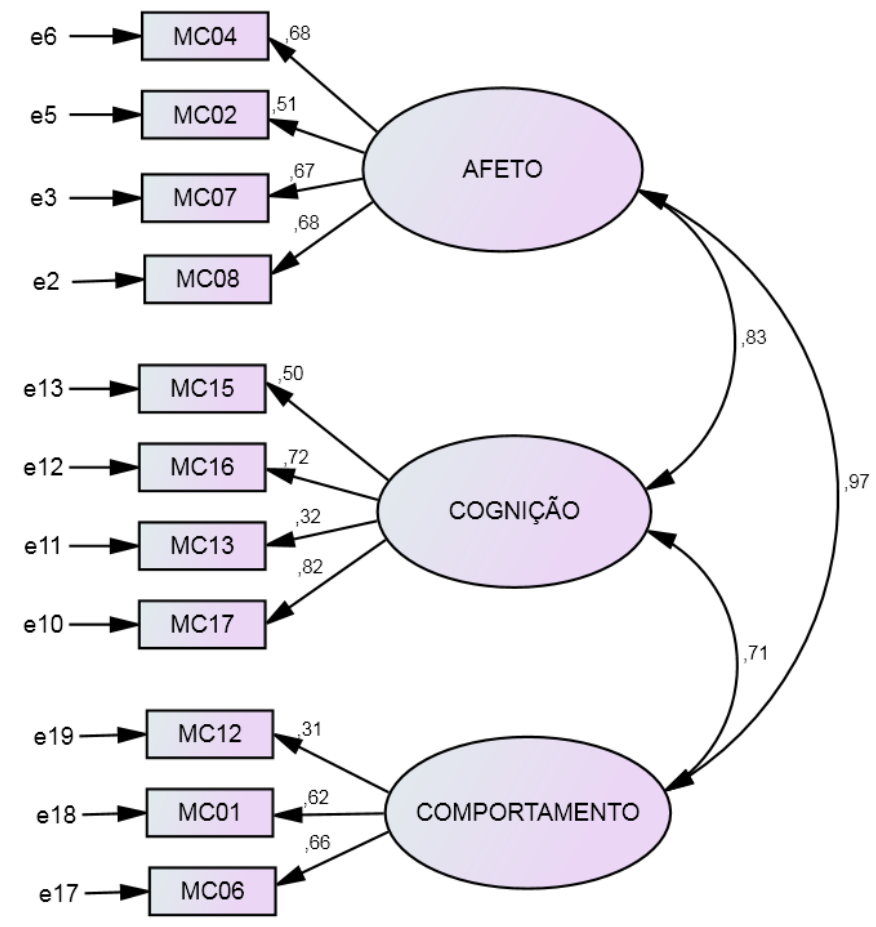

Figura 6. Estrutura fatorial da Escala do Medo do Crime (EMC)

A Tabela 14 apresenta os índices de estimação do modelo teórico da Escala de Medo do Crime, em seus respectivos fatores com a amostra de estudantes universitários residentes na Ceilândia.

Tabela 14

Índices de estimação do modelo teórico da Escala de Medo do Crime

\begin{tabular}{|c|c|c|c|c|c|}
\hline Itens & Estimação & $\begin{array}{c}\text { Erros } \\
\text { padronizados } \\
\text { (S.E.) }\end{array}$ & C.R. & P-valor & $\begin{array}{l}\text { Estimação da } \\
\text { regressão } \\
\text { padronizada }\end{array}$ \\
\hline \multicolumn{6}{|c|}{ Afeto } \\
\hline MC04 & 0,67 & 0,06 & 11,88 & 0 & 0,68 \\
\hline $\mathrm{MC02}$ & 0,48 & 0,05 & 9,10 & 0 & 0,51 \\
\hline MC07 & 1,20 & 0,10 & 12,13 & 0 & 0,67 \\
\hline MC08 & 1,00 & & & & 0,68 \\
\hline \multicolumn{6}{|c|}{ Cognição } \\
\hline MC16 & 0,74 & 0,05 & 13,63 & 0 & 0,72 \\
\hline MC15 & 0,43 & 0,05 & 9,44 & 0 & 0,50 \\
\hline MC13 & 0,44 & 0,07 & 6,03 & 0 & 0,32 \\
\hline MC17 & 1,00 & & & & 0,82 \\
\hline \multicolumn{6}{|c|}{ Comportamento } \\
\hline MC16 & 0,28 & 0,06 & 5,08 & 0 & 0,31 \\
\hline MC15 & 0,99 & 0,10 & 10,33 & 0 & 0,62 \\
\hline
\end{tabular}


Fonte: Dados da pesquisa

Em situações como esta de $\mathrm{X}^{2} / \mathrm{G} . \mathrm{L}>$ 2,0 Marôco (2010) recomenda observar os índices de modificação (Modification Indeces), uma vez que estes apontam a redução conservadora do $\mathrm{X}^{2}$ do modelo se um parâmetro fixo ou uma igualdade de parâmetros for liberado, se erros de medida forem correlacionados depois da reestimação do modelo, posicionamento que justificou o descarte dos itens MC05 e MC09 do modelo.

Todas as variáveis inseridas são significativas pois seu p-valor foi abaixo de 0,05 , como aponta Marôco (2010), e o critical ratio (C.R.) atendeu ao padrão estabelecido por Byrne (2010) que destaca que este deve ser superior a 1,96.

\subsubsection{Análise confirmatória dos Valores Humanos Individuais}

Após a análise confirmatória dos fatores do medo do crime que compõe o modelo geral estudado, foi realizada a análise fatorial confirmatória (AFC) dos Valores Humanos Individuais, pois ainda que esta já tenha sido realizada por Torres et al. (2016) com resultados excelentes, é relevante para o entendimento não só da variável estabelecida como também das amostras estudadas. Para tanto, os valores foram estabelecidos em sua divisão de $1^{\text {a }}$ ordem (19 tipos motivacionais), em quatro grandes divisões referentes à estrutura dos tipos motivacionais de $2^{\mathrm{a}}$ ordem (Schwartz et al., 2012).

Uma vez mais utilizando a amostra de estudantes universitários (amostra 2), foram obtidos os resultados seguintes, de acordo com as organizacionais por tipos motivacionais propostas por Schwartz et al. (2012):

- Conservação: tipo motivacional de $2^{\mathrm{a}}$ ordem constituído pelos tipos motivacionais de $1^{\mathrm{a}}$ ordem conformidade interpessoal, conformidade às regras, humildade, segurança pessoal, segurança social e tradição, cuja análise confirmatória apresentou os resultados de 
$\mathrm{X}^{2} / \mathrm{G} . \mathrm{L}$ acima de $2,0-\mathrm{X}^{2} / \mathrm{G} . \mathrm{L}=3,12, \mathrm{p}<0,000-\mathrm{o}$ que indica ajuste aceitável da estrutura. Os índices de ajuste foram considerados bons, com CFI=0,92, RMSEA=0,071 (IC90\%=0,062$0,080)$ e $\mathrm{SRMR}=0,055$;

- Autotranscendência: tipo motivacional de $2^{\mathrm{a}}$ ordem constituído pelos tipos motivacionais de $1^{\mathrm{a}}$ ordem benevolência cuidado, benevolência dependência, universalismo tolerância, universalismo natureza e universalismo compromisso, em sua análise confirmatória apresentou $\mathrm{X}^{2} / \mathrm{G} . \mathrm{L}=2,69, \mathrm{p}<0,000$ - o que indica ajuste aceitável da estrutura. Os índices de ajuste foram considerados muito bons, com $\mathrm{CFI}=0,96$, RMSEA=0,071 $(\mathrm{IC} 90 \%=0,053-0,074)$ e $\mathrm{SRMR}=0,040$;

- Autopromoção: tipo motivacional de $2^{\mathrm{a}}$ ordem constituído pelos tipos motivacionais de $1^{\mathrm{a}}$ ordem face, poder domínio, poder sobre os recursos e realização, em sua análise confirmatória apresentou $\mathrm{X}^{2} / \mathrm{G} . \mathrm{L}=4,88, \mathrm{p}<0,000$ - o que indica ajuste aceitável da estrutura $(<5)$. Os índices de ajuste foram aceitáveis, com $\mathrm{CFI}=0,88, \mathrm{RMSEA}=0,071$ $(\mathrm{IC} 90 \%=0,053-0,074)$ e $\mathrm{SRMR}=0,064$;

- Abertura à mudança: tipo motivacional de $2^{\mathrm{a}}$ ordem constituído pelos tipos motivacionais de $1^{\mathrm{a}}$ ordem hedonismo, estimulação, autodireção pensamento e autodireção ação, em sua análise confirmatória apresentou $X^{2} / G . L=3,33, p<0,000-$ o que indica ajuste aceitável da estrutura. Os índices de ajuste foram considerados bons, com $\mathrm{CFI}=0,95$, RMSEA $=0,075($ IC90\%=0,061-0,089) e SRMR $=0,044$.

Ademais, a Tabela 15 apresenta os índices de estimação dos tipos motivacionais de $1^{\mathrm{a}}$ ordem, organizados por tipos motivacionais de $2^{\mathrm{a}}$ ordem, consoante a Teoria Refinada de Valores de Schwartz, em seus respectivos fatores.

Tabela 15

Índices de estimação dos tipos motivacionais de $2^{a}$ ordem da Teoria Refinada de Valores de Schwartz

\begin{tabular}{|c|c|c|c|c|c|}
\hline Itens & Estimação & $\begin{array}{c}\text { Erros } \\
\text { padronizados } \\
\text { (S.E.) }\end{array}$ & C.R. & P-valor & $\begin{array}{l}\text { Estimação da } \\
\text { regressão padronizada }\end{array}$ \\
\hline
\end{tabular}




\begin{tabular}{|c|c|c|c|c|c|}
\hline \multicolumn{6}{|c|}{ Conservação } \\
\hline \multicolumn{6}{|c|}{ Humildade } \\
\hline HUM1 & 1,00 & & & & 0,38 \\
\hline HUM2 & 1,43 & 0,19 & 7,34 & 0 & 0,74 \\
\hline HUM3 & 1,00 & 0,18 & 5,50 & 0 & 0,37 \\
\hline \multicolumn{6}{|c|}{ Tradição } \\
\hline TR1 & 1,00 & & & & 0,38 \\
\hline TR2 & 1,43 & 0,19 & 7,34 & 0 & 0,74 \\
\hline TR3 & 1,00 & 0,18 & 5,50 & 0 & 0,37 \\
\hline \multicolumn{6}{|c|}{ Conformidade Interpessoal } \\
\hline COI1 & 1,00 & & & & 0,58 \\
\hline COI2 & 1,26 & 0,13 & 9,88 & 0 & 0,71 \\
\hline $\mathrm{COI} 3$ & 1,37 & 0,14 & 10,16 & 0 & 0,77 \\
\hline \multicolumn{6}{|c|}{ Conformidade às Regras } \\
\hline COR1 & 1,00 & & & & 0,59 \\
\hline COR2 & 1,33 & 0,12 & 11,13 & 0 & 0,71 \\
\hline COR3 & 0,70 & 0,11 & 6,14 & 0 & 0,38 \\
\hline \multicolumn{6}{|c|}{ Segurança Pessoal } \\
\hline SEP1 & 1,00 & & & & 0,64 \\
\hline SEP2 & 1,21 & 0,10 & 12,45 & 0 & 0,83 \\
\hline \multicolumn{6}{|c|}{ Segurança Social } \\
\hline SES1 & 1,00 & & & & 0,66 \\
\hline SES2 & 1,26 & 0,10 & 13,07 & 0 & 0,79 \\
\hline SES3 & 1,24 & 0,10 & 11,96 & 0 & 0,70 \\
\hline & & & & & $\begin{array}{r}\text { (continua) } \\
\text { (continuação) }\end{array}$ \\
\hline \multicolumn{6}{|c|}{ Autotranscendência } \\
\hline \multicolumn{6}{|c|}{ Universalismo Tolerância } \\
\hline UNT1 & 1,00 & & & & 0,58 \\
\hline UNT2 & 1,26 & 0,11 & 11,29 & 0 & 0,81 \\
\hline UNT3 & 1,23 & 0,12 & 10,47 & 0 & 0,70 \\
\hline \multicolumn{6}{|c|}{ Universalismo Natureza } \\
\hline UNN1 & 1,00 & & & & 0,76 \\
\hline UNN2 & 0,93 & 0,07 & 13,53 & 0 & 0,73 \\
\hline UNN3 & 1,04 & 0,07 & 14,00 & 0 & 0,77 \\
\hline \multicolumn{6}{|c|}{ Universalismo Compromisso } \\
\hline UNN1 & 1,00 & & & & 0,60 \\
\hline UNN2 & 1,08 & 0,09 & 11,69 & 0 & 0,72 \\
\hline UNN3 & 1,24 & 0,10 & 11,93 & 0 & 0,75 \\
\hline \multicolumn{6}{|c|}{ Benevolência Dependência } \\
\hline BED1 & 1,00 & & & & 0,73 \\
\hline BED2 & 1,08 & 0,07 & 15,83 & 0 & 0,83 \\
\hline BED3 & 0,81 & 0,07 & 12,34 & 0 & 0,59 \\
\hline \multicolumn{6}{|c|}{ Benevolência Cuidado } \\
\hline BEC1 & 1,00 & & & & 0,73 \\
\hline BEC2 & 1,12 & 0,07 & 17,18 & 0 & 0,85 \\
\hline $\mathrm{BEC} 3$ & 1,00 & 0,07 & 14,04 & 0 & 0,70 \\
\hline \multicolumn{6}{|c|}{ Autopromoção } \\
\hline \multicolumn{6}{|c|}{ Face } \\
\hline $\mathrm{FAC} 1$ & 1,00 & & & & 0,62 \\
\hline FAC2 & 1,00 & 0,11 & 8,88 & 0 & 0,64 \\
\hline FAC3 & 1,14 & 0,13 & 8,87 & 0 & 0,64 \\
\hline \multicolumn{6}{|c|}{ Poder Recursos } \\
\hline POR1 & 1,00 & & & & 0,77 \\
\hline POR2 & 0,69 & 0,07 & 9,78 & 0 & 0,53 \\
\hline POR3 & 0,94 & 0,07 & 13,26 & 0 & 0,72 \\
\hline
\end{tabular}




\begin{tabular}{|c|c|c|c|c|c|}
\hline \multicolumn{6}{|c|}{ Poder Domínio } \\
\hline POD1 & 1,00 & & & & 0,45 \\
\hline POD2 & 1,57 & 0,20 & 7,75 & 0 & 0,74 \\
\hline POD3 & 1,25 & 0,16 & 7,91 & 0 & 0,57 \\
\hline \multicolumn{6}{|c|}{ Realização } \\
\hline $\mathrm{AC} 1$ & 1,00 & & & & 0,59 \\
\hline $\mathrm{AC} 2$ & 1,28 & 0,12 & 10,40 & 0 & 0,75 \\
\hline $\mathrm{AC} 3$ & 1,21 & 0,12 & 9,75 & 0 & 0,66 \\
\hline \multicolumn{6}{|c|}{ Abertura à Mudança } \\
\hline \multicolumn{6}{|c|}{ Hedonismo } \\
\hline HE1 & 1,00 & & & & 0,54 \\
\hline HE2 & 1,41 & ,138 & 10,21 & 0 & 0,77 \\
\hline HE3 & 1,45 &, 156 & 9,30 & 0 & 0,64 \\
\hline \multicolumn{6}{|c|}{ Estimulação } \\
\hline ST2 & 1,00 & & & & 0,64 \\
\hline ST3 & 1,01 &, 113 & 8,91 & 0 & 0,53 \\
\hline \multicolumn{6}{|c|}{ Autodireção Ação } \\
\hline SAD1 & 1,00 & & & & 0,78 \\
\hline SAD2 & 0,91 &, 071 & 12,89 & 0 & 0,62 \\
\hline SAD3 & 1,02 & 061 & 16,89 & 0 & 0,78 \\
\hline \multicolumn{6}{|c|}{ Autodireção Pensamento } \\
\hline SDT1 & 1,00 & & & & 0,62 \\
\hline SDT2 & 1,12 & 0,09 & 13,16 & 0 & 0,83 \\
\hline SDT3 & 0,98 & 0,08 & 11,72 & 0 & 0,70 \\
\hline
\end{tabular}

Fonte: Dados da pesquisa.

Nesta análise, assim como no modelo estabelecido por Schwartz et al. (2012), posteriormente ratificado no Brasil por Torres et al. (2016), foram descartados os itens SEP3 e STI1, no intuito de potencializar o ajuste do modelo. Todas as variáveis inseridas foram significativas, pois seu p-valor foi abaixo de 0,05 como aponta Marôco (2010), e o critical ratio (C.R.) atendeu ao padrão estabelecido por Byrne (2010) que destaca que este deve ser superior a 1,96. Os resultados alcançados confirmam a estrutura dos estudos originais.

\subsubsection{Análise confirmatória da Atitude Frente à Arma de Fogo}

Com argumento semelhante ao utilizado para os valores humanos individuais, foi realizada a análise confirmatória do modelo de atitude frente à arma de fogo, proposto por Nascimento et al. (2016), com a utilização da amostra de estudantes universitários (amostra 2), obtiveram-se os índices apresentados na Tabela 16, de acordo com o modelo proposto pelos autores. 
Tabela 16

Índices de estimação do Escala de Atitude Frente à Arma de Fogo

\begin{tabular}{|c|c|c|c|c|c|}
\hline Itens & Estimação & $\begin{array}{c}\text { Erros } \\
\text { padronizados } \\
\text { (S.E.) } \\
\end{array}$ & C.R. & P-valor & $\begin{array}{l}\text { Estimação da } \\
\text { regressão } \\
\text { padronizada }\end{array}$ \\
\hline \multicolumn{6}{|c|}{ Direitos } \\
\hline AFAF07 & 0,80 & 0,05 & 17,97 & 0 & 0,68 \\
\hline AFAF15 & 0,82 & 0,05 & 17,30 & 0 & 0,51 \\
\hline AFAF11 & 0,73 & 0,04 & 18,07 & 0 & 0,67 \\
\hline AFAF10 & 0,72 & 0,04 & 16,44 & 0 & 0,68 \\
\hline AFAF08 & 0,91 & 0,04 & 22,07 & 0 & \\
\hline AFAF06 & 1,03 & 0,03 & 36,91 & & \\
\hline AFAF05 & 1,00 & & & & \\
\hline \multicolumn{6}{|c|}{ Crime } \\
\hline AFAF12 & 0,79 & 0,06 & 13,38 & 0 & 0,72 \\
\hline AFAF17 & 0,84 & 0,06 & 14,25 & 0 & 0,50 \\
\hline AFAF16 & 1,00 & & & 0 & 0,32 \\
\hline AFAF01 & 0,48 & 0,06 & 8,39 & & 0,82 \\
\hline \multicolumn{6}{|c|}{ Proteção } \\
\hline AFAF02 & 0,94 & 0,06 & 17,17 & 0 & 0,31 \\
\hline AFAF14 & 1,01 & 0,05 & 18,89 & 0 & 0,62 \\
\hline AFAF03 & 1,05 & 0,05 & 21,69 & & \\
\hline AFAF13 & 0,75 & 0,05 & 15,33 & & \\
\hline AFAF04 & 1,00 & & & & 0,66 \\
\hline
\end{tabular}

Fonte: Dados da pesquisa

Todas as variáveis inseridas apresentaram significância pois seu p-valor foi abaixo de 0,05, como aponta Marôco (2010), e o critical ratio (C.R.) atendeu ao padrão estabelecido por Byrne (2010) que destaca que este deve ser superior a 1,96. Ademais, foram estabelecidos outros resultados atinentes ao ajuste do modelo, com $X^{2} / G . L=3,26, p<0,000-o$ que indica ajuste aceitável da estrutura. Os índices de ajuste foram considerados bons, com $\mathrm{CFI}=0,95, \mathrm{RMSEA}=0,073(\mathrm{IC} 90 \%=0,065-0,082)$ e $\mathrm{SRMR}=0,053$. Os resultados alcançados confirmam a estrutura dos estudos originais.

Para entendimento das possíveis associações entre as variáveis, torna-se preponderante a realização de análises que permitam a verificação de associação entre os constructos estudados, de predição entre estes e a própria comparação entre os grupos (amostras) estabelecidos nesta pesquisa. 


\subsection{Testes Estatísticos}

Em continuidade às ações pertinentes à pesquisa, foram realizadas as correlações, regressões, a verificação de mediação e o Teste-t de média. A Tabela 17 apresenta as siglas utilizadas nas análises estatísticas e seu respectivo significado para cada constructo estudado.

Tabela 17

Descrição das siglas dos constructos e variáveis utilizadas

\begin{tabular}{|c|c|c|c|}
\hline Constructo/Variável & $\begin{array}{c}\text { Fator de } 2^{a} \\
\text { Ordem } \\
\text { (Sigla) }\end{array}$ & $\begin{array}{c}\text { Fator de } 1^{a} \\
\text { Ordem } \\
\text { (Sigla) }\end{array}$ & Descrição \\
\hline \multicolumn{2}{|c|}{ MEDO DO CRIME } & $\begin{array}{c}\text { AFE } \\
\text { COGN } \\
\text { COMP }\end{array}$ & $\begin{array}{l}\text { Afeto } \\
\text { Cognição } \\
\text { Comportamento }\end{array}$ \\
\hline \multirow{4}{*}{$\begin{array}{l}\text { VALORES } \\
\text { HUMANOS }\end{array}$} & CONSER & $\begin{array}{c}\text { COI } \\
\text { COR } \\
\text { HUM } \\
\text { SEP } \\
\text { SES } \\
\text { TRAD }\end{array}$ & $\begin{array}{l}\text { Conformidade Interpessoal } \\
\text { Conformidade com Regras } \\
\text { Humildade } \\
\text { Segurança Pessoal } \\
\text { Segurança Social } \\
\text { Tradição }\end{array}$ \\
\hline & AUTOTR & $\begin{array}{l}\text { BEC } \\
\text { BED } \\
\text { UNC } \\
\text { UNN } \\
\text { UNT }\end{array}$ & $\begin{array}{l}\text { Benevolência Cuidado } \\
\text { Benevolência Dependência } \\
\text { Universalismo Compromisso } \\
\text { Universalismo Natureza } \\
\text { Universalismo Tolerância }\end{array}$ \\
\hline & AUTOPROM & $\begin{array}{r}\text { FAC } \\
\text { POD } \\
\text { POR } \\
\text { REAL }\end{array}$ & $\begin{array}{l}\text { Face } \\
\text { Poder de Domínio } \\
\text { Poder sobre Recursos } \\
\text { Realização }\end{array}$ \\
\hline & ABERT & $\begin{array}{l}\text { HED } \\
\text { ADA } \\
\text { ADP } \\
\text { EST }\end{array}$ & $\begin{array}{l}\text { Realização } \\
\text { Poder de Domínio } \\
\text { Poder sobre Recursos } \\
\text { Face }\end{array}$ \\
\hline \multicolumn{2}{|c|}{$\begin{array}{c}\text { ATITUDE FRENTE À ARMA DE } \\
\text { FOGO }^{\mathrm{a}}\end{array}$} & $\begin{array}{l}\text { DIRE } \\
\text { CRIM } \\
\text { PROT }\end{array}$ & $\begin{array}{l}\text { Direito } \\
\text { Crime } \\
\text { Proteção }\end{array}$ \\
\hline
\end{tabular}

Fonte: Dados da Pesquisa.

Nota: ${ }^{a}$ Estes constructos representam um fator de $2^{\text {a }}$ ordem também.

\subsubsection{Correlações}

Para verificar a correlação entre valores, medo do crime e atitude frente à arma de fogo Hair et al. (2009) indicam a realização do $r$ de Pearson, como forma de entendimento, ainda que razoavelmente superficial, acerca das relações que existem entre as variáveis. Em 
um primeiro momento, optou-se por efetivar as correlações entre fatores de $1^{\mathrm{a}}$ ordem, ou seja, os três fatores de medo do crime, os 19 fatores (tipos motivacionais) de valores humanos e os três fatores de atitude frente à arma de fogo.

No intuito de facilitar a visualização e o entendimento, optou-se pela realização da verificação segmentada das associações entre as variáveis, iniciando-se por fatores distintos de valores humanos. Neste sentido, foi realizada a correlação entre os três fatores do medo do crime, da atitude frente à arma de fogo e os conjuntos dos tipos motivacionais de valores alocados numa $2^{\mathrm{a}}$ ordem, visto não ser (ao menos nesse momento) a relação entre fatores de primeira e segunda ordem das variáveis do estudo, a ação realizada no momento. Os dados dos fatores foram obtidos pela média aritmética entre as variáveis estabelecidas para cada constructo e a Tabela 18 demonstra os resultados de correlação entre afeto, cognição e comportamento - medo do crime -, os tipos motivacionais integrantes da Conservação e os fatores integrantes da atitude frente à arma de fogo - direitos, crime e proteção - para a amostra da população em geral (amostra 1).

Tabela 18

Correlações entre medo do crime, valores individuais (conservação) e atitude frente à arma de fogo (amostra 1)

\begin{tabular}{|c|c|c|c|c|c|c|c|c|c|c|c|c|}
\hline & AFE & COGN & СОМР & $\mathrm{COI}$ & COR & HUM & SEP & SES & TRAD & DIRE & CRIM & PROT \\
\hline AFE & 1 & & & & & & & & & & & \\
\hline COGN & $0,31^{* *}$ & 1 & & & & & & & & & & \\
\hline COMP & $-0,12^{*}$ & 0,06 & 1 & & & & & & & & & \\
\hline COI & 0,06 & $0,18^{* *}$ & $-0,05$ & 1 & & & & & & & & \\
\hline COR & 0,01 & $0,10^{*}$ & $-0,02$ & $0,61^{* *}$ & 1 & & & & & & & \\
\hline HUM & 0,09 & $0,20^{* *}$ & $-0,04$ & $0,66^{* *}$ & $0,62^{* *}$ & 1 & & & & & & \\
\hline SEP & $-0,04$ & 0,07 & $-0,07$ & $0,58^{* *}$ & $0,61^{* *}$ & $0,59^{* *}$ & 1 & & & & & \\
\hline SES & 0,01 & $0,11^{*}$ & $-0,01$ & $0,56^{* *}$ & $0,61^{* *}$ & $0,64^{* *}$ & $0,61^{* *}$ & 1 & & & & \\
\hline TRAD & 0,02 & 0,09 & $-0,04$ & $0,55^{* *}$ & $0,59^{* *}$ & $0,64^{* *}$ & $0,63^{\text {** }}$ & $0,75^{* *}$ & 1 & & & \\
\hline DIRE & $-0,08$ & 0,04 & $0,21^{* *}$ & 0,06 & $-0,01$ & $-0,05$ & $-0,01$ & $-0,08$ & $-0,10^{*}$ & 1 & & \\
\hline CRIM & 0,06 & $0,10^{*}$ & $-0,15^{* *}$ & $0,25^{* *}$ & $0,24^{* *}$ & $0,25^{* *}$ & $0,23^{* *}$ & $0,24^{* *}$ & $0,26^{* *}$ & $-0,07$ & 1 & \\
\hline PROT & $-0,09$ & 0,00 & $0,22^{* *}$ & 0,05 & $-0,06$ & $-0,14^{* *}$ & $-0,03$ & $-0,14^{* *}$ & $-0,16^{* *}$ & $0,63^{* *}$ & 0,00 & 1 \\
\hline
\end{tabular}

Fonte: Dados da Pesquisa.

Nota: ${ }^{* *}$ representa valores para $p<0,01 \mathrm{e}^{*}$ representa valores para $p<0,05$.

Observa-se uma limitada quantidade de relações entre os fatores do medo do crime e 
os valores humanos de conservação, sendo apresentada tais interações intervariáveis apenas para o fator de cognição (COGN), que apresentou coeficientes significativos com COI $(0,18)$, COR $(0,10)$, HUM $(0,20)$ e SES $(0,11)$, porém pequenos (Field, 2009). Também verificou-se pequena relação entre os fatores de medo do crime e da atitude frente a arma de fogo, aparecendo significância apenas entre COMP e DIRE (0,21), COMP e CRIM (-0,15), COMP e PROT $(0,22)$ e COGN e CRIM $(0,10)$.

As correlações entre os fatores de atitude frente à arma de fogo e os valores de conservação também foram baixos, entretanto verificou-se que o fator crime obteve correlação significativa e mediana com todos os seis valores integrantes do tipo motivacional conservação - COI $(0,25), \operatorname{COR}(0,24), \operatorname{HUM}(0,25), \operatorname{SEP}(0,23), \operatorname{SES}(0,24)$ e TRAD $(0,26)$. Os demais fatores, por seu turno, apresentaram poucas relações e com índices pequenos, como DIRE e TRAD $(-0,10)$, PROT e HUM $(-0,14)$, PROT e SES $(-0,14)$ e PROT e TRAD $(-0,16)$.

As relações intravariáveis apresentaram coeficientes de correlação superiores a 0,50 para os valores de conservação, sugerindo que existe forte relação entre os fatores (Tabachnick \& Fidell, 2007), como nos casos de COI e COR (0,61), COI e HUM $(0,66)$, COI e SEP $(0,58)$, COI e SES $(0,56)$, COI e TRAD $(0,55)$, COR e HUM $(0,62)$, COR e SEP $(0,61)$, COR e SES $(0,61)$, COR e TRAD $(0,59)$, HUM e PROT $(0,59)$, HUM e SES $(0,64)$, HUM e TRAD $(0,64)$, PROT e SES $(0,61)$, PROT e TRAD $(0,63)$ e SES e TRAD $(0,75)$ sendo esta última a mais alta desta análise. Voltando a atenção para o medo do crime, o afeto apresentou relações pequena e moderada com o comportamento $(-0,12)$ e com a cognição $(0,31)$, respectivamente, não tendo sido demonstrada relação entre os dois últimos fatores. A atitude frente à arma de fogo, de modo similar, apresentou forte relação entre direitos e proteção $(0,63)$, não havendo significância nas demais interações.

A Tabela 19 realiza idêntico procedimento correlacional entre os fatores de variáveis 
já destacados, voltando-se à amostra obtida com de estudantes universitários residentes da

Ceilândia (amostra 2).

Tabela 19

Correlações entre medo do crime, valores individuais (conservação) e atitude frente à arma de fogo (amostra 2)

\begin{tabular}{|c|c|c|c|c|c|c|c|c|c|c|c|c|}
\hline & AFE & COGN & СОМР & COI & COR & HUM & SEP & SES & TRAD & DIRE & CRIM & PROT \\
\hline AFE & 1 & & & & & & & & & & & \\
\hline COGN & $0,47^{* *}$ & 1 & & & & & & & & & & \\
\hline СОМР & $0,64^{* *}$ & $0,42^{* *}$ & 1 & & & & & & & & & \\
\hline COI & 0,07 & 0,05 & 0,09 & 1 & & & & & & & & \\
\hline COR & $-0,01$ & $0,10^{*}$ & 0,03 & $0,43^{* *}$ & 1 & & & & & & & \\
\hline HUM & 0,09 & 0,08 & $0,10^{*}$ & $0,50^{* *}$ & $0,49^{* *}$ & 1 & & & & & & \\
\hline SEP & $0,15^{* *}$ & $0,19^{* *}$ & $0,17^{* *}$ & $0,47^{* *}$ & $0,61^{* *}$ & $0,54^{* *}$ & 1 & & & & & \\
\hline SES & $0,12^{*}$ & $0,19^{* *}$ & $0,14^{* *}$ & $0,41^{* *}$ & $0,63^{* *}$ & $0,47^{* *}$ & $0,67^{* *}$ & 1 & & & & \\
\hline TRAD & 0,02 & 0,06 & $-0,03$ & $0,43^{* *}$ & $0,56^{* *}$ & $0,45^{* *}$ & $0,41^{* *}$ & $0,35^{* *}$ & 1 & & & \\
\hline DIRE & $-0,04$ & $-0,09$ & $-0,15^{* *}$ & 0,05 & 0,00 & 0,04 & $-0,03$ & $-0,031$ & 0,05 & 1 & & \\
\hline CRIM & 0,06 & $0,12^{*}$ & 0,091 & $0,13^{* *}$ & $0,12^{*}$ & $0,12^{*}$ & $0,16^{* *}$ & $0,14^{* *}$ & $0,11^{*}$ & $-0,33^{* *}$ & 1 & \\
\hline PROT & $-0,031$ & $-0,08$ & $-0,14^{* *}$ & 0,02 & $-0,02$ & 0,02 & $-0,05$ & $-0,07$ & 0,05 & $0,76^{* *}$ & $-0,17^{* *}$ & 1 \\
\hline
\end{tabular}

Fonte: Dados da Pesquisa.

Nota: ${ }^{* *}$ representa valores para $p<0,01 \mathrm{e}^{*}$ representa valores para $p<0,05$.

Observa-se pequena relação entre os fatores do medo do crime e os valores humanos de conservação, sendo maior a correlação entre cognição e a segurança pessoal $(0,19)$ e entre aquela e a segurança social $(0,19)$. Também verificou-se pequena correlação entre os fatores de medo do crime e da atitude frente a arma de fogo, aparecendo significância apenas entre comportamento e direitos $(-0,15)$, comportamento e proteção $(-0,14)$ e cognição e crime $(0,12)$.

As correlações entre os fatores de atitude frente à arma de fogo e os valores de conservação também foram baixos; entretanto, verificou-se que o fator crime obteve correlação significativa (ainda que pequena) com todos os seis valores integrantes do tipo motivacional conservação $(0,13 ; 0,12 ; 0,12 ; 0,16 ; 0,14 ; 0,11)$. Os demais fatores, por seu turno, não apresentaram correlações com os valores humanos do destacado tipo motivacional.

As correlações intravariáveis apresentaram coeficientes de correlação superiores ou próximos a 0,50, sugerindo que existe forte relação entre os fatores (Tabachnick \& Fidell, 
2007), como nos casos de AFE e COGN $(0,47)$, AFE e COMP $(0,64)$, COGN e COMP $(0,42)$; para os valores humanos de conservação destacou-se a conformidade com as regras (COR), nas relações com humildade $(0,49)$, com segurança pessoal $(0,61)$, com segurança social $(0,63)$ e com tradição $(0,56)$, chamando a atenção ainda alta correlação entre os fatores de segurança (privada e pessoal; 0,67); a atitude frente à arma de fogo apresentou relações moderadas entre os fatores, DIR e CRIM $(-0,33)$ e CRIM e PROT $(-0,17)$, apresentando, por outro lado, a maior correlação desta tabela entre DIR e PROT $(0,76)$.

Em continuidade, a Tabela 20 expõe os resultados de correlação dos fatores de medo do crime, os tipos motivacionais integrantes da Autotranscendência e os fatores integrantes da atitude frente à arma de fogo para a amostra da população em geral (amostra 1).

Tabela 20

Correlações entre medo do crime, valores individuais (autotranscendência) e atitude frente à arma de fogo (amostra 1)

\begin{tabular}{|c|c|c|c|c|c|c|c|c|c|c|c|}
\hline & AFE & COGN & СОМР & BEC & BED & UNC & UNN & UNT & DIRE & CRIM & PROT \\
\hline AFE & 1 & & & & & & & & & & \\
\hline COGN & $0,31^{* *}$ & 1 & & & & & & & & & \\
\hline СОМР & $-0,12^{*}$ & 0,06 & 1 & & & & & & & & \\
\hline BEC & 0,02 & 0,03 & $-0,08$ & 1 & & & & & & & \\
\hline BED & 0,02 & $0,10^{*}$ & $-0,03$ & $0,75^{* *}$ & 1 & & & & & & \\
\hline UNC & 0,00 & 0,07 & $-0,02$ & $0,76^{* *}$ & $0,69^{* *}$ & 1 & & & & & \\
\hline UNN & 0,04 & $0,18^{* *}$ & 0,00 & $0,55^{* *}$ & $0,57^{* *}$ & $0,62^{* *}$ & 1 & & & & \\
\hline UNT & 0,07 & $0,11^{*}$ & $-0,04$ & $0,69^{* *}$ & $0,69^{* *}$ & $0,73^{* *}$ & $0,60^{* *}$ & 1 & & & \\
\hline DIRE & $-0,08$ & 0,04 & $0,21^{* *}$ & $-0,09$ & $-0,05$ & $-0,11^{*}$ & $-0,02$ & $-0,07$ & 1 & & \\
\hline CRIM & 0,06 & $0,10^{*}$ & $-0,15^{* *}$ & $0,23^{* *}$ & $0,22^{* *}$ & $0,25^{* *}$ & $0,19^{* *}$ & $0,28^{* *}$ & $-0,07$ & 1 & \\
\hline PROT & $-0,09$ & 0,00 & $0,22^{* *}$ & $-0,14^{* *}$ & $-0,07$ & $-0,15^{* *}$ & $-0,05$ & $-0,14^{* *}$ & $0,63^{* *}$ & 0,00 & 1 \\
\hline
\end{tabular}

Fonte: Dados da Pesquisa.

Nota: ${ }^{* *}$ representa valores para $p<0,01 \mathrm{e}^{*}$ representa valores para $p<0,05$.

Os resultados da tabela demonstram uma limitada quantidade de interações significativas entre os fatores do medo do crime e os valores humanos de autotranscendência, com resultados apenas para o fator cognição, sendo eles COGN e UNN $(0,18)$, COGN e UNT $(0,11)$ e COGN e $\operatorname{BED}(0,10)$. No que tange à relação entre valores e atitude frente à arma de fogo, de modo semelhante aos resultados dos valores de conservação, destacaram-se as 
conexões com o fator crime, que apresentou significância nas relações de todos os fatores de valores - com $\operatorname{BEC}(0,23)$, com $\operatorname{BED}(0,22)$, com $\operatorname{UNC}(0,25)$, com UNN $(0,19)$ e com UNT (0,28; a maior delas) - de baixa a mediana força.

As relações intravariáveis dos valores de autotranscendência apresentaram coeficientes de correlação fortes, majoritariamente superiores a 0,60 , com destaque para as interações de $\operatorname{BEC}$ e UNC $(0,76)$, BEC e $\operatorname{BED}(0,75)$ e UNT e UNC $(0,73)$. Estabelecendo progressão, a Tabela 21 demonstra os resultados de correlação dos fatores de medo do crime, os tipos motivacionais integrantes da autotranscendência e os fatores integrantes da atitude frente à arma de fogo para a amostra de estudantes universitários (amostra 2).

Tabela 21

Correlações entre medo do crime, valores individuais (autotranscendência) e atitude frente à arma de fogo (amostra 2)

\begin{tabular}{|c|c|c|c|c|c|c|c|c|c|c|c|}
\hline & AFE & COGN & СОМР & BEC & BED & UNC & UNN & UNT & DIRE & CRIM & PROT \\
\hline AFE & 1 & & & & & & & & & & \\
\hline COGN & $0,49^{* *}$ & 1 & & & & & & & & & \\
\hline COMP & $0,64^{* *}$ & $0,42^{* *}$ & 1 & & & & & & & & \\
\hline BEC & 0,08 & $0,16^{* *}$ & $0,13^{* *}$ & 1 & & & & & & & \\
\hline BED & 0,03 & $0,13^{*}$ & $0,11^{*}$ & $0,73^{* *}$ & 1 & & & & & & \\
\hline UNC & 0,06 & $0,12^{*}$ & $0,13^{* *}$ & $0,75^{* *}$ & $0,69^{* *}$ & 1 & & & & & \\
\hline UNN & 0,08 & 0,07 & 0,10 & $0,48^{* *}$ & $0,45^{* *}$ & $0,46^{* *}$ & 1 & & & & \\
\hline UNT & $0,10^{*}$ & $0,13^{* *}$ & $0,16^{* *}$ & $0,63^{* *}$ & $0,53^{* *}$ & $0,65^{* *}$ & $0,40^{* *}$ & 1 & & & \\
\hline DIRE & $-0,04$ & $-0,09$ & $-0,15^{* *}$ & $-0,10$ & $-0,07$ & $-0,12^{*}$ & 0,01 & $-0,08$ & 1 & & \\
\hline CRIM & 0,06 & $0,12^{*}$ & 0,09 & $0,21^{* *}$ & $0,17^{* *}$ & $0,21^{* *}$ & $0,19^{* *}$ & $0,17^{* *}$ & $-0,33^{* *}$ & 1 & \\
\hline PROT & $-0,03$ & $-0,08$ & $-0,14^{* *}$ & $-0,15^{* *}$ & $-0,08$ & $-0,15^{* *}$ & 0,02 & $-0,09$ & $0,76^{* *}$ & $-0,17^{* *}$ & 1 \\
\hline
\end{tabular}

Fonte: Dados da Pesquisa.

Nota: ${ }^{* *}$ representa valores para $p<0,01 \mathrm{e}^{*}$ representa valores para $p<0,05$.

Os resultados da tabela demonstram uma maior quantidade de interações significativas entre os fatores do medo do crime e os valores humanos de autotranscendência, em comparação aos valores de conservação para a amostra estabelecida, com resultados apenas para os três fatores, destacando-se os fatores cognitivo e comportamental, que apresentaram índices significativos, porém com baixa força, particularmente nas relações COGN e BEC $(0,16)$, COMP e UNT $(0,16)$, COGN e BED $(0,13)$, COMP e BEC e COMP e 
UNC (ambas com 0,13$)$ e AFE e UNT $(0,10)$.

No que diz respeito à relação entre valores e atitude frente à arma de fogo, de modo semelhante aos resultados dos valores de conservação, destacaram-se as conexões com o fator crime, que apresentou significância nas relações de todos os fatores de valores - com $\operatorname{BEC}(0,21)$, com $\operatorname{BED}(0,17)$, com $\operatorname{UNC}(0,21)$, com $\operatorname{UNN}(0,19)$ e com UNT $(0,17)-$ de baixa a mediana força.

As relações intravariáveis dos valores de autotranscendência apresentaram coeficientes de correlação fortes, com índices superiores a 0,50, com destaque para as interações de BEC e UNC $(0,75)$ e de BEC e BED $(0,73)$. Caminhando um pouco mais, a Tabela 22 reflete os resultados de correlação dos fatores de medo do crime, os tipos motivacionais integrantes da autopromoção e os fatores integrantes da atitude frente à arma de fogo para a amostra da população em geral (amostra 1).

Tabela 22

Correlações entre medo do crime, valores individuais (autopromoção) e atitude frente à arma de fogo (amostra 1)

\begin{tabular}{|c|c|c|c|c|c|c|c|c|c|c|}
\hline & AFE & COGN & СОМР & FAC & POD & POR & REAL & DIRE & CRIM & PROT \\
\hline AFE & 1 & & & & & & & & & \\
\hline COGN & $0,31^{* *}$ & 1 & & & & & & & & \\
\hline СОМР & $-0,12^{*}$ & 0,06 & 1 & & & & & & & \\
\hline FAC & 0,01 & 0,06 & $-0,01$ & 1 & & & & & & \\
\hline POD & $-0,03$ & $0,15^{* *}$ & 0,04 & $0,40^{* *}$ & 1 & & & & & \\
\hline POR & $-0,01$ & $0,15^{* *}$ & 0,04 & $0,32^{* *}$ & $0,72^{* *}$ & 1 & & & & \\
\hline REAL & $-0,02$ & $0,12^{*}$ & 0,04 & $0,55^{* *}$ & $0,55^{* *}$ & $0,58^{* *}$ & 1 & & & \\
\hline DIRE & $-0,08$ & 0,04 & $0,21^{* *}$ & $-0,05$ & $0,12^{*}$ & $0,13^{*}$ & 0,07 & 1 & & \\
\hline CRIM & 0,06 & $0,10^{*}$ & $-0,15^{* *}$ & $0,16^{* *}$ & $0,12^{*}$ & $0,17^{* *}$ & $0,19^{* *}$ & $-0,07$ & 1 & \\
\hline PROT & $-0,09$ & 0,00 & $0,22^{* *}$ & $-0,05$ & $0,19^{* *}$ & $0,22^{* *}$ & 0,06 & $0,63^{\text {** }}$ & 0,00 & 1 \\
\hline
\end{tabular}

Fonte: Dados da Pesquisa.

Nota: ${ }^{* *}$ representa valores para $p<0,01 \mathrm{e}^{*}$ representa valores para $p<0,05$.

A Tabela 22, em semelhança às tabelas 18 e 20, destaca as relações de apenas um dos fatores do medo do crime e os valores humanos de autopromoção, cognição, com relações significativas em COGN e FAC $(0,15)$, em COGN e POD $(0,15)$ e em COGN e REAL $(0,12)$. 
No que tange à relação entre valores e atitude frente à arma de fogo, os três fatores apresentaram relações, de fracas a medianas, com destaque para PROT e POR $(0,22)$, PROT e POD $(0,19)$ e CRIM e REAL $(0,19)$.

As relações internas das variáveis dos valores de autotranscendência apresentaram coeficientes de correlação fortes, em sua maioria superiores a 0,50 , com destaque para a mediana relação entre FAC e POR $(0,32)$ e para a forte relação POD e POR $(0,72)$.

Ato contínuo, a Tabela 23 demonstra os resultados de correlação dos fatores de medo do crime, os tipos motivacionais integrantes da autopromoção e os fatores integrantes da atitude frente à arma de fogo para a amostra de estudantes universitários (amostra 2).

Tabela 23

Correlações entre medo do crime, valores individuais (autopromoção) e atitude frente à arma de fogo (amostra 2)

\begin{tabular}{|c|c|c|c|c|c|c|c|c|c|c|}
\hline & AFE & COGN & COMP & FAC & POD & POR & REAL & DIRE & CRIM & PROT \\
\hline AFE & 1 & & & & & & & & & \\
\hline COGN & $0,49^{* *}$ & 1 & & & & & & & & \\
\hline СОМР & $0,64^{* *}$ & $0,42^{* *}$ & 1 & & & & & & & \\
\hline FAC & 0,07 & 0,07 & 0,08 & 1 & & & & & & \\
\hline POD & $-0,02$ & $-0,04$ & $-0,07$ & $0,43^{* *}$ & 1 & & & & & \\
\hline POR & $-0,01$ & $-0,03$ & 0,01 & $0,35^{* *}$ & $0,57^{* *}$ & 1 & & & & \\
\hline REAL & 0,01 & 0,03 & 0,02 & $0,48^{* *}$ & $0,45^{* *}$ & $0,54^{* *}$ & 1 & & & \\
\hline DIRE & $-0,04$ & $-0,09$ & $-0,15^{* *}$ & 0,04 & $0,18^{* *}$ & $0,30^{* *}$ & $0,14^{* *}$ & 1 & & \\
\hline CRIM & 0,06 & $0,12^{*}$ & 0,09 & $0,12^{*}$ & $-0,01$ & $-0,07$ & $-0,03$ & $-0,33^{* *}$ & 1 & \\
\hline PROT & $-0,03$ & $-0,08$ & $-0,14^{* *}$ & 0,06 & $0,21^{* *}$ & $0,34^{* *}$ & $0,14^{* *}$ & $0,76^{* *}$ & $-0,17^{* *}$ & 1 \\
\hline
\end{tabular}

Fonte: Dados da Pesquisa.

Nota: ${ }^{* *}$ representa valores para $p<0,01 \mathrm{e}^{*}$ representa valores para $p<0,05$.

A Tabela 23 demonstra resultados que não alcançaram relações significativas entre os fatores do medo do crime e os valores de autopromoção, e na relação entre estes e a atitude frente à arma de fogo, os três fatores apresentaram relações, de fracas a medianas, com destaque para os fatores de proteção - com as relações PROT e POR $(0,34)$, PROT e POD $(0,21)$ e PROT e REAL $(0,14)$ - e direitos - com DIRE e POR $(0,30)$, DIRE e POD $(0,18)$ e DIRE e REAL $(0,14)$.

As relações internas das variáveis dos valores de autopromoção apresentaram 
coeficientes de correlação fortes, em sua maioria próximos a 0,50 , com destaque para a forte relação entre $\operatorname{POD}$ e $\operatorname{POR}(0,57)$ e para a relação $\operatorname{POR}$ e $\operatorname{REAL}(0,54)$.

Alcançado o último tipo motivacional de $2^{\mathrm{a}}$ ordem, a Tabela 24 apresenta os resultados de correlação dos fatores de medo do crime, os tipos motivacionais integrantes da abertura à mudança e os fatores integrantes da atitude frente à arma de fogo para a amostra da população em geral (amostra 1).

Tabela 24

Correlações entre medo do crime, valores individuais (abertura à mudança) e atitude frente à arma de fogo (amostra 1)

\begin{tabular}{|c|c|c|c|c|c|c|c|c|c|c|}
\hline & AFE & COGN & COMP & HED & ADA & ADP & EST & PROT & DIRE & CRIM \\
\hline AFE & 1 & & & & & & & & & \\
\hline COGN & $0,305^{* *}$ & 1 & & & & & & & & \\
\hline COMP & $-0,12^{*}$ & 0,06 & 1 & & & & & & & \\
\hline HED & $-0,06$ & 0,06 & $-0,03$ & 1 & & & & & & \\
\hline ADA & $-0,01$ & 0,08 & 0,00 & $0,63^{* *}$ & 1 & & & & & \\
\hline ADP & 0,04 & $0,10^{*}$ & $-0,03$ & $0,60^{* *}$ & $0,71^{* *}$ & 1 & & & & \\
\hline EST & $-0,02$ & $0,13^{* *}$ & 0,04 & $0,66^{* *}$ & $0,50^{* *}$ & $0,56^{* *}$ & 1 & & & \\
\hline PROT & $-0,09$ & 0,00 & $0,22^{* *}$ & 0,00 & $-0,09$ & $-0,10^{*}$ & 0,05 & 1 & & \\
\hline DIRE & $-0,08$ & 0,04 & $0,21^{* *}$ & 0,01 & $-0,01$ & $-0,06$ & 0,06 & $0,63^{* *}$ & 1 & \\
\hline CRIM & 0,06 & $0,10^{*}$ & $-0,15^{* *}$ & $0,17^{* *}$ & $0,20^{* *}$ & $0,19^{* *}$ & $0,15^{* *}$ & 0,00 & $-0,07$ & 1 \\
\hline
\end{tabular}

Fonte: Dados da Pesquisa.

Nota: ${ }^{* *}$ representa valores para $p<0,01 \mathrm{e}^{*}$ representa valores para $p<0,05$.

A Tabela 24, como nos três resultados anteriores para a amostra da população em geral, destaca as relações de apenas um dos fatores do medo do crime e os valores humanos de abertura à mudança, cognição, com relações significativas em COGN e EST $(0,13)$ e em COGN e $\operatorname{ADP}(0,10)$. No que tange à relação entre valores e atitude frente à arma de fogo, proeminência para o fator crime, com significativas relações com todos os valores da tabela $\operatorname{ADA}(0,20), \operatorname{ADP}(0,19), \operatorname{HED}(0,17)$ e $\operatorname{EST}(0,15)$.

As relações internas das variáveis dos valores de abertura à mudança apresentaram coeficientes de correlação fortes, majoritariamente superiores a 0,60 , com realce para a forte relação entre FAC e POR $(0,32)$ e para a relação POD e POR $(0,72)$. 
Finalmente, a Tabela 25 elenca os resultados de correlação dos fatores de medo do crime, os tipos motivacionais integrantes da abertura à mudança e os fatores integrantes da atitude frente à arma de fogo para a amostra de estudantes universitários (amostra 2).

Tabela 25

Correlações entre medo do crime, valores individuais (abertura à mudança) e atitude frente à arma de fogo (amostra 2)

\begin{tabular}{|c|c|c|c|c|c|c|c|c|c|c|}
\hline & AFE & COGN & СОМР & HED & ADA & ADP & EST & PROT & DIRE & CRIM \\
\hline AFE & 1 & & & & & & & & & \\
\hline COGN & $0,49^{* *}$ & 1 & & & & & & & & \\
\hline COMP & $0,64^{* *}$ & $0,42^{* *}$ & 1 & & & & & & & \\
\hline HED & 0,04 & $0,11^{*}$ & 0,07 & 1 & & & & & & \\
\hline ADA & 0,03 & $0,11^{*}$ & $0,11^{*}$ & $0,63^{* *}$ & 1 & & & & & \\
\hline ADP & 0,04 & $0,13^{* *}$ & $0,14^{* *}$ & $0,62^{* *}$ & $0,76^{* *}$ & 1 & & & & \\
\hline EST & 0,04 & 0,05 & 0,08 & $0,61^{* *}$ & $0,54^{* *}$ & $0,49^{* *}$ & 1 & & & \\
\hline PROT & $-0,04$ & $-0,09$ & $-0,15^{* *}$ & 0,08 & $-0,04$ & $-0,02$ & 0,06 & 1 & & \\
\hline DIRE & 0,06 & $0,12^{*}$ & 0,09 & 0,08 & $0,14^{* *}$ & 0,07 & $0,11^{*}$ & $-0,33^{* *}$ & 1 & \\
\hline CRIM & $-0,03$ & $-0,08$ & $-0,14^{* *}$ & 0,08 & $-0,08$ & $-0,06$ & $0,10^{*}$ & $0,76^{* *}$ & $-0,17^{* *}$ & 1 \\
\hline
\end{tabular}

Fonte: Dados da Pesquisa.

Nota: ${ }^{* *}$ representa valores para $p<0,01 \mathrm{e}^{*}$ representa valores para $p<0,05$.

Na Tabela 25 foi possível verificar a existência de relação entre os fatores cognição e comportamento do medo do crime e os valores humanos de abertura à mudança, com relações significativas em COMP e $\operatorname{ADP}(0,14), \operatorname{COGN}$ e $\operatorname{ADP}(0,13), \operatorname{COMP}$ e $\operatorname{ADA}(0,11)$, COGN e $\operatorname{ADA}(0,11)$ e em COGN e $\operatorname{HED}(0,11)$. No que se refere à interação entre valores e atitude frente à arma de fogo, foram demonstradas relações com os direito - DIRE e ADA $(0,14)$ e entre DIRE e EST $(0,11)$ - e uma relação com crime - CRIM e EST $(0,10)$.

As relações internas das variáveis dos valores de abertura à mudança apresentaram coeficientes de correlação fortes, quase todos superiores a 0,60 , com realce para a forte relação entre $\operatorname{ADP}$ e $\operatorname{ADA}(0,76)$ e para a relação $\operatorname{ADA}$ e $\operatorname{HED}(0,63)$.

Estabelecidas as relações entre os fatores de $1^{\mathrm{a}}$ ordem, torna-se interessante verificar como se comportariam as relações entre fatores de $1^{\mathrm{a}}$ e $2^{\mathrm{a}}$ ordem de duas variáveis (medo do crime e atitude frente à arma de fogo) e os fatores de $2^{\mathrm{a}}$ ordem dos valores humanos individuais, apresentados nas Tabela 26 (amostra 1) e Tabela 27 (amostra 2). 
Tabela 26

Correlações entre medo do crime, valores individuais e atitude frente à arma de fogo (fatores de $1^{a}$ e $2^{a}$ ordem, amostra 1)

\begin{tabular}{|c|c|c|c|c|c|c|c|c|c|c|c|c|}
\hline & AFE & COGN & СОМР & MC & CONSER & $\begin{array}{c}\text { AUTO } \\
\text { TR } \\
\end{array}$ & $\begin{array}{l}\text { AUTO } \\
\text { PROM } \\
\end{array}$ & ABERT & DIRE & CRIM & PROT & AFAF \\
\hline AFE & 1 & & & & & & & & & & & \\
\hline COGN & $0,31^{* *}$ & 1 & & & & & & & & & & \\
\hline COMP & $-0,12^{*}$ & 0,06 & 1 & & & & & & & & & \\
\hline MC & $0,81^{* *}$ & $0,61^{* *}$ & $0,40^{* * *}$ & 1 & & & & & & & & \\
\hline CONSER & 0,03 & $0,15^{* *}$ & $-0,05$ & 0,06 & 1 & & & & & & & \\
\hline $\begin{array}{c}\text { AUTO } \\
\text { TR }\end{array}$ & 0,03 & $0,12^{*}$ & $-0,04$ & 0,05 & $0,89^{* *}$ & 1 & & & & & & \\
\hline $\begin{array}{l}\text { AUTO } \\
\text { PROM } \\
\end{array}$ & $-0,02$ & $0,15^{* *}$ & 0,04 & 0,06 & $0,65^{* *}$ & $0,56^{* *}$ & 1 & & & & & \\
\hline ABERT & $-0,02$ & $0,11^{*}$ & $-0,01$ & 0,02 & $0,78^{* *}$ & $0,80^{* *}$ & $0,73^{* *}$ & 1 & & & & \\
\hline DIRE & $-0,08$ & 0,04 & $0,21^{* *}$ & 0,05 & $-0,03$ & $-0,08$ & 0,09 & 0,00 & 1 & & & \\
\hline CRIM & 0,06 & $0,10^{*}$ & $-0,15^{* *}$ & 0,01 & $0,30^{* *}$ & $0,27^{* *}$ & $0,20^{* *}$ & $0,21^{* *}$ & $-0,07$ & 1 & & \\
\hline PROT & $-0,09$ & 0,00 & $0,22^{* *}$ & 0,03 & $-0,09$ & $-0,13^{*}$ & $0,15^{* *}$ & $-0,04$ & $0,63^{* *}$ & $-0,00$ & 1 & \\
\hline AFAF & $-0,06$ & 0,07 & $0,14^{* *}$ & 0,04 & 0,08 & 0,03 & $0,22^{* *}$ & 0,09 & $0,78^{* *}$ &, $44^{* *}$ &, $81^{* *}$ & 1 \\
\hline
\end{tabular}

Fonte: Dados da Pesquisa

Nota: $\quad{ }^{* *}$ representa valores para $p<0,01 \mathrm{e}^{*}$ representa valores para $p<0,05$.

- MC representa o medo do crime e AFAF atitude frente à arma de fogo.

Tabela 27

Correlações entre medo do crime, valores individuais e atitude frente à arma de fogo (fatores de $1^{a}$ e $2^{a}$ ordem, amostra 2)

\begin{tabular}{|c|c|c|c|c|c|c|c|c|c|c|c|c|}
\hline & AFE & COGN & СОМР & MC & CONSER & $\begin{array}{c}\text { AUTO } \\
\text { TR }\end{array}$ & $\begin{array}{l}\text { AUTO } \\
\text { PROM }\end{array}$ & ABERT & DIRE & CRIM & PROT & AFAF \\
\hline AFE & 1 & & & & & & & & & & & \\
\hline COGN & $0,49^{* *}$ & 1 & & & & & & & & & & \\
\hline COMP & $0,64^{* *}$ & $0,42^{* *}$ & 1 & & & & & & & & & \\
\hline MC & $0,88^{* *}$ & $0,70^{* *}$ & $0,87^{* *}$ & 1 & & & & & & & & \\
\hline $\begin{array}{c}\text { CONSE } \\
\mathbf{R}\end{array}$ & 0,09 & $0,14^{* *}$ & $0,10^{*}$ & $0,13^{* *}$ & 1 & & & & & & & \\
\hline $\begin{array}{c}\text { AUTO } \\
\text { TR }\end{array}$ & 0,09 & $0,15^{* *}$ & $0,15^{* *}$ & $0,15^{* *}$ & $0,83^{* *}$ & 1 & & & & & & \\
\hline $\begin{array}{l}\text { AUTO } \\
\text { PROM }\end{array}$ & 0,02 & 0,01 & 0,01 & 0,02 & $0,54^{* *}$ & $0,46^{* *}$ & 1 & & & & & \\
\hline ABERT & 0,04 & $0,12^{*}$ & $0,12^{*}$ & $0,11^{*}$ & $0,68^{* *}$ & $0,80^{* *}$ & $0,57^{* *}$ & 1 & & & & \\
\hline DIRE & $-0,04$ & $-0,09$ & $-0,15^{* *}$ & $-0,11^{*}$ & 0,02 & $-0,08$ & $0,22^{* *}$ & 0,02 & 1 & & & \\
\hline CRIM & 0,06 & $0,12^{*}$ & 0,09 & $0,10^{*}$ & $0,17^{* *}$ & $0,23^{* *}$ & 0,00 & $0,12^{*}$ & $-0,33^{* *}$ & 1 & & \\
\hline PROT & $-0,03$ & $-0,08$ & $-0,14^{* *}$ & $-0,10^{*}$ & $-0,01$ & $-0,11^{*}$ & $0,25^{* *}$ & 0,01 & $0,76^{* *}$ & $-0,17^{* *}$ & 1 & \\
\hline AFAF & $-0,01$ & $-0,03$ & $-0,11^{*}$ & $-0,06$ & $0,10^{*}$ & 0,02 & $0,25^{* *}$ & 0,08 & $0,77^{* *}$ & $0,26^{* *}$ & $0,85^{* *}$ & 1 \\
\hline
\end{tabular}

Fonte: Dados da Pesquisa

Nota: $\quad{ }^{* *}$ representa valores para $p<0,01 \mathrm{e}^{*}$ representa valores para $p<0,05$.

- MC representa o medo do crime e AFAF atitude frente à arma de fogo.

$\mathrm{Na}$ Tabela 26 (amostra da população em geral), os fatores de $1^{\mathrm{a}}$ e $2^{\mathrm{a}}$ ordem do medo do crime não apresentaram relações significativas com os tipos motivacionais de $2^{\mathrm{a}}$ ordem 
dos valores humanos, à exceção do fator cognição, que apresentou relações significativas (porém fracas) com os quatro fatores de $2^{\mathrm{a}}$ ordem - COGN e CONSER $(0,15)$, COGN e AUtotr $(0,12)$, COGN e AUtOprom $(0,15)$ e COGN e ABERT $(0,11)$. Por outro lado, com os fatores de $1^{\mathrm{a}}$ e $2^{\mathrm{a}}$ ordem de atitude frente à arma de fogo foram notadas relações significativas por meio do fator comportamento - COMP e DIRE $(0,21)$, COMP e CRIM (0,15), COMP e PROT $(0,22)$ e $\operatorname{COMP}$ e $\operatorname{AFAF}(0,14)$ - e de uma relação do fator cognição com o fator crime $(0,10)$, não sendo verificada relação entre o componente afetivo e entre o fator de $2^{\mathrm{a}}$ ordem medo do crime com quaisquer dos fatores das outras variáveis.

A atitude frente à arma de fogo, por meios de seus fatores de $1^{\mathrm{a}}$ e $2^{\mathrm{a}}$ ordem, só não apresentou significância nas interações do fator direitos, ressaltando-se os resultados significativos do fator crime nas associações com todos os tipos motivacionais de valores CRIM e CONSERV $(0,30)$, CRIM e AUTOTR $(0,27)$, CRIM e AUTOPROM $(0,20)$ e CRIM e $\operatorname{ABERT}(0,21)$ - e a interação significativa entre $\operatorname{AFAF}$ e $\operatorname{AUTOPROM}(0,22)$.

$\mathrm{Na}$ Tabela 27 (amostra de estudantes universitários), por seu turno, os fatores de $1^{\mathrm{a}} \mathrm{e}$ $2^{\mathrm{a}}$ ordem do medo do crime apresentaram relações significativas com os tipos motivacionais de conservação, autotranscendência e abertura à mudanças, não alcançando o mesmo resultado para autopromoção - destacando as relações entre COGN, COMP e MC com AUTOPROM (0,15 para estas interações). O componente afetivo do medo do crime não alcançou relação significativa com nenhum tipo motivacional.

Noutro panorama, a interação entre o medo do crime com os fatores de $1^{\mathrm{a}}$ e $2^{\mathrm{a}}$ ordem de atitude frente à arma de fogo foram notadas relações significativas por meio do fator comportamento - COMP e DIRE $(0,15)$, COMP e PROT $(-0,14)$ e COMP e AFAF $(-0,11)-$, do fator medo do crime - MC e DIRE $(-0,11)$, MC e PROT $(-0,10), \operatorname{MC}$ e CRIM $(0,10)-\mathrm{e}$ do fator cognição - COGN e CRIM $(0,12)$.

A atitude frente à arma de fogo, por meios de seus fatores de $1^{\mathrm{a}}$ e $2^{\mathrm{a}}$ ordem, só não 
apresentou significância nas interações do fator direitos, ressaltando-se os resultados significativos do fator crime nas associações com todos os tipos motivacionais de valores CRIM e CONSERV $(0,30)$, CRIM e AUTOTR $(0,27)$, CRIM e AUTOPROM $(0,20)$ e CRIM e $\operatorname{ABERT}(0,21)$ - e a interação significativa entre $\operatorname{AFAF}$ e $\operatorname{AUTOPROM}(0,22)$.

Estabelecidos os relacionamentos entre as variáveis, torna-se imprescindível a realização de regressões para o teste da capacidade de predição da dinâmica dos constructos.

\subsubsection{Regressĩes}

1) Variáveis estabelecidas no estudo

Com o objetivo de testar a capacidade de predizer o medo do crime e a atitude frente à arma de fogo, foram realizadas regressões lineares múltiplas, utilizando os Valores Humanos Individuais para as amostras estabelecidas na pesquisa (população em geral e estudantes universitários). Foram realizadas regressões lineares múltiplas também para testar se a atitude frente à arma de fogo era capaz de predizer a variável medo do crime.

Os coeficientes de determinação $\left(\mathrm{R}^{2}\right)$, ou seja a proporção da variabilidade total que é explicada pela regressão, de maneira geral, tende a aumentar quando itens e variáveis independentes são incluídos no modelo (Marôco, 2011). Entretanto, como destaca Healy (1984), é possível entender melhor o resultado, e evitar aumentos probabilísticos não reais, ao utilizar-se o $\mathrm{R}^{2}$ ajustado, pois este pode servir como melhor estimador do modelo, por levar em consideração o aumento do $\mathrm{R}^{2}$ se, e somente se, a nova variável acrescida repercutir em aumento do ajuste do modelo, ou seja, somente se a variância dos erros diminuir em relação à variância total explicada (Marôco, 2011). Neste sentido, optou-se pela utilização do $\mathrm{R}^{2}$ ajustado.

Para a amostra da população em geral (amostra 1) e considerando os Valores Humanos como variáveis independentes, não há relação significativa entre estes e o Afeto, 
foi estabelecido um $\mathrm{R}^{2}$ ajustado de 0,04 para a variável dependente Cognição e não há correlação entre aqueles e o Comportamento. O medo do Crime ( $2^{\mathrm{a}}$ ordem), como variável dependente, não apresenta índice de correlação significativo com os tipos motivacionais de $2^{\mathrm{a}}$ ordem dos Valores Humanos.

Estabelecidos novamente os valores humanos como variáveis independentes e, deste vez, os fatores da atitude frente à arma de fogo como variáveis dependentes, estabeleceu-se um $\mathrm{R}^{2}$ ajustado de 0,01 para o fator Direito, um $\mathrm{R}^{2}$ ajustado de 0,08 para o fator Crime e um $\mathrm{R}^{2}$ ajustado de 0,05 para o fator Proteção. O fator de $2^{\mathrm{a}}$ ordem AFAF (atitude frente à arma de fogo) enquanto variável dependente em associação aos tipos motivacionais de $2^{\mathrm{a}}$ ordem dos valores humanos, como variáveis independentes, expressaram um $\mathrm{R}^{2}$ ajustado de 0,04 .

Desta vez dispostos os fatores de atitude frente à arma de fogo como variáveis independentes, foram definidos os fatores integrantes do medo do crime como variáveis dependentes, não havendo relação significativa entre aqueles e o fator Afeto, sendo alcançado um $\mathrm{R}^{2}$ ajustado de 0,01 para o fator Cognição e um $\mathrm{R}^{2}$ ajustado de 0,05 para o fator Comportamento. Os fatores de $2^{\mathrm{a}}$ ordem atitude frente à arma de fogo e medo do crime não apresentaram índices de associação significativos.

Tabela 28

Regressões realizadas para a amostra 1

\begin{tabular}{ccccccc}
\hline Variável Independente & Variável Dependente & $\mathbf{R}$ & $\mathbf{R}^{\mathbf{2}}$ & $\begin{array}{c}\mathbf{R}^{\mathbf{2}} \\
\text { Ajustado }\end{array}$ & Sig. & Teste Estatístico \\
\hline Valores Humanos & Afeto & - & - & - & - & - \\
Valores Humanos & Cognição & 0,20 & 0,04 & 0,04 & 0,00 & $\mathrm{~F}=16,49$ \\
Valores Humanos & Comportamento & - & - & - & - & - \\
Valores Humanos & Medo do Crime & - & - & - & - & - \\
Valores Humanos & Direito & 0,13 & 0,02 & 0,01 & 0,00 & $\mathrm{~F}=6,66$ \\
Valores Humanos & Crime & 0,28 & 0,08 & 0,08 & 0,00 & $\mathrm{~F}=34,33$ \\
Valores Humanos & Proteção & 0,22 & 0,05 & 0,05 & 0,00 & $\mathrm{~F}=20,46$ \\
Valores Humanos & AFAF & 0,22 & 0,05 & 0,04 & 0,00 & $\mathrm{~F}=20,00$ \\
AFAF & Afeto & - & - & - & - & - \\
AFAF & Cognição & 0,10 & 0,01 & 0,01 & 0,04 & $\mathrm{~F}=4,17$
\end{tabular}




\begin{tabular}{ccccccc} 
AFAF & Comportamento & 0,22 & 0,05 & 0,05 & 0,00 & $\mathrm{~F}=20,34$ \\
AFAF $^{\mathrm{c}}$ & Medo do Crime $^{\mathrm{a}}$ & - & - & - & - & - \\
\hline
\end{tabular}

Fonte: Dados da Pesquisa

Notas: ${ }^{a}$ tipos motivacionais de $2^{\mathrm{a}}$ ordem do constructo.

${ }^{\mathrm{b}}$ fator de $3^{\mathrm{a}}$ ordem do constructo.

${ }^{\mathrm{c}}$ fator de $2^{\mathrm{a}}$ ordem do constructo.

Para a amostra de estudantes e considerando os Valores Humanos como variáveis independentes, foi obtido um $\mathrm{R}^{2}$ ajustado de 0,02 para a variável dependente Afeto, um $\mathrm{R}^{2}$ de 0,03 para Cognição e um $\mathrm{R}^{2}$ ajustado de 0,03 para Comportamento. Quando adotada a variável dependente Medo do Crime ( $2^{\mathrm{a}}$ ordem), e considerando os tipos motivacionais de $2^{\mathrm{a}}$ ordem dos Valores Humanos como variáveis independentes, obtém-se um $\mathrm{R}^{2}$ ajustado de 0,02 .

Ainda utilizando os valores humanos como variáveis independentes e os fatores da atitude frente à arma de fogo como variáveis dependentes, estabeleceu-se um $\mathrm{R}^{2}$ ajustado de 0,09 para o fator Direito, um $\mathrm{R}^{2}$ ajustado de 0,04 para o fator Crime e um $\mathrm{R}^{2}$ ajustado de 0,11 para o fator Proteção. $\mathrm{O}$ fator de $2^{\mathrm{a}}$ ordem $\mathrm{AFAF}$, quando predita pelos tipos motivacionais de $2^{\mathrm{a}}$ ordem dos valores humanos, apresenta um $\mathrm{R}^{2}$ ajustado de 0,06 .

Voltando a atenção para a relação entre atitude frente à arma de fogo (variável independente) e o medo do crime (variável dependente), não há relação significativa entre os fatores daquela e o fator Afeto, resultou em um $\mathrm{R}^{2}$ ajustado de 0,01 para o fator Cognição e obteve-se um $\mathrm{R}^{2}$ ajustado de 0,02 para o fator Comportamento. Com relação à predição do medo do crime pela atitude frente à arma de fogo, não há índices de correlação significativos entre as variáveis. 
Tabela 29

Regressões realizadas para a amostra 2

\begin{tabular}{ccccccc}
\hline Variável Dependente & Variáveis Independentes & $\mathbf{R}$ & $\mathbf{R}^{\mathbf{2}}$ & $\begin{array}{c}\mathbf{R}^{\mathbf{2}} \\
\text { Ajustado }\end{array}$ & Sig. & Teste Estatístico \\
\hline Valores Humanos & Afeto & 0,15 & 0,02 & 0,02 & 0,00 & $\mathrm{~F}=9,80$ \\
Valores Humanos & Cognição & 0,19 & 0,04 & 0,03 & 0,00 & $\mathrm{~F}=15,68$ \\
Valores Humanos & Comportamento & 0,17 & 0,03 & 0,03 & 0,00 & $\mathrm{~F}=12,41$ \\
Valores Humanos & Medo do Crime & 1,15 & 0,02 & 0,02 & 0,00 & $\mathrm{~F}=9,931$ \\
Valores Humanos & Direito & 0,30 & 0,09 & 0,09 & 0,00 & $\mathrm{~F}=41,03$ \\
Valores Humanos & Crime & 0,21 & 0,05 & 0,04 & 0,00 & $\mathrm{~F}=19,73$ \\
Valores Humanos & Proteção & 0,34 & 0,12 & 0,11 & 0,00 & $\mathrm{~F}=54,57$ \\
Valores Humanos & AFAF & 0,25 & 0,06 & 0,06 & 0,00 & $\mathrm{~F}=27,56$ \\
AFAF & Afeto & - & - & - & - & - \\
AFAF & Cognição & 0,12 & 0,01 & 0,01 & 0,01 & $\mathrm{~F}=6,05$ \\
AFAF & Comportamento & 0,15 & 0,02 & 0,02 & 0,00 & $\mathrm{~F}=9,17$ \\
AFAF & Medo do Crime & - & - & - & - & - \\
\hline
\end{tabular}

Fonte: Dados da Pesquisa.

Notas: ${ }^{a}$ tipos motivacionais de $2^{\mathrm{a}}$ ordem do constructo.

${ }^{\mathrm{b}}$ fator de $3^{\mathrm{a}}$ ordem do constructo.

${ }^{\mathrm{c}}$ fator de $2^{\mathrm{a}}$ ordem do constructo.

A escolha pela regressões pelo método stepwise teve por objetivo a determinação com parcimônia da influência dos Valores Humanos nas variáveis dependentes, em convergência com o sugerido por Paschoal e Tamayo (2005), que lembram da necessidade de um modelo mais parcimonioso em estudos exploratórios, caso da regressão stepwise, capaz de testar quais variáveis são responsáveis por maiores percentuais de colaboração em maiores variâncias da variável dependente.

Ainda que não esteja constituído como objetivo da pesquisa, por apresentar natureza exploratória, torna-se interessante verificar alguns dados sociodemográficos apontados na doutrina como preditores de medo do crime, tais como sexo, idade, entre outros (Jackson, 2009).

2) Variáveis sociodemográficas

Como já dito anteriormente, um conjunto diversificado de pesquisas têm sido dedicadas à hipótese de vulnerabilidade, que estipula que fatores sociodemográficos como 
idade, sexo, etnia e deficiência física são preditores de medo do crime, uma vez que pessoas pertencentes a esses grupos sociais se sentem fisicamente ou socialmente vulneráveis (Rader, Cossman, \& Porter, 2012) e, portanto, com um maior risco de vitimização (ver Pain, 2000). Outros enfatizaram o papel da experiência de vitimização (direta e indireta) como fator importante no desenvolvimento do medo do crime (ver Lane, Rader, Henson, Fischer, \& May, 2014).

Para verificar a capacidade de predição das variáveis sociodemográficas, foram selecionadas as variáveis sexo (SEX), idade (ID), escolaridade (ESC), classe socioeconômica comparada (CEC) e a vitimização (VIT) - se a pessoa já foi vítima de algum crime nos últimos doze meses - para a realização da regressão por stepwise, em ambas as amostras. Neste sentido, foi possível verificar que a variável sexo (SEX) representa o melhor modelo de capacidade de predição entre as cinco variáveis sociodemográficas, chegando aos seguintes resultados $(\boldsymbol{\beta}=2,4 ; \mathrm{p}<0,001)$ :

- com a amostra 1 (população em geral): $\mathrm{R}^{2}$ ajustado de 0,10 para o fator Afeto; $\mathrm{R}^{2}$ ajustado de 0,02 para o fator Cognição; $\mathrm{R}^{2}$ ajustado de 0,05 para o fator Comportamento; $\mathrm{R}^{2}$ ajustado de 3\% para o constructo Medo do Crime;

- com a amostra 2 (estudantes universitários): $\mathrm{R}^{2}$ ajustado de 0,04 para o fator Afeto; $\mathrm{R}^{2}$ ajustado de 0,02 para o fator Cognição; $\mathrm{R}^{2}$ ajustado de 0,18 para o fator Comportamento; $\mathrm{R}^{2}$ ajustado de $11 \%$ para o constructo Medo do Crime. 
Tabela 30

Regressões realizadas para variáveis sociodemográficas

\begin{tabular}{cccccccc}
\hline Amostra & $\begin{array}{c}\text { Variáveis } \\
\text { Independentes }\end{array}$ & $\begin{array}{c}\text { Variável } \\
\text { Dependente }\end{array}$ & $\mathbf{R}$ & $\mathbf{R}^{\mathbf{2}}$ & $\begin{array}{c}\mathbf{R}^{\mathbf{2}} \\
\text { Ajustado }\end{array}$ & $\begin{array}{c}\text { Sig. } \\
\text { Estatístico }\end{array}$ \\
\hline Amostra 1 & Sociodemográficas & Afeto & 0,31 & 0,10 & 0,10 & 0 & $\mathrm{~F}=44,82$ \\
Amostra 1 & Sociodemográficas & Cognição & 0,14 & 0,02 & 0,02 & 0,01 & $\mathrm{~F}=7,70$ \\
Amostra 1 & Sociodemográficas & Comportamento & 0,23 & 0,05 & 0,05 & 0 & $\mathrm{~F}=23,45$ \\
Amostra 1 & Sociodemográficas & Medo do Crime ${ }^{\mathrm{a}}$ & 0,18 & 0,03 & 0,03 & 0 & $\mathrm{~F}=13,10$ \\
Amostra 2 & Sociodemográficas & Afeto & 0,20 & 0,04 & 0,04 & 0 & $\mathrm{~F}=17,93$ \\
Amostra 2 & Sociodemográficas & Cognição & 0,15 & 0,02 & 0,02 & 0 & $\mathrm{~F}=9,315$ \\
Amostra 2 & Sociodemográficas & Comportamento & 0,43 & 0,18 & 0,18 & 0 & $\mathrm{~F}=94,05$ \\
Amostra 2 & Sociodemográficas & Medo do Crime & 0,33 & 0,11 & 0,11 & 0 & $\mathrm{~F}=51,79$ \\
\hline
\end{tabular}

Fonte: Dados da Pesquisa.

Nota: ${ }^{\text {a }}$ Fator de $2^{\text {a }}$ ordem do constructo.

Os resultados com relação à sexo apontaram também que as mulheres apresentaram maiores níveis de medo do crime em comparação aos homens, para ambas as amostras apresentadas, sendo necessária a confirmação deste entendimento através de teste de médias (que será realizada no próximo tópico).

Concluídas as regressões para estabelecer a relação das escalas de Valores Humanos, de Atitude Frente à Arma de Fogo, e variáveis sociodemográficas com o medo do crime, será realizada a comparação de médias, no intuito de entender se há diferença para as variâncias iguais assumidas, não sendo possível a realização do teste de moderação para a atitude frente à arma de fogo, visto não ter sido significativa a capacidade de predição desta variável ante ao medo do crime, em nenhuma das amostras.

\subsubsection{Teste de médias}

No intuito de verificar se há diferença nos índices do medo do crime, nas amostras coletadas, foram seguidas as recomendações de Hair et al. (2009) que indica que o teste de igualdade de médias para comparação de dois grupos é o teste-t, que no caso desta pesquisa, confrontou as diferenças de médias entre a população em geral residente da Ceilândia e os estudantes universitários de uma instituição localizada na citada RA, também residentes da 
localidade. O resultado apresentou diferença não significativa entre as amostras coletadas, indicando que o medo do crime é percebido de maneira similar entre os indivíduos, independentemente das diferenças amostrais verificadas, ainda que existam diferenças significativas nas médias das amostras para os fatores integrantes do constructo.

Os resultados podem ser observados na Tabela 31.

\section{Tabela 31}

Testes-T para o Medo do Crime comparando amostras da população em geral e de estudantes universitários, todos residentes da Ceilândia

\begin{tabular}{|c|c|c|c|c|c|c|c|}
\hline Variável & Amostra & $\mathrm{N}$ & Média & $\begin{array}{l}\text { Desvio- } \\
\text { Padrão }\end{array}$ & GL & $\mathrm{t}$ & Sig. \\
\hline \multirow{2}{*}{ Afeto } & População & 414 & 2,92 & 0,62 & \multirow{2}{*}{832} & \multirow{2}{*}{3,44} & \multirow{2}{*}{0,00} \\
\hline & Estudantes & 420 & 2,65 & 0,60 & & & \\
\hline \multirow{2}{*}{ Cognição } & População & 414 & 3,58 & 0,96 & \multirow{2}{*}{832} & \multirow{2}{*}{11,76} & \multirow{2}{*}{0,00} \\
\hline & Estudantes & 420 & 3,01 & 1,15 & & & \\
\hline \multirow{2}{*}{ Comportamento } & População & 414 & 1,95 & 0,65 & \multirow{2}{*}{832} & \multirow{2}{*}{$-15,09$} & \multirow{2}{*}{0,00} \\
\hline & Estudantes & 420 & 2,87 & 0,70 & & & \\
\hline \multirow{2}{*}{ Medo do Crime } & População & 414 & 2,82 & 0,62 & \multirow{2}{*}{832} & \multirow{2}{*}{$-1,04$} & \multirow{2}{*}{0,31} \\
\hline & Estudantes & 420 & 2,86 & 0,60 & & & \\
\hline
\end{tabular}

Fonte: Dados da pesquisa.

Complementando o achado do tópico anterior, em relação à capacidade de predição entre as variáveis sociodemográficas e o medo do crime, verificou-se como preditor único desta relação, para ambas amostras coletadas, o sexo. Diante disso, realizou-se um teste-t para verificar a existência de diferença de médias entre homens e mulheres com relação ao medo do crime, conforme Tabela 32.

Tabela 32

Testes-T para o Medo do Crime comparando amostras de sexo

\begin{tabular}{|c|c|c|c|c|c|c|c|}
\hline Variável & Amostra & $\mathrm{N}$ & Média & $\begin{array}{c}\text { Desvio- } \\
\text { Padrão }\end{array}$ & GL & $\mathrm{t}$ & Sig. \\
\hline \multirow{2}{*}{ Afeto } & Homens & 376 & 2,46 & 0,96 & \multirow{2}{*}{832} & \multirow{2}{*}{$-7,87$} & \multirow{2}{*}{0,31} \\
\hline & Mulheres & 458 & 3,05 & 1,15 & & & \\
\hline \multirow{2}{*}{ Cognição } & Homens & 376 & 3,21 & 0,65 & \multirow{2}{*}{832} & \multirow{2}{*}{$-4,23$} & \multirow{2}{*}{0,31} \\
\hline & Mulheres & 458 & 3,41 & 0,70 & & & \\
\hline \multirow{2}{*}{ Comportamento } & Homens & 376 & 2,29 & 0,75 & \multirow{2}{*}{832} & \multirow{2}{*}{$-3,24$} & \multirow{2}{*}{0,31} \\
\hline & Mulheres & 458 & 2,51 & 1,13 & & & \\
\hline \multirow{2}{*}{ Medo do Crime } & Homens & 376 & 2,65 & 0,52 & \multirow{2}{*}{832} & \multirow{2}{*}{$-8,21$} & \multirow{2}{*}{0,31} \\
\hline & Mulheres & 458 & 2,99 & 0,64 & & & \\
\hline
\end{tabular}

Fonte: Dados da pesquisa. 
Foram encontradas diferenças significativas nas médias entre homens e mulheres de ambas as amostras com relação ao medo do crime, e também aos seus fatores, reforçando os achados obtidos pela regressão pelo método stepwise.

A seguir, serão discutidos os resultados obtidos nessa pesquisa, com a aplicação teórica dos aspectos que envolvem o trabalho e entendimento mais pormenorizado dos resultados. 


\section{Capítulo 5}

\section{Discussão}

Este capítulo tem por finalidade analisar e interpretar os resultados encontrados. Para tanto, os achados serão comparados à literatura indicada e os objetivos de pesquisa. Assim, primeiro serão apresentados os dados referentes ao levantamento de evidências de validade da Escala de Medo do Crime para, em seguida, proceder à discussão dos resultados das análises exploratórias e confirmatórias, de correlações, regressões passo a passo e testes de médias, comparando os dados coletados com a população em geral (amostra 1) e com os estudantes universitários residentes na Ceilândia.

O referencial teórico demonstrou que uma das principais preocupações e desafios dos pesquisadores que trabalham com o constructo medo do crime é estabelecer um modelo teórico mais concreto e padronizado, que permita constante testagem com utilização de parâmetros similares, no intuito de estabelecer bases mais consolidadas para o entendimento da variável. Neste sentido, ao realizar-se a análise fatorial exploratória, foi pré-estabelecido um modelo tripartite de medo do crime - com as dimensões afeto, cognição e comportamento - para validação da análise confirmatória dos fatores (Gabriel \& Greve, 2003; Jackson, 2015). O modelo estabelecido após a análise exploratória apresentou três fatores: Afeto com seis itens (MC02, MC04, MC05, MC07, MC08 e MC09), Cognição com quatro itens, (MC13, MC15, MC16 e MC17) e Comportamento com três itens (MC01, MC06 e MC12).

Dando continuidade à pesquisa, foi realizada a análise confirmatória dos três constructos, sendo iniciada pela Escala do Medo do Crime (com a amostra de estudantes). Os índices de ajuste da escala foram considerados bons, indicando a estrutura confirmatória dos fatores. A partir dos índices de modificação expostos por Marôco (2011), que apontam a redução conservadora do $\mathrm{X}^{2}$ do modelo se um parâmetro fixo ou uma igualdade de 
parâmetros for liberado, se erros de medida forem correlacionados depois da reestimação do modelo, foram descartados os itens MC05 e MC09 do modelo. O fator Afeto passa a ter, diante disso, um número total de quatro itens. Foram realizadas também as análises confirmatórias de Valores Humanos Individuais e Atitude Frente à Arma de Fogo, tendo os resultados alcançados confirmado a estrutura dos estudos originais.

Em busca do alcance dos objetivos geral e específicos, foram realizadas correlações entre os três constructos, separados por amostras e por tipos motivacionais de segunda ordem dos valores. Assim, foram apresentados quatro resultados correlacionais para cada amostra, além da correlação final envolvendo os fatores de $1^{\mathrm{a}}$ e $2^{\mathrm{a}}$ ordens dos constructos. Para a amostra 1 (população em geral), constatou-se uma consistência interna não ideal do medo do crime, posto que dois dos fatores do medo do crime não se relacionavam com significância. Este fato também foi constatado com a atitude frente à arma de fogo, que na amostra só conseguiu estabelecer uma das correlações possíveis entre seus fatores internos. Os Valores Humanos Individuais, por outro lado, apresentaram correlações consistentes entre todos os tipos motivacionais de $1^{\mathrm{a}}$ ordem, em ambas as amostras, reforçando o ajuste e a robustez do modelo. Na amostra 2 (alunos universitários), por outro lado, tanto o medo do crime quanto a atitude frente a arma de fogo apresentaram relações significativas entre os seus próprios fatores, reforçando o entendimento de que a estrutura do modelo do medo do crime está estabelecida, mas pode e deve ser consolidada com maior ênfase no futuro, através da aplicação de novas pesquisas, só para citar um exemplo

Para que seja possível estabelecer um panorama mais entendível, foram verificadas diferenças importantes nas interações entre as escalas: na amostra 1, o fator cognição se relacionou significativamente com 11 valores, enquanto afeto e comportamento não apresentaram uma única relação significativa com os 19 . Na amostra 2, de outro modo, cognição apresentou interação significativa com 12 dos 19 valores, ficando afeto com 4 
interações e comportamento com 5. O afeto apresentou uma ausência quase total das interações com os valores, o que talvez possa ser explicado pelo fato de algumas indicarem que o componente cognitivo sobrepuja os demais componentes. Mackenzie (1986), por exemplo, propôs que as respostas cognitivas - como a cognição e o conhecimento dos indivíduos sobre os objetos - influenciaram principalmente as percepções e as atitudes em relação às propagandas (mediadas) em relação às respostas afetivas e comportamentais. A pesquisa de marketing de destino apoiou que as dimensões cognitivas, tais como a maximização de uma oferta de informações sobre os pontos fortes e serviços do destino, foram avaliadas como um componente importante para fomentar a visitação em um destino (Pike e Ryan, 2004).

Esta prevalência do aspecto cognitivo sobre os demais no medo do crime também pode ser explicado pela utilização de pesquisas internacionais para a elaboração dos itens, pesquisas estas que utilizam tanto a teoria bipartite (afeto e comportamento) como a teoria tripartite do medo do crime (afeto, cognição e comportamento), o que torna alguns constructos possivelmente inadequados para a mensuração de determinados aspectos, o que significa dizer, de maneira mais clara, que itens cognitivos podem estar eivados de afeto, ou vice-versa, ou ainda os itens comportamentais (que também apresentaram limitadíssimas quantidades de relações significativas com os valores) possam estar baseados em aspectos cognitivo-comportamentais, reforçando então a força relacional de apenas um dos fatores.

Ademais, não custa lembrar que ao serem testados os mesmos itens em uma amostra populacional específica (estudantes universitários, no caso da amostra 2), o entendimento dos itens tende a ser um pouco diferente, tanto que Schwartz e Butenko (2014) alertaram para a necessidade de captação de amostras de países menos desenvolvidos, integrada por indivíduos com características diferentes dos países ocidentais desenvolvidos, com níveis de escolaridade mais baixos, o que pode talvez possa ter sido refletido no comportamento das 
relações entre as variáveis. Tanto que na amostra 2 foram verificadas relações significativas entre os componentes afetivo e comportamental do medo do crime com os valores humanos.

Este comportamento entre as variáveis foi refletido na tabelas 26 e 27 , onde claramente pode-se notar o comportamento entre os fatores de $2^{\mathrm{a}}$ ordem: enquanto na amostra 1 o medo do crime não alcançou relações significativas com nenhum dos quatro tipos motivacionais de $2^{\mathrm{a}}$ ordem dos valores humanos, na amostra 2 foram verificadas relações significativas (ainda que com índices baixos) entre medo do crime e os fatores de conservação, autotranscendência e abertura à mudança. Este contexto se repetiu com atitude frente à arma de fogo, visto que o medo do crime não apresentou significância com as relações entre os fatores desta atitude, tampouco com a própria atitude na amostra 1, enquanto na amostra 2 foram verificadas relações significativas entre o medo do crime e os fatores de direitos, crime e proteção, não sendo tal significância encontrada entre o medo do crime e a atitude frente à arma de fogo.

Tratando do sentido das relações, o medo do crime apresentou relações significativas com os tipos motivacionais de conservação, autotranscendência e abertura à mudança, as duas primeiras positivas e a última negativa, o que significa dizer que as alterações em uma das variáveis altera a outra em um mesmo sentido (não significando, entretanto, que a mudança em uma variável causa a mudança em outra, como estabelece Field, 2009). A existência de relação entre medo do crime e valores pode ser entendida, no caso da autotranscendência como a preocupação não só com a própria segurança, como também com a segurança do endogrupo (benevolência cuidado) e com a segurança da sociedade (universalismo compromisso), características próprias de países mais coletivistas (termo que deve ser usado com cautela, em vista da necessidade de comparação com outro país para assumir-se tal premissa), como é o caso do Brasil (Hofstede, 1980). Tanto que a regressão stepwise entre medo do crime e os tipos motivacionais de $2^{\mathrm{a}}$ ordem estabeleceu como o 
preditor mais forte nesta relação a autotranscendência, justificando também a ausência de significância na relação do medo do crime com autopromoção.

Voltando o foco para as relações entre medo do crime e os tipos motivacionais conservação e abertura à mudança, os resultados refletiram o que se espera na teoria, ou seja, que as relações entre medo do crime e estes tipos motivacionais de $2^{\mathrm{a}}$ ordem sejam contrários. Desta maneira, conservação representada por valores de conformidade com as regras, humildade, segurança pessoal e segurança social, apresenta ligação positiva com o medo do crime, significando que maiores níveis de um repercutem em maiores níveis do outro.

Por outro lado, a relação entre medo do crime e abertura à mudança foi significativa e negativa, significando dizer que quanto maior o medo do crime, maior a abertura à mudança (em uma relação não causal). Tal contexto se explica pelos valores integrantes deste tipo motivacional - hedonismo, autodireção (pensamento e ação) e estimulação - os quais demonstram que as respostas ao medo do crime, ou a expectativa destas respostas, apresentam caráter de opções mais coletivistas - os indivíduos tendem a se organizar em coletividades, como associações de bairros, conselhos de segurança, entre outros - e voltados aos valores próprios do tipo motivacional de conservação (tais como segurança).

$\mathrm{Na}$ relação entre o medo do crime e a atitude frente à arma de fogo, mesmo não encontrando resultados significativos em nenhuma das amostras entre as variáveis, foram verificadas na amostra 2 associações significativas entre medo do crime e os três fatores da atitude frente à arma de fogo, direitos, crime e proteção, sendo a relação positiva com os dois primeiros e negativa com o terceiro. Estas relações estabelecem bastante sentido com a teoria proposta (Branscombe et al., 1991; Nascimento et al., 2016), visto que o fator Direitos liga-se à visualização da posse de armas como um direito fundamental do indivíduo, ou seja, a relação entre aumento do medo do crime e aumento do entendimento da posse de arma como 
um direito, fazem todo o sentido. O interessante deste fator Direito é a verificação dele em indivíduos brasileiros, em vista da restrição legal do acesso ao porte de armas de fogo, o que não impede a discussão frequente e constante acerca da viabilidade de acesso maior dos brasileiros à arma de fogo, o que pode estar conduzindo os indivíduos a um posicionamento pró armamentista (no sentido de posse a porte pelos indivíduos), em vista da ineficiência estatal no controle dos índices criminais (Silva \& Beato Filho, 2013).

Voltando a atenção ao fator Crime, trata-se da ligação entre armas de fogo e o aumento da criminalidade, tornando a relação positiva entre este e o medo do crime teoricamente inteligível, visto que maiores níveis do medo do crime também demonstram maiores níveis do entendimento de que armas de fogo e crime apresentam ligação próxima (ou o sentido contrário). A relação significativa e negativa entre medo do crime e proteção (arma de fogo como proteção do indivíduo contra a vitimização) corrobora com o entendimento tratado há pouco sobre a restrição de acesso à arma de fogo por parte dos brasileiros: assim, maiores níveis de medo do crime ligam-se a menores níveis de proteção, ou seja, o indivíduo não enxerga a arma de fogo como um meio de proteção contra a vitimização.

Com relação à interação entre atitude frente à arma de fogo e os tipos motivacionais dos valores humanos, obteve-se significância apenas entre o primeiro constructo e o tipo de autopromoção (amostras 1 e 2) e entre aquele e conservação (amostra 2). O sentido das relações demonstra que a atitude frente à arma de fogo é maior com menores índices de conservação, resultado que encontra lógica em vista da já citada restrição ao acesso à arma de fogo, o que a torna sinônimo de contextos negativos (crimes, acidentes com morte, entre outros). Já a atitude frente à arma de fogo e a autopromoção em um sentido positivo, também guardam sentido em vista dos valores de poder (de domínio e sobre os recursos) estarem integrados ao tipo motivacional destacado. 
Voltando a atenção às predições estabelecidas entre o medo do crime, atitude frente à arma de fogo e os valores humanos, como já poderia se esperar em vista dos resultados obtidos com as correlações, constatou-se para a amostra 1 a predição dos valores em relação à atitude frente a arma de fogo $\left(\mathrm{R}^{2}\right.$ ajustado de 0,04$)$, não tendo sido encontradas predições entre valores e medo do crime ou entre atitude frente à arma de fogo e medo do crime. $\mathrm{Na}$ amostra 2, por outro lado, foram obtidos resultados de predição entre valores humanos e medo do crime $\left(\mathrm{R}^{2}\right.$ ajustado de 0,02$)$, entre valores e atitude frente à arma de fogo $\left(\mathrm{R}^{2}\right.$ ajustado de 0,06), não tendo sido encontrado, entretanto, predição entre atitude frente à arma de fogo e medo do crime.

Estes achados impossibilitaram a realização do teste de mediação para os resultados de ambas as amostras, visto que são necessários o cumprimento de três premissas para a verificação da existência de mediação (Field, 2014): (i) índices de regressão entre a variável preditora (valores humanos) e a variável resultado (medo do crime), requisito cumprido na amostra 2; (ii) índices de regressão entre a variável preditora (valore humanos) e a variável mediadora (atitude frente à arma de fogo), requisito cumprido em ambas as amostras; e (iii) índices de regressão entre a variável mediadora (atitude frente à arma de fogo) e a variável resultado (medo do crime), requisito este não alcançado com os dados.

Diversas pesquisas apontam, ainda, a existência de relações importantes entre medo do crime e sexo, idade, experiência de vitimização, entre outros aspectos considerados sociodemográficos (Rader, Cossman, \& Porter, 2012; Jackson, 2014), possibilitando a verificação da capacidade de predição destes em relação ao medo crime. Foram alcançados resultados de predição para ambas as amostras $\left(\mathrm{R}^{2}\right.$ ajustado de 0,03 para a amostra $1 ; \mathrm{R}^{2}$ ajustado de 0,11 para a amostra 2), e o sexo representou o melhor modelo de capacidade de predição entre as cinco variáveis sociodemográficas $(\boldsymbol{\beta}=2,4 ; \mathrm{p}<0,001)$, demonstrando que 
mulheres apresentam maiores níveis de medo do crime, em comparação aos homens, o que foi demonstrado pela comparação de médias entre homens e mulheres da amostra.

Por fim, verificou-se a existência de diferença entre as médias das amostras coletadas (população em geral e estudantes universitários) para o medo do crime, obtendo-se diferença significativa entre as médias de afeto, cognição e comportamento, tendência que não se confirmou para o medo do crime, visto o resultado não significativo obtido. Tal achado refuta a existência de diferença acerca do medo do crime para a população residente da Ceilândia, independentemente de características específicas das amostras coletadas.

Os achados permitiram o alcance dos objetivos específicos propostos no estudo, como também a possibilidade de novos estudos envolvendo as variáveis apresentadas nesta dissertação, como outras, no intuito de estabelecimento de melhor compreensão dos fenômenos psicológicos complexos que envolvem os indivíduos e as organizações sociais por eles estabelecidas. 


\section{Considerações Finais}

O principal objetivo do trabalho foi compreender e descrever como os Valores Individuais e a atitude frente à arma de fogo influenciam o medo do crime na Região Administrativa de Ceilândia, no Distrito Federal, pois a literatura indica que a concentração de estudos em amostras com determinadas características específicas (relacionadas a países ocidentais, desenvolvidos, ao nível de escolaridade dos indivíduos, entre outros) pode estabelecer vieses de resultados e inferências, comprometendo os posicionamentos teóricos existentes.

Para cumprir o objetivo do trabalho, foi realizada uma pesquisa na região administrativa da Ceilândia, no Distrito Federal, onde foram coletados dados referentes aos Valores Humanos, Atitude Frente à Arma de Fogo e Medo do Crime. Os resultados indicaram que os Valores Humanos se relacionam com a atitude frente à arma de fogo, e a relação com o medo do crime só foi alcançada em uma das amostras. Nessa amostra, de estudantes universitários, não foi observada predição de atitude frente à arma de fogo e o medo do crime, refutando a possibilidade de associação entre as três variáveis por meio da mediação. Os resultados indicaram também não haver diferença entre a percepção de medo do crime entre a amostra da população geral e a dos estudantes universitários, ainda que tenha sido verificada diferença significativa entre as médias dos fatores integrantes do medo do crime (afeto, cognição e comportamento).

Um resultado secundário obtido diz respeito à verificação da predição de medo do crime por variáveis sociodemográficas, havendo predominância do sexo nesta relação, o que foi confirmado posteriormente pela comparação das médias. Assim, observou-se que mulheres apresentaram níveis significativamente maiores de medo do que os homens, conforme a literatura da área estabelece. 
Como limitações para esse estudo, indica-se a obtenção das amostras por conveniência, ainda que tenha havido a preocupação de coletar dados de localidades diferentes da região administrativa de Ceilândia, que apresentou uma maior variabilidade. A amostra dos estudantes universitários foi obtida somente em uma instituição de ensino superior localizada na própria Ceilândia. Outra limitação com relação ao estudo foi exatamente a obtenção de dados somente na região de Ceilândia, sendo interessante a verificação das diferenças entre as regiões administrativas, inclusive culturais, para a obtenção de respostas mais específicas dos fenômenos psicológicos.

Outro limitação observada foi a construção da Escala de Medo do Crime por meio de instrumentos internacionais relacionados à temática, o que pode ter repercutido em falta de sincronismo entre os itens da pesquisa e o entendimento dos respondentes. Por fim, também são considerados fatores limitadores da pesquisa as variáveis psicológicas utilizadas, particularmente o medo do crime, pela própria construção teórica necessária para o constructo; a inclusão de outras variáveis atitudinais, normas sociais, entre outras, poderiam aumentar a capacidade de predição das relações testadas.

Recomenda-se como agenda de pesquisa o estabelecimento de uma construção qualitativa de novos itens para o instrumento, no intuito de verificar que itens poderiam ser retirados, novos itens que poderiam ser adicionados à pesquisa, como também, o estabelecimento de itens mais robustos, de acordo com a teoria escolhida pelo pesquisador. Ademais, sugere-se uma coleta em diversas regiões administrativas do DF, buscando maior variabilidade na amostra, bem como realizar a coleta em outros estados para apontar como a relação entre os Valores Humanos e o Medo do Crime ocorre em diferentes contextos. Indica-se também incluir outras variáveis mediadoras e moderadoras da relação entre Valores Humanos e Medo do Crime, como normas sociais e atitudes, além da inclusão de variáveis 
comportamentais em modelos a serem propostos, no intuito de possibilitar o melhor esclarecimento da relação entre os Valores Humanos e o Medo do Crime, podendo reproduzir relações mais precisas e úteis para a população e os órgãos públicos que lidam com a temática. 


\section{Referências}

Abdullah, A., Marzbali, M. H., Bahauddin, A., \& Tilaki, M. J. M. (2015). Broken windows and collective efficacy: Do they affect fear of crime? SAGE Open, 5(1), 1-11.

Acierno, R., Rheingold, A. A., Resnick, H. S., \& Kilpatrick, D. G. (2004). Predictors of fear of crime in older adults. Journal of Anxiety Disorders, 18(3), 385-396.

Adorno, T. W., Frenkel-Brunswik, E., Levinson, D. J., \& Sanford, R. N. (1950). The authoritarian personality. New York: Harper and Row.

Agnew, R. (1985). A revised strain theory of delinquency. Social Forces, 64(1), 151-167.

Ajzen, I., \& Fishbein, M. (2000). Attitudes and the attitude-behavior relation: Reasoned and automatic processes. European Review of Social Psychology, 11, 1-33.

Akers, R. L., LaGreca, A., Sellers, C., \& Cochrane, J. (1987). Fear of crime and victimisation among the elderly in different types of communities. Criminology, 25(3), 487-506.

Allen, M. W. (2000). The attribute-mediation and product meaning approaches to the influences of human values on consumer choices. In F. Columbus (Org.), Advances in Psychology Research (vol.1, pp. 33-76). Huntington, NY: Nova Science Publishers.

Allport, G. W. (1935). Attitudes. In C. Murchison (Org.), The handbook of social psychology (pp. 798-844). Worcester: Clark University Press.

Allport, G. W. (1955). Becoming: Basic considerations for a psychology of personality. New Haven: Yale University Press.

Allport, G. W. (1961). Pattern and growth in personality. New York: Holt, Rinehart \& Winston, Inc.

Altemeyer, B. (1996). The authoritarian specter. Cambridge: Harvard University Press.

Anderson, C. A., Benjamin Jr., A. J., Wood, P. K., \& Bonacci, A. M. (2006). Development and testing of the attitudes toward violence scale: Evidence for a four-factor model. Aggressive Behavior, 32, 122-136.

Aniyar de Castro, L. (1983). Criminologia da reação social. Rio de Janeiro: Forense.

Aquino, K. (2000). Structural and individual determinants of workplace victimization: The effects of hierarchical status and conflict management style. Journal of Management, 26(2), 171-193.

Aquino, K., \& Bradfield, M. (2000). Perceived victimization in the workplace: The role of situational factors and victim characteristics. Organization Science, 11(5), 525-537.

Aristóteles. (350 a. C./2001). Ética a Nicômaco (4⿳a ed., M. Gama, trad.). Brasília: UnB. 
Arnett, J. (2008) The neglected 95\%: Why American psychology needs to become less American. American Psychologist, 63(7), 602-614.

Arnold, H. (1991). Fear of crime and its relationship to directly and indirectly experienced victimisation: A binational comparison of models. In K. Sessar \& H. J. Kerner (Eds.), Developments in Crime and Crime Control Research (pp. 87-125). New York: SpringerVerlag.

Balkin, S. (1979). Victimization rates, safety and fear of crime. Social Problems, 26(3), 343358.

Bandura, A. (1977). Social learning theory. Englewood Cliffs: Prentice Hall.

Bardi, A. \& Schwartz, S. H. (2003). Values and behavior: Strength and structure of relations. Personality and Social Psychology Bulletin, 29(10), 1207-1220.

Batista, V. M. (2003). O medo na cidade do Rio de Janeiro: dois tempos de uma história. Rio de Janeiro: Revan.

Bauman, Z. (2006). Liquid fear. Cambridge: Polity Press.

Baumer, T. L. (1985). Testing a general model of fear of crime: Data from a national sample. Journal of Research in Crime and Delinquency, 22, 239-255.

Beck, U. (1992). Risk society: Towards a new modernity. London, England: Sage.

Beck, V., Travis, I., \& Lawrence, F. (2004). Sex offender notification and fear of victimization. Journal of Criminal Justice, 32(5), 455-463.

Berkowitz, L., \& LePage, A. (1967). Weapons as aggression-eliciting stimuli. Journal of Personality and Social Psychology, 7, 202-207.

Biderman, A., Johnson, L., McIntyre, J., \& Weir, A. (1967). Report on a Pilot Study in the District of Columbia on Victimisation and Attitudes Toward Law Enforcement. President's Commission on Law Enforcement and Administration of Justice, Field Surveys I. Washington DC: US Government Printing Office.

Bortolatto Júnior, A. L. (2014). Hierarquia de Valores de alunos de Ciências Contábeis (Tese de doutorado). Universidade de São Paulo, São Paulo.

Bottoms, A. (2012). Developing socio-spatial criminology. In M. Maguire, R. Morgan \& R. Reiner. The Oxford Handbook of Criminology (pp. 450-489). Oxford: Oxford University Press.

Box, S., Hale, C., \& Andrews, G. (1988). Explaining fear of crime. The British Journal of Criminology, 28(3), 340-356.

Bowling, B. (1993). Racial harassment and the process of victimisation. British Journal of Criminology, 33, 231-250.

Brake, M., \& Hale, C. (1992). Public order and private lives: the politics of law and order. London: Routledge. 
Branscombe, N. R., Weir, J. A., \& Crosby, P. (1991). A three-factor scale of attitudes toward guns. Aggressive Behavior, 17, 261-273.

Brief, A. P., Dietz, J., Cohen, R. R., Pugh, S. D., \& Vaslow, J. B. (2000). Just doing business: modern racism and obedience to authority as explanations for employment discrimination. Organizational Behavior and Human Decision Processes, 81(1), 72-97.

Brown, B. B., Perkins, D. D., \& Brown, G. (2003). Place attachment in a revitalizing neighborhood: Individual and block levels of analysis. Journal of Environmental Psychology, 23, 259-271.

Brown, T. A. (2006). Confirmatory factor analysis for applied research. New York: Guilford Press.

Brunton-Smith, I., \& Sturgis, P. (2011). Do neighborhoods generate fear of crime? An empirical test using The British Crime Survey. Criminology, 49(2), 331-369.

Burke, R.H. (2005). An introduction to Criminological Theory. Cullompton: Willan.

Bursik, R., \& Grasmick, H. (1993). Neighborhoods and crime: The Dimensions of effective community control. New York: Lexington Books.

Byrne, B. M. (2010). Structural Equation Modeling Using AMOS. New York: Routledge.

Caprara, G. V., Renzi, P., Amolini, P., D'lmperio, G., \& Travaglia, G. (1984). The eliciting cue value of aggressive slides reconsidered in a personological perspective: the weapons effect and irritability. European Journal of Social Psychology, 14, 313-322.

Carlson, J., \& Hatfield, E. (1992). Psychology of emotion. Fort Worth: Harcourt, Brace \& Jovanovich.

Carvalho, E. (1910). A polícia carioca e a criminalidade contemporânea. Rio de Janeiro: Imprensa Nacional.

Carvalho, S. (2014). Criminologia Cultural. In R. S. Lima, J. L. Ratton, \& R. G. Azevedo (Orgs.), Crime, Polícia e Justiça no Brasil (pp. 138-147). São Paulo: Contexto.

Cattell, R., \& Scheier, I. (1961). The meaning and measurement of neuroticism and anxiety, New York: Ronald Press.

Ceobanu, A. M. (2010). Usual suspects? Public views about immigrants' impact on crime in European countries. International Journal of Comparative Sociology, 52(1-2), 114-131.

Chalhoub, S. (1988). Medo branco de almas negras: escravos libertos e republicanos na cidade do Rio de Janeiro. Revista Brasileira de História, 8(16), 83-105.

Chan, W., \& Rigakos, G. S. (2002). Risk, crime and gender. British Journal of Criminology, $42,743-761$.

Chancer, L., \& McLaughlin, E. (2007). Public criminologies: diverse perspective on academia and policy. Theoretical Criminology, 11(2), 155-173. 
Chevalier, L. (1973). Labouring classes and dangerous classes in Paris in the first half of nineteenth century. New York: Howard Festing.

Chiricos, T., Hogan, M., \& Gertz, M. (1997). Racial composition of neighborhood and fear of crime. Criminology, 35(1), 107-131.

Clarke, A. H., \& Lewis, M. (1982). Fear of crime among the elderly. British Journal of Criminology, 22, 49-62.

Cohen, M. A. (2008). The effect of crime on life satisfaction. Journal of Legal Studies, 37(June), S325-S353.

Cohen, S. (1972). Folk devils and moral panics: The creation of the mods and rockers. London: Paladin.

Cohen, S. (1996). Crime and politics: Spot the difference. The British Journal of Sociology, $47(1), 1-21$.

Collins, J. J., Cox, B. G., \& Langan, P. A. (1987). Job activities and personal crime victimization: Implications for theory. Social Science Research, 16(4), 345-360.

Companhia de Planejamento do Distrito Federal. Codeplan. (2013). Pesquisa Distrital por Amostra de Domicílios - Ceilândia - PDAD. Retirado de http://www.codeplan.df.gov.br/images/CODEPLAN/PDF/Pesquisas\%20Socioecon\%C3\% B4micas/PDAD/2013/Ceil\%C3\%A2ndia-PDAD\%202013.pdf.

Companhia de Planejamento do Distrito Federal. Codeplan. (2015). Pesquisa Distrital por Amostra de Domicílios - Ceilândia - PDAD. Retirado de http://www.codeplan.df.gov.br/images/CODEPLAN/PDF/pesquisa_socioeconomica/pdad /2015/PDAD_Ceilandia_2015.pdf.

Conklin, J. (1975). The impact of crime. New York: Macmillan.

Covington, J., \& Taylor, R. B. (1991). Fear of crime in urban residential neighborhoods: Implications of between- and within-neighborhood sources for current models. Sociological Quarterly, 32, 231-249.

Cozens, P., Hillier, D., \& Prescott, G. (2001). Crime and the the design of residential property - exploring the theoretical background - Part. 1. Property Management, 19, $136-164$.

Dear, M. (2000). The postmodern urban condition. Massachusetts: Blackwell.

De Coster, S., Estes, S. B., \& Mueller, C. W. (1999). Routine activities and sexual harassment in the workplace. Work and Occupations, 26(1), 21-49.

Demo, P. (1983). Introdução ao ensino de metodologia da ciência. In P. Demo (Ed.), Introdução ao ensino de Metodologia da Ciência (pp. 13-28). São Paulo: Atlas.

DETR, 1998. Personal security on public transport. Guidelines for operators. DETR Mobility Unit. Crown Copyright, London. 
Ditton, J., Bannister, J., Gilchrist, E., \& Farrall, S. (1999). Afraid or angry? Recalibrating the "fear" of crime. International Review of Victimology, 6, 83-99.

Ditton, J., \& Farrall, S. (2000). The Fear of Crime, Aldershot: Dartmouth Publishing.

Ditton, J., Khan, F., \& Chadee, D. (2005). Fear of crime quantitative measurement instability revisited and qualitative consistency added: Results from Three Wave Trinidadian Longitudinal Study. International Review of Victimology, 12(3), 247-271.

Doob, L. W. (1947). The behavior of attitudes. Psychological Review, 54, 135-156.

Doran B. J., \& Burgess M. B. (2012). Putting fear of crime on the map: Investigating perceptions of crime using geographic information systems. Canberra: Springer Science \& Business Media.

Douglas, S. C., \& Martinko, M. J. (2001). Exploring the role of individual differences in the prediction of workplace aggression. Journal of Applied Psychology, 86(4), 547-559.

Dowds, L., \& Ahrendt, D. (1995). Fear of crime. In R. Jowell et al. (Eds.), British Social Attitudes: 12th Report. Aldershot: Dartmouth.

Dowler, K. (2002). Media influence on attitudes toward guns and gun control. American Journal of Criminal Justice, 26(2), 235-247.

Dreyfus, P., \& Nascimento, M. S. (2005). Small arms holdings in Brazil: Toward a comprehensive mapping of guns and their owners. In R. Fernandes (Ed.). Brazil: The Arms and the Victims. Rio de Janeiro: 7 Letras/Viva Rio/ISER.

DuBow, F., McCabe, E., \& Kaplan, G. (1979). Reactions to crime: A critical review of the literature. National Institute of Law Enforcement and Criminal Justice. Washington, D.C.: U.S. Government Printing Office.

Dugan, L. (1999). The effect of criminal victimisation on a household's moving decision. Criminology, 37(4), 903-930.

Eagly, A. H., \& Chaiken, S. (1993). The psychology of attitudes. Fort Worth: Harcourt, Brace \& Jovanovich.

Edmondson, B. (1994). Most homes armed. American Demographics, 16(10): 19-27.

Egger, S. (1997). Women and crime prevention. In P. O’Malley, \& A. Sutton (Eds). Crime Prevention in Australia: Issues in policy and research (pp. 84-104). Leichhardt: Federation Press.

Emsley, C. (1987). Crime and Society in England 1750-1900. New York: Longman.

Ennis, P. (1967). Criminal Victimisation in the United States: A Report of a National Survey. President's Commission on Law Enforcement and the Administration of Justice, Field Surveys II. Washington DC: Government Printing Office.

Evans, K., Fraser, P., \& Walklate, S. (1996). "Whom can you trust? The politics of 'grassing' on an inner city housing estate". Sociological Review, 44, 3, 361-380. 
Ewald, U. (2000). Criminal victimisation and social adaptation in modernity: Fear of crime and risk perception in the new Germany. In T. Hope \& R. Sparks (Eds.), Crime, risk and insecurity: Law and order in everyday life and political discourse (pp. 166-199). London: Routledge.

Farrall, S., Bannister, J., Ditton, J., \& Gilchrist, E. (1997). Questioning the Measurement of the "Fear of Crime". The British Journal of Criminology, 37(4), 658-679.

Farrall, S., \& Gadd, D. (2004). The frequency of the fear of crime. British Journal of Criminology, 44(1), 127-132.

Farrall, S., Gray, E., \& Jackson, J. (2007). Theorising the fear of crime: The cultural and social significance of insecurities about crime. Experience \& Expression in the Fear of Crime Working Paper $n^{0}$ 5. Retirado de http://dx.doi.org/10.2139/ssrn.1012393.

Farrall, S., Jackson, J., \& Gray, E. (2009). Social order and the fear of crime in contemporary times. Oxford: Oxford University Press.

Farrall, S., \& Lee, M. (2009). Critical voices in an age of anxiety. Oxon, UK: Routledge.

Fattah, E. A., \& Sacco, V. F. (1989). Crime and victimization of the elderly. New York: Springer-Verlag.

Feather, N. T. (1995). Values, valences, and choice: The influence of values on the perceived attractiveness and choice of alternatives. Journal of Personality and Social Psychology, $68,1135-1151$.

Fenton, F. (1911). The influence of newspaper presentations upon growth of crime and other anti-social activity. Chicago: The University of Chicago Press.

Fere, C. (1888). Notes on change in electrical resistance under the effect of sensory stimulation and emotion. Comptes rendues des séances de la société de biologie, 5, 217 219.

Ferguson, K. M., \& Mindel, C. H. (2007). Modeling fear of crime in Dallas neighborhoods: A test of social capital theory. Crime \& Delinquency, 53(2), 322-349.

Ferraro, K.F. (1995) Fear of crime: Interpreting victimisation risk. Albany: State University of New York Press.

Ferraro, K. F., \& LaGrange, R. (1987). The measurement of fear of crime. Sociological Inquiry, 57(1), 70-101.

Ferraro, K. F., \& LaGrange, R. (1992). Are older people most afraid of crime? Reconsidering age differences in fear of victimization. Journal of Gerontology, 45(5), 233-244.

Ferraro, K. F., \& LaGrange, R. (2000). The measurement of fear of crime. In J. Ditton \& S. Farrall (Eds.), The fear of crime (pp. 277-308). New York: Ashgate.

Festinger, L. (1957). A theory of cognitive dissonance. Evanston: Row Peterson.

Field, A. P. (2009). Discovering statistics with SPSS. London, Sage. 
Fishbein, M. (1966). The Relationships between Beliefs, Attitudes and Behavior. In S. Feldman (Ed.), Cognitive Consistency (pp. 199-223). New York: Academic Press.

Fishbein, M., \& Ajzen, I. (1975). Belief, attitude, intention, and behavior: An introduction to theory and research. Reading: Addison-Wesley.

Fisher, B. S., \& Sloan, J. J., III. (2003). Unraveling the fear of victimization among college women: Is the "shadow of sexual assault hypothesis" supported? Justice Quarterly, 20(3), 633-659.

Fonseca, A. M. O., Porto, J. B., \& Barroso, A. C. (2012). O efeito de valores pessoais nas atitudes perante estilos de liderança. Revista de Administração Mackenzie (Online), 13, 122-149.

Foucault, M. (1970). The order of things: An archaeology of the human sciences. New York: Vintage Books.

Frattari, N. F. (2013). As configurações sociais do medo do crime na cidade de Goiânia (Tese de doutorado). Universidade de Brasília, Brasília.

Frijda, N. (1993). Moods, emotion episodes and emotions. In M. Lewis (Ed.), Handbook of Emotions, (pp. 381-404). New York: The Guildford Press.

Furedi, F. (1998). Culture of fear: Risk taking and the morality of low expectation. London: Cassell.

Gabriel, U., \& Greve, W. (2003). The psychology of fear of crime: Conceptual and methodological perspectives. British Journal of Criminology, 43(3), 600-614.

Gardner, J. (1990). Victims and criminal justice. Adelaide: Office of Crime Statistics, Attorney-General's Department.

Garland, D. (2001). The Culture of Control: crime and social order in contemporary society. Oxford: Oxford University Press.

Garofalo, J. (1979). Victimization and the fear of crime. Journal of Research in Crime and Delinquency, 16, 80-97.

Garofalo, J. (1981). The fear of crime: Causes and consequences. Journal of Criminal Law and Criminology, 72(2), 839-857.

Garofalo, J. (1987). Reassessing the lifestyle model of criminal victimization. In M. Gottfredson, \& T. Hirschi (Eds.), Positive Criminology (pp. 23-42). Newbury Park: Sage.

Garofalo, J., \& Laub, J. (1978). The fear of crime: Broadening our perspective. Victimology: An International Journal, 3, 242-253.

Gibson, C. L., Zhao, J., Lovrich, N. P., \& Gaffney, M. J. (2002). Social integration, individual perceptions of collective efficacy, and fear of crime in three cities. Justice Quarterly, 19, 537-564.

Giddens, A. (1990). The consequences of modernity. Cambridge: Polity Press. 
Giddens, A. (1991). Modernity and self-identity. Cambridge, England: Polity Press.

Girling, E., Loader, I., \& Sparks, R. (2000). Crime and social control in Middle England: Questions of order in an english town. London: Routledge.

Giroux, S., \& Tremblay, G. (2004). Metodología de las ciencias humanas: La investigación en acción. México: FCE.

Goergen P. (2005). Educação e valores no mundo contemporâneo. Educ. Soc., 26(92), 983 1011

Golant, S. (1984). Factors influencing the night time activity of old persons in their community. Journal of Gerontology, 39, 485-491.

Goodey, J. (1994). Fear of crime: What can children tell us? International Review of Victimology, 3, 195-210.

Gordon, M. T., \& Riger, S. (1989). The female fear. New York: Free Press.

Gorman-Smith, D., Tolan, P. H., \& Henry, D. (2000). A developmental-ecological model of the relation of family functioning to patterns of delinquency. Journal of Quantitative Criminology, 16(2), 169-198.

Gottfredson, M. R. (1984). Victims of crime: the dimensions of risk. London, H.M.S.O.

Gouveia, V. V., Pimentel, C. E., Leite, P. R. L., Albuquerque, J. R., \& Costa, T. A. B. (2009). Escala de atitudes frente o uso de álcool: Descrevendo seus parâmetros psicométricos. Psicologia: Ciência e Profissão, 29(4), 672-685.

Gouveia, V. V., Pimentel, C. E., Medeiros, E. D., Gouveia, R. S. V., \& Palmeira, J. (2007). Escala de atitudes frente ao uso de drogas: evidências de validade fatorial e preditiva. Jornal Brasileiro de Psiquiatria, 56(1), 53-59.

Gouveia, V. V., Pimentel, C. E., Queiroga, F., Meira, M., \& Jesus, G. R. (2005). Escala de atitudes frente ao uso de maconha: comprovação de sua validade de construto. Jornal Brasileiro de Psiquiatria, 54(1), 5-12.

Gray, E., Jackson, J., \& Farrall, S. (2008). Reassessing the fear of crime. European Journal of Criminology, 5(3), 363-380.

Gray, E., Jackson, J., Farrall, S. (2011) Feelings and functions in the fear of crime: applying a new approach to victimisation insecurity. British Journal of Criminology, 51(1), 75-94.

Greenberg, S. W. (1986). Fear and its relationship to crime, neighborhood deterioration, and informal social control. In J. M. Byrne \& R. J. Sampson (Eds.), Social ecology of crime (pp. 47-62). New York: Springer-Verlag.

Haddock, G., \& Maio, G. R. (2015). Attitudes. In M. Hewstone, W. Stroebe, \& K. Jonas (Eds.). Social Psychology (6th ed., pp. 171-201). New York: Wiley.

Hair, F. J., Black, W.C., Babin, B., Anderson, R. E., \& Tathan, R. L. (2009). Análise multivariada de dados. Porto Alegre: Bookman. 
Hale, C. (1996). Fear of crime: a review of the literature. International Review of Victimology, 4(2), 79-150.

Hanslmaier, M. (2013). Crime, fear and subjective well-being: How victimization and street crime affect fear and life satisfaction. European Journal of Criminology, 10(5), 515-533.

Harris, R. (1969). The Fear of Crime. New York: Frederick A. Praeger.

Hayward, K. (2004). City limits: Crime, consumer culture and the urban experience. London: Glasshouse.

Healy, M. J. R. (1984). The use of $\mathrm{R}^{2}$ as a measure of goodness of fit. Journal of Royal Statistical Society, 147, 608-609.

Henrich, J., Heine, S. J., \& Norenzayan, A. (2010). The weirdest people in the world? Behavioral and Brain Sciences, 33(2-3), 61-83.

Hinkle, J. C., \& Yang, S. M. (2014). A new look into broken windows: what shapes individual's perceptions of social disorder? Journal of Criminal Justice, 42(1), 26-35.

Hirtenlehner, H. (2008). Disorder, social anxieties and fear of crime. Exploring the relationship between incivilities and fear of crime with a special focus on generalized insecurities. In H. Kury (Ed.), Fear of crime - Punitivity: New developments in theory and research (pp. 127-158). Bochum: Brockmeyer.

Hirtenlehner, H. (2011). The origins of punitive mentalities in late-modern societies. Testing an expressive explanatory model. In H. Kury \& E. Shea (Eds.), Punitivity. International developments: Punitiveness - A global phenomenon? (vol. 1, pp. 27-51). Bochum: Brockmeyer.

Hirtenlehner, H. \& Farrall, S. (2013). Anxieties about modernization, concerns about community, and fear of crime: Testing two related models. International Criminal Justice Review, 23(1), 5-24.

Hofstede, G. (1980). Culture's consequences. Beverly Hills: Sage.

Hogg, R., \& Brown, D. (1998). Rethinking law and order. Annandale: Pluto Press.

Hollander, J. A. (2001). Vulnerability and dangerousness: The construction of gender through conversation about violence. Gender \& Society, 15, 83-109.

Hollander, J. A. (2002). Resisting vulnerability: The social reconstruction of gender in interaction. Social Problems, 49, 474-496.

Hollway, W., \& Jefferson, T. (1997). The risk society in an age of anxiety: situating fear of crime. The British Journal of Sociology, 48(2), 255-266.

Holmes, J. (1929). Crime and the press. Journal of the American Institute of Criminal Law and Criminology, 20(1), 6-59.

Homer, P., \& Kahle, L. (1988). A structural equation test of the 'Value-Attitude-Behaviour Hierarchy. Journal of Personality and Social Psychology, 54(winter), 638-664. 
Hood, R., \& Sparks, R. (1970). Key issues in criminology. London: Weidenfeld and Nicolson.

Hope, T., \& Sparks, R. (2000). Introduction. In T. Hope and R. Sparks (Eds.), Crime, Risk and Insecurity (pp. 15-24). London: Routledge.

Hough, M., \& Mayhew, P. (1985). Taking account of crime: Key findings from the 1984 British Crime Survey. London: HMSO.

Hovland, C. I., Janis, I. L., \& Kelley, H. H. (1953). Communication and persuasion. New Haven, CT: Yale University Press.

Hoyle, C., \& Zedner, L. (2002). Victims, victimizations, and criminal. In M. Maguire, R. Morgan, \& R. Reiner (Eds). The Oxford Handbook of Criminology (pp. 461-495). Oxford: Clarendon Press.

Hu, L. \& Bentler, P. M. (1999). Cutoff criteria for fit indexes in covariance structure analysis: Coventional criteria versus new alternatives. Structural Equation Modeling, 6(1), 1-55.

Inglehart, R. (1997). Modernization and post-modernization: Cultural, economic and political change in 43 societies. Princeton: Princeton University Press.

Innes, M. (2004). Signal crimes and signal disorders'. British Journal of Sociology, 55, 335355.

Jackson, J. (2004). Experience and expression: social and cultural significance in the fear of crime. The British Journal of Criminology, 44(6), 946-966.

Jackson, J. (2006). Validating new measures of the fear of crime. International Journal of Social Research Methodology, 8(4), 297-315.

Jackson, J. (2008). Bridging the social and the psychological in the fear of crime. In M. Lee, \& S. Farrall (Eds.), Fear of Crime: Critical Voices in an Age of Anxiety (pp. 143-167). Abingdon, UK: Glass House Press.

Jackson, J. (2009). A psychological perspective on vulnerability in the fear of crime. Psychology, Crime and Law, 15(4), 365-390.

Jackson, J. (2011). Revisiting risk sensitivity in the fear of crime. Journal of Research in Crime and Delinquency, 48(4), 513-537.

Jackson, J. (2015). Cognitive closure and risk sensitivity in the fear of crime. Legal and Criminological Psychology, 20(2), 222-240.

Jackson, J., Allum, N., \& Gaskell, G. (2006) Bridging levels of analysis in risk perception research: the case of the fear of crime. Forum Qualitative Sozialforschung / Forum: Qualitative Social Research, 7(1), Art. 20. Retirado de http://eprints.lse.ac.uk/15516/1/Bridging\%20levels\%20of\%20analysis\%20in\%20risk\%20 perception\%20research\%20\%28LSE\%20RO\%29.pdf.

Jackson, J., Farrall, S., Gray, E., \& Kuha, J. (2008). A New way of measuring the fear of crime. London: LSE. 
Jackson, J., \& Gouseti, I. (2014). Fear of crime and the psychology of risk. In G. Bruinsma, \& D. Weisburd (Eds.), Encyclopedia of criminology and criminal justice, (pp. 15941603). New York: Springer.

Jackson, J., \& Sunshine, J. (2007). Public confidence in policing: a neo-Durkheimian perspective. British Journal of Criminology, 47(2), 214-233.

Jones, T., MacLean, B., \& Young, J. (1986). The Islington Crime Survey: Crime, Victimisation and Policing in Inner-City London. Aldershot: Gower Publishing Co. Ltd.

Kaiser, H. F. (1974). An index of factorial simplicity. Psychometrika, 39, 31-36.

Kant, I. (1788/2002). Crítica da Razão Prática (V. Rohden, trad.) São Paulo: Martins Fontes.

Katz, D. (1960). The functional approach to the study of attitudes. Public Opinion Quarterly, 24, 163-204.

Katz, D., \& Stotland, E. (1959). A preliminary statement of a theory of attitude structure and change. In S. Koch (Ed.). Psychology: a Study of a Science (vol. III, pp. 423-475). New York: McGraw-Hill.

Keane, C. (1995). Victimisation and fear: Assessing the role of offender and offence. Canadian Journal of Criminology, 37(3), 431-455.

Keane, C. (1998). Evaluating the Influence of Fear of Crime as an Environmental Mobility Restrictor on Women's Routine Activities. Environment and Behavior, 60-74.

Kelly, L. (1987). The continuum of sexual violence. In J. Hamner \& M. Maynard (Eds.), Women, Violence, and Social Control, (pp. 46-60). Atlantic Highlands, NJ: Humanities Press International.

Khaptsova, A., \& Schwartz, S. H. (2016). Life Satisfaction and Value Congruence: Moderators and extension to constructed socio-demographic groups in a Russian National Sample. Social Psychology, 47(3), 163-173.

Killias, M., (1990). Vulnerability: towards a better understanding of a key variable in the genesis of fear of crime. Violence and Victims, 5(2), 97-108.

Killias, M., \& Clerici, C. (2000). Different measures of vulnerability in their relations to different dimensions of fear of crime. British Journal of Criminology, 40(3), 437-450.

Kline, R. B. (2010). Principles and practice of structural equation modeling. New York: The Guilford Press.

Kluckhohn, C. (1951). Values and value-orientations in the theory of action: An exploration in definition and classification. In T. Parsons, \& E. Shils (Orgs.). Toward a general theory of action (pp. 469-506). Cambridge: Harvard University Press.

Kodellas, S., Fisher, B. S., \& Wilcox, P. (2015). Situational and dispositional determinants of workplace victimization: The effects of routine activities, negative affectivity, and low self-control. International Review of Victimology, 21(3), 321-342. 
Kristiansen, C. M., \& Zanna, M. P. (1988). Justifying attitudes by appealing to values: A functional perspective. British Journal of Social Psychology, 27(3), 247-256.

Krosnick, J. A., \& Petty, R. E. (1995). Attitude strength: An overview. In R. E. Petty \& J. A. Krosnick (Eds.), Attitude strength: Antecedents and consequences (pp. 1-24). Mahwah, NJ: Lawrence Erlbaum Associates.

LaGrange, R., \& Ferraro, K. F. (1987). The elderly's fear of crime: A critical examination of the research. Research on Aging, 9, 372-391.

LaGrange, R. L., \& Ferraro, K. F. (1989). Assessing age and gender differences in perceived risk and fear of crime. Criminology, 27, 697-719.

LaGrange, R. L., Ferraro, K. F., \& Supancic, M. (1992). Perceived risk and fear of crime: Role of social and physical incivilities. Journal of Research in Crime and Delinquency, 29(3), 311-334.

Landau, S. F., \& Bendalak, Y. (2008) Personnel exposure to violence in hospital emergency wards: A routine activity approach. Aggressive Behavior, 34(1), 88-103.

Lane, J., Rader, N. E., Henson, B., Fisher, B. S., \& May, D. C. (2014). Fear of crime in the United States: causes, consequences and contradictions. Durham, NC: Carolina Academic Press.

Langeani, B., \& Pollachi, N. (2016). Panorama das Apreensões de Armas no Brasil em 2016. In Fórum Brasileiro de Segurança Pública, $10^{\circ}$ Anuário Brasileiro de Segurança Pública (pp. 50-59). Brasília: FBSP.

Langen, N. (1888). Beiträge zur theorie der sinnlichen aufmerksamkeit and der aktiven apperception. Phil. Stud., 4, 390-422.

LaPiere, R. T. (1934). Attitudes versus actions. Social Forces, 13, 230-237.

Laville, C., \& Dionne, J. (1999). A construção do saber. Porto Alegre: Artmed.

Lee, G. R. (1982). Residential location and fear of crime among the elderly. Rural Sociology, 47, 655-669.

Lee, M. (2011). Inventing fear of crime: Criminology and politics of anxiety. New York: Routledge.

Lee, M. (2008). Inventing fear of crime: Criminology and the politics of anxiety. The Howard Journal of Crime and Justice, 47(5), 564-565.

Leyens, J. P., \& Parke, R. D. (1975). Aggressive slides can induce a weapons effect. European Journal of Social Psychology, 5, 229-236.

Lewin, K. (1942). Field theory and learning. In Cartwright D. (Ed.). Field theory in social science (pp. 60-86). New York: Harper \& Row.

Lewis, D. A., \& Maxfield, M. G. (1980). Fear in the neighbourhoods: An investigation of the impact of crime. Journal of Research and Delinquency, 17, 160-189. 
Lewis, D. A., \& Salem, G. (1980). Community crime prevention: An analysis of a developing strategy. Manuscrito não publicado. North-Western University.

Lewis, D. A., \& Salem, G. (1981). Community crime prevention: an analysis of a developing strategy. Crime and Delinquency, 27, 405-421.

Lewis, D. A., \& Salem, G. (1986). Fear of crime: Incivility and the production of a social problem. New Brunswick: Transaction Books.

Liebnitzky, J., \& Montero, M. (2013). Miedo al crimen en estudiantes de la ciudad de Caracas. Psicologia \& Sociedade, 25(1), 152-162.

Likert, R. (1932). A new technique for the measurement of attitudes. Archives of Psychology, $140,5-53$.

Lima, R. S. (2006). Desbravando antigos e novos territórios, Resenha. Revista Brasileira de Estudos da População, 23, 195-197.

Liska, A., Sanchirico, A., \& Reede, M. (1988). Fear of crime and constrained behaviour: Specifying and estimating a reciprocal effects model. Social Forces, 66, 827-837.

Loader, I. (1999). Consumer culture and the commodification of policing and security. Sociology, 33(2), 373-392.

Loader, I., Girling, E., \& Sparks, R. (2000). After success: Anxieties of influence an english village. In T. Hope \& R. Sparks (Eds.), Crime, risk and insecurity: Law and order in everyday life and political discourse (pp.65-82). London: Routledge.

Loewenstein, G. F., Weber, E. U., Hsee, C. K., \& Welch, E. S. (2001). Risk as feelings. Psychol Bull, 127(2), 267-286.

Lombroso, C. (1897/2004). Why homicide has increased in the United States. In D. Horton \& K. Rich (Eds.). The criminal anthropological writings of Cesare Lombroso in the english language. Lampeter: The Edwin Mellen Press.

Lorenc, T., Clayton, S., Neary, D., Whitehead, M., Petticrew, M., Thomson, H., \& Renton, A. (2012). Crime, fear of crime, environment, and mental health and wellbeing: Mapping review of theories and causal pathways. Health \& Place, 18, 757-765.

Luo, F., Ren, L., \& Zhao, J. S. (2016). Location-based fear of crime: A case study in Houston, Texas. Criminal Justice Review, 41(1), 75-97.

Lupton, D. (1999). Dangerous places and the unpredictable stranger. Australian and New Zealand Journal of Criminology, 32(1), 1-15.

Lupton, D., \& Tulloch, J. (1999). Theorizing fear of crime: Beyond the rational / irrational opposition. British Journal of Sociology, 50(3), 507-523.

Lynch, J. (1987). Routine activity and victimization at work. Journal of Quantitative Criminology, 3(4), 283-300. 
Mackenzie, S. B. (1986). The role of attention in mediating the effect of advertising on attribute importance. Journal of Consumer Research, 13(2), 174-195.

Madriz, E. (1997). Nothing bad happens to good girls: Fear of crime in women's lives. Berkeley: University of California Press.

Maio, G. R., \& Haddock, G. (2015). The psychology of attitudes and attitude change. New Delhi: Replika Press Pvt Ltd.

Marmot, M. G. (2004). Status syndrome: How your social standing directly affects your health and life expectancy. London: Bloomsbury.

Marôco, J. (2010). Análise de equações estruturais: fundamentos teóricos, software e aplicações. Pero Pinheiro: Report Number.

Marôco, J. (2011). Análise estatística com o SPSS Statistics. Pero Pinheiro: Report Number.

Martino, F. A. (2016). Seleção de um banco principal por prefeitos municipais: A influência de valores individuais e beneficios esperados (Dissertação de Mestrado). Universidade de Brasília, Brasília.

Maslow, A. B. (1971). La personalidad creadora. Barcelona: Editorial Kairós.

Maxfield, M.G. (1984). Fear of crime in England and Wales. London: Her Majesty's Stationery Office.

Maxfield, M. G. (1987). Explaining fear of crime: evidence from the 1984 British Crime Survey. Home Office Research and Planning Unit. London: HMSO.

McConville, M., \& Shepard, D. (1992). Watching police, watching communities. London and New York: Routledge.

McCrea, R., Shyy, T-K., Western, J., \& Stimson, R. J. (2005). Fear of crime in Brisbane: Individual, social and neighborhood factors in perspective. Journal of Sociology, 41(7), 727.

McGuire, W. J. (1985). Attitudes and attitude change. In G. Lindzey \& E. Aronson (Eds.). The handbook of social psychology (3rd ed., vol. 2, pp. 233-346). New York: Random House.

McGuire, W. J. (1986). The vicissitudes of attitudes and similar representational constructs in twentieth century psychology. European Journal of Social Psychology, 16(2), 89-130.

Mcquilkin, J., Garðarsdóttir, R. B., Thorsteinsson, T. \& Schwartz, S. H. (2016). An icelandic translation and validation of the revised 19-value Portrait Values Questionnaire. Personality and Individual Differences, 101, 428-434.

Mellena, A., \& Bassili, J. N. (1995). On the relationship between attitudes and values: Exploring the moderating effects of self-monitoring and self-monitoring schematicity. Personal Social Psychology, 21(9), 885-892. 
Mendelsohn, B. (1956). The Victimology. Etudes Internationales de Psycho-Sociologie Criminelle, 56(3), 25-26.

Merry, S. (1981). Urban danger: Life in a neighborhood of strangers. Philadelphia: Temple University Press.

Mesch, G. S. (2000). Perceptions of risk, lifestyle activities, and fear of crime. Deviant Behavior, 21, 47-62.

Michalos, A. C., \& Zumbo, B. D. (2000). Criminal victimization and the quality of life. Social Indicators Research, 50(3), 245-295.

Miethe, T. (1995). Fear and withdrawal from urban life. Annals of the American Academy of Political and Social Sciences, 539, 14-27.

Mills, C. W. (1964). Two styles of social science research. In I. Horowitz (Ed.), Power, politics, and people: The collected writings of C. Wright Mills (pp. 553-568). New York: Oxford University Press.

Moore, S. C. (2006). The value of reducing fear: An analysis using the European Social Survey. Applied Economics, 38(1), 115-117.

Mora, M. N. (2009). El miedo al delito no es un supuesto de victimización indirecta. International e-Journal of Criminal Science, 3(3), 1-40.

Morris, C. (1956). Varieties of human value. Chicago: The University of Chicago Press.

Mustaine, E. E., \& Tewksbury, R. (1997). The risk of victimization in the workplace for men and women: An analysis using Routine Activities/Lifestyles Theory. Humanity and Society, 21(1), 17-38.

Nascimento, T. G., Torres, C. V., \& Pimentel, C. E. (2011). Evidências de validade e precisão da escala de atitudes frente à polícia. Revista Brasileira de Segurança Pública, $5(9), 42-56$.

Nascimento, T. G., Pimentel, C. E., \& Adaid-Castro, B. G. (2016). Escala de atitudes frente à arma de fogo (AFAF): Evidências de sua adequação psicométrica. Psicologia: Teoria e Pesquisa, 32(1), 239-248.

Neder, G. (1997). Cidade, identidade e exclusão social. Revista Tempo, 2(3), 106-134.

Neiva, E. R., Abbad, G., \& Tróccoli, B. T. (2007). Roteiro para análise factorial de dados. Manuscrito não publicado. Instituto de Psicologia, Universidade de Brasília.

Neiva, E. R., \& Mauro, T. G. (2011). Atitude e mudança de atitudes. In C. V. Torres \& E. R. Neiva (Orgs.). Psicologia social: Principais temas e vertentes (pp. 171-203). Porto Alegre: Artmed.

Norris, F. H., \& Kaniasty, K. (1994). Psychological distress following criminal victimization in the general population: Cross-sectional, longitudinal, and prospective analyses. Journal of Consulting and Clinical Psychology, 62, 111-123. 
O’Malley, P. (1992). Risk, power, and crime prevention. Economy and Society, 21, 252-275.

Oslon, J. M., \& Maio, G. R. (2003). Attitudes in social behavior. In M. J. Lerner (Ed.). Handbook of psychology (vol. 5, pp. 299-325). Hoboken: Wiley.

Pain, R. (1997). Whither women's fear? Perceptions of sexual violence in public and private space. International Review of Victimology, 4, 297-312.

Pain, R. (2000). Place, social relations and the fear of crime: A review. Progress in Human Geography, 24(3), 365-387.

Pain, R. (2001). Gender, race, age and fear in the city. Urban Studies, 38, 899-913.

Parsons, T. (1937). The structure of social action. New York: McGraw \& Hill.

Parsons, T. (1959). El sistema social. Madri: Revista de Occidente.

Parsons, T., \& Shils, E. A. (1951). Towards a general theory of action. Harvard: Harvard University Press.

Pasquali, L. (1999). Instrumentos psicológicos: Manual prático de elaboração. Brasília: LabPAM/IBAPP.

Pasquali, L. (2003). Os tipos humanos: A teoria da personalidade. Petrópolis: Vozes.

Pasquali, L. (2006). Análise fatorial para pesquisadores. Brasília: LabPAM.

Pasquali, L. (2010). Testes referentes a constructos: teoria e modelo de construção. In L. Pasquali et al., Instrumentação Psicológica: fundamentos e práticas (pp. 165-198). Porto Alegre: Artmed.

Paulino, I. R. (2006). Um olhar sobre a degradação dos valores humanos a partir da obra Os Sonâmbulos, de Hermann Broch (Dissertação de Mestrado). Universidade de Brasília, Brasília.

Perkins, D., \& Taylor, R. (1996). Ecological assessments of community disorder: Their relationship to fear of crime and theoretical implications. American Journal of Community Psychology, 24, 63-107.

Perkins, D., Wandersman, A., Rich, R. C., \& Taylor, R. B. (1993). The physical environment of street crime: Defensible space, territoriality and incivilities. Journal of Environmental Psychology, 13, 29-49.

Peterson, R. A. (2001). On the use of college students in social science research: Insights from a second-order meta-analysis. Journal of Consumer Research, 28, 450-461.

Petty, R. E., Wegener, D. T., \& Fabrigar, L. R. (1997). Attitudes and attitude change. Annual Review of Psychology, 48, 609-647.

Phillips, L. M. (2000). Flirting with danger: Young women's reflections on sexuality and domination. New York: New York University Press. 
Pike, L.O. (1968). A history of crime in England. New Jersey: Patterson Smith.

Pike, S., \& Ryan, C. (2004). Destination positioning analysis through a comparison of cognitive, affective, and conative perceptions. Journal of Travel Research, 42(4), 333-342.

Pimentel, C. E., Günther, H., \& Black, P. U. V. (2012). Acessando o medo do crime: Um survey por meio da internet. Psicologia Argumento, 30(69), 2012.

Pimentel, C. E., Torres, C. V., \& Günther, H. (2011). Estratégias de mensuração de atitudes em psicologia social. In C. V. Torres \& E. R. Neiva (Orgs.). Psicologia social: Principais temas e vertentes (pp. 204-218). Porto Alegre: Artmed.

Pitner, R. O., Yu, M. S., \& Brown, E. (2012). Making neighborhoods safer: Examining predictors of resident's concerns about neighborhood safety. Journal of Environmental Psychology, 32, 43-49.

Porto, M. S. (2014). Violência e representações sociais. In R. S. de Lima, J. L. Ratton \& R. G. de Azevedo (Orgs.), Crime, Polícia e Justiça no Brasil (pp. 60-70). São Paulo: Contexto.

Quetelet, A. (1984). Adolphe Quetelet's Research on the propensity for crime at different ages (trad. S. F. Sylvester). Cincinnati: Anderson Publishing Co.

Rader, N. E., Cossman, J. S., \& Porter, J. R. (2012). Fear of crime and vulnerability: Using a national sample of Americans to examine two competing paradigms. Journal of Criminal Justice, 40(2), 134-141.

Radzinowicz, L. (1999). Adventures in Criminology. London: Routledge.

Raudenbush, S.W., \& Sampson, R. J. (1999). Ecometrics: toward a science of assessing ecological settings, with application to the systematic social observation of neighbourhoods. Sociological Methodology, 29(1), 1-41.

Refinetti, R. (1996). Demonstrating the consequences of violations assumptions in analysis of variance. Teaching of Psychology, 23, 51-54.

Reigh, B. \& Adcock, C. (1976). Valores, atitudes e mudança de comportamento. Rio de Janeiro: Zahar.

Reiner, R., Livingston, S., \& Allen, J. (2000). No more happy endings: The media and popular concern about crime since the Second World War. In T. Hope \& R. Sparks (Eds). Crime, Risk and Insecurity (pp.107-126). London: Routledge.

Reiss, A. (1967). Studies in Crime and Law Enforcement in Major Metropolitan Areas, Volume 1. President's Commission on Law Enforcement and the Administration of Justice, Field Surveys III. Washington DC: US Government Printing Office.

Rengifo, A. F., \& Bolton, A. (2012). Routine activities and fear of crime: Specifying individual-level mechanisms. European Journal of Criminology, 9(2), 99-119.

Reuband, K. (2009). Portrayals of crime in the German mass media: Trends, patterns and impact on fear of crime. In Mesko, G., Cockroft T., Crawford A. \& Lemaitre, A. (Eds.) 
Crime media and fear of crime (pp. 163-185). Ljubljana, Slovenia: Tipografija Publishing.

Robinson, B. (1999). What you don't know can hurt you: Perceptions and misconceptions of harmful behaviors among criminology and criminal justice students. Western Criminology Review, 2(1). Disponível em: http://wcr.sonoma.edu/v2n1/robinson.html.

Robinson, J. B., Lawton, B. A., Taylor, R. B., \& Perkins, D. D. (2003). Multilevel longitudinal impacts of incivilities: fear of crime, expected safety, and block satisfaction. Journal of Quantitative Criminology, 19(3), 237-274.

Rokeach, M. (1973). The nature of human values. New York: Free Press.

Rokeach, M. (1981). Crenças, atitudes e valores. Rio de Janeiro: Interciência.

Ros, M. (2006). Psicologia social dos valores: uma perspectiva histórica. In M. Ros, \& V. V. Gouveia (Eds.). Psicologia social dos valores humanos: Desenvolvimentos teóricos, metodológicos e aplicados (pp. 23-53). São Paulo: Senac.

Rose, N. (1999). Powers of freedom: Reframing political thought. Cambridge: Cambridge University Press.

Ross, C. E., \& Jang, S. (2000). Neighborhood disorder, fear and mistrust: The buffering role of social ties with neighbours. American Journal of Community Psychology, 28, 401-420.

Rountree, P. W. (1998). A reexamination of the crime-fear linkage. Journal of Research in Crime and Delinquency, 35, 341-372.

Rountree, P. W., \& Land, K. C. (1996). Perceived risk versus fear of crime: Empirical evidence of conceptually distinct reactions in survey data. Social Forces, 74(4), 13531376.

Rozin, P. (2001). Social psychology and science: Some lessons from Solomon Asch. Personality and Social Psychology Review, 5, 2-14.

Sampson, R. J., Raudenbush, S. W., \& Earls, F. (1997). Neighborhoods and violent crime: A multilevel study of collective efficacy. Science, 277, 918-924.

Santos, L. B. (2016). Realização de Valores Pessoais no ambiente organizacional como componente de compatibilidade individuo-organização percebida e sua influência em intenção de saída (Tese de doutorado). Universidade Presbiteriana Mackenzie, São Paulo.

Santos Júnior, A. A., \& Henrique, J. M. (2005). Conjecturas acerca do arquétipo de atuação policial militar e perspectivas futuras. Revista Visão Global, 8(30), 131-141.

Schafer, S. (1968). The victim and his criminal: A Study in functional responsibility. New York: Random House.

Schreck, C. J., Wright, R. A., \& Miller, J. M. (2002). A study of individual and situational antecedents of violent victimization. Justice Quarterly, 19(1), 159-180. 
Schwartz, S. H. (1992). Universals in the content and structure of values: theoretical advances and empirical tests in 20 countries. In M. Zanna (Org.). Advances in Experimental Social Psychology (vol. 25, pp. 1-65). Orlando: Academic.

Schwartz, S. H. (1994). Are there universal aspects in the structure and contents of human values? Journal of Social Issues, 50(4), 19-45.

Schwartz, S. H. (1996). Value priorities and behavior: Applying a theory of integrated value systems. Em C. Seligman, J. M. Olson, \& M. P. Zanna (Orgs.), The psychology of valuesThe Ontario Symposium, (pp.1-24). Hillsdale: Lawrence Erlbaum Associates.

Schwartz, S. H. (2005). Valores humanos básicos: seu contexto e estrutura intercultural. In: Tamayo, A.; Porto, J. (Orgs.), Valores e comportamento nas organizações (pp. 21-55). Petrópolis: Vozes.

Schwartz, S. H. (2006). Les valeurs de base de la personne: Théorie, mesures et applications [Basic human values: Theory, measurement, and applications]. Revue Française de Sociologie, 47, 249-288.

Schwartz, S. H. (2013). National culture as value orientations: Consequences of value differences and cultural distance. In V. Ginsburgh, \& D. Throsby (Eds.), Handbook of the economics of art and culture (vol. 2, pp. 547-586). North Holland: Elsevier.

Schwartz, S. H. (no prelo). The Refined Theory of Basic Values. In S. Roccas, \& L. Sagiy (Eds.), Values and behavior: Taking a cross-cultural perspective. Springer. Retirado de https://www.researchgate.net/publication/306432422_The_Refined_Theory_of_Basic_Va lues.

Schwartz, S. H., \& Bilsky, W. (1987). Toward a universal psychological structure of human values. Journal of Personality and Social Psychology, 53, 550-62.

Schwartz, S. H., \& Bilsky, W. (1990). Toward a theory of the universal content and structure of values: Extensions and cross-cultural replications. Journal of Personality and Social Psychology, 58, 878-891.

Schwartz, S. H., \& Butenko, T. (2014). Values and behavior: Validating the refined value theory in Russia. European Journal of Social Psychology, 44(7), 799-813.

Schwartz, S. H., Cieciuch, J., Vecchione, M., Davidov, E., Fischer, R., Beierlein, C., Konty, M. (2012). Refining the theory of basic individual values. Journal of Personality and Social Psychology, 103, 663-688.

Schwartz, S. H., Cieciuch, J., Vecchione, M., Torres, C., Dirilem-Gumus, O., \& Butenko, T. (2016). Value tradeoffs and behavior in four countries: Validating 19 refined values. Manuscrito não publicado.

Seltizz, C., Wrightsman, L. S., \& Cook, S. W. (1987). Métodos de pesquisa nas relações sociais. São Paulo: EdUSP.

Semmens, N. (2007). Towards an understanding of 'Fear' as an intangible cost of crime. International Review of Victimology, 14, 219-235. 
Semyonov, M., Gorodzeisky, A., \& Glikman, A. (2012). Neighborhood ethnic composition and resident perceptions of safety in European countries. Social Problems, 59(1), 117135.

Sessar, K. (2008). Fear of crime or fear of risk? Some considerations resulting from fear of crime studies and their political implications. In H. Kury (Ed.), Fear of crime-Punitivity: New developments in theory and research (pp. 25-32). Bochum: Brockmeyer.

Shapiro, J. P., Dorman, R. L., Burkey, W. M., Welker, C. J., \& Clough, J. B. (1997). Development and factor analysis of youth attitudes toward guns and violence. Journal of Clinical Child Psychology, 26(3), 311-320.

Shapiro, J. P., Dorman, R. L., Welker, C. J., \& Clough, J. B. (1998). Youth attitudes toward guns and violence: Relations with sex, age, ethnic group, and firearm exposure. Journal of Clinical Child Psychology, 72(1), 98-108.

Shaw, C., \& McKay, H. D. (1942). Juvenile delinquency and urban areas. Chicago: University of Chicago Press.

Sibley, D. (1995). Geographies of exclusion: Society and difference in the West. London: Routledge.

Silva, B. F. A., \& Beato Filho, C. C. (2013). Ecologia social do medo: avaliando a associação entre contexto de bairro e medo de crime. Revista Brasileira de Estudos de População, 30, 155-170.

Simmons, J., \& Dodd, T. (2003). Crime in England and Wales 2002/03. Home Office Statistical Bulletin. London: Home Office.

Siqueira, S. R. (2016). Motivação para o trabalho de voluntários que atuam em hospital público estadual de São Paulo, Referência em HIV (Tese de Doutorado). Universidade de São Paulo, São Paulo.

Skogan, W. G. (1986). The Fear of Crime and its Behavioral Implications. In A. Fattah (Ed.). From Crime Policy to Victim Policy (pp. 167-190). London: Macmillan.

Skogan, W.G. (1989). Communities, crime, and neighbourhood organisation. Crime and Delinquency, 35(3), 437-457.

Skogan, W. G. (1981) Issues in the measurement of victimization. U. S. Department of Justice. Washington D. C.: U. S. Government Printing Office.

Skogan, W. G. (1983). Fear of crime in America. In America's crime problem. Testimony presented to oversight hearings before the Subcommittee on Crime of the Committee on the Judiciary, House of Representatives (Serial $n^{\circ}$. 129). Washington D. C.: US Government Printing Office.

Skogan, W. G. (1987). The impact of victimization on fear. Crime and Delinquency, 33,135154.

Skogan. W. G. (1990). Disorder and decline: Crime and the spiral of decay in american neighborhoods. New York: The Free Press. 
Skogan, W. G. (1993). The various meanings of fear. In W. Bilsky, C. Pfeiffer, \& P. Wetzels (Eds.), Fear of Crime and Criminal Victimization (pp. 131-140). Stuttgart: Enke.

Skogan, W.G. (1995). Crime and the racial fears of white americans. The Annals of The American Academy of Political and Social Science, 539, 59-71.

Skogan, W. (1999). Measuring what matters: Crime, disorder and fear. In R. Lanworthy (Ed.), Measuring what matters: Proceedings from the Policing Research Institute Meetings (pp. 37-54). Research Report. Washington D.C.: NIJ.

Skogan, W., \& Maxfield, M. (1981). Coping with crime. Beverly Hills: Sage.

Smith, L. N., \& Hill, G. D. (1991). Victimization and fear of crime. Criminal Justice and Behavior, 18(4), 217-239.

Smith, M. B., Bruner, J., \& White, R. (1956). Opinions and personality. New York: Wiley.

Smith, S.E. (1986). Fear or freedom. Illinois: Mother Courage Press.

Smith, S. J. (1985). News and the dissemination of fear. In J. Burgess, \& J. Gold (Eds.), Geography, the media and popular culture (pp. 229-253). London: Croom Helm.

Smith, S. J. (1986). Crime, space and society. Cambridge: Cambridge University Press.

Snedker, K. A. (2006). Altruistic and vicarious fear of crime: Fear for others and gendered social roles. Sociological Forum, 21(2), 163-195.

Snyder, M., \& DeBono, K. (1989). Understanding the functions of attitudes: Lessons from personality and social behavior. In A. R. Pratkains, S. J. Breckler, \& A. G. Greenwald (Eds.), Attitude structure and function (pp. 339-359). Hillsdale, NJ: Lawrence Erlbaum Associates.

Solozabal, J. R. P. (1981). Dialéctica de las actitudes en la personalidad. Ciudad de la Habana: Editorial Científico-Técnico, 1981.

Sparks, R., Genn, H., \& Dodd, D. (1977). Surveying victims: a study of the measurement of criminal victimisation, perceptions of crime, and attitudes to criminal justice. New York: Wiley.

Spielberger, C. D. (1966). Anxiety and behavior. New York: Academic Press.

Spielberger, C. D. (1972). Anxiety: Current trends in theory and research. New York: Academic Press.

Stafford, M. C., \& Galle, O. R. (1984). Victimization rates, exposure to risk, and fear of crime. Criminology, 22(2), 173-185.

Stanko, E. (1985). Intimate intrusions: Women's experience of male violence. London: Routledge and Kegan Paul.

Stanko, E. (1988). Hidden violence against women. In M. Maguire \& J. Ponting (Eds.), Victims of crime: A New Deal?(pp. 40-46). London: Open University Press. 
Stanko, E. (1990). Every day violence: How women and men experience sexual and physical danger. London: Pandora.

Stanko, E. (1997). Safety talk: Conceptualizing women's risk assessment as a "technology of the soul". Theoretical Criminology, 1, 479-499.

Sutton, R. M., \& Farrall, S. (2005). Gender, socially desirable responding and the fear of crime: Are women really more anxious about crime? British Journal of Criminology, $45(2), 212-224$.

Tabachinik, B. G., \& Fidell, L.S. (2007). Using multivariate statistics. Boston: Pearson Education, Inc.

Tamir, M., Schwartz, S. H., Cieciuch, J., Riediger, M., Torres, C., Scollon, C., Vishkin, A (2016). Desired emotions across cultures: A value-based account. Journal of Personality and Social Psychology, 111(1), 67-82.

Tartakovsky, E., \& Walsh, S. D. (2016). Testing a new theoretical model for attitudes toward immigrants: The case of social workers' attitudes toward asylum seekers in Israel. Journal of Cross-Cultural Psychology, 47(1) 72-96.

Taylor, I. (1996). Fear of crime, urban fortunes and suburban social movements: some reflections from Manchester. Sociology, 30(2), 317-337.

Taylor, I., Evans, K., \& Fraser, P. (1996). A tale of two cities: Global change, local feeling and everyday life in the North of England. London: Routledge.

Taylor, I., \& Jamieson, R. (1998). Fear of crime and fear of falling: English anxieties approaching the millennium. Archives Europeanee de Sociologie, 19(1), 149-175.

Taylor, R. (1988). Human territorial functioning: An empirical, evolutionary perspective on individual and small group territorial cognitions, behaviors, and consequences. New York: Cambridge University Press.

Taylor, R.B. (1999). The incivilities thesis: Theory, measurement, and policy. In R. Langworthy (Ed.), Measuring What Matters (pp. 65-90). Washington D.C.: NIJ.

Taylor, R. B. (2002). Fear of crime, social ties, and collective efficacy: Maybe masquerading measurement, maybe déjà vu all over again. Justice Quarterly, 19(4), 773-792.

Taylor, R., \& Hale, M. (1986). Testing alternative models of fear of crime. Journal of Criminal Law and Criminology, 77, 151-189.

Thomas, W. I., \& Znaniecki, F. (1918). The polish peasant in Europe and America. Boston: University of Chicago Press.

Thurstone, L. L. (1928). Attitudes can be measured. American Journal of Sociology, 33, 529554.

Thurstone, L. L., \& Chave, E. J. (1929). The measurement of attitude. Chicago: Chicago University Press. 
Torres, C. V., \& Allen, M. W. (2009). Human values and consumer choice in Australia and Brazil. Psicologia: Teoria e Pesquisa, 25(4), 489-97.

Torres, C. V., \& Carneiro, T. L. (2015). Atitudes. In P. F. Bendassolli \& J. E. BorgesAndrade (Orgs.). Dicionário de Psicologia do Trabalho e das Organizações (pp. 95-100). São Paulo: Casa do Psicólogo.

Torres, C. V., Schwartz, S. H., \& Nascimento, T. G. (2016). A Teoria de Valores Refinada: Associações com comportamento e evidências de validade discriminante e preditiva. Psicologia USP, 27, 341-356.

Tsai, J. L., Knutson, B., \& Fung, H. H. (2006). Cultural variation in affect valuation. Journal of Personality and Social Psychology, 90, 288-307.

Tulloch, M. (2003). Combining classificatory and discursive methods: Consistency and variability in responses to the threat of crime. British Journal of Social Psychology, 42(3), 461-476.

Tyler, T. R. (1980). Impact of directly and indirectly experienced events: The origin of crime-related judgements and behaviours. Journal of Personality and Social Psychology, 39, 13-28.

Tyler, T. R. (1984). Assessing the risk of crime victimization: The integration of personal victimization experience and socially transmitted information. Journal of Social Issues, 40, 27-38.

Tyler. T. R., \& Cook. F. L. (1984). The mass media and judgements of risk: Distinguishing impact on personal and societal level judgement. Journal of Personality and Social Psychology, 47, 693-708.

Vanderveen, G. (2006). Interpreting fear, crime, risk and unsafety. Cullompton: Willan Publishing.

Von Hentig, H. (1940). Remarks on the Interaction of Perpetrator and Victim. Journal of Criminal Law, Criminology, and Police Science, 31, 303-309.

Waiselfisz, J. J. (2016). Mapa da violência 2016: Homicídios por armas de fogo no Brasil. Rio de Janeiro: FLACSO/CEBELA.

Walklate, S. (1995). Gender and Crime: An Introduction. London: Prentice Hall/Harvester Wheatsheaf.

Walklate, S., \& Mythen, G. (2008). How scared are we? British Journal of Criminology, 48, 209-225.

Wang, H. M. (2013). Victims of crime in Taiwan. In J. Liu, S. Jou \& B. Hebenton (Eds.), Handbook of Asian Criminology (pp. 343-358). London: Springer.

Warr, M. (1984). Fear of victimization: Why are women and the elderly more afraid? Social Science Quarterly, 65, 681-702.

Warr, M. (1985). Fear of rape among urban women. Social Problems, 32(3), 238-250. 
Warr, M. (1987). Fear of victimization and sensitivity to risk. Journal of Quantitative Criminology, 3(1), 29-46.

Warr, M. (1992). Altruistic fear of victimisation in households. Social Science Quarterly, 73(4), 723-736.

Warr, M. (2000). Fear of crime in the United States: Avenues for research and policy. Criminal Justice, 4, 451-489.

Warr, M., \& Ellison, C. G. (2000). Rethinking social reactions to crime: personal and altruistic fear in family households. American Journal of Sociology, 106(3), 551-578.

Warr, M., \& Stafford, M. (1983). Fear of victimization: a look at proximate causes. Social Forces, 61, 1033-1043.

Weatherburn, D., Matka, E., \& Lind, B. (1996). Crime perception and reality: Public perceptions of the risk of criminal victimisation in Australia. Crime and Justice Bulletin, vol. 28. NSW Bureau of Crime Statistics and Research.

Wesely, J. K., \& Gaarder, E. (2004). The gendered "nature" of the urban outdoors: Women negotiating fear of violence. Gender \& Society, 18(5), 645-663.

Williams, F. P., McShane, M. D., \& Akers, R. L. (2000). Worry about victimisation: An alternative and reliable measure for fear of crime. Western Criminology Review, 2(2).

Williams Jr., R. M. (1979). Change and stability in values and value systems: A sociological perspective. In M. Rokeach (Ed.), Understanding human values individual and societal (pp. 15-46). New York: Free Press.

Wilson, J. (1975). Thinking about crime. New York: Basic Books.

Wilson. J. Q., \& Kelling, G. L. (1982). Broken windows. Atlantic Monthly, March, 29-38.

Wilson, T. D., Lindsey, S., \& Schooler, T. Y. (2000). A model of dual attitudes. Psychological Review, 107, 101-126.

Winkel, F. W., \& Vrij, A. (1990). Fear of crime and mass media crime reports: Testing similarity hypotheses. International Review of Victimology, 1, 251-265.

Wintre, M. G., North, C. \& Sugar, L. A. (2001). Psychologist's response to criticisms about research based on undergraduate participants: A developmental perspective. Canadian Psychology, 42:216-25.

Wolfgang, M. (1958). Patterns of Criminal Homicide. Philadelphia: University of Pennsylvania Press.

Wolfgang, M. E., \& Singer, S. I. (1978). Victim categories of crime. The Journal of Criminal Law and Criminology, 69(3), 379-394.

Wooldredge, J. D., Cullen, F. T., \& Latessa, E. J. (1992). Victimization in the workplace: A test of routine activities theory. Justice Quarterly, 9(2), 328-331. 
Wyant, R. B. (2008). Multilevel impacts of perceived incivilities and perceptions of crime risk on fear of crime: isolating endogenous impacts. Journal of Research in Crime and Delinquency, 45, 39-64.

Xie, J. Q. (2005). Invisible victims: An exploratory study of fear being victimization. Criminal Policy and Crime Research Collections, 8, 289-326.

Young, A. (1996). Imagining crime: Textual outlaws and criminal conversations. London: Sage.

Young, J. (1999). The exclusive society: Social exclusion, crime and difference in late modernity. London: Sage.

Young, V. (1992). Fear of victimization and victimization rates among women: A paradox? Justice Quarterly, 9, 419-441.

Zhao, J. S., Lawton B., \& Longmire, D. (2010). An examination of the micro-level crime-fear of crime link. Crime \& Delinquency, 61(1), 19-44. 


\section{Anexo}

Escala de Medo do Crime (EMC) PVQ-R e EAFAF-Compiladas

\section{Prezado(a) Participante,}

Estamos realizando uma pesquisa com o propósito de conhecer possíveis fatores contribuintes para a explicação de comportamentos sociais. Neste sentido, gostaríamos de contar com sua colaboração respondendo este questionário.

Para que você possa respondê-lo com a máxima sinceridade e liberdade, queremos lhe garantir o caráter confidencial e o sigilo de todas as suas respostas, ou seja, você não será identificado em momento algum.

Por favor, leia atentamente as instruções deste caderno e marque a resposta que mais se aproxima com o que você pensa e/ou faz, sem deixar qualquer das questões em branco.

DESDE JÁ, AGRADECEMOS SUA COLABORAÇÃO

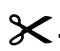

\section{TERMO DE CONSENTIMENTO LIVRE E ESCLARECIDO}

Certifico haver lido as instruções contidas nesta página, compreendo que os dados serão mantidos em sigilo, que estou participando voluntariamente e que, caso queira, poderei deixar a pesquisa a qualquer momento, sem penalização. Pela presente, dou meu consentimento para participar do estudo.

, em de de 2016.

\section{Assinatura / Rubrica do Participante}


$1^{\text {a }}$ PARTE - INSTRUÇÕES. Por favor, leia com atenção as afirmações abaixo, marcando o número de sua resposta ("1", “2”, “3”, “4” ou “5”), segundo sua concordância com o que é dito. Saiba que não existe resposta correta; interessa apenas sua opinião sincera.

1. Você carrega alguma coisa ou objeto para se defender de uma agressão física no lugar em que você mora?

\begin{tabular}{|c|c|c|c|c|}
\hline 1 & 2 & 3 & 4 & 5 \\
\hline Nunca & Muito raramente & Às vezes & $\begin{array}{c}\text { Com muita } \\
\text { frequência }\end{array}$ & Sempre \\
\hline
\end{tabular}

2. Você sentiu medo de ser seguido(a) ou ameaçado(a) na rua/quadra/setor/local em que você mora, no último mês?

\begin{tabular}{|c|c|c|c|c|}
\hline 1 & 2 & 3 & 4 & 5 \\
\hline $\begin{array}{c}\text { Nunca senti } \\
\text { medo }\end{array}$ & $\begin{array}{c}1 \text { vez no último } \\
\text { mês }\end{array}$ & $\begin{array}{c}2 \text { a } 3 \text { vezes no } \\
\text { último mês }\end{array}$ & $\begin{array}{c}2 \text { a } 3 \text { vezes na } \\
\text { última semana }\end{array}$ & Todos os dias \\
\hline
\end{tabular}

3. Qual a possibilidade de você encontrar sua casa arrombada e algo roubado de dentro dela, no próximo mês?

\begin{tabular}{|c|c|c|c|c|}
\hline 1 & 2 & 3 & 4 & 5 \\
\hline $\begin{array}{c}\text { Definitivamente } \\
\text { esse fato não vai } \\
\text { acontecer }\end{array}$ & $\begin{array}{c}\text { É pouco } \\
\text { provável que } \\
\text { esse fato } \\
\text { aconteça }\end{array}$ & $\begin{array}{c}\text { É mais ou } \\
\text { menos provável } \\
\text { que esse fato } \\
\text { aconteça }\end{array}$ & $\begin{array}{c}\text { É muito } \\
\text { provável que } \\
\text { esse fato } \\
\text { aconteça }\end{array}$ & $\begin{array}{c}\text { Certamente esse } \\
\text { fato vai } \\
\text { acontecer }\end{array}$ \\
\hline
\end{tabular}

4. Você se preocupou em ser roubado(a) ou assaltado(a) na rua/quadra/setor/local em que você mora, no último mês?

\begin{tabular}{|c|c|c|c|c|}
\hline 1 & 2 & 3 & 4 & 5 \\
\hline $\begin{array}{c}\text { Nunca me } \\
\text { preocupei }\end{array}$ & $\begin{array}{c}1 \text { vez no último } \\
\text { mês }\end{array}$ & $\begin{array}{c}2 \text { a } 3 \text { vezes no } \\
\text { último mês }\end{array}$ & $\begin{array}{c}2 \text { a } 3 \text { vezes na } \\
\text { última semana }\end{array}$ & Todos os dias \\
\hline
\end{tabular}

5. Qual a real possibilidade de alguém agredi-lo(a) fisicamente na rua/quadra/setor/local em que você mora, no próximo mês?

\begin{tabular}{|c|c|c|c|c|}
\hline 1 & 2 & 3 & 4 & 5 \\
\hline $\begin{array}{c}\text { Definitivamente } \\
\text { esse fato não vai } \\
\text { acontecer }\end{array}$ & $\begin{array}{c}\text { É pouco } \\
\text { provável que } \\
\text { esse fato } \\
\text { aconteça }\end{array}$ & $\begin{array}{c}\text { É mais ou } \\
\text { menos provável } \\
\text { que esse fato } \\
\text { aconteça }\end{array}$ & $\begin{array}{c}\text { É muito } \\
\text { provável que } \\
\text { esse fato } \\
\text { aconteça }\end{array}$ & $\begin{array}{c}\text { Certamente esse } \\
\text { fato vai } \\
\text { acontecer }\end{array}$ \\
\hline
\end{tabular}


6. O quanto você se sente capaz de evitar que seu carro seja assaltado ou roubado?

\begin{tabular}{|c|c|c|c|c|}
\hline 1 & 2 & 3 & 4 & 5 \\
\hline $\begin{array}{c}\text { Totalmente } \\
\text { incapaz }\end{array}$ & Pouco capaz & $\begin{array}{c}\text { Mais ou menos } \\
\text { capaz }\end{array}$ & Muito capaz & $\begin{array}{c}\text { Totalmente } \\
\text { capaz }\end{array}$ \\
\hline
\end{tabular}

7. Você sentiu medo de sofrer alguma violência sexual na rua/quadra/setor/local em que você mora, no último mês?

\begin{tabular}{|c|c|c|c|c|}
\hline 1 & 2 & 3 & 4 & 5 \\
\hline $\begin{array}{c}\text { Nunca senti } \\
\text { medo }\end{array}$ & $\begin{array}{c}1 \text { vez no último } \\
\text { mês }\end{array}$ & $\begin{array}{c}2 \text { a } 3 \text { vezes no } \\
\text { último mês }\end{array}$ & $\begin{array}{c}2 \text { a } 3 \text { vezes na } \\
\text { última semana }\end{array}$ & Todos os dias \\
\hline
\end{tabular}

8. O quanto você se preocupou de ter itens de seu carro roubados na rua/quadra/setor/local em que você mora, no último mês?

\begin{tabular}{|c|c|c|c|c|}
\hline 1 & 2 & 3 & 4 & 5 \\
\hline $\begin{array}{c}\text { Nunca me } \\
\text { preocupei }\end{array}$ & $\begin{array}{c}1 \text { vez no último } \\
\text { mês }\end{array}$ & $\begin{array}{c}2 \text { a } 3 \text { vezes no } \\
\text { último mês }\end{array}$ & $\begin{array}{c}2 \text { a } 3 \text { vezes na } \\
\text { última semana }\end{array}$ & Todos os dias \\
\hline
\end{tabular}

9. O quanto você se preocupa em ser vítima de sequestro-relâmpago ou rapto na rua/quadra/setor/local em que você mora, no próximo mês?

\begin{tabular}{|c|c|c|c|c|}
\hline 1 & 2 & 3 & 4 & 5 \\
\hline $\begin{array}{c}\text { Não me } \\
\text { preocupo }\end{array}$ & $\begin{array}{c}\text { Me preocupo } \\
\text { um pouco }\end{array}$ & $\begin{array}{c}\text { Me preocupo } \\
\text { mais ou menos }\end{array}$ & $\begin{array}{c}\text { Me preocupo } \\
\text { muito }\end{array}$ & $\begin{array}{c}\text { Me preocupo } \\
\text { totalmente }\end{array}$ \\
\hline
\end{tabular}

10. Com que frequência você costuma andar sozinho à noite na rua/quadra/setor/local em que você mora?

\begin{tabular}{|c|c|c|c|c|}
\hline 1 & 2 & 3 & 4 & 5 \\
\hline Nunca & Muito raramente & Às vezes & $\begin{array}{c}\text { Com muita } \\
\text { frequência }\end{array}$ & Sempre \\
\hline
\end{tabular}

11. Supondo que sua casa fosse invadida, sem você ou ninguém dentro dela, quanto você acredita que seus hábitos e comportamentos seriam modificados no futuro?

\begin{tabular}{|c|c|c|c|c|}
\hline 1 & 2 & 3 & 4 & 5 \\
\hline Nada & Pouco & Mais ou menos & Muito & Totalmente \\
\hline
\end{tabular}

12. Você acha que poderia defender-se fisicamente ou evitar o ataque de alguém que quisesse assaltá-lo(a) ou roubá-lo(a)? 


\begin{tabular}{|c|c|c|c|c|}
\hline 1 & 2 & 3 & 4 & 5 \\
\hline $\begin{array}{c}\text { Seria totalmente } \\
\text { incapaz de me } \\
\text { defender }\end{array}$ & $\begin{array}{c}\text { Seria pouco } \\
\text { capaz de me } \\
\text { defender }\end{array}$ & $\begin{array}{c}\text { Seria mais ou } \\
\text { menos capaz de } \\
\text { me defender }\end{array}$ & $\begin{array}{c}\text { Seria muito } \\
\text { capaz de me } \\
\text { defender }\end{array}$ & $\begin{array}{c}\text { Seria totalmente } \\
\text { capaz de me } \\
\text { defender }\end{array}$ \\
\hline
\end{tabular}

13. Comparada com as outras regiões administrativas (RA) do DF, você acha que o nível de criminalidade aqui na (citar a RA) é:

\begin{tabular}{|c|c|c|c|c|}
\hline 1 & 2 & 3 & 4 & 5 \\
\hline $\begin{array}{c}\text { Muito inferior } \\
\text { à média }\end{array}$ & $\begin{array}{c}\text { Um pouco } \\
\text { inferior à média }\end{array}$ & $\begin{array}{c}\text { Mais ou menos } \\
\text { a mesma média }\end{array}$ & $\begin{array}{c}\text { Um pouco } \\
\text { superior à média }\end{array}$ & $\begin{array}{c}\text { Muito superior } \\
\text { à média }\end{array}$ \\
\hline
\end{tabular}

14. Com que frequência você evita frequentar locais desertos ou eventos com poucas pessoas circulando no local (rua/quadra/setor) em que você mora?

\begin{tabular}{|c|c|c|c|c|}
\hline 1 & 2 & 3 & 4 & 5 \\
\hline Nunca & Muito raramente & Às vezes & $\begin{array}{c}\text { Com muita } \\
\text { frequência }\end{array}$ & Sempre \\
\hline
\end{tabular}

15. Qual a possibilidade de alguém tentar tomar algum pertence seu (carteira, bolsa, relógio, cordão/corrente, pulseira, ou outro similar) no transporte público que você utiliza?

\begin{tabular}{|c|c|c|c|c|}
\hline 1 & 2 & 3 & 4 & 5 \\
\hline $\begin{array}{c}\text { Totalmente } \\
\text { improvável }\end{array}$ & $\begin{array}{c}\text { Muito } \\
\text { improvável }\end{array}$ & $\begin{array}{c}\text { Mais ou menos } \\
\text { provável }\end{array}$ & Muito provável & $\begin{array}{c}\text { Totalmente } \\
\text { provável }\end{array}$ \\
\hline
\end{tabular}

16. O quanto você acha ser seguro o lugar (rua/quadra/setor/local) em que você mora?

\begin{tabular}{|c|c|c|c|c|}
\hline 1 & 2 & 3 & 4 & 5 \\
\hline $\begin{array}{c}\text { Totalmente } \\
\text { inseguro }\end{array}$ & Muito inseguro & $\begin{array}{c}\text { Mais ou menos } \\
\text { seguro }\end{array}$ & Muito seguro & $\begin{array}{c}\text { Totalmente } \\
\text { seguro }\end{array}$ \\
\hline
\end{tabular}

17. Qual a probabilidade de alguém tentar atacá-lo com arma de fogo no lugar (rua/quadra/setor/local) em que você mora?

\begin{tabular}{|c|c|c|c|c|}
\hline 1 & 2 & 3 & 4 & 5 \\
\hline $\begin{array}{c}\text { Totalmente } \\
\text { improvável }\end{array}$ & $\begin{array}{c}\text { Muito } \\
\text { improvável }\end{array}$ & $\begin{array}{c}\text { Mais ou menos } \\
\text { provável }\end{array}$ & Muito provável & $\begin{array}{c}\text { Totalmente } \\
\text { provável }\end{array}$ \\
\hline
\end{tabular}

18. O quanto você se preocupa em alguém tentar atacá-lo com arma de fogo no lugar 
(rua/quadra/setor/local) em que você mora?

\begin{tabular}{|c|c|c|c|c|}
\hline 1 & 2 & 3 & 4 & 5 \\
\hline $\begin{array}{c}\text { Não me } \\
\text { preocupo }\end{array}$ & $\begin{array}{c}\text { Me preocupo } \\
\text { um pouco }\end{array}$ & $\begin{array}{c}\text { Me preocupo } \\
\text { mais ou menos }\end{array}$ & $\begin{array}{c}\text { Me preocupo } \\
\text { muito }\end{array}$ & $\begin{array}{c}\text { Me preocupo } \\
\text { totalmente }\end{array}$ \\
\hline
\end{tabular}

19. Você costuma sair de casa portando muito dinheiro, objetos de valor ou pertences que possam chamar a atenção no lugar em que você mora?

\begin{tabular}{|c|c|c|c|c|}
\hline 1 & 2 & 3 & 4 & 5 \\
\hline Nunca & Muito raramente & Às vezes & $\begin{array}{c}\text { Com muita } \\
\text { frequência }\end{array}$ & Sempre \\
\hline
\end{tabular}


2a PARTE - CARACTERIZAÇÃO DEMOGRÁFICA. Finalmente, com o fim de conhecer um pouco mais os participantes deste estudo, pedimos-lhe que responda as perguntas a seguir. Lembramos que não temos qualquer interesse em identificá-lo. Portanto, não assine em nenhuma folha.
1. Idade: anos
2. Sexo: $\square$ Masculino
$\square$ Feminino

3. Estado Civil: $\square$ Solteiro $\square$ Casado $\square$ Separado $\square$ Outro (indique):

\section{Escolaridade:}

Não sabe ler ou escrever $\square$ Ensino Fundamental $\square$ Ensino Médio $\square$ Graduação

Especialização $\square$ Mestrado $\square$ Doutorado

5. Qual seu grau de religiosidade? (Circule um número na escala de resposta a seguir)

\begin{tabular}{|c|l|l|l|l|l|l|}
\hline $\begin{array}{c}\text { Nada } \\
\text { religioso } \\
\text { (a) }\end{array}$ & 1 & 2 & 3 & 4 & 5 & $\begin{array}{c}\text { Totalmente } \\
\text { religioso (a) }\end{array}$ \\
\hline
\end{tabular}

6. Em comparação com as pessoas da sua cidade, você diria que sua família é de qual classe socioeconômica? (Assinale um x em um dos quadros abaixo)
Baixa
$\square$ Média-Baixa
$\square$ Média
Média-Alta
Alta

7. Você já foi vítima de algum crime alguma vez?

Não

Sim... Neste caso, que crime? (descrever)

8. Você possui televisão em sua casa?

Não

Sim... Neste caso, quantas? (descrever)

9. Você assiste televisão frequentemente?
Não
$\operatorname{Sim}$

10. Em média, quantas horas de TV você assiste por semana? horas 
$\underline{3}^{\text {a }}$ PARTE - INSTRUÇÕES. Descrevemos resumidamente abaixo diferentes pessoas. Leia cada descrição e considere o quanto cada uma dessas pessoas é semelhante a você ou não.

Assinale com um "X" a opção que indica o quanto a pessoa descrita se parece com você.

\begin{tabular}{|c|c|c|c|c|c|c|}
\hline & \multicolumn{6}{|c|}{ Quanto esta pessoa se parece com você? } \\
\hline & $\begin{array}{c}\text { Não se } \\
\text { parece } \\
\text { nada } \\
\text { comigo }\end{array}$ & $\begin{array}{l}\text { Não se } \\
\text { parece } \\
\text { comigo }\end{array}$ & $\begin{array}{c}\text { Se } \\
\text { parece } \\
\text { pouco } \\
\text { comigo }\end{array}$ & $\begin{array}{c}\text { Se } \\
\text { parece } \\
\text { mais ou } \\
\text { menos } \\
\text { comigo }\end{array}$ & $\begin{array}{c}\text { Se } \\
\text { parece } \\
\text { comigo }\end{array}$ & $\begin{array}{c}\text { Se } \\
\text { parece } \\
\text { muito } \\
\text { comigo }\end{array}$ \\
\hline $\begin{array}{l}\text { 1) É importante para ela formar suas visões de maneira } \\
\text { independente. }\end{array}$ & & & & & & \\
\hline $\begin{array}{l}\text { 2) É importante para ela que seu país esteja seguro e } \\
\text { estável. }\end{array}$ & & & & & & \\
\hline 3) É importante para ela se entreter. & & & & & & \\
\hline 4) É importante para ela evitar chatear as pessoas. & & & & & & \\
\hline $\begin{array}{l}\text { 5) É importante para ela que as pessoas fracas e } \\
\text { vulneráveis da sociedade sejam protegidas. }\end{array}$ & & & & & & \\
\hline $\begin{array}{l}\text { 6) É importante para ela que as pessoas façam o que ela } \\
\text { diz que deveriam fazer. }\end{array}$ & & & & & & \\
\hline $\begin{array}{l}\text { 7) É importante para ela nunca pensar que ela merece } \\
\text { mais do que os outros. }\end{array}$ & & & & & & \\
\hline 8) É importante para ela tomar conta da natureza. & & & & & & \\
\hline $\begin{array}{l}\text { 9) É importante para ela que ninguém jamais a } \\
\text { envergonhe. }\end{array}$ & & & & & & \\
\hline $\begin{array}{l}\text { 10) É importante para ela sempre procurar coisas } \\
\text { diferentes para fazer. }\end{array}$ & & & & & & \\
\hline $\begin{array}{l}\text { 11) É importante para ela cuidar das pessoas das quais } \\
\text { ela se sente próxima. }\end{array}$ & & & & & & \\
\hline $\begin{array}{l}\text { 12) É importante para ela ter o poder que o dinheiro } \\
\text { pode trazer. }\end{array}$ & & & & & & \\
\hline $\begin{array}{l}\text { 13) É muito importante para ela evitar doenças e } \\
\text { proteger a sua saúde. }\end{array}$ & & & & & & \\
\hline $\begin{array}{l}\text { 14) É importante para ela ser tolerante com todos os } \\
\text { tipos de pessoas e grupos. }\end{array}$ & & & & & & \\
\hline $\begin{array}{l}\text { 15) É importante para ela nunca violar as regras ou } \\
\text { regulamentos. }\end{array}$ & & & & & & \\
\hline $\begin{array}{l}\text { 16) É importante para ela tomar suas próprias decisões a } \\
\text { respeito da sua vida. }\end{array}$ & & & & & & \\
\hline 17) É importante para ela ter ambições na vida. & & & & & & \\
\hline $\begin{array}{l}\text { 18) É importante para ela manter tanto os valores, } \\
\text { quanto as formas de pensar tradicionais. }\end{array}$ & & & & & & \\
\hline $\begin{array}{l}\text { 19) É Emportante para ela que as pessoas que ela } \\
\text { conhece tenham total confiança nela. }\end{array}$ & & & & & & \\
\hline 20) É importante para ela ser rica. & & & & & & \\
\hline $\begin{array}{l}\text { 21) É importante para ela tomar parte nas atividades que } \\
\text { defendam a natureza. }\end{array}$ & & & & & & \\
\hline 22) É importante para ela nunca irritar alguém. & & & & & & \\
\hline $\begin{array}{l}\text { 23) É importante para ela desenvolver suas próprias } \\
\text { opiniões. }\end{array}$ & & & & & & \\
\hline 24) É importante para ela proteger sua imagem pública. & & & & & & \\
\hline $\begin{array}{l}\text { 25) É muito importante para ela ajudar as pessoas que } \\
\text { lhe são queridas. }\end{array}$ & & & & & & \\
\hline
\end{tabular}




\begin{tabular}{|c|c|c|c|c|c|c|}
\hline & \multicolumn{6}{|c|}{ Quanto esta pessoa se parece com você? } \\
\hline & $\begin{array}{c}\text { Não se } \\
\text { parece } \\
\text { nada } \\
\text { comigo }\end{array}$ & $\begin{array}{l}\text { Não se } \\
\text { parece } \\
\text { comigo }\end{array}$ & $\begin{array}{c}\text { Se } \\
\text { parece } \\
\text { pouco } \\
\text { comigo }\end{array}$ & $\begin{array}{c}\text { Se } \\
\text { parece } \\
\text { mais ou } \\
\text { menos } \\
\text { comigo }\end{array}$ & $\begin{array}{c}\text { Se } \\
\text { parece } \\
\text { comigo }\end{array}$ & $\begin{array}{c}\text { Se } \\
\text { parece } \\
\text { muito } \\
\text { comigo }\end{array}$ \\
\hline 26) É importante para ela estar segura pessoalmente. & & & & & & \\
\hline $\begin{array}{l}\text { 27) É importante para ela ser uma amiga confiável e } \\
\text { fiel. }\end{array}$ & & & & & & \\
\hline $\begin{array}{l}\text { 28) É importante para ela assumir riscos que fazem a } \\
\text { vida ficar excitante. }\end{array}$ & & & & & & \\
\hline $\begin{array}{l}\text { 29) É importante para ela ter poder para conseguir com } \\
\text { que as pessoas façam o que ela quer. }\end{array}$ & & & & & & \\
\hline $\begin{array}{l}\text { 30) É importante para ela planejar suas atividades de } \\
\text { forma independente. }\end{array}$ & & & & & & \\
\hline $\begin{array}{l}\text { 31) É importante para ela seguir as regras mesmo se } \\
\text { ninguém estiver olhando. }\end{array}$ & & & & & & \\
\hline 32) É importante para ela ter muito sucesso. & & & & & & \\
\hline $\begin{array}{l}\text { 33) É importante para ela seguir os costumes da sua } \\
\text { família ou os costumes de uma religião. }\end{array}$ & & & & & & \\
\hline $\begin{array}{l}\text { 34) É importante para ela ouvir e compreender as } \\
\text { pessoas que são diferentes dela. }\end{array}$ & & & & & & \\
\hline $\begin{array}{l}\text { 35) É importante para ela ter um Estado forte que possa } \\
\text { defender seus cidadãos. }\end{array}$ & & & & & & \\
\hline 36) É importante para ela desfrutar dos prazeres da vida. & & & & & & \\
\hline $\begin{array}{l}\text { 37) É importante para ela que todas as pessoas no } \\
\text { mundo tenham oportunidades iguais na vida. }\end{array}$ & & & & & & \\
\hline 38) É importante para ela ser humilde. & & & & & & \\
\hline $\begin{array}{l}\text { 39) É importante para ela descobrir as coisas por si } \\
\text { mesma. }\end{array}$ & & & & & & \\
\hline $\begin{array}{l}\text { 40) É importante para ela honrar as práticas tradicionais } \\
\text { da sua cultura. }\end{array}$ & & & & & & \\
\hline $\begin{array}{l}\text { 41) É importante para ela ser a pessoa que diz aos outros } \\
\text { o que fazer. }\end{array}$ & & & & & & \\
\hline 42) É importante para ela obedecer todas as Leis. & & & & & & \\
\hline $\begin{array}{l}\text { 43) É importante para ela ter todos os tipos de } \\
\text { experiências novas. }\end{array}$ & & & & & & \\
\hline $\begin{array}{l}\text { 44) É importante para ela ter coisas caras que mostram a } \\
\text { sua riqueza. }\end{array}$ & & & & & & \\
\hline $\begin{array}{l}\text { 45) É importante para ela proteger o ambiente natural da } \\
\text { destruição ou poluição. }\end{array}$ & & & & & & \\
\hline $\begin{array}{l}\text { 46) É importante para ela aproveitar qualquer } \\
\text { oportunidade de se divertir. }\end{array}$ & & & & & & \\
\hline $\begin{array}{l}\text { 47) É importante para ela se preocupar com todas as } \\
\text { necessidades das suas pessoas queridas. }\end{array}$ & & & & & & \\
\hline $\begin{array}{l}\text { 48) É importante para ela que as pessoas reconheçam o } \\
\text { que ela alcança. }\end{array}$ & & & & & & \\
\hline 49) É importante para ela nunca ser humilhada. & & & & & & \\
\hline $\begin{array}{l}\text { 50) É importante para ela que seu país se proteja de } \\
\text { todas as ameaças. }\end{array}$ & & & & & & \\
\hline $\begin{array}{l}\text { 51) É importante para ela nunca deixar as outras pessoas } \\
\text { com raiva. }\end{array}$ & & & & & & \\
\hline $\begin{array}{l}\text { 52) É importante para ela que todos sejam tratados com } \\
\text { justiça, mesmo pessoas que ela não conhece. }\end{array}$ & & & & & & \\
\hline
\end{tabular}




\begin{tabular}{|l|l|l|l|l|l|l|}
\hline & \multicolumn{3}{|c|}{ Quanto esta pessoa se parece com você? } \\
\hline & $\begin{array}{c}\text { Não se } \\
\text { parece } \\
\text { nada } \\
\text { comigo }\end{array}$ & $\begin{array}{c}\text { Não se } \\
\text { parece } \\
\text { comigo }\end{array}$ & $\begin{array}{c}\text { Se } \\
\text { parece } \\
\text { pouco } \\
\text { comigo }\end{array}$ & $\begin{array}{c}\text { Se } \\
\text { parece } \\
\text { mais ou } \\
\text { menos } \\
\text { comigo }\end{array}$ & $\begin{array}{c}\text { Se } \\
\text { parece } \\
\text { comigo }\end{array}$ & $\begin{array}{c}\text { Se } \\
\text { parece } \\
\text { muito } \\
\text { comigo }\end{array}$ \\
\hline 53) É importante para ela evitar qualquer coisa perigosa. & & & & & & \\
\hline $\begin{array}{l}\text { 54) É importante para ela estar satisfeita com o que ela } \\
\text { tem e não querer mais. }\end{array}$ & & & & & & \\
\hline $\begin{array}{l}\text { 55) É importante para ela que todos os seus amigos e } \\
\text { família possam acreditar nela completamente. }\end{array}$ & & & & & & \\
\hline $\begin{array}{l}\text { 56) É importante para ela ser livre para escolher por ela } \\
\text { mesma o que fazer. }\end{array}$ & & & & & & \\
\hline $\begin{array}{l}\text { 57) É importante para ela aceitar as pessoas como elas } \\
\text { são, mesmo quando ela discorda delas. }\end{array}$ & & & & & & \\
\hline
\end{tabular}


$4^{\mathrm{a}}$ PARTE - INSTRUÇÕES. Por favor, leia com atenção as afirmações abaixo, assinalando ao lado de cada uma um número de 1 a 8 , segundo seu grau de acordo ou desacordo com o que é dito. Saiba que não existe resposta correta; interessa sua opinião sincera.

\begin{tabular}{|c|c|c|c|c|c|c|c|c|}
\hline AFIRMAÇÕES & $\begin{array}{l}\text { D. } \\
0 \\
0 \\
\tilde{0} \\
0 \\
0 \\
0 \\
0 \\
0 \\
.00 \\
0\end{array}$ & 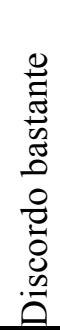 & 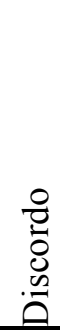 & $\begin{array}{l}0 \\
0 \\
0 \\
0 \\
\Xi \\
0 \\
0 \\
0 \\
0 \\
.00 \\
0 \\
0\end{array}$ & $\begin{array}{l}0 \\
0 \\
0 \\
0 \\
\Xi \\
0 \\
0 \\
0 \\
0 \\
0 \\
0\end{array}$ & $\begin{array}{l}0 \\
0 \\
0 \\
0 \\
0 \\
0\end{array}$ & 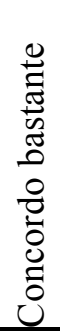 & 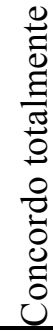 \\
\hline $\begin{array}{l}\text { 01. Muitos assassinatos não ocorreriam se uma arma } \\
\text { não estivesse disponível. }\end{array}$ & 1 & 2 & 3 & 4 & 5 & 6 & 7 & 8 \\
\hline $\begin{array}{l}\text { 02. Os criminosos não atacam as pessoas que possuem } \\
\text { armas. }\end{array}$ & 1 & 2 & 3 & 4 & 5 & 6 & 7 & 8 \\
\hline $\begin{array}{l}\text { 03. A única maneira de garantir que você } \\
\text { não será vítima de um crime é possuir uma arma de } \\
\text { fogo. }\end{array}$ & 1 & 2 & 3 & 4 & 5 & 6 & 7 & 8 \\
\hline $\begin{array}{l}\text { 04. Lojistas que têm armas de fogo em suas instalações } \\
\text { têm menor probabilidade de serem assaltados do que } \\
\text { aqueles que não têm. }\end{array}$ & 1 & 2 & 3 & 4 & 5 & 6 & 7 & 8 \\
\hline $\begin{array}{l}\text { 05. O direito de portar armas é uma liberdade } \\
\text { importante que os brasileiros deveriam assegurar. }\end{array}$ & 1 & 2 & 3 & 4 & 5 & 6 & 7 & 8 \\
\hline $\begin{array}{l}\text { 06. As pessoas deveriam poder ter armas em suas } \\
\text { casas. }\end{array}$ & 1 & 2 & 3 & 4 & 5 & 6 & 7 & 8 \\
\hline $\begin{array}{l}\text { 07. Eu deveria conseguir facilmente uma arma, se } \\
\text { quisesse ter uma. }\end{array}$ & 1 & 2 & 3 & 4 & 5 & 6 & 7 & 8 \\
\hline 08. A posse de armas é um valor básico do brasileiro. & 1 & 2 & 3 & 4 & 5 & 6 & 7 & 8 \\
\hline $\begin{array}{l}\text { 09. Pessoas cometem suicídio frequentemente devido } \\
\text { às armas de fogo estarem disponíveis. }\end{array}$ & 1 & 2 & 3 & 4 & 5 & 6 & 7 & 8 \\
\hline $\begin{array}{l}\text { 10. A proibição de possuir } \\
\text { armas representa uma violação } \\
\text { à constituição brasileira. }\end{array}$ & 1 & 2 & 3 & 4 & 5 & 6 & 7 & 8 \\
\hline $\begin{array}{l}\text { 11. As pessoas deveriam ser capazes de possuir armas, } \\
\text { porque muitas as usam para fins desportivos. }\end{array}$ & 1 & 2 & 3 & 4 & 5 & 6 & 7 & 8 \\
\hline 12. Armas estimulam a criminalidade. & 1 & 2 & 3 & 4 & 5 & 6 & 7 & 8 \\
\hline $\begin{array}{l}\text { 13. Quando você tem uma arma, pode parar de se } \\
\text { preocupar em ser vítima de crime. }\end{array}$ & 1 & 2 & 3 & 4 & 5 & 6 & 7 & 8 \\
\hline $\begin{array}{l}\text { 14. Possuir uma arma diminui as chances de } \\
\text { uma pessoa ser vítima de crime. }\end{array}$ & 1 & 2 & 3 & 4 & 5 & 6 & 7 & 8 \\
\hline $\begin{array}{l}\text { 15. Independentemente de seu potencial de lesão, é } \\
\text { direito de cada pessoa decidir ter ou não uma arma. }\end{array}$ & 1 & 2 & 3 & 4 & 5 & 6 & 7 & 8 \\
\hline $\begin{array}{l}\text { 16. O acesso fácil a armas de fogo é provável resultar } \\
\text { em um aumento da taxa de crime. }\end{array}$ & 1 & 2 & 3 & 4 & 5 & 6 & 7 & 8 \\
\hline $\begin{array}{l}\text { 17. É muito fácil matar quando se tem armas } \\
\text { disponíveis. }\end{array}$ & 1 & 2 & 3 & 4 & 5 & 6 & 7 & 8 \\
\hline
\end{tabular}

